\title{
Middle Cambrian through lowermost Ordovician conodonts from Hunan, South China
}

\author{
Xi-ping Dong ${ }^{1}$ and Huaqiao Zhang ${ }^{2}$ \\ ${ }^{1}$ School of Earth and Space Sciences, Peking University, Beijing 100871, China 〈dongxp@pku.edu.cn〉 \\ ${ }^{2}$ State Key Laboratory of Palaeobiology and Stratigraphy, Nanjing Institute of Geology and Palaeontology, Chinese Academy of Sciences, \\ Nanjing 210008, China〈hqzhang@nigpas.ac.cn〉
}

\begin{abstract}
Since 1986, samples with a total mass of more than $14,000 \mathrm{~kg}$, mainly from three key sections in western Hunan, South China, have been processed for conodonts. Previous work mainly focused on biostratigraphy, but the taxonomy has been performed only on the faunas of the middle Cambrian. Described herein are conodonts of the upper Cambrian (Furongian Series) through lowermost Ordovician from Hunan, South China. Conodonts of the middle Cambrian are redescribed, based on material that has been recovered for more than three decades. The fauna consists of 82 species belonging to 36 genera. Newly established genera are Lugnathus n. gen., Miaognathus n. gen., Millerodontus n. gen., Tujiagnathus n. gen., Wangcunella n. gen. and Wangcunognathus n. gen. New species are Coelocerodontus hunanensis n. sp., Furnishina wangcunensis n. sp., Laiwugnathus hunanensis n. sp., Laiwugnathus transitans n. sp., Lugnathus hunanensis n. gen. n. sp., Miaognathus multicostatus n. gen. n. sp., Millerodontus intermedius n. gen. n. sp., Prosagittodontus compressus n. sp., Tujiagnathus gracilis n. gen. n. sp., Wangcunella conicus n. gen. n. sp., Wangcunognathus elegans n. gen. n. sp., Westergaardodina dimorpha n. sp., Westergaardodina gigantea $\mathrm{n}$. sp., and Westergaardodina sola $\mathrm{n}$. sp. The taxonomy of some conodont genera is revised. In the light of histological investigation, genera are assigned to euconodonts, paraconodonts, or protoconodonts. The 13 conodont zones previously proposed in the middle Cambrian through lowermost Ordovician remain the same, but taxa within these conodont zones are documented more clearly because of the revised taxonomy proposed herein.
\end{abstract}

\section{Introduction}

Nogami (1966, 1967) published the first studies on Cambrian conodonts recovered from North China. An (1981, 1982) and An et al. (1983) greatly expanded systematic studies on Cambrian conodonts of northern and northeastern China. Wang (1985) and Chen and Gong (1986) focused on conodonts across the Cambrian-Ordovician boundary in northern and northeastern China. Wang and Luo (1984), An and Zheng (1990), and Zhao et al. (2000) found only sporadic Cambrian conodonts in northwestern China.

An (1982) used a more biostratigraphic approach. He made good use of the favorable geological conditions in northern and northeastern China, mainly in four key sections in Liaoning, Hebei, and Shandong. There, he founded conodont zones of the Zhangxia Formation (middle Cambrian) through the Fengshan Formation (upper Cambrian). Paraconodont zones below the Fengshan Formation were the first to be proposed for this interval anywhere in the world.

An et al. (1981) also initiated studies of Cambrian conodonts in South China, although they focused on conodonts across the Cambrian-Ordovician boundary. They found Cordylodus proavus Müller, 1959 and other important elements, such as Monocostodus sevierensis (Miller, 1969), in the dolostone in the top part of the Sanyoudong Formation in Yichang, Hubei. An et al. (1981) first proposed that the Cambrian-Ordovician boundary should be drawn at $\sim 10 \mathrm{~m}$ below the top of the Sanyoudong Formation, which previously had been considered to be entirely upper Cambrian. Dong (1983, 1985) restudied conodonts in the interval across the Cambrian-Ordovician boundary in Yichang, where he found Cordylodus intermedius Furnish, 1938 and Cordylodus angulatus Pander, 1856. Dong founded three conodont assemblage zones in these Yichang strata and proposed that the Cambrian-Ordovician boundary there should be drawn at the base of the Monocostodus sevierensis-Cordylodus intermedius Assemblage Zone, which is $14 \mathrm{~m}$ below the top of the Sanyoudong Formation in Yichang. Dong (1987) recognized the Proconodontus Zone, Cordylodus proavus Zone, and $C$. intermedius Zone in Chuxian, Anhui, South China. Based on conodonts from western Zhejiang and Chuxian, Anhui in South China, Ding et al. (1993a, b) distinguished the Proconodontus Zone and the C. proavus Zone. Western Hunan has a favorable geological setting for systematic studies of Cambrian conodonts in South China because of relatively continuous carbonate deposition, but conodont research there was in a pioneer state before the late 1980s. Xi-ping Dong began studying Cambrian through lowermost Ordovician conodont biostratigraphy and taxonomy in western Hunan in 1985. An and $\mathrm{Hu}$ (1985) and An (1987) studied two sections, namely at Luoyixi in Guzhang County and Likouzui in Fenghuang County. Because they recovered only a few Cambrian conodonts, it was not possible to propose 
conodont zones. Recently, Bagnoli and colleagues did excellent work on the Cambrian conodonts of South China (Qi et al., 2006; Bagnoli et al., 2008; Bagnoli and Qi, 2011).

One difficulty in biostratigraphic study of Cambrian conodonts has been the lack of a detailed zonation based on paraconodonts below the upper upper Cambrian. A regionally applicable zonation based on earliest euconodonts, which first appear in the upper upper Cambrian, was largely established in North America in the 1980s and has been improved subsequently (Miller et al., 2003). This zonation based on early euconodonts played an important role in delimiting the Cambrian-Ordovician boundary and should prove to be useful in defining the terminal stage of the Cambrian (Miller, 1980, 1981, 1987, 1988; Miller et al., 1982, 2006, 2011, 2014a; Forty et al., 1982; Taylor and Landing, 1982; Nowlan, 1985; Bagnoli et al., 1987; Barnes, 1988; Fåhræus and Roy, 1993; Landing, 1979, 1993; Landing and Westrop, 2006; Landing et al., 1986, 2003, 2007, 2011; Ji and Barnes, 1994; Taylor and Repetski, 1995; Nicoll et al., 1999; Parsons and Clark, 1999; Cooper et al., 2001; Pyle et al., 2007). Since 1982, several of these zones and subzones have been successively recognized in North China (An, 1982; An et al., 1983; Wang, 1985; Chen and Gong, 1986; Nowlan and Nicoll, 1995), South China (Dong, 1985, 1987; Dong et al., 2004c), Australia (Nicoll, 1990, 1991; Nicoll and Shergold, 1991), Kazakhstan (Dubinina, 2000), Mexico (Landing et al., 2007), New Zealand (Wright and Cooper, 1994), Turkey (Göncüoğlu and Kozur, 2000), and South Korea (Lee, 2001, 2002a, b, 2004, 2008a, b; Lee et al., 2009).

Despite all of this published work, conodonts in the middle Cambrian and most of the upper Cambrian have not been recognized worldwide as useful index fossils. There are several reasons for this. First, trilobites have been, and remain, the key fossils for biostratigraphic subdivision and correlation of Cambrian rocks, and most biostratigraphic studies have been centered on this group. Other groups, including conodonts, were largely neglected until the late 1960s. Second, the routine technique of etching samples with acetic acid for conodonts is suitable for processing only carbonate rocks. Conodonts are generally rare or absent in many dolostones, so only limestones are suitable in most cases for large-scale processing. However, continuously deposited and well-exposed middle Cambrian to Lower Ordovician limestone successions occur only in a few countries, such as China. Third, there has been a tendency among many conodont workers to consider the Cambrian paraconodont taxa to be stratigraphically long ranging and hence of limited use for stratigraphic subdivision and correlation.

In Europe, the well-studied middle to upper Cambrian sections in Scandinavia are stratigraphically very condensed, and the trilobite biostratigraphy has been well studied. These strata have particularly great potential for study of paraconodonts. Conodont faunas in these successions were described in a magnificent monograph by Müller and Hinz (1991). However, because the aim of their study was taxonomic rather than biostratigraphic, they focused their sampling on fossiliferous limestone nodules in the black shale succession. The age of each sample was subsequently established based on the trilobite taxa present. As a result, ranges of conodont species are known only in terms of trilobite zones, and the range of each conodont taxon within a specific trilobite zone is currently unknown unless it is present in the overlying and underlying zones. Müller and Hinz (1991) established no conodont zones, but their study suggests that many taxa are long ranging, although some of their species have restricted stratigraphic ranges (Müller and Hinz, 1991, table 2). It seems likely that their classic monograph has contributed to the belief that many paraconodonts are stratigraphically long ranging and hence of limited biostratigraphic use. In addition, several other studies in Europe and elsewhere have been mainly general or taxonomic in nature, with relatively little attention paid to the potential use of especially paraconodonts as guide fossils (Müller, 1959).

The fourth factor contributing to the lack of established Cambrian paraconodont biostratigraphy in most regions of the world is the lack of detailed research. Outside of China, there has been relatively little conodont research in strata older than the late late Cambrian, especially compared with the extensive work on euconodonts from younger rocks. For instance, many promising Cambrian sections in eastern and western North America remain unexplored for conodonts (Dong et al., 2004a). For the past 25 years, the middle and lower upper Cambrian conodont biostratigraphic work in the world has largely been centered in China, and especially in South China.

The purpose of this paper is to describe conodonts of the upper Cambrian (Furongian Series) through lowermost Ordovician from Hunan, South China and to redescribe conodonts of the middle Cambrian, based on the material that has been accumulated for the past quarter century. The taxonomy of some conodont genera is revised. In light of histological investigation, some genera can now be assigned to euconodonts, paraconodonts, or protoconodonts.

\section{Geological setting}

In terms of the paleogeography of China, the Southeast Stratigraphic Region is characterized by flyschoid sediments. In the Yangtze Stratigraphic Region, the middle and upper Cambrian succession mainly is composed of dolostone. Only in the Langyashan Subregion does the middle and upper Cambrian consist mainly of dolomitic limestone. The upper part of the middle Cambrian through the lowermost Ordovician is made up chiefly of limestone in the Danzai-Baojing-Qinyang Subregion of the Jiangnan Stratigraphic Region. Within that area, mainly in western Hunan, are well-developed and continuously deposited stratigraphic successions. Accordingly, western Hunan is an ideal area for the study of Cambrian conodonts in South China.

Three sections in Hunan were selected as key sections. These are the Paibi section in Huayuan County, the Wangcun section in Yongshun County, and Wa'ergang section in Taoyuan County. Three other sections in Hunan were selected as auxiliary sections, including the Xiaoxi section in Jishou County, the Xiaoxiqiao section in Qianzhou, and the Yangjiazhai section in Jishou. Two additional sections in Hunan were selected as reference sections; these are the Tieqiao to Liangshuijing section in Fenghuang County and the Huaqiao section in Baojing County (Fig. 1). Some of the data gathered from these investigations have been published (Dong, 1990a, b, 1991, 1992, 1993, 1997, 1999a, b, 2000, 2001; Dong and Bergström, 2000a, b, 2001a, b; Dong et al., 2001, 2004a, c). The present 

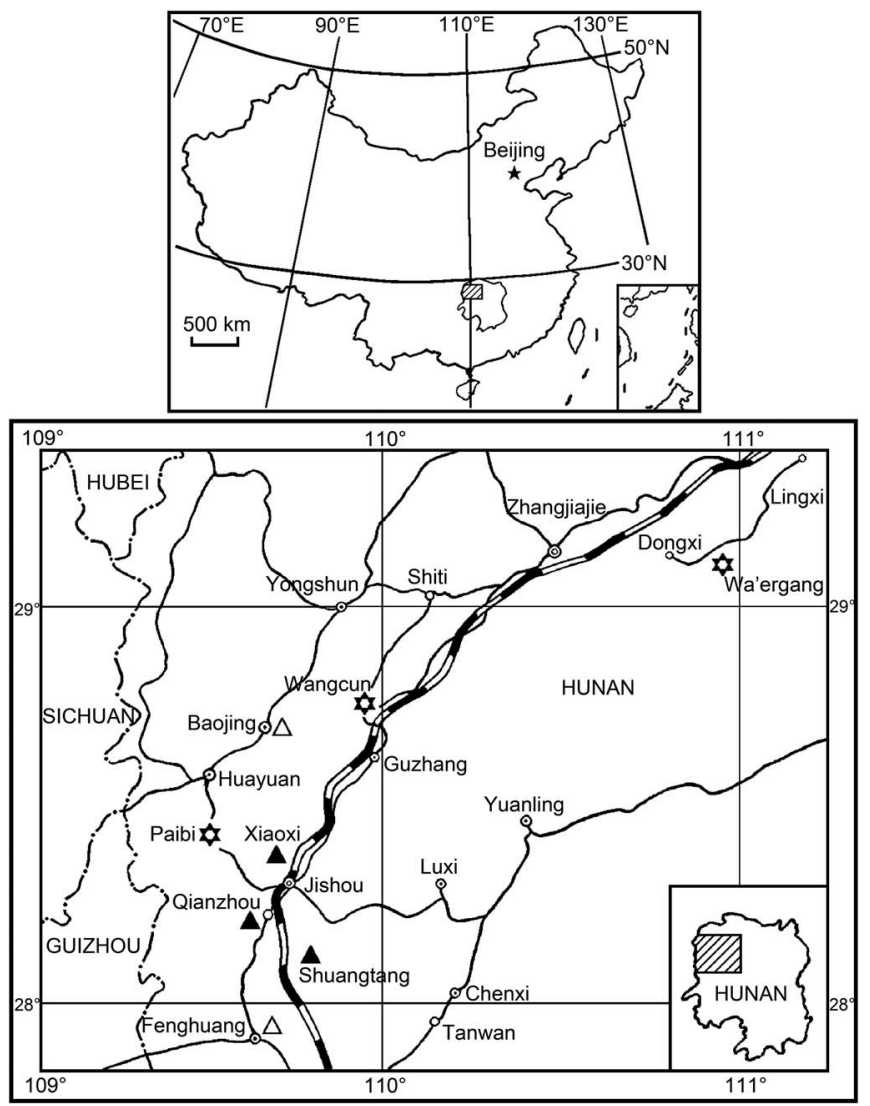

Figure 1. Location of the studied sections: Location of the key sections, $\triangle$ location of the auxiliary sections, $\triangle$ location of the reference sections.

study is the continuation of these previous studies and includes the first systematical description of the conodonts of upper Cambrian through lowermost Ordovician from Hunan, South China, taxonomic revision of some Cambrian conodonts, review of the problems in the zonation of paraconodonts recovered from western Hunan, South China, and assignment of some genera to euconodonts, paraconodonts, or protoconodonts in light of histological investigation.

Conodont samples were collected from the three key sections on 15 occasions from 1986 to 2008 and from the three auxiliary sections from 1986 to 1995 . The two reference sections were collected only sporadically, in 1986 and 1987. The average sampling interval is $2.5 \mathrm{~m}$ and the average sample mass is $4.6 \mathrm{~kg}$. A total of 3,100 conodont samples have been collected, including re-sampled ones and 388 conodont-barren samples, with a total mass of more than $14,000 \mathrm{~kg}$.

In the study area, there are mainly five types of lithology in the interval from the middle Cambrian Huaqiao Formation to the lower part of the lowermost Ordovician Panjiazui Formation.

1. Dark-gray, thin-bedded to medium- to thin-bedded, laminated, argillaceous, very fine to finely crystalline limy dolostone. Protoconodonts, but almost no other fossils, occur in this lithology.

2. Alternating layers of dark-gray, medium-bedded, laminated, argillaceous dolostone, and dark gray, medium-bedded micrite and biomicrite. The argillaceous dolostone does not yield fossils, whereas the limestones yield abundant conodonts, fossil embryos (Dong, 2007a, 2009a, b; Dong et al., 2004b, 2005a, 2010; Peng and Dong, 2008; Cheng et al., 2011), fossils of typical Orsten-type preservation (Dong et al., 2005b; Liu and Dong, 2007, 2009, 2010; Zhang and Dong, 2009; Zhang et al., 2011a, b, 2012; Duan et al., 2012), highly modified sponge spicules (Dong and Knoll, 1996; Chen and Dong, 2008), radiolarians (Dong et al., 1997), small shelly fossils (Zhu et al., 2003, 2004; Zhu and Dong, 2004), as well as trilobites and brachiopods.

3. Dark-gray, thin- to medium-bedded biomicrosparite that yields abundant conodonts as well as some trilobites, brachiopods, and bradoriids.

4. Gray, thick-bedded calcirudite. Fragmentary trilobites have been found occasionally in this lithology. No conodont samples have been collected from this lithology.

5. Dark-gray, thin-bedded micrite intercalated with dark-gray, thin-bedded to laminated, dolomitic calcisiltite, containing organic matter and scattered pyrite. Burrows and bioturbation may occur. The micrite yields abundant conodonts, as well as trilobites, brachiopods, small shelly fossils, sponge spicules, and radiolarians.

Except for type 4, the calcirudites, the other four types of lithology were collected with specific sampling intervals from the key sections and auxiliary sections on the first sampling round. Mainly type 2, type 3 , and type 5 were collected from the key sections during the second and third sampling rounds. Mainly type 3 and type 5 were collected during the fourth to the twelfth sampling rounds. The purpose of the fourth to the fifteenth sampling rounds was to recover, in addition to conodonts, sponge spicules, radiolarians, and soft-bodied fossils, such as embryos, and typical Orsten-type fossils, especially arthropods.

\section{Materials and methods}

The samples were processed by routine etching with $\sim 10 \%$ technical acetic acid in plastic pails with a capacity of $10 \mathrm{~L}$. The cycle of sieving and changing acid required 7-10 days. The samples (including duplicate samples) generally needed to be processed in three to four cycles for complete dissolution. During processing, the reaction time and the $\mathrm{pH}$ value of the solution were adjusted according to the lab temperature $\left(\sim 20^{\circ} \mathrm{C}\right.$ in winter and up to $35^{\circ} \mathrm{C}$ in July and August). Some samples were processed in plastic pails with two-layered screens to recover better specimens for histologic studies as well as for recovery of phosphatized soft-bodied fossils. Results using the two-layered screens were very good.

For histological study, protoconodont-like elements were examined by double-polished thin sections and by etching both the thin sections and artificially fractured specimens with $0.5 \%$ orthophosphoric acid for 10 minutes, and then their images were taken by scanning electron microscope. Because of the small size and thin-walled nature of these paraconodonts and earliest euconodonts, the oil immersion technique is used for those elements (Dong et al., 2005c). Clove oil was used as the immersion medium, and specimens were examined using a Zeiss Axiophot or Olympus microscope fitted with differential interference contrast (Nomarski) optics. Photomicrographs were obtained using a Nikon Coolpix 
990 or Olympus BH2 BHS UMA camera fitted via a c-mount and interchange lens to the microscope.

Repository and institutional abbreviation.-All the figured specimens are deposited at the Geological Museum, Peking University (GMPKU).

\section{Chronostratigraphy}

The Ordovician is divided into Lower, Middle, and Upper Ordovician series. The current classification of Cambrian is divided into four series; Series 2 and Series 3 have not been formally named. The Terreneuvian and Series 2 are sometimes informally referred to as lower Cambrian, Series 3 is sometimes informally referred to as middle Cambrian, and the fourth series, the Furongian Series, is sometimes referred to as upper Cambrian. Therefore, we use the term Lower Ordovician formally, but also use the terms middle Cambrian and upper Cambrian informally.

\section{Conodont biostratigraphy}

Based on the stratigraphic ranges of conodont species, the middle Cambrian through lowermost Ordovician succession at Wangcun, Wa'ergang, and Paibi, South China, is subdivided into 13 conodont zones (Figs. 2-4; see also Dong and Bergström, 2001a).

Gapparodus bisulcatus-Westergaardodina brevidens Zone.-This zone is recognized in the lower part of the middle Cambrian Huaqiao Formation in the Paibi section, Huayuan and in the Wangcun section, Yongshun. Its lower limit is marked by the First Appearance Datum (FAD) of Gapparodus bisulcatus (Müller, 1959), and its upper limit is defined by the FAD of Shandongodus priscus An, 1982. The entire zone is characterized the dominance of protoconodonts and the first occurrence and high diversity of the genus Westergaardodina Müller, 1959. The main taxa of the zone are Furnishina bigeminata Dong, 1993, F. kleithria Müller and Hinz, 1991, G. bisulcatus, Gumella cuneata Müller and Hinz, 1991, Huayuanodontus tricornis (Dong, 1993), Laiwugnathus hunanensis n. sp., Muellerodus? oelandicus (Müller, 1959), Paibiconus proarcuatus Dong, 1993, Phakelodus tenuis (Müller, 1959), Westergaardodina brevidens Dong, 1993, W. horizontalis Dong, 1993, and Yongshunella polymorpha Dong and Bergström, 2001a.

Shandongodus priscus-Hunanognathus tricuspidatus Zone.-This zone is recognized in the upper part of the middle Cambrian Huaqiao Formation in the Paibi and Wangcun sections. Its lower limit is defined by the FAD of Shandongodus priscus and its upper limit by the FAD of Westergaardodina quadrata (An, 1982). It is characterized by the extreme diversity of paraconodonts and the maximum numbers of protoconodonts. Its main taxa are Coelocerodontus bicostatus van Wamel, 1974, Furnishina cf. alata Szaniawski, 1971, F. cf. gladiata Müller and Hinz, 1991, F. cf. kranzae Müller and Hinz, 1991, F. longibasis Bednarczyk, 1979, F. pernica An, 1982, F. cf. quadrata Müller, 1959, Hunanognathus tricuspidatus Dong, 1993, Muellerodus? obliquus (An, 1982), M. pomeranensis (Szaniawski, 1971), Nogamiconus sinensis (Nogami, 1966), S. priscus, Westergaardodina elegans Dong and Bergström, 2001a, W. tetragonia Dong, 1993, and
Westergaardodina $\mathrm{sp}$. D. In addition, there are taxa ranging upward from the underlying zone, including $F$. bigeminata, Gapparodus bisulcatus, Gumella cuneata, Huayuanodontus tricornis, M.? oelandicus, Paibiconus proarcuatus, Phakelodus tenuis, W. brevidens, and Yongshunella polymorpha.

Westergaardodina quadrata Zone.-This zone can be recognized in the lower part of the middle Cambrian Chefu Formation in the Paibi and Wangcun sections. Its lower limit is defined by the FAD of Westergaardodina quadrata and its upper limit by the FAD of W. matsushitai Nogami, 1966. It is characterized by the great abundance of W. quadrata. Its main taxa are Furnishina quadrata Müller, 1959, Prosagittodontus compressus n. sp., W. cf. behrae Müller and Hinz, 1991, W. quadrata, W. cf. quadrata and W. sola n. sp. In addition, there are taxa ranging into this zone from the underlying zone, such as Furnishina cf. alata, F. bigeminata, $F$. kleithria, $F$. longibasis, $F$. pernica, $F$. cf. quadrata, Gapparodus bisulcatus, Gumella cuneata, Huayuanodontus tricornis, Hunanognathus tricuspidatus, Nogamiconus sinensis, Muellerodus? obliquus, M.? oelandicus, M. pomeranensis, Paibiconus proarcuatus, Phakelodus tenuis, W. elegans, W. tetragonia, and Yongshunella polymorpha.

Westergaardodina matsushitai-Westergaardodina grandidens Zone.-This zone can be recognized in the upper part of the middle Cambrian Chefu Formation in the Paibi, Wangcun, and Wa'ergang sections. Its base is marked by the FAD of Westergaardodina matsushitai, and its top is defined by the FAD of Westergaardodina lui Dong, Repetski, and Bergström, 2004c. It is characterized by a notable reduction in the number of protoconodonts and by the occurrence of morphologically unusual species of Westergaardodina. Its main elements are Laiwugnathus transitans n. sp., L. cf. kouzhenensis An, 1982, Prosagittodontus dahlmani (Müller, 1959), Westergaardodina cf. horizontalis Dong, 1993, W. gigantea n. sp., W. grandidens Dong, 1993, and W. matsushitai. In addition, there are taxa ranging from the underlying zone, such as Coelocerodontus bicostatus, Furnishina cf. alata, F. bigeminata, $F$. cf. kranzae, $F$. longibasis, $F$. quadrata, $F$. cf. quadrata, Gapparodus bisulcatus, Gumella cuneata, Huayuanodontus tricornis, Muellerodus? obliquus, M.? oelandicus, M. pomeranensis, Nogamiconus sinensis, Paibiconus proarcuatus, Phakelodus tenuis, Prosagittodontus compressus n. sp., W. elegans, W. cf. quadrata, W. sola n. sp., W. quadrata and Yongshunella polymorpha.

Westergaardodina lui-Westergaardodina ani Zone.-This zone occurs in the lower part of the upper Cambrian Bitiao Formation in the Wangcun and Wa'ergang sections. This zone supersedes the Westergaardodina proligula Zone as used in Dong and Bergström (2001a). Its lower boundary is defined by the FAD of $W$. lui, and its top by the FAD of $W$. cf. calix Müller and Hinz, 1991. It is characterized by a notable reduction of the diversity of species of Westergaardodina compared with strata below. Its main taxa are Furnishina dayangchaensis Chen and Gong, 1986, F. furnishi Müller, 1959, F. cf. furnishi Müller, 1959, F. gladiata Müller and Hinz, 1991, F. kranzae Müller and Hinz, 1991, F. primitiva Müller, 1959, F. tortilis (Müller, 1959), F. cf. ovata Müller and Hinz, 1991, Muellerodus cambricus (Müller, 1959), M. guttulus Müller and Hinz, 1991, Proacodus obliquus Müller, 1959, P. pulcherus (An, 1982), Prooneotodus gallatini (Müller, 1959), P. terashimai 


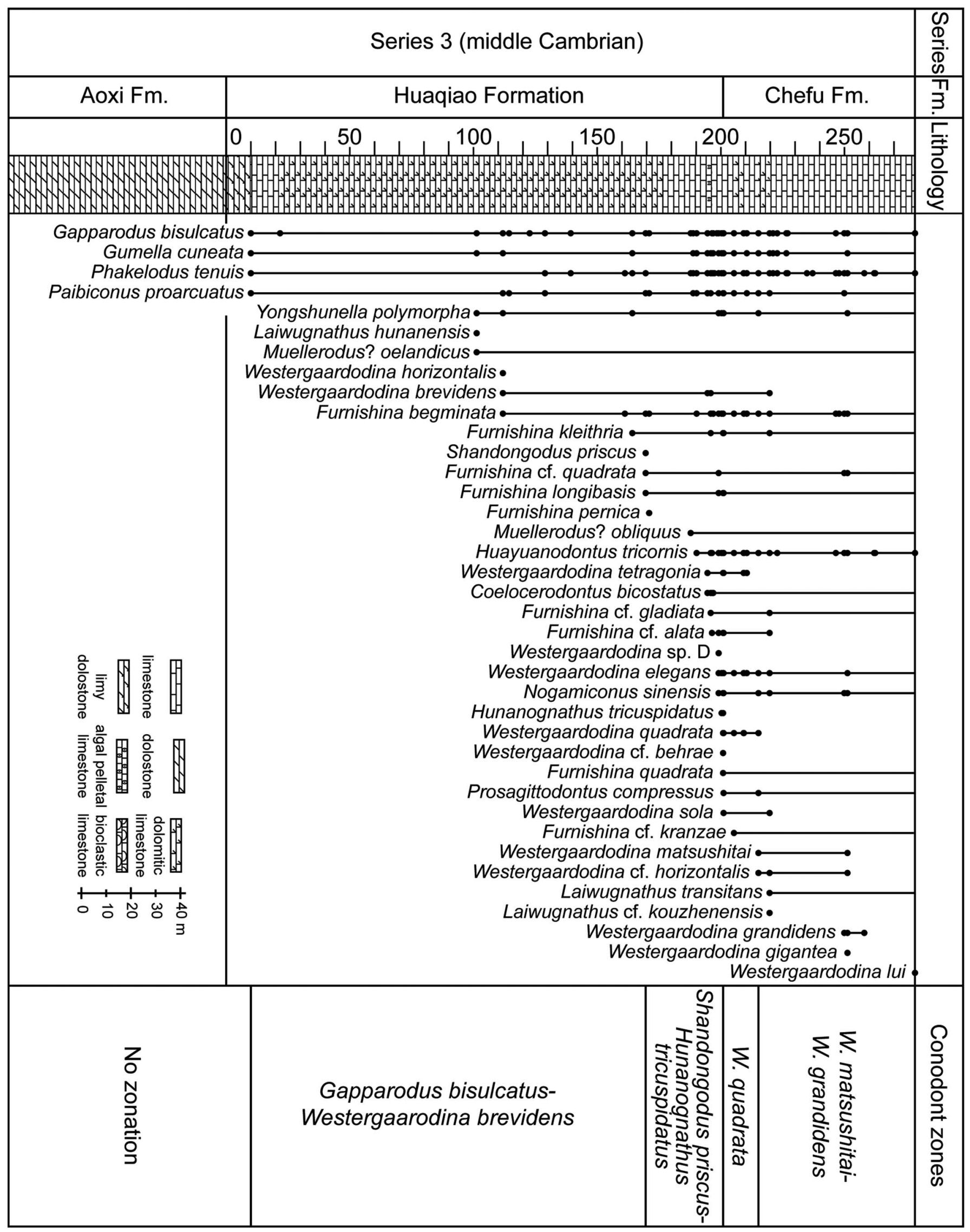

Figure 2. (Continued) 


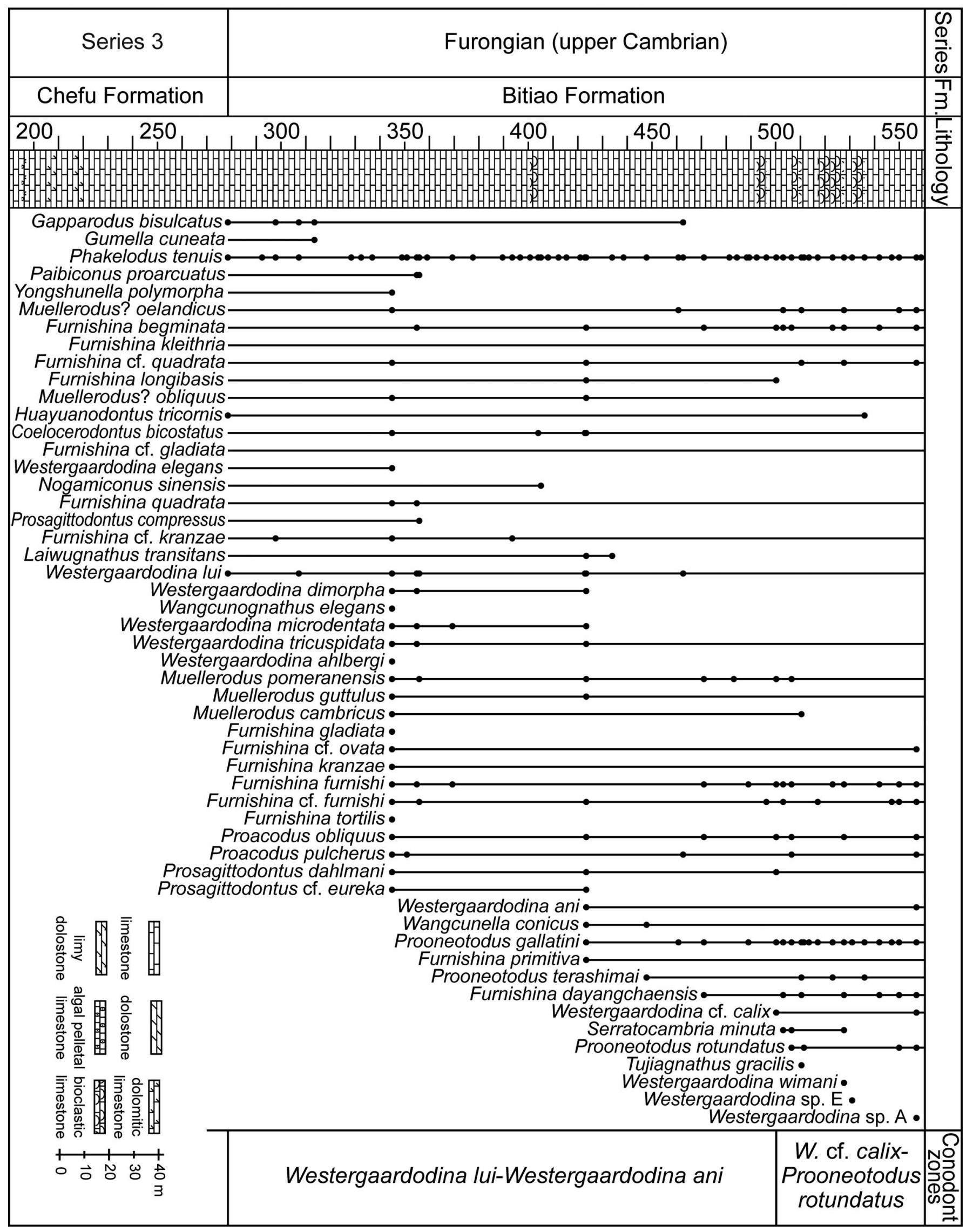

Figure 2. (Continued) 


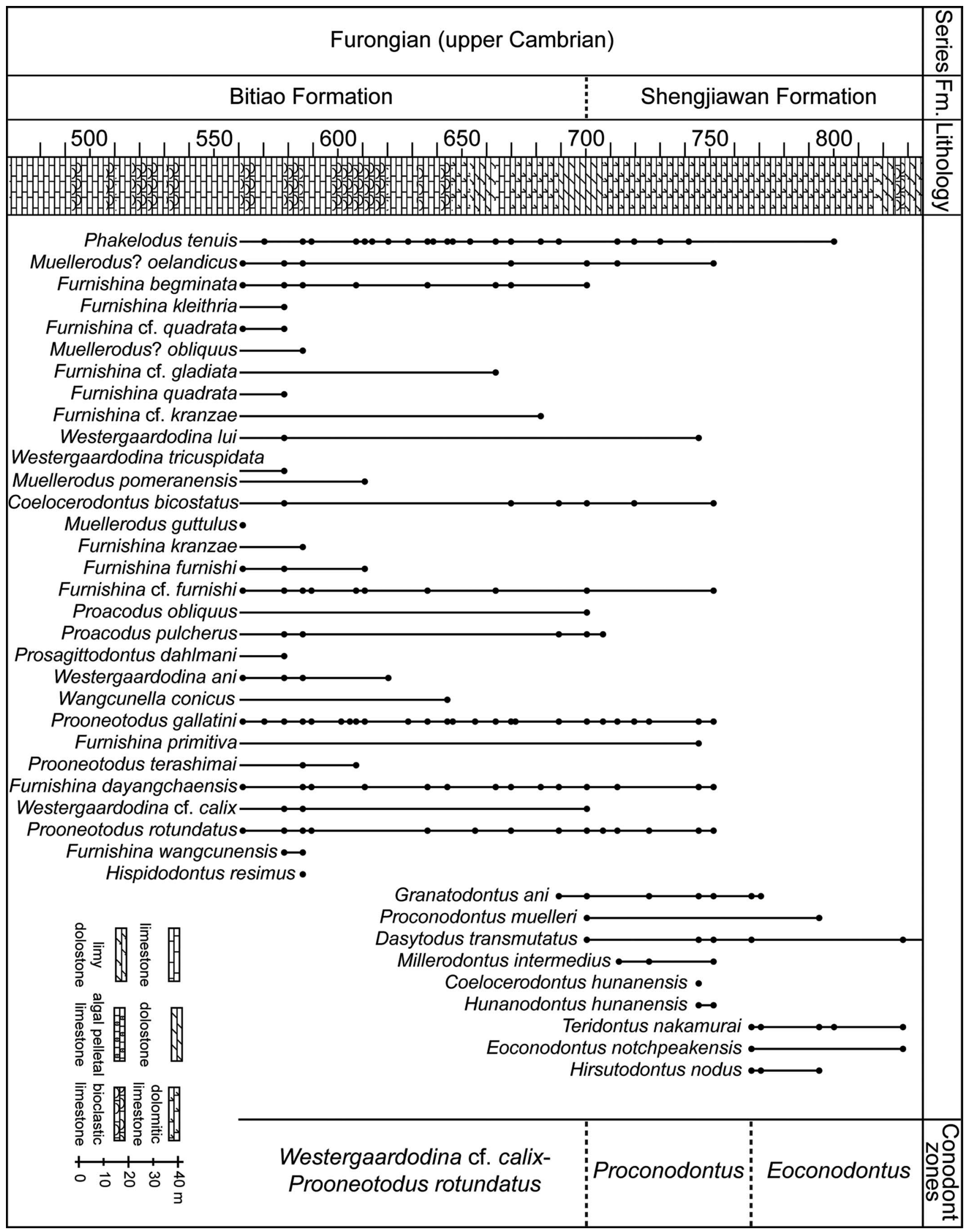

Figure 2. Chart showing the stratigraphic ranges of the upper middle Cambrian through upper Cambrian (Furongian) conodonts and conodont zones in the Wangcun section in Hunan, China. 


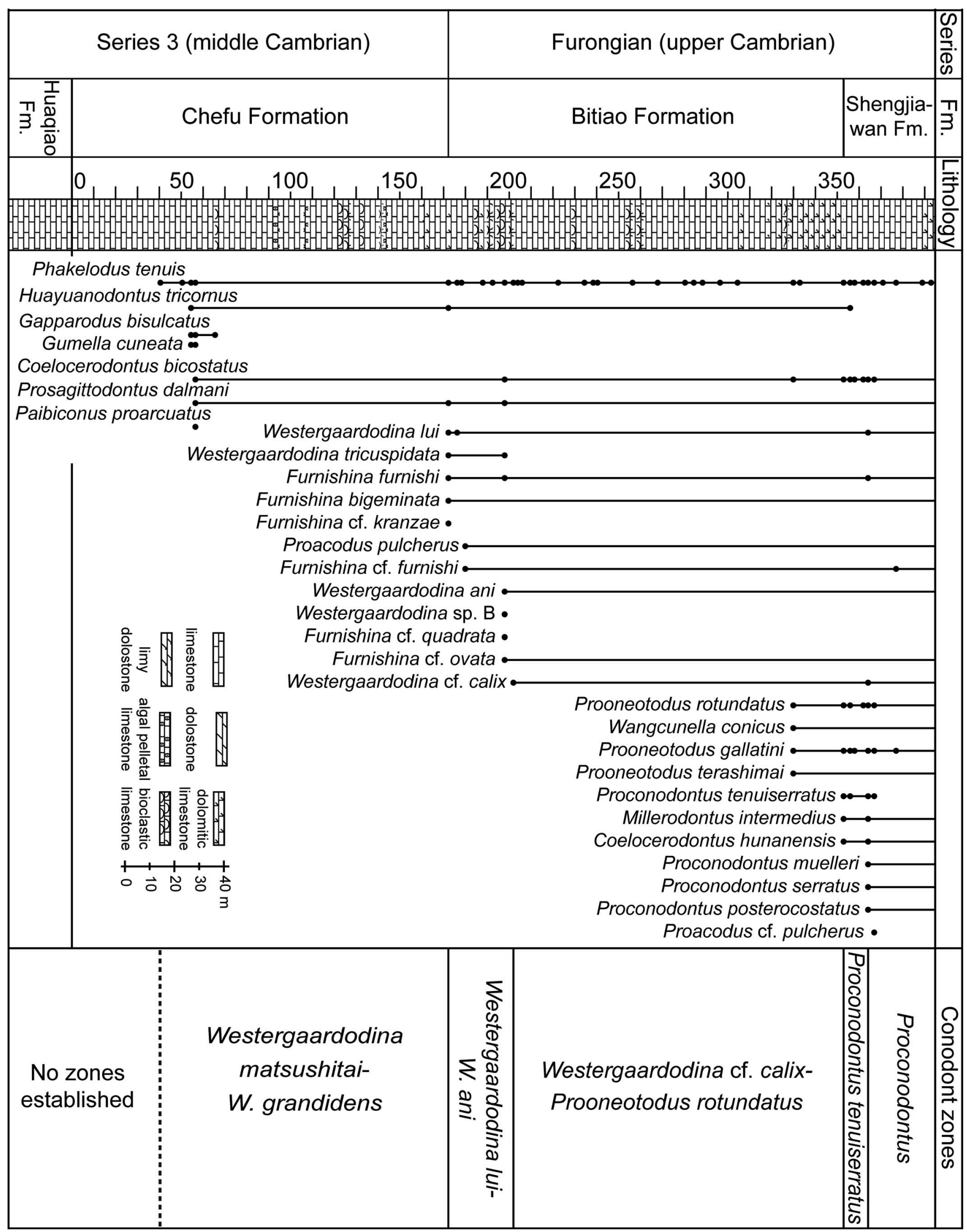

Figure 3. (Continued) 


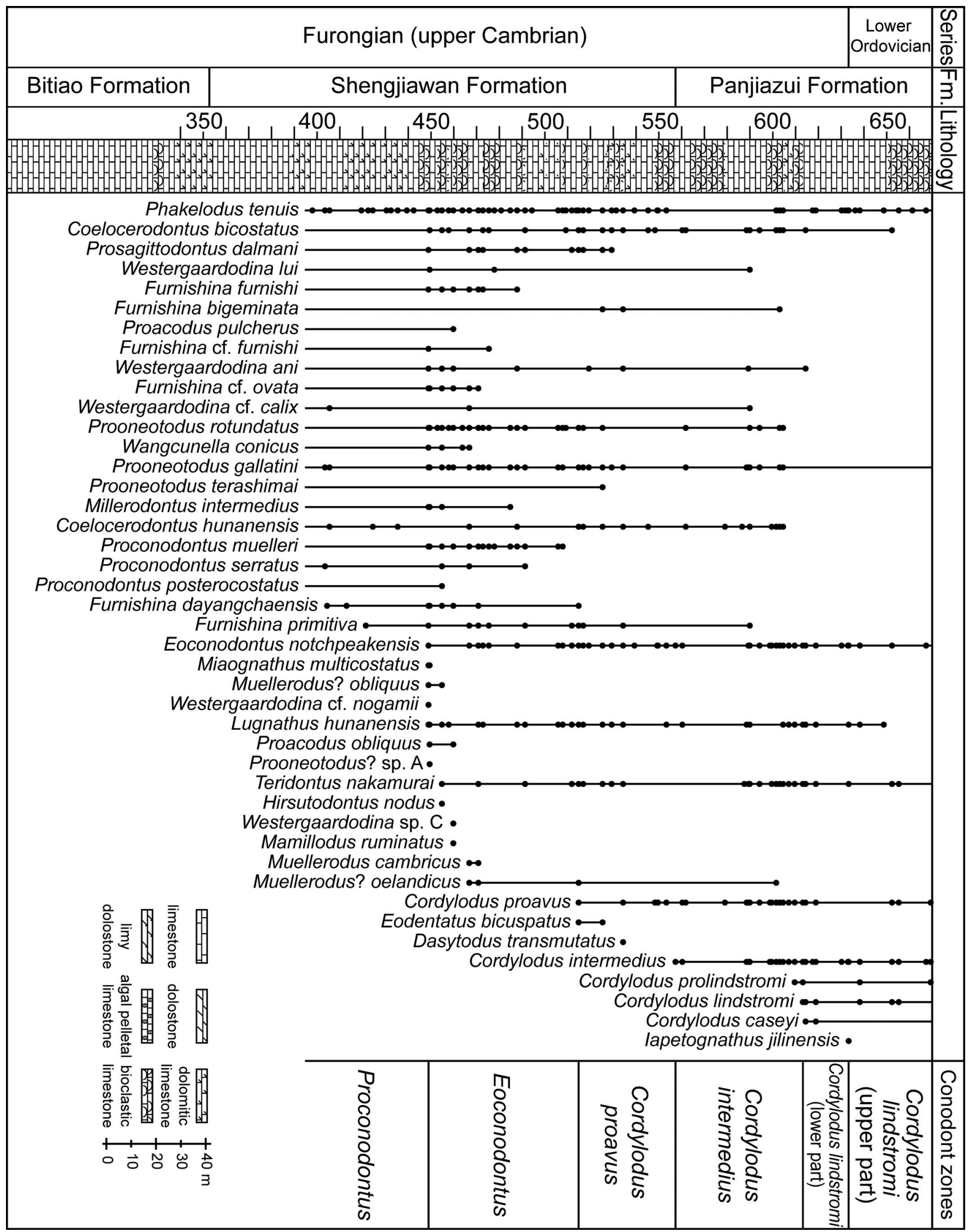

Figure 3. (Continued) 


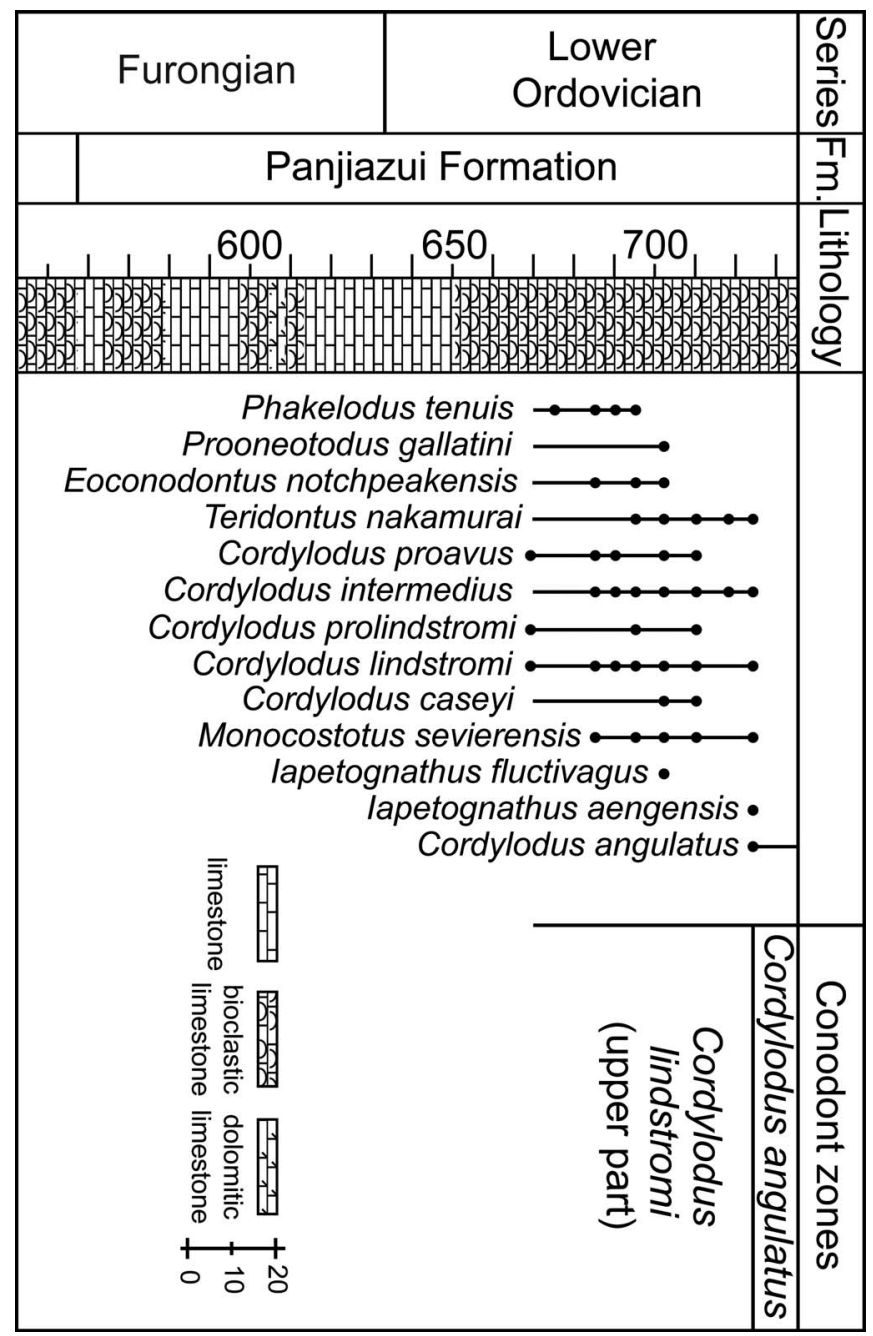

Figure 3. Chart showing the stratigraphic ranges of the upper middle Cambrian through lowermost Ordovician conodonts and conodont zones in the Wa'ergan section in Hunan, China.

(Nogami, 1967), Prosagittodontus cf. eureka Müller, 1959, Wangcunella conicus n. gen. n. sp., Wangcunognathus elegans n. gen. n. sp., Westergaardodina ahlbergi Müller and Hinz, 1991, W. ani Dong et al., 2004c, W. dimorpha n. sp., W. lui, W. microdentata Zhang in An et al., 1983, W. tricuspidata Müller, 1959, and Westergaardodina $\mathrm{sp}$. B. In addition, there are taxa that continue from the underlying zone, such as Coelocerodontus bicostatus, $F$. bigeminata, $F$. cf. kranzae, $F$. cf. gladiata, $F$. longibasis, F. quadrata, F. cf. quadrata, Gapparodus bisulcatus, Gumella cuneata, Huayuanodontus tricornis, Laiwugnathus transitans n. sp., M.? obliquus, M.? oelandicus, M. pomeranensis, Nogamiconus sinensis, Phakelodus tenuis, Prosagittodontus compressus n. sp., P. dahlmani, W. elegans, and Yongshunella polymorpha.

Westergaardodina cf. calix-Prooneotodus rotundatus Zone.-This zone is recognized in the upper part of the upper Cambrian Bitiao Formation in the Wangcun and Wa'ergang sections. This zone supercedes the Westergaardodina cf. behrae-Prooneotodus rotundatus Zone as used in Dong and Bergström (2001a). Its base is marked by the FAD of Westergaardodina cf. calix and its upper limit by the FAD of Proconodontus tenuiserratus Miller, 1980. It is characterized by the maximum number of species of Prooneotodus observed in the various zones. Its main taxa are Furnishina wangcunensis n. sp., Granatodontus ani (Wang, 1985), Hispidodontus resimus Nicoll and Shergold, 1991, Prooneotodus rotundatus (Druce and Jones, 1971), Serratocambria minuta Müller and Hinz, 1991, Tujiagnathus gracilis n. gen. n. sp., W. cf. calix, W. wimani Szaniawski, 1971, Westergaardodina sp. A., and Westergaardodina sp. E. In addition, there are taxa ranging from the underlying zone, such as Coelocerodontus bicostatus, $F$. bigeminata, $F$. dayangchaensis, $F$. furnishi, $F$. cf. furnishi, $F$. kleithria, $F$. cf. kranzae, F. cf. gladiata, F. longibasis, $F$. cf. ovata, $F$. cf. quadrata, Huayuanodontus tricornis, Muellerodus cambricus, M.? oelandicus, M. pomeranensis, M.? obliquus, Phakelodus tenuis, Proacodus obliquus, P. pulcherus, Prooneotodus terashimai, Prosagittodontus dahlmani, Wangcunella conicus n. gen. n. sp., Westergaardodina ani, W. lui, and W. tricuspidata.

Proconodontus tenuiserratus Zone.-This zone can be recognized in the lower part of the upper Cambrian Shengjiawan Formation in the Wa'ergang section. Its lower boundary is defined by the FAD of Proconodontus tenuiserratus and its upper boundary by the FAD of Proconodontus muelleri Miller, 1969. Its main taxa are Coelocerodontus hunanensis n. sp., 


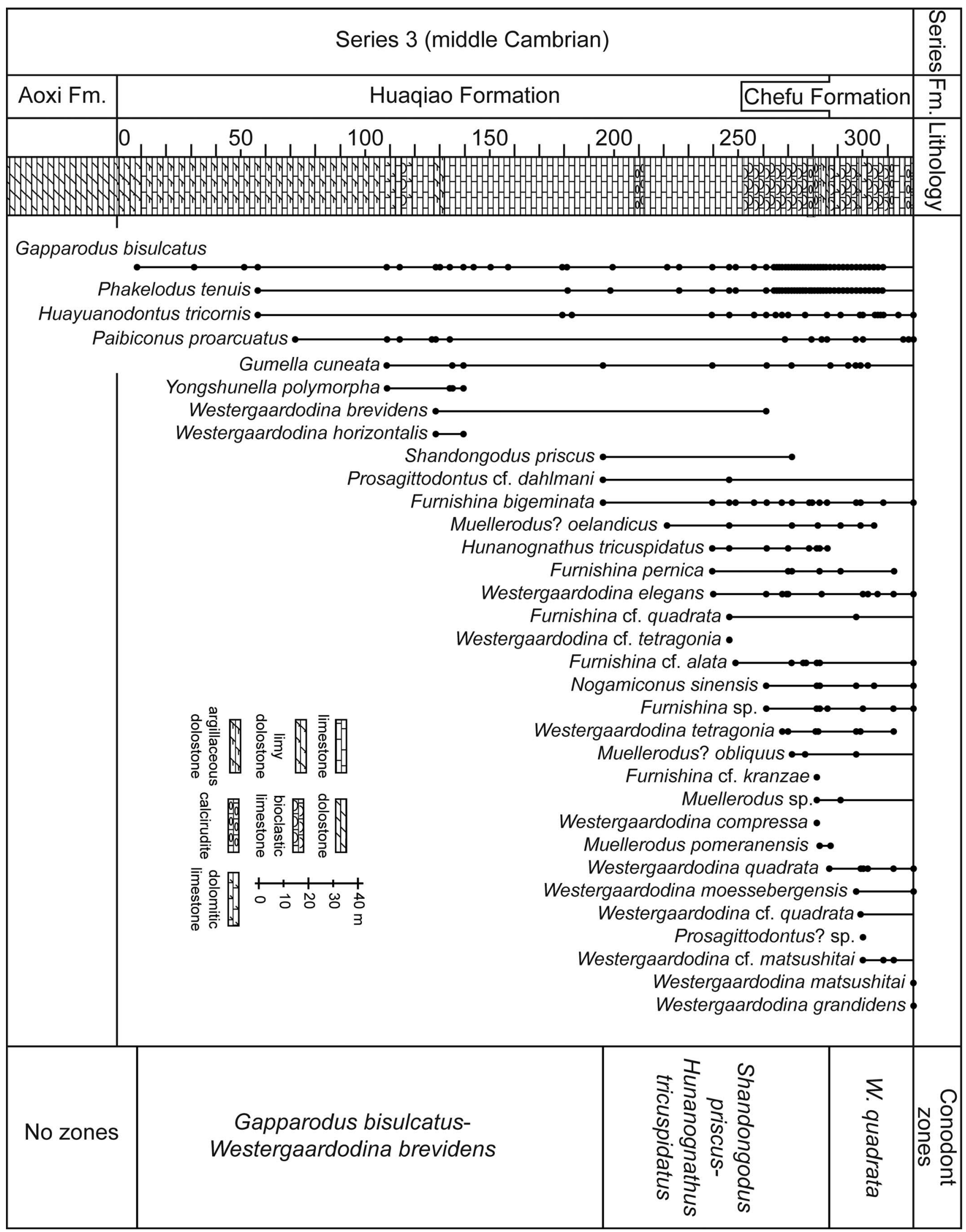

Figure 4. (Continued) 


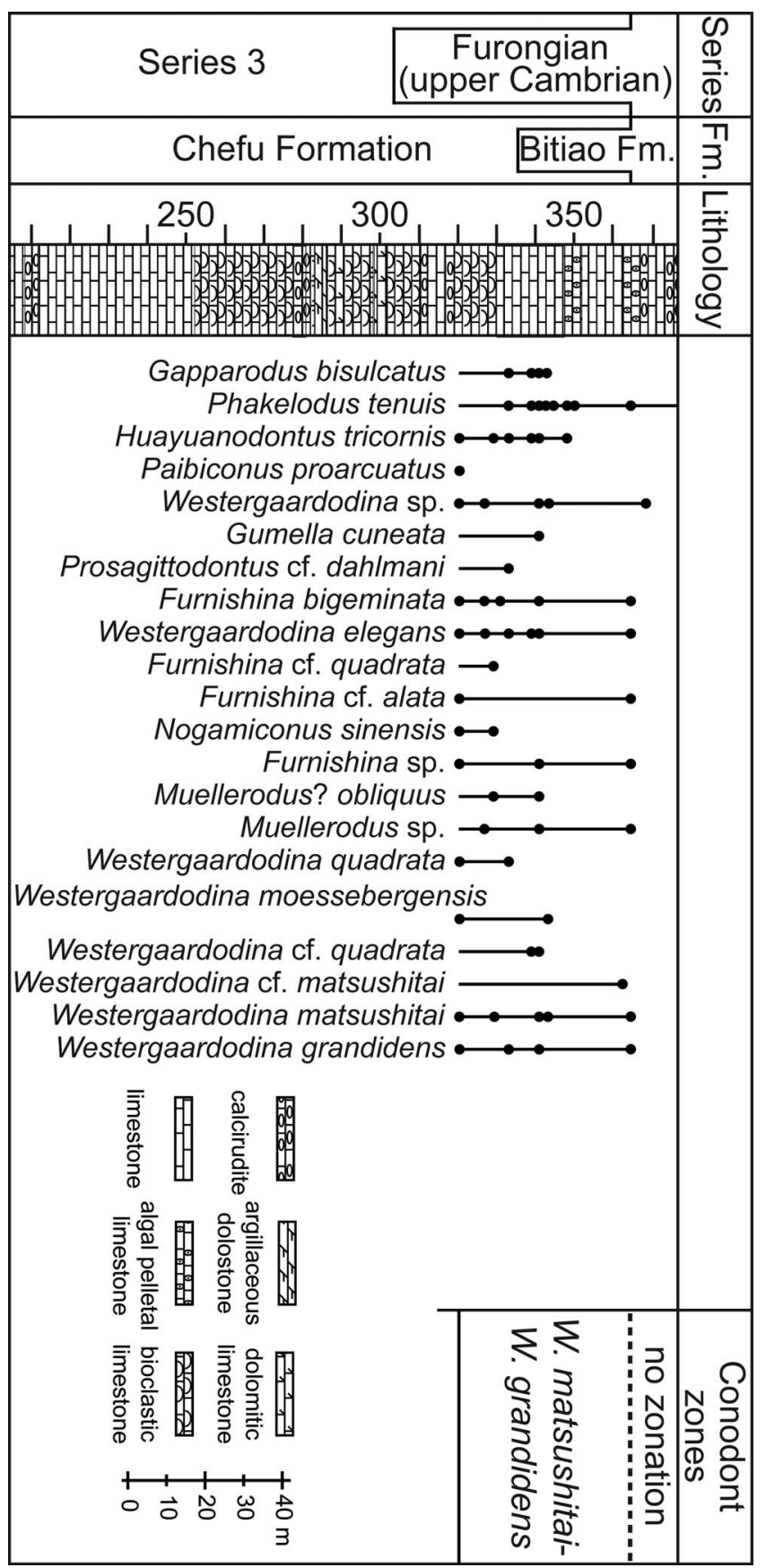

Figure 4. Chart showing the stratigraphic ranges of the upper middle Cambrian conodonts and conodont zones in the Paibi section in Hunan, China (modified after Dong and Bergström, 2001a).

Millerodontus intermedius $\mathrm{n}$. gen. n. sp., and P. tenuiserratus. In addition, there are taxa ranging from the underlying zone upward into this zone, such as Coelocerodontus bicostatus, Furnishina bigeminata, $F$. dayangchaensis, $F$. furnishi, Granatodontus ani, Huayuanodontus tricornis, Muellerodus cambricus, M.? oelandicus, Phakelodus tenuis, Proacodus obliquus, Prooneotodus gallatini, P. terashimai, P. rotundatus, Wangcunella conicus $\mathrm{n}$. gen. n. sp., Westergaardodina ani, W. lui, and W. cf. calix.

Proconodontus Zone.-This zone is recognized in the lower part of the upper Cambrian Shengjiawan Formation in the Wangcun and Wa'ergang sections. In addition, this zone can be identified in the upper Cambrian Cheshuitong Formation in Chuxian, Anhui (Dong, 1987). Its lower and upper limits are defined by the FAD of Proconodontus muelleri and Eoconodontus notchpeakensis (Miller, 1969), respectively. Its main taxa are Dasytodus transmutatus (Xu and Xiang in An et al., 1983), P. muelleri, P. posterocostatus Miller, 1980, P. serratus Miller, 1980, and Proacodus cf. pulcherus (An, 1982). In addition, there are taxa that range from the underlying zone into this zone, such as Coelocerodontus bicostatus, C. hunanensis n. sp., Furnishina bigeminata, $F$. furnishi, $F$. cf. furnishi, $F$. dayangchaensis, $F$. cf. ovata, Granatodontus ani, Millerodontus intermedius n. gen. n. sp., 
Muellerodus cambricus, M.? obliquus, M.? oelandicus, Phakelodus tenuis, Proacodus obliquus, P. pulcherus, Proconodontus tenuiserratus, Prooneotodus gallatini, P. terashimai, P. rotundatus, Prosagittodontus dahlmani, Wangcunella conicus n. gen. n. sp., Westergaardodina ani, W. lui, and W. cf. calix.

Eoconodontus Zone.-This zone can be recognized in the upper part of the upper Cambrian Shengjiawan Formation in the Wa'ergang section. Its lower and upper boundaries are defined by the FAD of Eoconodontus notchpeakensis and Cordylodus proavus, respectively. Its main taxa are E. notchpeakensis, Lugnathus hunanensis n. gen. n. sp., Hirsutodontus nodus (Zhang and Xiang, 1983), Mamillodus ruminates Dubinina, 2000, Miaognathus multicostatus n. gen. n. sp., Prooneotodus? sp. A, Teridontus nakamurai (Nogami, 1967), Westergaardodina cf. nogamii Müller Hinz, 1991, and Westergaardodina sp. C. In addition, there are taxa ranging from the underlying zone into this zone, such as Coelocerodontus bicostatus, C. hunanensis n. sp., Furnishina bigeminata, F. dayangchaensis, F. furnishi, F. cf. furnishi, $F$. primitiva, $F$. cf. ovata, Dasytodus transmutatus, Granatodontus ani, Millerodontus intermedius n. gen. n. sp., Muellerodus cambricus, M.? oelandicus, Phakelodus tenuis, Proacodus obliquus, Prooneotodus gallatini, P. terashimai, $P$. rotundatus, Proconodontus muelleri, P. posterocostatus, P. serratus, Prosagittodontus dahlmani, Wangcunella conicus n. gen. n. sp., Westergaardodina cf. calix, W. ani, and W. lui.

Cordylodus proavus Zone.-This zone is recognized in the upper part of the upper Cambrian Shengjiawan Formation in the Wa'ergang section. Moreover, this zone can be recognized in the upper Cambrian Cheshuitong Formation at Chuxian, Anhui (Dong, 1987). Its lower and upper boundaries are defined by the FAD of Cordylodus proavus and C. intermedius Furnish, 1938, respectively. Its main taxa are C. proavus and Eodentatus bicuspatus Nicoll and Shergold, 1991. In addition, there are taxa ranging from the underlying zone, such as Coelocerodontus bicostatus, C. hunanensis n. sp., Dasytodus transmutatus, Eoconodontus notchpeakensis, Furnishina bigeminata, F. furnishi, F. dayangchaensis, F. primitiva, Lugnathus hunanensis n. gen. n. sp., Muellerodus? oelandicus, Phakelodus tenuis, Prooneotodus gallatini, $P$. rotundatus, $P$. terashimai, Prosagittodontus dahlmani, Teridontus nakamurai, Westergaardodina cf. calix, W. ani, and W. lui.

Cordylodus intermedius Zone.-This zone is recognized in the lowermost part of the Panjiazui Formation in the Wa'ergang section. It can also be recognized in the lowermost part of the Cheshuitong Formation in Chuxian, Anhui (Dong, 1987); that formation originally was assigned to the Lower Ordovician. Its lower boundary is marked by the FAD of Cordylodus intermedius, and its upper boundary by the FAD of $C$. lindstromi Druce and Jones, 1971. Its main taxa are C. intermedius and C. prolindstromi Nicoll, 1991. In addition, there are taxa ranging from the underlying zone, such as Coelocerodontus bicostatus, C. hunanensis n. sp., Cordylodus proavus, Eoconodontus notchpeakensis, Furnishina primitiva, Lugnathus hunanensis n. gen. n. sp., Muellerodus? oelandicus, Phakelodus tenuis,
Prooneotodus gallatini, P. rotundatus, Teridontus nakamurai, Westergaardodina ani, W. cf. calix, and W. lui.

Cordylodus lindstromi Zone.-This zone is recognized in the lower part of the Panjiazui Formation in the Wa'ergang section. Its lower and upper boundaries are defined by the FAD of Cordylodus lindstromi and C. angulatus, respectively. Its main taxa are C. caseyi Druce and Jones, 1971, C. lindstromi, Iapetognathus fluctivagus Nicoll, Miller, Nowlan, Repetski, and Ethington, 1999, I. jilinensis Nicoll, Miller, Nowlan, Repetski, and Ethington, 1999, and Monocostodus sevierensis. Taxa that continue from the underlying zone include Coelocerodontus bicostatus, Cordylodus intermedius, C. proavus, C. prolindstromi, Eoconodontus notchpeakensis, Lugnathus hunanensis n. gen. n. sp., Phakelodus tenuis, Teridontus nakamurai, and Westergaardodina ani.

Cordylodus angulatus Zone (lower part).-This zone is recognized in the lower part of the Panjiazui Formation in the Wa'ergang section. Its lower limit is defined by the FAD of Cordylodus angulatus, but its upper limit is not delimited herein because the upper portion of this zone is beyond the scope of the present study. Its main taxa are C. angulatus and Iapetognathus aengensis (Lindström, 1955). In addition, there are taxa that range from the underlying zone, such as C. intermedius, C. lindstromi, Monocostodus sevierensis, and Teridontus nakamurai.

\section{Correlation of conodont zones}

The formal conodont zonation older than the Fengshan Formation in North China and the Shengjiawan Formation in South China (Furongian, upper Cambrian) has been mainly established in China (Figs. 5, 6). Outside China, the middle Cambrian conodont zone Gapparodus bisulcatus-Westergaadodina mossebergensis is erected in the lower part of the Machari Formation, Yeongweol area, Gangweon Province, in South Korea (Lee et al., 2009).

At present, the paraconodont zones below the Shengjiawan Formation in Hunan can be correlated only with those in North China (An, 1982; Chen and Gong, 1986). In contrast, eucondont zones in Hunan can be correlated widely with related zones in North China and elsewhere (Fig. 5).

Gapparodus bisulcatus-Westergaardodina brevidens Zone.In terms of species, this zone shares only a few elements with the Laiwugnathus laiwuensis Zone of North China (An, 1982). The upper boundary of the Hunan zone and the L. laiwuensis Zone are both marked by the FAD of Shandongodus priscus, so the top of both zones may be correlated. In Hunan, the lowest occurrence of Gapparodus bisulcatus is in the lowermost part of the middle Cambrian Huaqiao Formation, and this level is equivalent to the lowest occurrence of the trilobite Ptychagnostus atavus (Tullberg, 1880). The lowest occurrence of $P$. atavus in Hunan corresponds to that of Crepicephalina Resser and Endo in Kobayashi, 1935 in North China (Peng, 2009a). Accordingly, it is inferred that the lower part of the G. bisulcatus-Westergaardodina brevidens Zone correlates with the lower part of the Zhangxia Formation in North China (Fig. 6). 


\begin{tabular}{|c|c|c|c|c|c|}
\hline 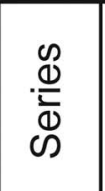 & 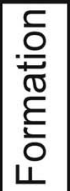 & $\begin{array}{c}\text { Hunan } \\
\text { South China } \\
\text { (Dong et al., 2004) }\end{array}$ & $\begin{array}{c}\text { North China } \\
\text { (An,1982; } \\
\text { Wang,1985; Chen } \\
\text { and Gong, 1986) }\end{array}$ & $\begin{array}{l}\text { Western U. S. A. } \\
\text { (Miller, 1980, 1988; } \\
\text { Nicoll et al., 1999) }\end{array}$ & \begin{tabular}{|} 
W. Newfoundland, \\
Canada \\
(Barnes,1988; \\
Cooper et al., 2001)
\end{tabular} \\
\hline \multirow{3}{*}{ 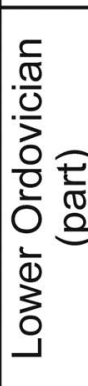 } & \multirow{5}{*}{ 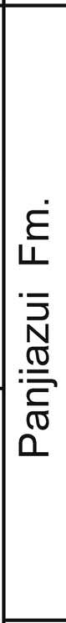 } & Above study interval & \multirow{2}{*}{$\begin{array}{c}\text { Cordylodus } \\
\text { angulatus- } \\
\text { Chosonodina } \\
\text { herfurthi }\end{array}$} & \multirow[b]{2}{*}{$\begin{array}{l}\text { Cordylodus } \\
\text { angulatus }\end{array}$} & \multirow{2}{*}{$\begin{array}{c}\text { Cordylodus } \\
\text { angulatus } \\
\text { (angulatus Fauna) }\end{array}$} \\
\hline & & $\begin{array}{l}\text { Cordylodus angulatus } \\
\text { (lower part) }\end{array}$ & & & \\
\hline & & $\begin{array}{l}\text { Cordylodus lindstromi } \\
\text { (upper part) }\end{array}$ & $\begin{array}{l}\text { Cordylodus } \\
\text { lindstromi } \\
\text { (upper part) }\end{array}$ & lapetognathus & \begin{tabular}{|c|} 
lapetognathus \\
fluctivagus \\
(lindstromi-prion- \\
lapetognathus Fauna) \\
\end{tabular} \\
\hline \multirow{9}{*}{ 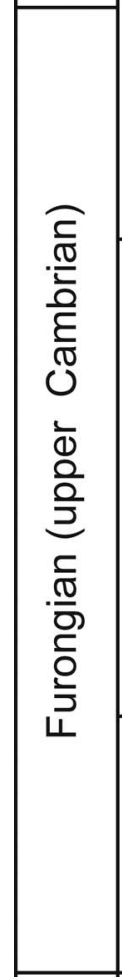 } & & $\begin{array}{l}\text { Cordylodus lindstromi } \\
\text { (lower part) }\end{array}$ & $\begin{array}{l}\text { Cordylodus } \\
\text { lindstromi } \\
\text { (lower part) }\end{array}$ & $\begin{array}{l}\text { Cordylodus } \\
\text { lindstromi } \\
\text { sensu lato } \\
\end{array}$ & $\begin{array}{l}\text { Cordylodus } \\
\text { intermedius }\end{array}$ \\
\hline & & Cordylodus intermedius & $\begin{array}{l}\text { Cordylodus } \\
\text { intermedius }\end{array}$ & $\begin{array}{l}\text { Cordylodus } \\
\text { intermedius }\end{array}$ & (intermedius Fauna) \\
\hline & \multirow{5}{*}{ 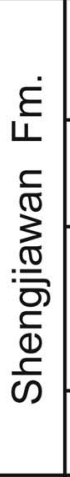 } & Cordylodus proavus & Cordylodus proavus & $\begin{array}{l}\text { Cordylodus } \\
\text { proavus }\end{array}$ & $\begin{array}{c}\text { Cordylodus proavus } \\
\text { (proavus Fauna) }\end{array}$ \\
\hline & & Eoconodontus & Cambrooistodus & Eoconodontus & $\begin{array}{c}\text { Eoconodontus } \\
\text { notchpeakensis }\end{array}$ \\
\hline & & \multirow{2}{*}{ Proconodontus } & \multirow{2}{*}{ Proconodontus } & $\begin{array}{c}\text { Proconodontus } \\
\text { muelleri }\end{array}$ & \multirow{10}{*}{$\begin{array}{l}\text { No zonation } \\
\text { established }\end{array}$} \\
\hline & & & & $\begin{array}{l}\text { Proconodontus } \\
\text { posterocostatus } \\
\end{array}$ & \\
\hline & & $\begin{array}{c}\text { Proconodontus } \\
\text { tenuiserratus }\end{array}$ & $\begin{array}{c}\text { Proconodontus } \\
\text { tenuiserratus }\end{array}$ & $\begin{array}{c}\text { Proconodontus } \\
\text { tenuiserratus }\end{array}$ & \\
\hline & \multirow{2}{*}{ 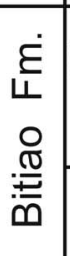 } & $\begin{array}{l}\text { Westergaardodina cf. calix- } \\
\text { Prooneotodus rotundatus }\end{array}$ & $\begin{array}{l}\text { Westergaardodina } \\
\text { aff. fossa- } \\
\text { Prooneotodus } \\
\text { rotundatus } \\
\end{array}$ & \multirow{7}{*}{$\begin{array}{l}\text { No zonation } \\
\text { established }\end{array}$} & \\
\hline & & $\begin{array}{c}\text { Westergaardodina lui- } \\
\text { W. ani }\end{array}$ & Muellerodus? erectus & & \\
\hline \multirow{5}{*}{ 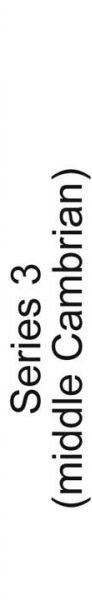 } & \multirow{2}{*}{$\begin{array}{c}\frac{\varepsilon}{4} \\
\text { पे } \\
\frac{?}{0} \\
\frac{D}{U} \\
U\end{array}$} & $\begin{array}{l}\text { W. matsushitai- } \\
\text { W. grandidens }\end{array}$ & $\begin{array}{l}\text { Westergaardodina } \\
\text { matsushitai }\end{array}$ & & \\
\hline & & $\begin{array}{c}\text { Westergaardodina } \\
\text { quadrata }\end{array}$ & $\begin{array}{c}\text { Westergaardodina } \\
\text { orygma }\end{array}$ & & \\
\hline & \multirow[b]{3}{*}{$\begin{array}{l}\frac{.}{\frac{\pi}{2}} \\
\frac{\pi}{2} \\
\frac{1}{1}\end{array}$} & $\begin{array}{c}\text { Shandongodus priscus- } \\
\text { Hunanognathus } \\
\text { tricuspidatus }\end{array}$ & $\begin{array}{l}\text { Shandongodus } \\
\text { priscus }\end{array}$ & & \\
\hline & & \multirow[b]{2}{*}{$\begin{array}{c}\text { Gapparodus bisulcatus- } \\
\text { Westergaardodina } \\
\text { brevidens }\end{array}$} & $\begin{array}{l}\text { Laiwugnathus } \\
\text { laiwuensis }\end{array}$ & & \\
\hline & & & & & \\
\hline
\end{tabular}

Figure 5. Correlation of the upper middle Cambrian through lowermost Ordovician conodont zones in Hunan, South China, and those in North China, western USA, and Newfoundland, Canada. 


\begin{tabular}{|c|c|c|c|c|c|}
\hline \multirow{4}{*}{ 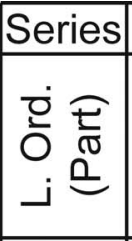 } & \multirow{4}{*}{ 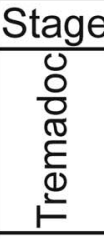 } & \multicolumn{2}{|c|}{ Formation } & \multirow{2}{*}{$\begin{array}{l}\text { Conodont Zones } \\
\text { (Dong et al., 2004) }\end{array}$} & \multirow{2}{*}{$\begin{array}{c}\text { Trilobite Zones } \\
\text { (Peng, 2009a, b; Peng et al., 2012) } \\
\end{array}$} \\
\hline & & N.China & Hunan & & \\
\hline & & \multirow{4}{*}{ 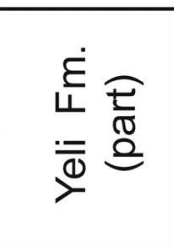 } & \multirow{4}{*}{ 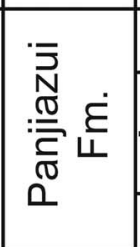 } & C. angulatus (lower part) & \multirow{4}{*}{ Hysterolenus (part) } \\
\hline & & & & C. lindstromi (upper part) & \\
\hline \multirow{13}{*}{ 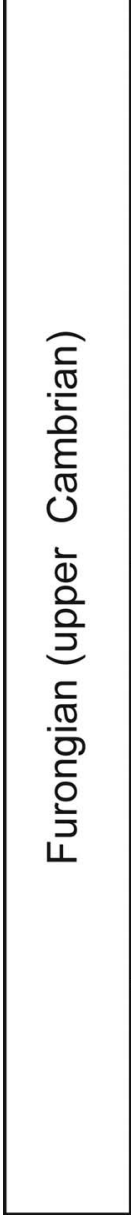 } & \multirow{6}{*}{$\begin{array}{l}\frac{0}{0} \\
\Phi \\
\frac{\pi}{0} \\
\dot{\omega}\end{array}$} & & & C. lindstromi (lower part) & \\
\hline & & & & Cordylodus intermedius & \\
\hline & & \multirow{5}{*}{ 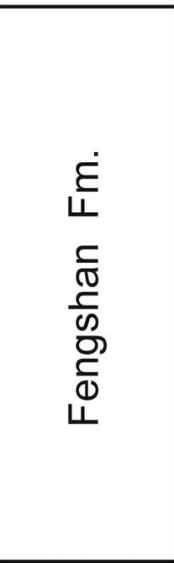 } & \multirow{5}{*}{ 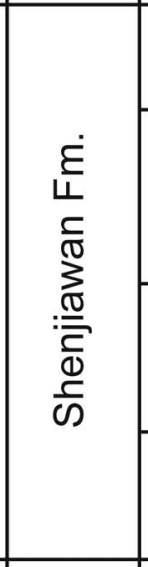 } & Cordylodus proavus & $\begin{array}{l}\text { Leiostegium constrictum- } \\
\text { Shenjiawania brevis }\end{array}$ \\
\hline & & & & & Mictosaukia striata-Fatocephalus \\
\hline & & & & Eoconodontus & $\begin{array}{l}\text { Leiagnostus cf. bexelli- } \\
\text { Archaeuloma taoyuanense }\end{array}$ \\
\hline & & & & Proconodontus & Lotagnostus americanus \\
\hline & \multirow{4}{*}{ 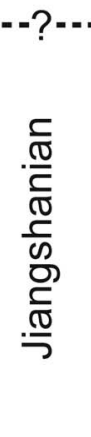 } & & & $\begin{array}{l}\text { Proconodontus } \\
\text { tenuiserratus }\end{array}$ & $\begin{array}{l}\text { Probinacunaspis nasalis- } \\
\text { Peichiashania hunanensis }\end{array}$ \\
\hline & & \multirow{6}{*}{ 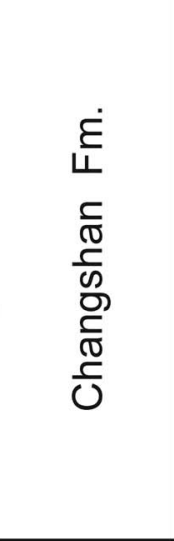 } & \multirow{6}{*}{ 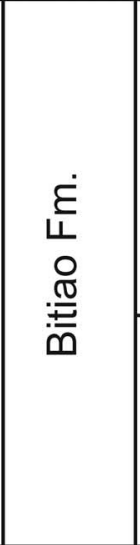 } & \multirow{3}{*}{$\begin{array}{l}\text { Westergaardodina cf. } \\
\text { calix-Prooneotodus } \\
\text { rotundatus }\end{array}$} & $\begin{array}{l}\text { Eolotagnostus decorus- } \\
\text { Kaolishaniella }\end{array}$ \\
\hline & & & & & $\begin{array}{c}\text { Rhaptagnostus ciliensis- } \\
\text { Oncholotellus cf. kuruktagnensis }\end{array}$ \\
\hline & & & & & Agnostotes orientalis \\
\hline & \multirow{3}{*}{$\frac{\sqrt{\frac{\pi}{0}}}{\frac{0}{\bar{\pi}}}$} & & & \multirow{3}{*}{$\begin{array}{l}\text { Westergaardodina } \\
\text { Iui-W. ani }\end{array}$} & $\begin{array}{l}\text { Tomagnostella orientalis- } \\
\text { Corynexochus plumula }\end{array}$ \\
\hline & & & & & $\begin{array}{l}\text { Agnostus inexpectans- } \\
\text { Proceratopyge protracta }\end{array}$ \\
\hline & & & & & Glyptagnostus reticulatus \\
\hline \multirow{9}{*}{ 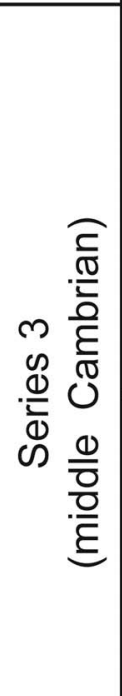 } & \multirow{5}{*}{ 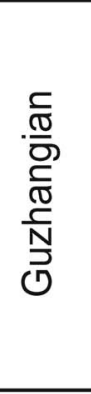 } & \multirow{3}{*}{ 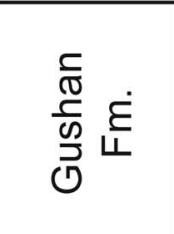 } & \multirow{3}{*}{$\begin{array}{l}\frac{\varepsilon}{4} \\
\frac{\vec{L}}{2} \\
\frac{\vec{d}}{U}\end{array}$} & \multirow{2}{*}{$\begin{array}{c}\text { Westergaardodina } \\
\text { matsushitai-W. grandidens }\end{array}$} & Glyptagnostus stolidotus \\
\hline & & & & & \multirow{2}{*}{ Linguagnostus reconditus } \\
\hline & & & & Westergaardodina quadrata & \\
\hline & & \multirow{6}{*}{ 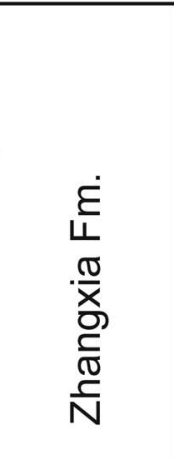 } & \multirow{6}{*}{ 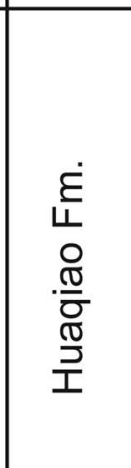 } & \multirow{2}{*}{\begin{tabular}{|c|} 
Shandongodus priscus- \\
Hunanognathus tricuspidatus
\end{tabular}} & Proagnostus bulbus \\
\hline & & & & & Lejopyge laevigata \\
\hline & \multirow{4}{*}{ 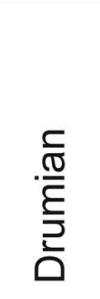 } & & & \multirow{4}{*}{$\begin{array}{c}\text { Gapparodus bisulcatus- } \\
\text { Westergaardodina brevidens }\end{array}$} & Lejopyge armata \\
\hline & & & & & Goniagnostus nathorsti \\
\hline & & & & & Ptychagnostus punctuosus \\
\hline & & & & & Ptychagnostus atavus \\
\hline
\end{tabular}

Figure 6. Correlation between the conodont zones and trilobite zones of the upper middle Cambrian through lowermost Ordovician in Hunan, South China. 
Shandongodus priscus-Hunanognathus tricuspidatus Zone.-This zone shares the zonal index species Shandongodus priscus with the $S$. priscus Zone in North China, so the two zones can be easily correlated with each other. The bases of the two zones are marked by the FAD of $S$. priscus, so the bases of these zones may be correlated. The top of the S. priscus-Hunanognathus tricuspidatus Zone in Hunan is marked by the FAD of Westergaardodina quadrata. W. quadrata and Westergaardodina orygma are associated in North China, and their FAD is at the same horizon. Accordingly, the top of the $S$. priscus-H. tricuspidatus Zone in Hunan appears to be identical to that of the $S$. priscus Zone in North China.

Westergaardodina quadrata Zone.-Westergaardodina quadrata and $W$. orygma occur together and basically have the same range in the W. orygma Zone in North China. The base of both these zones precisely corresponds with each other. Because the tops of both zones are defined by the FAD of $W$. matsushitai, these zones represent the same stratigraphic interval, and the W. quadrata Zone in South China is equivalent to the W. orygma Zone in North China.

Westergaardodina matsushitai-Westergaardodina grandidens Zone.-Westergaardodina matsushitai occurs in the W. matsushitai Zone in Hunan and in North China (An, 1982). As mentioned above, the bases of both zones are defined in the same way and hence represent the same stratigraphic level. The top of the Hunan zone is defined by the FAD of $W$. lui, which is only a few meters higher than the last occurrence of $W$. grandidens and W. matsushitai, so it is nearly identical to the top of the latter zone. Therefore, the Hunan zone is correlated with the W. matsushitai Zone in North China.

Westergaardodina lui-Westergaardodina ani Zone.-In Hunan, this zone shares only Proacodus pulcherus with the fauna of the Muellerodus? erectus Zone in North China (An, 1982; Dong and Bergström, 2001a; Dong et al., 2004c). The base of the Hunan zone is defined by the FAD of Westergaardodina lui, and the base of the North China zone is defined by the last occurrence of W. matsushitai. In Hunan, the FAD of $W$. lui is only a few meters higher than the last occurrence of W. matsushitai and W. grandidens. Accordingly, the bases of both zones are roughly coeval. The top of the Hunan zone is marked by the FAD of $W$. cf. calix, whereas the top of the North China zone is defined as the level of the last appearance of $M$. ? erectus. Precise correlation of the tops of these zones is difficult, and these zones are only approximately equivalent to each other.

Westergaardodina cf. calix-Prooneotodus rotundatus Zone.This zone shares Prooneotodus terashimai, and abundant $P$. gallatini with the Westergaardodina aff. fossa-P. rotundatus Zone in North China (An, 1982; Dong and Bergström, 2001a; Dong et al., 2004c). The bases of both zones are broadly equivalent. The tops of both these zones are marked by the FAD of Proconodontus tenuiserratus, so these zones appear to represent the same stratigraphic interval.
Proconodontus tenuiserratus Zone.-Proconodontus tenuiserratus occurs in the $P$. tenuiserratus Zone in Hunan, in the $P$. tenuiserratus Zone in North China (An, 1982; Chen and Gong, 1986), and in the western United States of America (Miller, 1988; Miller et al., 2003). Because of the rather short stratigraphic range of this species, this zone in these three regions can be approximately correlated with one another.

Proconodontus Zone.-Proconodontus muelleri and Teridontus nakamurai occur in the Proconodontus Zone in Hunan and in North China (An, 1982; Chen and Gong, 1986), and both taxa are also present in western USA (Miller, 1988; Nicoll et al., 1999; Miller et al., 2003). Because $P$. posterocostatus has been found only in two horizons in Hunan, the $P$. posterocostatus Subzone and the $P$. muelleri Subzone recognized in North China cannot be distinguished in Hunan. However, the Proconodontus Zone in Hunan roughly corresponds to the Proconodontus Zone in North China (An, 1982; Chen and Gong, 1986). The Hunan zone corresponds to the interval of both the $P$. posterocostatus Zone and the P. muelleri Zone recognized in the western USA (Miller, 1988; Miller et al., 2003).

Eoconodontus Zone.-Eoconodontus notchpeakensis occurs in the Eoconodontus Zone in Hunan and in the Cambrooistodus Zone of North China (Chen and Gong, 1986) and in the Eoconodontus Zone in the western USA (Miller, 1988; Miller et al., 2003, 2014a). In the western United States, the Eoconodontus Zone is subdivided into the E. notchpeakensis Subzone and the Cambrooistodus minutus Subzone. The correlation between these subzones and the Cambrooistodus Zone in North China (Chen and Gong, 1986) is not clear because in North China the lowest part of the range of E. notchpeakensis is within the Proconodontus Zone (Chen and Gong, 1986, text-fig. 26), and a separate Eoconodontus Zone is not recognized there. Cambrooistodus is not found in Hunan, and the Cambrooistodus Zone is only recognized at Dayangcha, North China in the warm (shallow) water realm (Miller, 1988, fig. 3). The Eoconodontus Zone in Hunan is interpreted as broadly equivalent with the Eoconodontus Zone in the western United States (Miller, 1988) and with the Cambrooistodus Zone of North China (Chen and Gong, 1986). The Eoconodontus Zone in Hunan also roughly corresponds with the E. notchpeakensis Zone in western Newfoundland, Canada (Barnes, 1988), and with the Eoconodontus Zone in Black Mountain, western Queensland, Australia (Shergold et al., 1991).

Cordylodus proavus Zone.-Cordylodus proavus occurs in the C. proavus Zone in Hunan and in the $C$. proavus Zone in North China (An, 1982; Chen and Gong, 1986), and the two zones can be correlated with each other. The base of the zone is marked by the FAD of $C$. proavus and the top by the FAD of $C$. intermedius. The $C$. proavus Zone in Hunan is also correlated with the $C$. proavus Zone in the western USA (Miller, 1980, 1988; Nicoll et al., 1999; Miller et al., 2003), and with the interval containing the proavus Fauna in western Newfoundland (Barnes, 1988; Cooper et al., 2001).

Cordylodus intermedius Zone.-This zone is recognized worldwide. In the western United States, according to Miller (1988), "the base of the Cordylodus intermedius Zone is at the 
lowest occurrence of several euconodonts (Hirsutodontus simplex, Monocostodus sevierensis, Semiacontiodus lavadamensis, Utahconus utahensis, and C. intermedius), and the paraconodont Albiconus postcostatus Miller, 1980. In some sections, all of these species begin at the same level or if one occurs below the others, it is often H. simplex." The $C$. intermedius Zone is divided into the $H$. simplex and Clavohamulus hintzei Subzones in the western United States. In the Dayangcha sections in northeastern China, the first appearance of $C$. intermedius, $H$. simplex, U. utahensis, $S$. lavadamensis, $M$. sevierensis, and $A$. postcostatus is at the same, or nearly the same, horizon, so the base of the $C$. intermedius Zone there correlates with the base of the $H$. simplex Subzone of the North American zonal scheme (Chen and Gong, 1986). However, H. simplex and C. hintzei have not yet been found in Hunan, probably because these two species were shallow water taxa. Rare specimens of these species have been found at the Green Point section, Newfoundland, but these specimens may be reworked from shallow water platform strata (Cooper et al., 2001). The precise correlation of the $C$. intermedius Zone in Hunan with the $C$. intermedius Zone in other regions is somewhat unclear. This is particularly the case with correlation of the top of the $C$. intermedius Zone in Hunan with that of the $C$. intermedius zones in other regions. Therefore, we interpret the $C$. intermedius Zone in Hunan as only roughly equivalent to the $C$. intermedius Zone in North China (Chen and Gong, 1986), the C. intermedius Zone in the western United States (Miller, 1988; Nicoll et al., 1999; Miller et al., 2003), and the interval of the intermedius Fauna in western Newfoundland (Cooper et al., 2001).

Cordylodus lindstromi Zone.-This zone is recognized widely in the world. We tentatively consider the Cordylodus lindstromi Zone in Hunan as broadly corresponding to the C. lindstromi Zone in North China (Chen and Gong, 1986). The Hunan zone corresponds to the combined Iapetognathus Zone and the Cordylodus lindstromi Zone in the western USA (Ross et al., 1997; Nicoll et al., 1999; Miller et al., 2003), and roughly to the Iapetognathus fluctivagus Zone (lindstromi-prionIapetognathus Fauna) in western Newfoundland (Cooper et al., 2001). Terfelt et al. (2012) restudied the Global boundary Stratotype Section and Point (GSSP) for the base of the Ordovician System in the Green Point section, Newfoundland, Canada. They found I. fluctivagus is not present at the boundary interval. As a result, the identification of the CambrianOrdovician boundary level outside the GSSP section has proven to be problematic. Miller et al. (2003, 2014b) suggested the base of Iapetognathus Zone should be the CambrianOrdovician boundary level, i.e., the FAD of lowest species of Iapetognathus. In Hunan, I. jilinensis Nicoll et al., 1999 is the lowest species of Iapetognathus. Consequently, the FAD of I. jilinensis is the base of the upper part of the C. lindstromi Zone and the Cambrian-Ordovician boundary level. Unfortunately, I. jilinensis has been found at only one level in Hunan, so this correlation is only approximate.

Cordylodus angulatus Zone (lower part).-Cordylodus angulatus occurs in the $C$. angulatus Zone in Hunan and in the C. angulatus-Chosonodina herfurthi Zone in North China
(Chen and Gong, 1986), in the C. angulatus Zone in the western United States (Miller, 1980, 1988; Ross et al., 1997; Nicoll et al., 1999; Miller et al., 2003), and in the interval of the angulatus Fauna in western Newfoundland (Barnes, 1988; Cooper et al., 2001). It appears that the $C$. angulatus Zone in Hunan corresponds to the lower part of the zone in the regions mentioned, and the top of this zone is above the stratigraphic interval studied herein.

\section{Correlation of conodont zones with trilobite zones}

Many workers have investigated the trilobite biostratigraphy of Cambrian sections in Hunan, e.g., Lu (1956), Jegorova et al. (1963), Lin et al. (1966), Yang (1978, 1981, 1984), Lin (1991), Dong (1990a, b, 1991), Peng (1987, 1992), Peng and Robison (2000), Peng et al. (2004), Peng (2009a, b) and Peng et al. (2012). Peng (2009a, b) and Peng et al. (2012) presented a comprehensive summary with much new information that allows detailed correlation with the Cambrian conodont zones in Hunan (Fig. 6).

\section{Conodont histology}

Although histological study on conodonts can be traced back to the 1930s (Branson and Mehl, 1933), systematic histological investigations on conodonts began in the 1970s (Müller and Nogami, 1971) and since then has been carried out by many authors (Bengtson, 1976, 1983; Szaniawski, 1982, 1983, 1987; Andres, 1988; Szaniawski and Bengtson, 1993, 1998; Müller and Hinz, 1998, etc.). The discovery of the entire conodont animal (Briggs et al., 1983; Aldridge, 1987; Aldridge et al., 1993; Gabbott et al., 1995) greatly stimulated the comparative histological study on euconodonts so as to verify their biological affinity, and many papers were involved in the "conodont controversies" (Purnell et al., 1995; Aldridge and Purnell, 1996; Donoghue et al., 2000). In contrast to the debate, Szaniawski did refined work on the affinity of protoconodonts based on their hard tissues and the fossils of chaetognaths recognized in the Burgess Shale (Szaniawski, 2002, 2005). Philip C. J. Donoghue and Xi-ping Dong investigated well-preserved elements of protoconodonts, paraconodonts, and the earliest euconodonts from the middle and late Cambrian in the Paibi, Wangcun, and Wa'ergang sections in werstern Hunan. They found that conodont elements recovered from western Hunan are of great significance in terms of histology. Our comparative histological study on the earliest euconodonts has been published (Dong et al., 2005c; Guo et al., 2005a, b), and the study on paraconodonts will be published in a separate paper.

Assignment of taxa to either protoconodonts, paraconodonts, or euconodonts is vitally important in the study of Cambrian conodonts. The present paper is only involved in the histological study as it relates to assigning taxa to one of those three groups. Bengtson (1976) proposed a model showing an evolutionary sequence from protoconodonts through paraconodonts to euconodonts. A direct evolutionary relationship between protoconodonts and paraconodonts remains unproved and is much more hypothetical than that between paraconodonts and euconodonts (Szaniawski and Bengtson, 1993; Donoghue et al., 2000; Murdock et al., 2013). At present, protoconodonts are 
assigned to phylum Chaetognatha Leuckart, 1854, whereas paraconodonts and euconodonts are assigned to different classes of phylum Chordata Bateson, 1886 (Lee et al., 2009).

Histological investigations by Philip C. J. Donoghue and Xi-ping Dong (unpublished data) indicate that it is not always possible to distinguish reliably among the elements of these three taxonomic groups based only on study of their external morphology, even by experienced observers, and histological study is often required to determine the correct taxonomy. Paibiconus Dong, 1993 and Huayuanodontus Dong and Bergström, 2001a were both considered originally to be protoconodonts (An and Mei, 1994; Dong and Bergström, 2001a). Histological investigation by Philip C. J. Donoghue and Xi-ping Dong verified that Paibiconus is a protoconodont (Dong, 2004). However, longitudinal cross sectioning of elements of Huayuanodontus showed a two-layered structure that is different from that of protoconodonts, paraconodonts, or euconodonts. Therefore, further histological work is needed to determine the taxonomic assignment of Huayuanodontus (cf. Dong, 2007b). Coelocerodontus Ethington, 1959 has thin-walled coniform elements with large basal cavities. The cross section is extremely narrow. Clusters are very common. It has been referred to as a protoconodont, paraconodont, or euconodont by different authors (Müller and Hinz, 1991, p. 53). Müller and Hinz (1991) considered it to be a euconodont, although they did not elucidate their histological evidence in 1991 or later (Müller and Hinz, 1998). Philip C. J. Donoghue and Xi-ping Dong tested many specimens of this genus recovered from Hunan by means of immersion in clove oil (unpublished data). Unequivocal crown material was found in all the tested specimens, so this genus should be considered as a euconodont.

Prooneotodus rotundatus is a cosmopolitan paraconodont species. Miller (1980) recognized a new genus and species that resembles $P$. rotundatus. He stated that the new genus and species differs from $P$. rotundatus in possessing a thin layer of apatite (crown material) that covers a massive white basal cone (Miller, 1980, p. 32). Unfortunately, he has not performed any histological investigations that he mentioned would be needed to confirm his interpretation (personal communication, J.F. Miller, 2007). We investigated well-preserved elements that appear to be $P$. rotundatus from upper Cambrian strata in Hunan, South China by means of the oil immersion technique (Dong et al., 2005c). Some of the investigated elements show typical paraconodont strucure. However, some investigated elements have crown tissues, in which we found crystals of apatite perpendicular to the conodont grown axis, and regeneration could be observed at the apical portion of the elements. Both features are typical of euconodonts, and these elements are considered euconodonts rather than paraconodonts. Herein, they are assigned to Millerodontus intermedius n. gen. n. sp., and the species is interpreted as a transition between the paraconodont Prooneotodus and the primitive euconodont genus Proconodontus. Regenerated tips of elements are found also in Proconodontus, which occurs with Millerodontus. This is the first report to establish a new conodont genus in the light of histological study.

Post-Tremadocian conodonts are all euconodonts, but protoconodonts, paraconodonts, and euconodonts co-occur in
Cambrian through Tremadocian strata. Therefore, histological investigation of Cambrian conodonts is of great importance not only in the differentiation of protoconodonts, paraconodonts, and euconodonts, but this information is the foundation on which to explore the taxonomy and the early evolution of conodonts.

\section{Systematic paleontology}

Recently, Lee et al. (2009) separated the Cambrian and Tremadocian conodnts into three groups: paraconodonts, euconodonts, and protoconodonts in their Systematic Paleontology and proposed an updated classification of conodont faunas in terms of phylum, class, and order. We follow their taxonomic treatment herein.

\section{Euconodonts}

Phylum Chordata Bateson, 1886

Superclass Conodonta Pander, 1856

Class Conodonti Branson, 1938

Genus Coelocerodontus Ethington, 1959

Type species.—Coelocerodontus trigonius Ethington, 1959.

Remarks.-This genus consists of thin-walled coniform elements with large basal cavities. The cross section is extremely narrow. Clusters are very common. As mentioned above, histological investigation indicates that it is a euconodont. It is probably the oldest known euconodont.

Coelocerodontus bicostatus van Wamel, 1974

Figures 7.1-7.12, 7.16-7.18, 8.1-8.4

1974 Coelocerodontus bicostatus van Wamel, p. 55, pl. 3, fig. 2.

1974 Coelocerodontus latus van Wamel, p. 56, pl. 1, fig. 2.

1983 "Coelocerodontus" bicostatus van Wamel; Landing, p. 1172 , fig. 10A, B.

1986 Stenodontus compressus Chen and Gong, p. 186, pl. 24 , figs. 11,16 , pl. 25 , figs. $2-5,7-13$, 16, textfig. 76.

1986 Stenodontus jilinensis Chen and Gong, p. 187, pl. 18, figs. 2, 4-7, 9, 17, 18, pl. 19, figs. 3, 7, pl. 24, figs. 1, 9, 18, pl. 34, figs. 9, 14, 15, 19, text-fig. 77.

1987 Coelocerodontus bicostatus van Wamel; An, p. 104, pl. 1, fig. 11.

1987 Diaphanodus latus (van Wamel); Bagnoli et al., p. 155, pl. 2, figs. 11, 12.

1988 Coelocerodontus cambricus (Nogami); Heredia and Bordonaro, p. 190, pl. 2, figs. 2, 3.

1988 Rotundoconus mendozanus Heredia and Bordonaro, p. 194, pl. 3, fig. 5, pl. 4, fig. 3.

1988 Coelocerodontus cambricus (Nogami); Lee and Lee, pl. 1, fig. 27.

1988 Coelocerodontus apparatus, Andres, pl. 9, figs. 3-8, text-fig. 19. 
1991 Coelocerodontus bicostatus van Wamel; Müller and Hinz, p. 53, pl. 41, figs. 1-21, text-figs. 20A-D.

2000 “Proacontiodus" latus entis Dubinina, p. 175, pl. 3, figs. 15, 16, 20, 21 (not figs. 1, 1a, 7, 8).

2000 "Proacontiodus"latus Dubinina, p. 174, pl. 3, figs. 30, 31.

2001 Coelocerodontus cambricus (Nogami); Lee, p. 449, figs. 6, 11.

2002a Coelocerodontus cambricus (Nogami); Lee, p. 165, pl. 2, fig. 16.

2002b Coelocerodontus cambricus (Nogami); Lee, p. 25, pl. 1, figs. 16, 17.

? 2006 Coelocerodontus bicostatus van Wamel; Qi et al., p. 187, pl. 3, fig. 17.

2007 Coelocerodontus bicostatus van Wamel; Landing et al., p. 922, fig. 9a, b.

2009 Coelocerodontus bicostatus van Wamel; Lee et al., p. 423, figs. 7, 18 .

2011 Coelocerodontus bicostatus van Wamel; Bagnoli and Qi, p. 12 (G, H, I).

2014 Stenodontus compressus Chen and Gong; Bagnoli and Stouge, p. 20, fig. 11, N-R.

Description.-Bimembrate apparatus of asymmetrical and subsymmetrical elements. The asymmetrical element is thinwalled and coniform. It is laterally compressed, with keeled anterior and posterior edges. Its cross section is extremely narrow. Both lateral sides have a costa that extends up to the apex. The pointed apex extends far beyond the posterior basal margin, leading to a recurved triangular outline in lateral view. The basal cavity is very deep. The subsymmetrical element differs from the asymmetrical element in the hook-like apical portion and the inconspicuous carinae instead of costae on both lateral sides.

Materials.—469 specimens.

Occurrence.-Known from the Wangcun and Wa'ergang sections, where it ranges from the Shandongodus priscus-Hunanognathus tricuspidatus Zone through the Cordylodus intermedius Zone.

Remarks.-Müller and Hinz (1991) described Morphotype alpha and Morphotype beta of this species. Of the material at hand, the asymmetrical element and subsymmetrical element correspond, respectively, with Morphotype alpha and Morphotype beta in terms of overall morphology.

Coelocerodontus hunanensis new species

Figures 7.13-7.15, 7.19-7.25, 9.1-9.14, 9.18, 9.19

Diagnosis.-Elongate proclined, thin-walled coniform elements with very deep basal cavities, laterally compressed, with keeled anterior and posterior edges. Both lateral sides are characterized by costae or only one lateral side is characterized by a costa. The outline is extremely slender, with a high length/maximum width ratio.

Description.-Elongate, thin-walled coniform elements, proclined, asymmetrical, laterally compressed, with keeled anterior and posterior edges. The cross section is extremely narrow. Both lateral sides are characterized by costae or only one lateral side is characterized by a costa, each of which extends up to the apex; position of these costae is highly variable. The outline of the element is extremely slender. The length/maximum width ratio is more than 3.5. The tip of the cusp is usually not preserved. The basal cavity is very deep.

Etymology.- - Named for its provenance in Hunan Province.

Types.-Holotype: GMPKU2432, from the Cordylodus intermedius Zone, Furongian (upper Cambrian), Panjiazui Formation, Wa'ergang section, Wa'ergang village, Taoyuan County, Hunan Province.

Materials._-368 specimens.

Occurrence.-Known from Wangcun and Wa'ergang sections, where it ranges from the Proconodontus tenuiserratus Zone through the Cordylodus intermedius Zone.

Remarks.-It differs from Coelocerodontus bicostatus in its much more slender outline and much higher length/maximum width ratio.

Genus Cordylodus Pander, 1856

Type species.-Cordylodus angulatus Pander, 1856.

Remarks.-Most species of this genus are cosmopolitan in distribution and are of great significance in biostratigraphy and the evolution of early euconodonts. There has never been a consensus on their apparatus reconstruction. Miller (1980) established a two-element apparatus of this genus, and he identified them as rounded and compressed elements based on the cross section of the cusp. This interpretation was accepted by some authors based on their own collections, e.g., An et al. (1983), Chen and Gong (1986), and Dong (1987) (only Cordylodus proavus). Viira et al. (1987) recognized three element types of C. proavus, whereas Barnes (1988) suggested four element types. Nicoll (1990) reinterpreted the apparatus reconstruction of this genus as a septimembrate apparatus containing $\mathrm{M}, \mathrm{S}$, and $\mathrm{P}$ elements. We still use the apparatus reconstruction by Miller (1980). Although this two-element model does not seem to be refined and updated, it is more practical than more complex models. Miller's rounded element includes Nicoll's S elements and probably Nicoll's P elements, and Miller's compressed elements correspond to Nicoll's M elements.

Cordylodus angulatus Pander, 1856

Figures 9.15, 9.17, 9.20, 9.22-9.24, 10.1, 10.2

1856 Cordylodus angulatus Pander, p. 33, pl. 2, figs. 28-31, pl. 3, fig. 10.

1856 Cordylodus rotundatus Pander, p. 33, pl. 2, figs. 32, 33.

1938 Cordylodus subangulatus Furnish, p. 338, text-fig. 2D, pl. 42 , fig. 3 .

1955 Cordylodus angulatus Pander; Lindström, p. 551, pl. 5, fig. 9, text-fig. $3(\mathrm{G})$. 


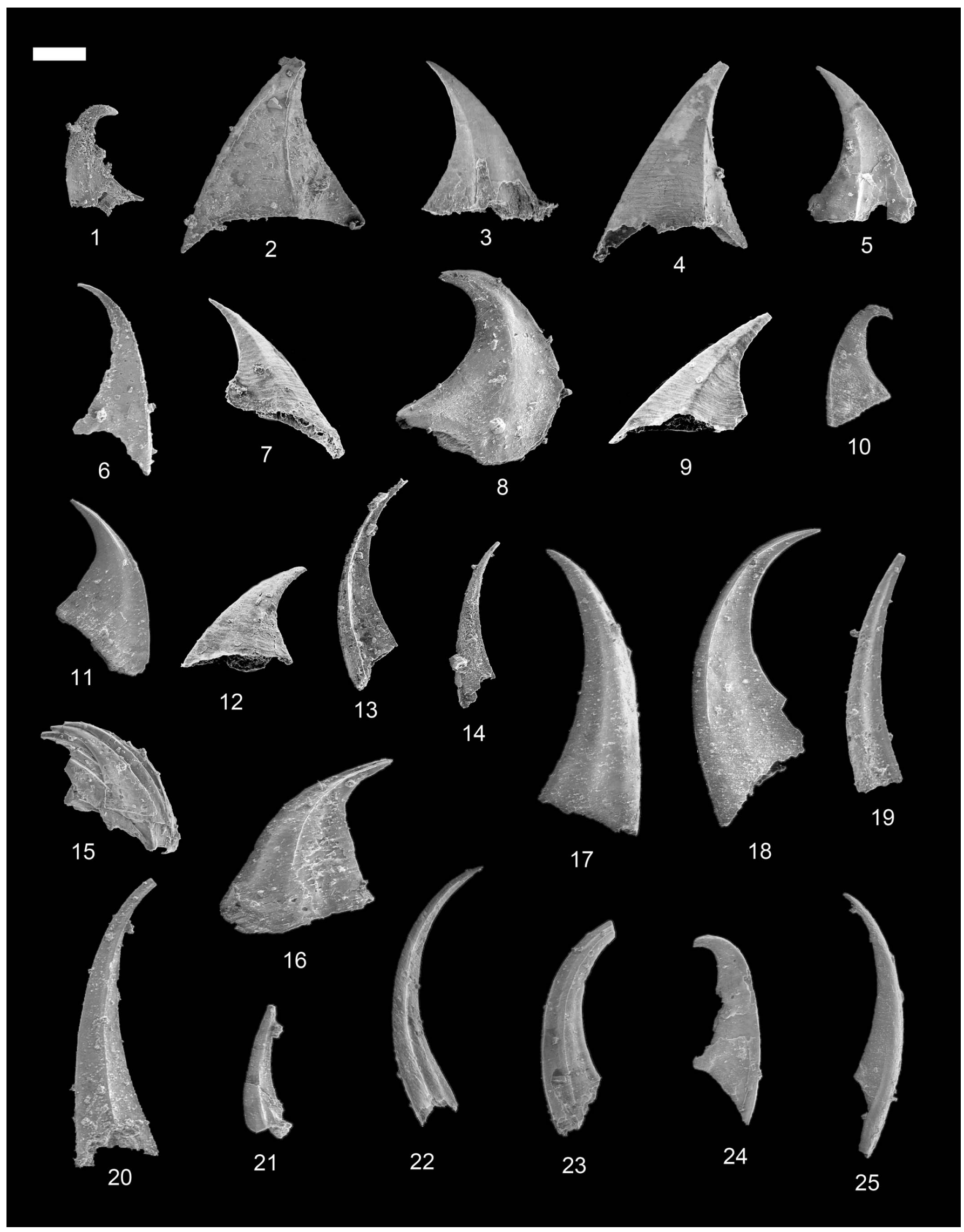



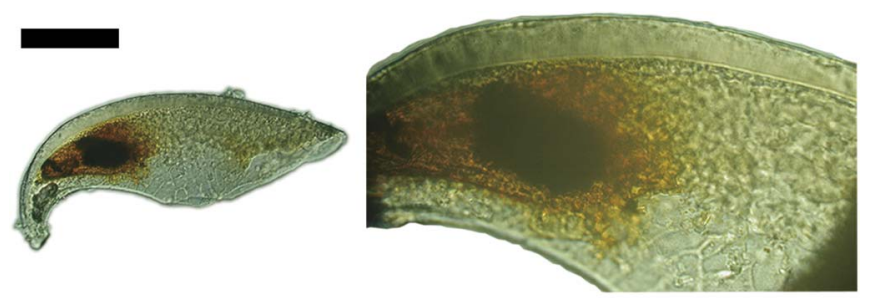

1

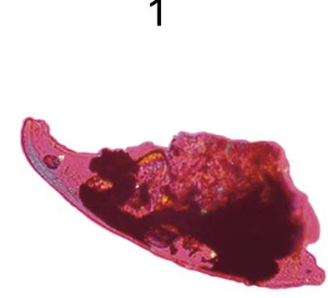

3

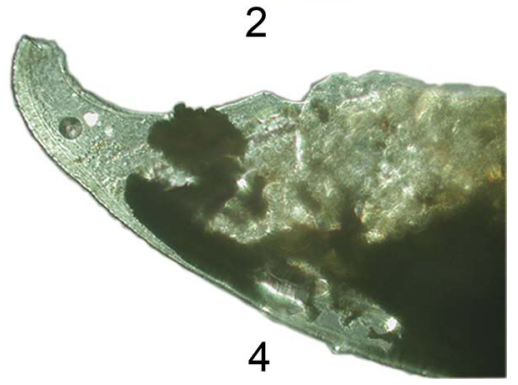

1981 Cordylodus angulatus Pander; An, pl. 2, fig. 17.

1981 Cordylodus rotundatus Pander; An, pl. 1, figs. 18-19.

1982 Cordylodus angulatus Pander; Repetski, p. 16, pl. 4, fig. 9, text-fig. 4 (L).

1982 Cordylodus rotundatus Pander; Repetski, p. 18, pl. 5, fig. 3, text-fig. $4(\mathrm{~N})$.

1983 Cordylodus angulatus Pander; An et al., p. 84, pl. 8, figs. $1,2$.

1983 Cordylodus rotundatus Pander; An et al., p. 88-89, pl. 8, figs. 3-7.

1985 Cordylodus rotundatus Pander; Nowlan, p. 111, text-fig. 4 (3).

1985 Cordylodus angulatus Pander; Wang, p. 215, pl. 1, figs. 1-3, pl. 7, figs. 11-14, pl. 10, figs. 17 (not 15), pl. 11 , figs. 17,18 (?), pl. 12, figs. 18 (?), 19, 20 (?), pl. 14, fig. 7 (not 8) (part).

1985 Cordylodus rotundatus Pander; Wang, p. 219, pl. 1, fig. 5, pl. 7, figs. 25, 26; pl. 11, fig. 22.

Figure 8. Conodont images using oil immersion techniques (Dong et al., 2005c) with Differential Interference Contrast (Nomarski) illumination. (1-4) Coelocerodontus bicostatus van Wamel, 1974; (1) overview, GMPKU2254, showing the crown structure of euconodont; (2) close-up of (1); (3) overview, GMPKU2255, showing the crown structure of euconodont; (4) close-up of (3). Relative scale bar represents $109 \mu \mathrm{m}(\mathbf{1}, \mathbf{3}), 38 \mu \mathrm{m}(\mathbf{2}, \mathbf{4})$.

1955 Cordylodus rotundatus Pander; Lindström, p. 553, pl. 5, figs. 17-20, text-fig. 3 (F).

1971 Cordylodus angulatus Pander; Druce and Jones, p. 66, pl. 3, figs. 4-6, text-figs. 23a, b.

1971 Cordylodus rotundatus Pander; Druce and Jones, p. 71, text-figs. 23t, pl. 3, figs. 8-10.

1971 Cordylodus sp. A Druce and Jones, p. 72, text-fig. 23u, pl. 8, fig. 10a, b.

1971 Cordylodus rotundatus Pander; Ethington and Clark, pl. 1, fig. 17.

1971 Cordylodus angulatus Pander; Ethington and Clark, pl. 1, 15, 16, 20.

1973 Cordylodus angulatus Pander; Müller, p. 27, pl. 11, figs. $1-7$, text-fig. $2 \mathrm{G}$.

1973 Cordylodus rotundatus Pander; Müller, p. 36, text-figs. 2H, 10a, b, pl. 11, figs. 8-10.

1974 Cordylodus rotundatus Pander; van Wamel, pl. 1, 2000 fig. 14.

1980 Cordylodus angulatus Pander; Miller, p. 13, pl. 1, figs. 22, 2000 text-fig. 4Q.

1980 Cordylodus rotundatus Pander; Miller, p. 20-21, pl. 1, 2001 fig. 24, text-fig. 4p.

1985 Cordylodus angulatus Pander; Dong, p. 394, pl. 1, fig. 6, pl. 3, fig. 5, text-fig. 1 (J).

1985 Cordylodus rotundatus Pander; Dong, p. 396, pl. 2, fig. 8, pl. 3, fig. 9, text-fig. 1L.

1986 Cordylodus angulatus Pander; Chen and Gong, p. 125, pl. 34, figs. 2-4, text-fig. 36.

1986 Cordylodus rotundatus Pander; Chen and Gong, p. 133, pl. 37, figs. 3, 8, 18, text-fig. 41.

1987 Cordylodus angulatus Pander; Dong, p. 153, pl. 1, figs. 17, 18, 22, text-figs. 3H, J, 4F.

1987 Cordylodus rotundatus Pander; Dong, p. 155, pl. 1, fig. 20 only (not 23), text-fig. 3I only (not K).

1990 Cordylodus angulatus Pander; Nicoll, figs. 3 (4b-c only), 5 (3a-4c only), 12.

1994 Cordylodus angulatus Pander; Ji and Barnes, p. 31, pl. 5, figs. 1-9.

1994 Cordylodus angulatus Pander; Wright and Cooper, p. 471, fig. 17B.

1996 Cordylodus angulatus Pander; Lee et al., p. 99, pl. 2, fig. 1.

1998 Cordylodus angulatus Pander; Rao and Tortello, p. 43, pl. 1, figs. 1, 2, 3, 6 .

Cordylodus angulatus Pander; Zhao et al., p. 194, pl. 37, figs. 13, 14, 16, 17.

Cordylodus rotundatus Pander; Zhao et al., p. 194, pl. 37, figs. 7-12.

Cordylodus angulatus Pander; Pyle and Barnes, p. 1397, pl. 1, figs. 3,4 .

Figure 7. (1-12, 16-18) Coelocerodontus bicostatus van Wamel, 1974; (1) Shenjiawan Formation, Wangcun section, GMPKU2399, lateral view; (2) Bitiao Formation, Wangcun section, GMPKU2400, lateral view; (3) Bitiao Formation, Wangcun section, GMPKU2401, lateral view; (4) Bitiao Formation, Wangcun section, GMPKU2402, lateral view; (5) Bitiao Formation, Wangcun section, GMPKU2403, lateral view; (6) Shenjiawan Formation, Wa'ergang section, GMPKU2404, lateral view; (7) Bitiao Formation, Wa'ergang section, GMPKU2405, lateral view; (8) Huaqiao Formation, Wangcun section, GMPKU2413, (9) Bitiao Formation, Wa'ergang section, GMPKU2406, lateral view; (10) Shenjiawan Formation, Wa'ergang section, GMPKU2407, lateral view; (11) Panjiazui Formation, Wa'ergang section, GMPKU2408, lateral view; (12) Bitiao Formation, Wa'ergang section, GMPKU2409, lateral view; (16) Panjiazui Formation, Wa'ergang section, GMPKU2410, lateral view; (17) Panjiazui Formation, Wa'ergang section, GMPKU2411, lateral view; (18) Panjiazui Formation, Wa'ergang section, GMPKU2412, lateral view; (13-15, 19-25) Coelocerodontus hunanensis n. sp.; (13) Shenjiawan Formation, Wangcun section, GMPKU2414, lateral view; (14) Shenjiawan Formation, Wangcun section, GMPKU2415, lateral view; (15) Shenjiawan Formation, Wa'ergang section, GMPKU2416, cluster; (19) Shenjiawan Formation, Wa'ergang section, GMPKU2417, lateral view; (20) Shenjiawan Formation, Wa'ergang section, GMPKU2418, lateral view; (21) Shenjiawan Formation, Wa'ergang section, GMPKU2419, lateral view; (22) Shenjiawan Formation, Wa'ergang section, GMPKU2420, lateral view; (23) Shenjiawan Formation, Wa'ergang section, GMPKU2421, lateral view; (24) Shenjiawan Formation, Wa'ergang section, GMPKU2422, lateral view; (25) Shenjiawan Formation, Wa'ergang section, GMPKU2423, lateral view. Relative scale bar represents $147 \mu \mathrm{m}(\mathbf{1 - 1 1}, \mathbf{1 4}, \mathbf{1 6}-\mathbf{2 5}), 135 \mu \mathrm{m}(\mathbf{1 2}, \mathbf{1 3}, \mathbf{1 5})$. 


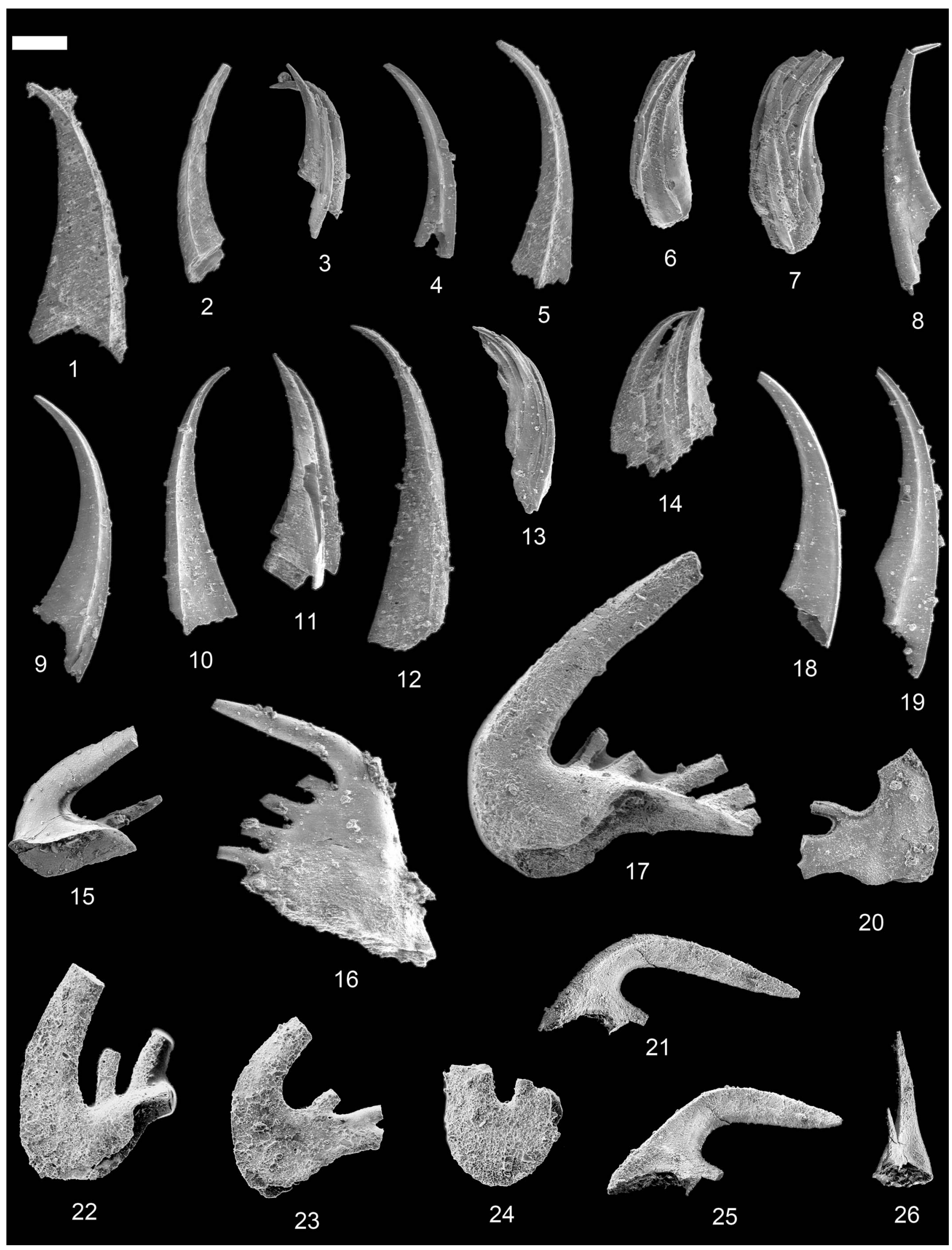


2002 Cordylodus angulatus Pander; Pyle and Barnes, p. 177, pl. 4, figs. 1-3.

2003 Cordylodus angulatus Pander; Heinsalu et al., p. 147, text-fig. 5, 24 (only).

2004c Cordylodus angulatus Pander; Dong et al., p. 1201, pl. 2, figs. 17, 28, 30, pl. 4, figs. 4, 6, 12, 14.

2005 Cordylodus angulatus Pander; Ortega and Albanesi, p. 365 , fig. 5 (14).

2007 Cordylodus angulatus Pander; Pyle et al., p. 1735, fig. 11.8, 11.9 .

Description.-Bimembrate apparatus of rounded and compressed elements. Rounded element with cusp and denticles rounded or oval in cross section and composed mostly of white matter. Basal cavity shallow to moderately deep, usually extending not higher than top of posterior denticulate process. Anterior edge of basal cavity strongly concave and tip recurved. Anterobasal margin slightly rounded to well rounded. Posterior process without carina or with a carina on one side. Compressed element symmetrical or subsymmetrical, with long posterior denticulate process. Cusp and denticles compressed laterally with sharp edges. Basal cavity shallow to moderately deep. Anterior edge of basal cavity slightly concave.

Materials._-12 specimens.

Occurrence.-Known from the Wa'ergang section, where it occurs in the Cordylodus angulatus Zone (lower part).

Remarks.-Miller (1980) suggested that the two form-species Cordylodus angulatus and Cordylodus rotundatus belong to two multielement species mainly based on the minor differences between them. However, many conodont workers considered the two form-species to be a single apparatus, because the two form-species commonly occur together. Based on the common association of the two form-species recovered from Hunan, we follow the opinion of the majority.

Cordylodus caseyi Druce and Jones, 1971

Figures 9.21, 9.25, 9.26, 11.4

1971 Cordylodus caseyi Druce and Jones, p. 67, pl. 2, figs. 9-12, text-figs. 23d, e.

1990 Cordylodus caseyi Druce and Jones; Nicoll, p. 543, figs. 3 (3b), 13 (4a-5c), 14 (1-2) only.
1993 Cordylodus caseyi Druce and Jones; Landing, p. 14, fig. 8, 3-13, p. 15, fig. 9, 1-11.

2001 Cordylodus caseyi Druce and Jones; Pyle and Barnes, p. 1397, pl. 1, fig. 6 .

2002 Cordylodus caseyi Druce and Jones; Pyle and Barnes, p. 177, pl. 4, figs. 4-7.

2003 Cordylodus caseyi Druce and Jones; Landing et al., p. 86, fig. 7, 16 (only).

Description.-The element is asymmetrical. The long cusp is reclined, oval in cross-section. The base is greatly expanded to give a triangular cross section in the basal view. The basal cavity is moderately large with anterior edge concave or straight. A conspicuous keel is developed on the lateral margin of the cusp and base.

Materials._-26 specimens.

Occurrence.-Known from the Wa'ergang section, where it occurs in the Cordylodus lindstromi Zone.

Remarks.-This species is characterized by its expanded base with a triangular cross-section and the keel developed on the lateral margin of the cusp and base. Only rounded elements have been found for this species.

Cordylodus intermedius Furnish, 1938

Figures 10.3-10.6, 11.1-11.3, 11.5-11.27, 12.1-12.4, 12.7

1938 Cordylodus intermedius Furnish, p. 338, pl. 42, fig. 31, text-fig. 2c.

1955 Cordylodus prion Lindström, p. 552, pl. 5, figs. 14-16.

1971 Cordylodus intermedius Furnish; Druce and Jones, p. 68 , pl. 3 , figs. $1-3$, text-figs. $23 \mathrm{f}$, g.

1971 Cordylodus oklahomensis Müller; Druce and Jones, p. 69 , pl. 5, figs. $6-7$, text-fig. 23j.

1971 Cordylodus prion Lindström; Lindström, pl. 2, figs. 1-7, text-figs. 23i, k-o.

1971 Cordylodus proavus Müller; Druce and Jones, p. 70, text-fig. 23p, pl. 1, fig. 1 only (not figs. 2-6). (part)

1973 Cordylodus intermedius Furnish; Müller, p. 30, pl. 10, figs. 1-3, text-figs. 2c, $4 \mathrm{a}$, b.

Figure 9. (1-14, 18, 19) Coelocerodontus hunanensis n. sp.; (1) Shenjiawan Formation, Wa'ergang section, GMPKU2424, lateral view; (2) Shenjiawan Formation, Wa'ergang section, GMPKU2425, lateral view; (3) Shenjiawan Formation, Wa'ergang section, GMPKU2426, cluster, lateral view; (4) Shenjiawan Formation, Wa'ergang section, GMPKU2427, lateral view; (5) Shenjiawan Formation, Wa'ergang section, GMPKU2428, lateral view; (6) Shenjiawan Formation, Wa'ergang section, GMPKU2429, cluster, lateral view; (7) Panjiazui Formation, Wa'ergang section, GMPKU2430, cluster, lateral view; (8) Panjiazui Formation, Wa'ergang section, GMPKU2431, lateral view; (9) Panjiazui Formation, Wa'ergang section, holotype, GMPKU2432, lateral view; (10) Panjiazui Formation, Wa'ergang section, GMPKU2433, lateral view; (11) Panjiazui Formation, Wa'ergang section, GMPKU2434, cluster, lateral view; (12) Panjiazui Formation, Wa'ergang section, GMPKU2435, lateral view; (13) Panjiazui Formation, Wa'ergang section, GMPKU2436, cluster, lateral view; (14) Panjiazui Formation, Wa'ergang section, GMPKU2437, cluster, lateral view; (18) Panjiazui Formation, Wa'ergang section, GMPKU2438, lateral view; (19) Panjiazui Formation, Wa'ergang section, GMPKU2439, lateral view; (15, 17, 20, 22-24) Cordylodus angulatus Pander, 1856; (15) Panjiazui Formation, Wa'ergang section, GMPKU2440, lateral view; (17) Panjiazui Formation, Wa'ergang section, GMPKU2441, lateral view; (20) Panjiazui Formation, Wa'ergang section, GMPKU2442, lateral view; (22) Panjiazui Formation, Wa'ergang section, GMPKU2169, lateral view; (23) Panjiazui Formation, Wa'ergang section, GMPKU2170, lateral view; (24) Panjiazui Formation, Wa'ergang section, GMPKU2171, lateral view; (16) Cordylodus proavus Müller, 1959, Panjiazui Formation, Wa'ergang section, GMPKU2443, lateral view; (21, 25, 26) Cordylodus caseyi Druce and Jones, 1971; (21) Panjiazui Formation, Wa'ergang section, GMPKU2444, lateral view; (25) Panjiazui Formation, Wa'ergang section, GMPKU2446, lateral view; (26) Panjiazui Formation, Wa'ergang section, GMPKU2447, posterior view. Relative scale bar represents $158 \mu \mathrm{m}(\mathbf{1 , 2}, \mathbf{4 - 1 9}, \mathbf{2 2}), 150 \mu \mathrm{m}(\mathbf{3}, \mathbf{2 0}, \mathbf{2 1}, \mathbf{2 3}-\mathbf{2 6})$. 

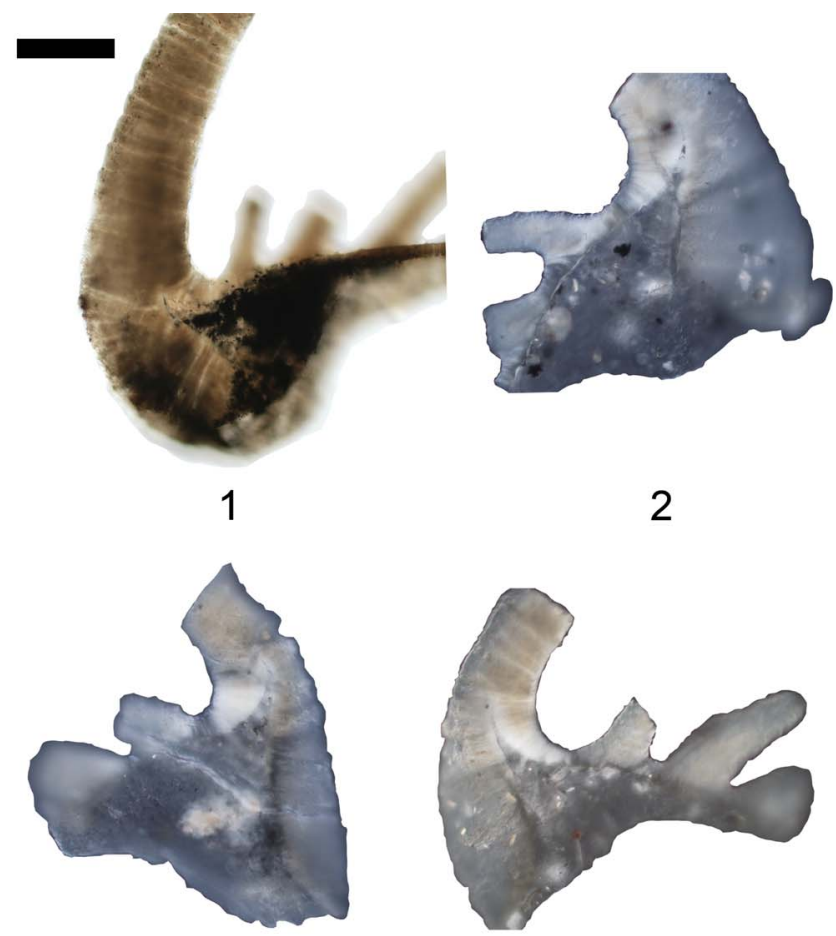

2

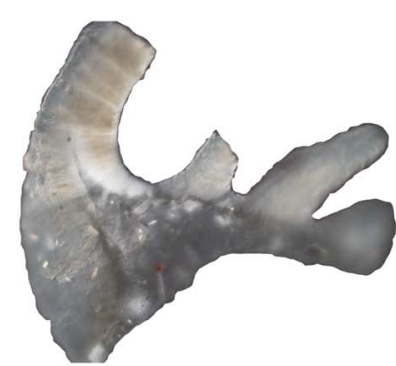

4
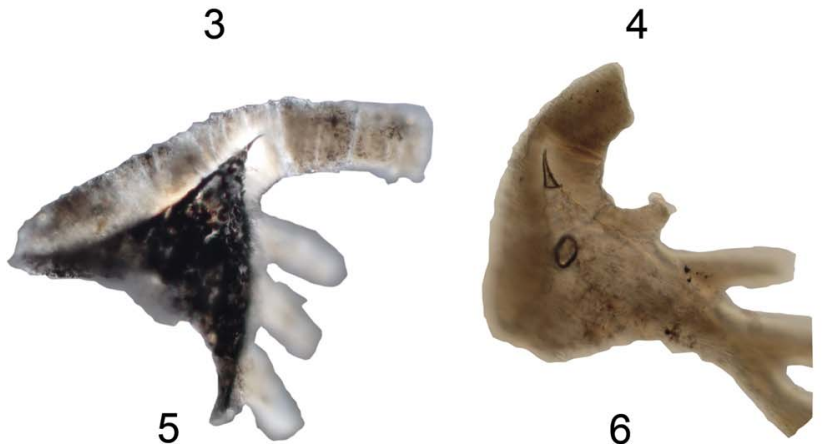

Figure 10. Conodont images using oil immersion techniques (Dong et al., 2005c) with Differential Interference Contrast (Nomarski) illumination, showing the shapes of basal cavities. $(1,2)$ Cordylodus angulatus Pander, 1856; (1) the same specimen as Figure 9.17 ; $(2)$ the same specimen as Figure 9.20; (3-6) Cordylodus intermedius Furnish, 1938; (3) the same specimen as Figure $12.1 ;(4)$ the same specimen as Figure 12.2; (5) the same specimen as Figure 12.3; (6) the same specimen as Figure 12.7. Relative scale bar represents $167 \mu \mathrm{m}(\mathbf{1}), 109 \mu \mathrm{m}(\mathbf{2}, \mathbf{5}), 103 \mu \mathrm{m}(\mathbf{3 , 4}, \mathbf{6})$.

1973 Cordylodus prion Lindström; Müller, p. 33, textfigs. 2E, 8, pl. 10, fig. 4.

1974 Cordylodus prion Lindström; van Wamel, p. 59, pl. 1, figs. 8-9.
1980 Cordylodus intermedius Furnish; Miller, p. 17, pl. 1, fig. 16, text-fig. 4L.

1980 Cordylodus intermedius Furnish; Landing et al., p. 19, figs. 5E, 6A, B.

1982 Cordylodus intermedius Furnish; s.f. Repetski, p. 17, pl. 5, fig. 2, text-fig. 4 (M).

1983 Cordylodus intermedius Furnish; An et al., p. 85, pl. 7, fig. 16.

1985 Cordylodus intermedius Furnish; Wang, p. 215, pl. 1, figs. $12,13,15,14$ (?), pl. 7, figs. 22-24, pl. 9, figs. 5-7, pl. 1 1, figs. 5-7; pl. 13, figs. 22, 23 (not pl. 14, fig. 4). (part)

1985 Cordylodus intermedius Furnish; Dong, p. 394, pl. 2, fig. 6, pl. 3, fig. 10, text-fig. $1 \mathrm{k}$.

1986 Cordylodus intermedius Furnish; Chen and Gong, p. 127 , pl. 35 , figs. $2,3,6,9$, pl. 36, fig. 7, pl. 37, figs. 1, 2, 4-7, 10-11, 13, 15-17, pl. 38, figs. 2, 3, 7-8, 13, 15, text-fig. 38 .

1987 Cordylodus intermedius Furnish; Dong, p. 154, pl. 1, figs. 14, 15, 19, 25, text-figs. 3E, F, L, 4C.

1987 Cordylodus intermedius Furnish; Bagnoli et al., p. 153, pl. 1, figs. 15-18.

1994 Cordylodus intermedius Furnish; Ji and Barnes, p. 32, pl. 5, figs. 10-18.

1998 Cordylodus intermedius Furnish; Rao and Tortello, p. 43 , pl. 1, fig. 7 .

2000 Cordylodus intermedius Furnish; Zhao et al., p. 195, pl. 37, figs. 15, 21.

2000 "Cordylodus" intermedius Furnish; Dubinina, p. 188, pl. 9, fig. 25.

? 2000 "Cordylodus" lenzi Müller; Dubinina, p. 188, pl. 9, fig. 21.

2002 Cordylodus intermedius Furnish; Pyle and Barnes, p. 47 , pl. 4, figs. $15-17$.

2004c Cordylodus intermedius Furnish; Dong et al., pl. 2, figs. 8, 9, 19, 21, 24, pl. 4, figs. 5, 13.

Description.-Bimembrate apparatus of rounded and compressed elements. Rounded element symmetrical or subsymmetrical, possessing a distinctive basal cavity with anterior edge concave or straight. Compressed element may be symmetrical or asymmetrical due to lateral bending of cusp and presence of the slight carina on inner side of basal margin. Cusp and denticles laterally compressed and sharp edges, denticles fused at base.

Materials._-260 specimens.

Figure 11. (1-3, 5-27) Cordylodus intermedius Furnish, 1938; (1) Panjiazui Formation, Wa'ergang section, GMPKU2452, lateral view; (2) Panjiazui Formation, Wa'ergang section, GMPKU2453, lateral view; (3) Panjiazui Formation, Wa'ergang section, GMPKU2454, lateral view; (5) Panjiazui Formation, Wa'ergang section, GMPKU2455, lateral view; (6) Panjiazui Formation, Wa'ergang section, GMPKU2456, lateral view; (7) Panjiazui Formation, Wa'ergang section, GMPKU2457, lateral view; (8) Panjiazui Formation, Wa'ergang section, GMPKU2458, lateral view; (9) Panjiazui Formation, Wa'ergang section, GMPKU2459, lateral view; (10) Panjiazui Formation, Wa'ergang section, GMPKU2460, lateral view; (11) Panjiazui Formation, Wa'ergang section, GMPKU2461, lateral view; (12) Panjiazui Formation, Wa'ergang section, GMPKU2462, lateral view; (13) Panjiazui Formation, Wa'ergang section, GMPKU2463, lateral view; (14) Panjiazui Formation, Wa'ergang section, GMPKU2464, lateral view; (15) Panjiazui Formation, Wa'ergang section, GMPKU2465, lateral view; (16) Panjiazui Formation, Wa'ergang section, GMPKU2466, lateral view; (17) Panjiazui Formation, Wa'ergang section, GMPKU2467, lateral view; (18) Panjiazui Formation, Wa'ergang section, GMPKU2468, lateral view; (19) Panjiazui Formation, Wa'ergang section, GMPKU2469, lateral view; (20) Panjiazui Formation, Wa'ergang section, GMPKU2470, lateral view; (21) Panjiazui Formation, Wa'ergang section, GMPKU2471, lateral view; (22) Panjiazui Formation, Wa'ergang section, GMPKU2472, lateral view; (23) Panjiazui Formation, Wa'ergang section, GMPKU2473, lateral view; (24) Panjiazui Formation, Wa'ergang section, GMPKU2474, lateral view; (25) Panjiazui Formation, Wa'ergang section, GMPKU2475, lateral view; (26) Panjiazui Formation, Wa'ergang section, GMPKU2476, lateral view; (27) Panjiazui Formation, Wa'ergang section, GMPKU2477, lateral view; (4), Cordylodus caseyi Druce and Jones, 1971; Panjiazui Formation, Wa'ergang section, GMPKU2451, lateral view. Relative scale bar represents 180 4 m (1-21, 24-27), $145 \mu \mathrm{m}(\mathbf{2 2}), 154 \mu \mathrm{m}(\mathbf{2 3})$. 


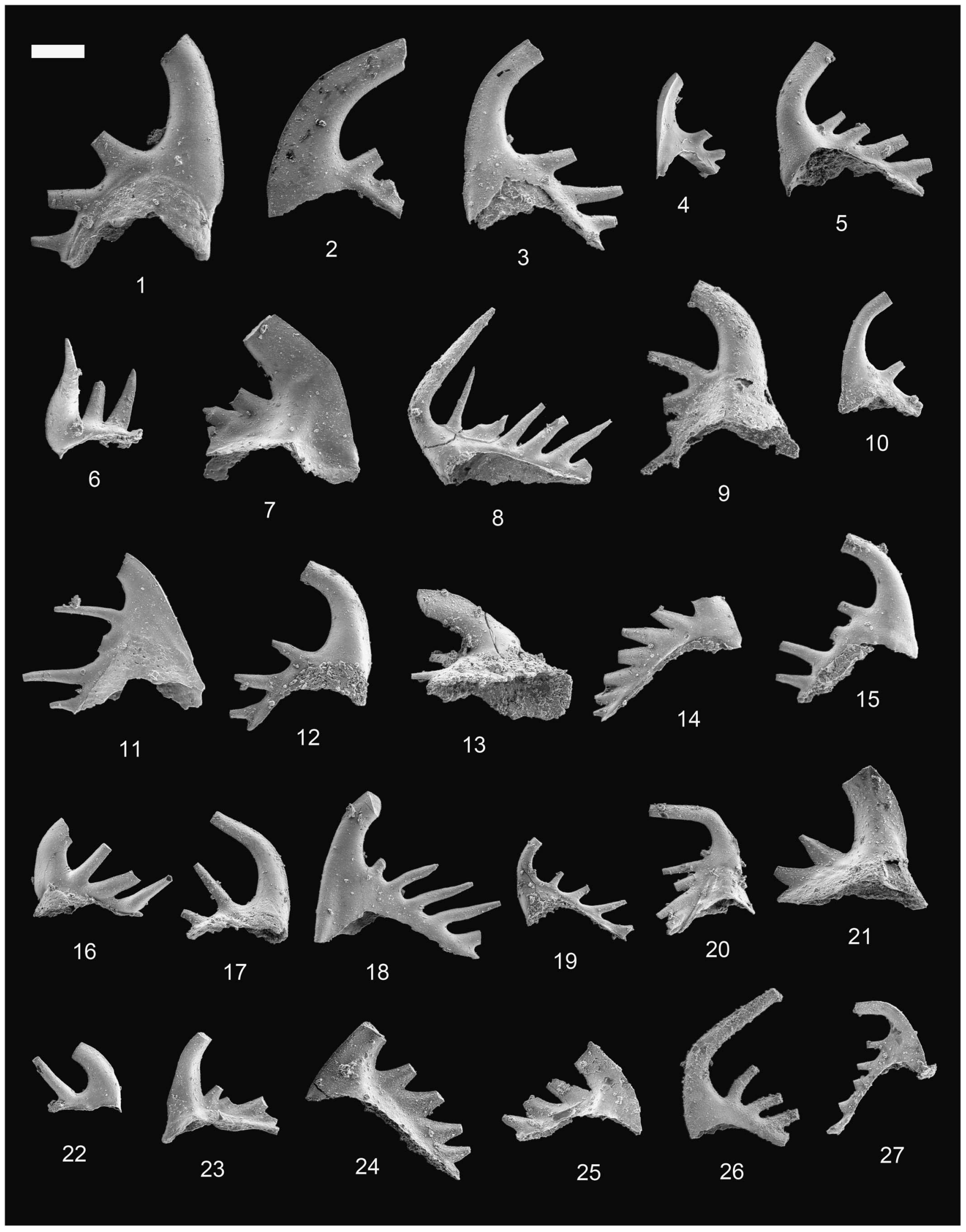


Occurrence.-Known from the Wa'ergang section, where it ranges from the Cordylodus intermedius Zone through the Cordylodus lindstromi Zone (upper part).

Remarks.-The overwhelming majority of conodont workers believed that Cordylodus intermedius is the evolutionary intermediate between Cordylodus proavus and Cordylodus angulatus. Nevertheless, Nicoll (1990) proposed that $C$. intermedius is an invalid species, and that much of the material previously assigned to $C$. intermedius should reassigned to $C$. angulatus and that some of the stratigraphically older specimens probably should be assigned to $C$. proavus. He also replaced the $C$. intermedius Zone by a lower Hirsutodontus simplex Zone and an upper Clavohamamulus hintzei Zone. However, in terms of stratigraphical range, the FAD of $C$. intermedius is just between that of $C$. proavus and that of $C$. angulatus. In terms of morphology, the anterior edge of basal cavity is concave or straight in $C$. intermedius, whereas it is convex in $C$. proavus. Therefore, the reassignment of the stratigraphically older specimens of $C$. intermedius to $C$. proavus is absolutely inconsistent with the orginal definition of the two form-species, even if the reassignment of some specimens of C. intermedius to $C$. angulatus sounds plausible. So far as it goes, Nicoll's (1990) proposal has never been accepted, and $C$. intermedius is unequivocally a valid species, while $C$. intermedius Zone is valid and useful for the work on Cambrian-Ordovician boundary (Cooper et al., 2001; Terfelt et al., 2012)

\section{Cordylodus lindstromi Druce and Jones, 1971 \\ Figures 12.5, 12.6, 12.8-12.26, 13.1-13.15}

1971 Cordylodus lindstromi Druce and Jones, p. 68, pl. 1, figs. 7-9, text-fig. 23h, pl. 2, fig. 8 .

1973 Cordylodus lindstromi Druce and Jones; Müller, p. 22, text-figs. 2d, 6a, b, pl. 9, figs. 10, 11.

1982 Cordylodus lindstromi Druce and Jones; s.f. Repetski, p. 17, pl. 5, figs. 4-5, text-fig. 4 (O).

1983 Cordylodus lindstromi Druce and Jones; An et al., p. 86, pl. 7, figs. 17-19.

1985 Cordylodus lindstromi Druce and Jones; Wang, p. 216, pl. 1, fig. 6, pl. 13, fig. 24.

1986 Cordylodus lindstromi Druce and Jones; Chen and Gong, p. 129, pl. 34, figs. 1, 5-8, text-fig. 39.

1987 Cordylodus lindstromi Druce and Jones; Dong, p. 154, pl. 1, fig. 30, text-fig. 3, G.

1990 Cordylodus lindstromi Druce and Jones; Nicoll, p. 545, fig. 3, (2b only), fig. 16, (7-14 only), fig. 17 (not fig. 18).
1991 Cordylodus lindstromi Druce and Jones; Nicoll, p. 231, figs. 2.3, 2.4, fig. 4. (part)

1994 Cordylodus lindstromi Druce and Jones; Ji and Barnes, p. 32, pl. 5, figs. 19-22.

? 1999 Cordylodus lindstromi Druce and Jones; Parsons and Clark, p. 7, figs. 26-27.

2000 Cordylodus lindstromi Druce and Jones; Göncüoğlu and Kozur, p. 599, fig. 4, g, p. 601, fig. 5, a, g.

2000 "Cordylodus" lindstromi Druce and Jones; Dubinina, p. 188, pl. 9, figs. 15, ?16-17.

2001 Cordylodus lindstromi Druce and Jones; Pyle and Barnes, p. 1397, pl. 1, fig. 7.

2002 Cordylodus lindstromi Druce and Jones; Pyle and Barnes, p. 48, pl. 4, figs. 18-21.

2003 Cordylodus lindstromi Druce and Jones; Heinsalu et al., p. 147, text-fig. 5, 13-14 (only, not 15-20). (part)

2004c Cordylodus lindstromi Druce and Jones; Dong et al., pl. 2, figs. 14, 16, 22, 23, pl. 4, figs. 7, 15.

2007 Cordylodus lindstromi Druce and Jones; Pyle et al., p. 1733 , fig. 10, 3-4.

Description.-Bimembrate apparatus of rounded and compressed elements. Rounded elements and compressed elements symmetrical, with distinctive basal cavities. Secondary apex of basal cavity extends into the first, and rarely the second, denticle. The anterior edge of basal cavity is convex.

Materials._-200 specimens.

Occurrence.-Known from the Wa'ergang section, where it where it occurs in the Cordylodus lindstromi Zone.

Remarks. - The specimens at hand agree well with Cordylodus lindstromi.

\section{Cordylodus proavus Müller, 1959}

Figures 9.16, 14.1-14.23

1959 Cordylodus proavus Müller, p. 448, pl. 15, figs. 11, 12, 18, text-fig. 3B.

1959 Cordylodus oklahomensis Müller, p. 447, text-fig. 3A, pl. 15, figs. 15, 16 .

1969 Cordylodus proavus Müller; Miller, p. 424, pl. 65, figs. 37-45, text-fig. 3D.

Figure 12. (1-4, 7) Cordylodus intermedius Furnish, 1938; (1) Panjiazui Formation, Wa'ergang section, GMPKU2478, lateral view; (2) Panjiazui Formation, Wa'ergang section, GMPKU2479, lateral view; (3) Panjiazui Formation, Wa'ergang section, GMPKU2480, lateral view; (4) Panjiazui Formation, Wa'ergang section, GMPKU2481, lateral view; (7) Panjiazui Formation, Wa'ergang section, GMPKU2482, lateral view; (5, 6, 8-26) Cordylodus lindstromi Druce and Jones, 1971; (5) Panjiazui Formation, Wa'ergang section, GMPKU2483, lateral view; (6) Panjiazui Formation, Wa'ergang section, GMPKU2484, lateral view; (8) Panjiazui Formation, Wa'ergang section, GMPKU2485, lateral view; (9) Panjiazui Formation, Wa'ergang section, GMPKU2486, lateral view; (10) Panjiazui Formation, Wa'ergang section, GMPKU2487, lateral view; (11) Panjiazui Formation, Wa'ergang section, GMPKU2488, lateral view; (12) Panjiazui Formation, Wa'ergang section, GMPKU2489, lateral view; (13) Panjiazui Formation, Wa'ergang section, GMPKU2490, lateral view; (14) Panjiazui Formation, Wa'ergang section, GMPKU2491, lateral view; (15) Panjiazui Formation, Wa'ergang section, GMPKU2492, lateral view; (16) Panjiazui Formation, Wa'ergang section, GMPKU2493, lateral view; (17) Panjiazui Formation, Wa'ergang section, GMPKU2494, lateral view; (18) Panjiazui Formation, Wa'ergang section, GMPKU2496, lateral view; (19) Panjiazui Formation, Wa'ergang section, GMPKU2497, lateral view; (20) Panjiazui Formation, Wa'ergang section, GMPKU2498, lateral view; (21) Panjiazui Formation, Wa'ergang section, GMPKU2499, lateral view; (22) Panjiazui Formation, Wa'ergang section, GMPKU2500, lateral view; (23) Panjiazui Formation, Wa'ergang section, GMPKU2501, lateral view; (24) Panjiazui Formation, Wa'ergang section, GMPKU2502, lateral view; (25) Panjiazui Formation, Wa'ergang section, GMPKU2503, lateral view; (26) Panjiazui Formation, Wa'ergang section, GMPKU2504, lateral view. Relative scale bar represents 128 $\mu \mathrm{m}(\mathbf{1 - 7}, \mathbf{1 1 - 2 0 ,} 22$, 24-26), $114 \mu \mathrm{m}(\mathbf{8}-10,21,23)$. 


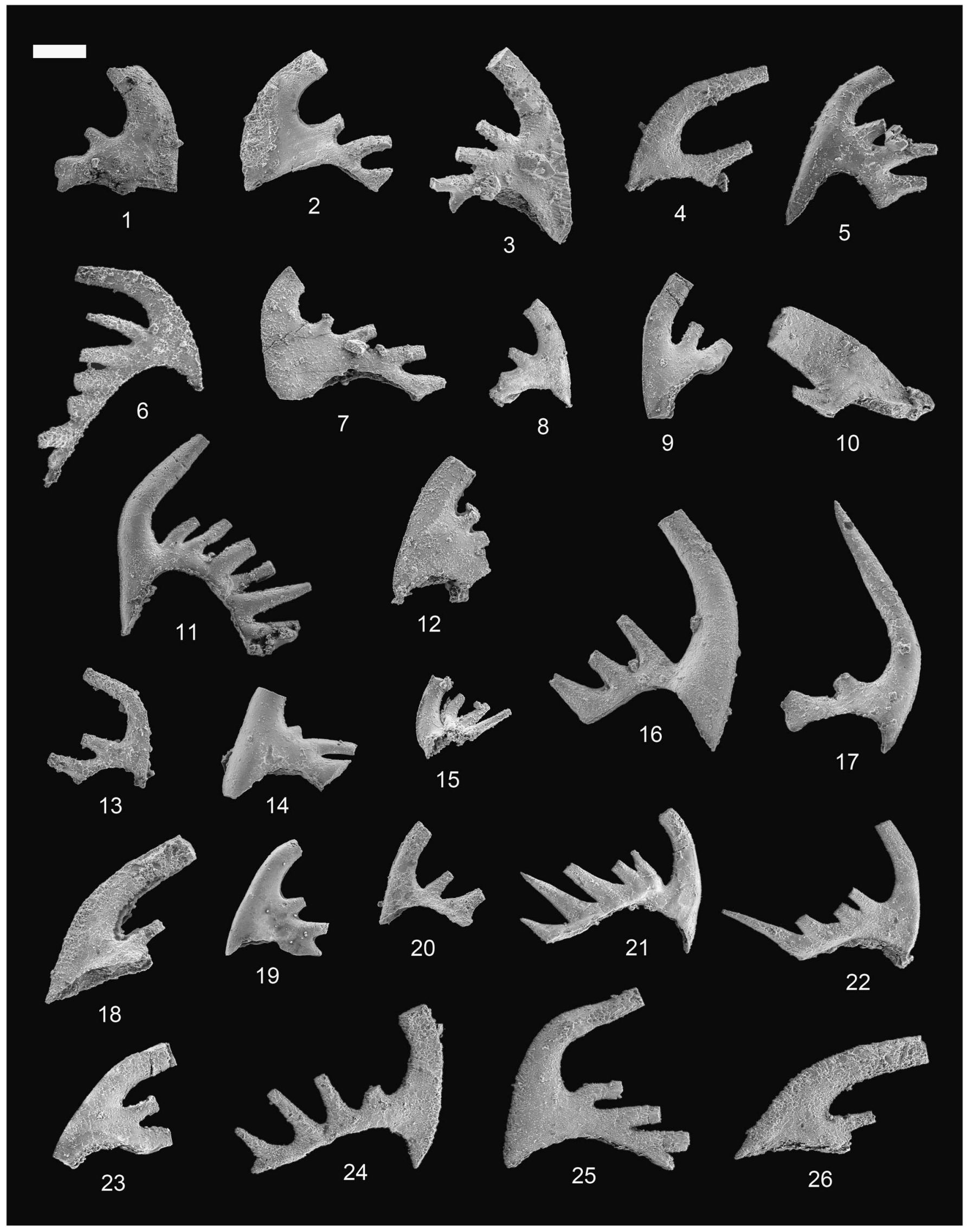




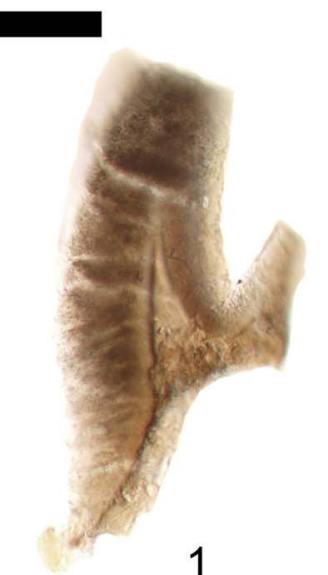

1

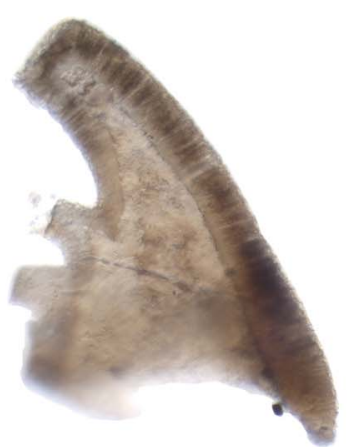

5

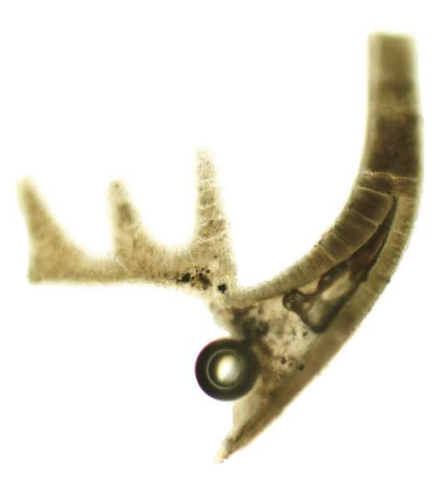

9

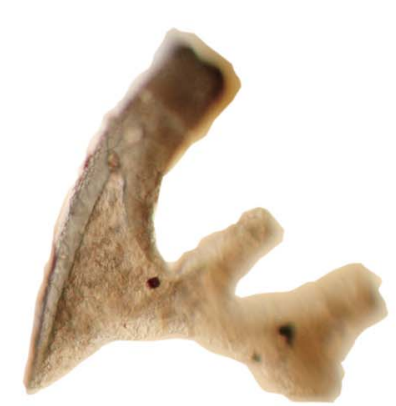

13
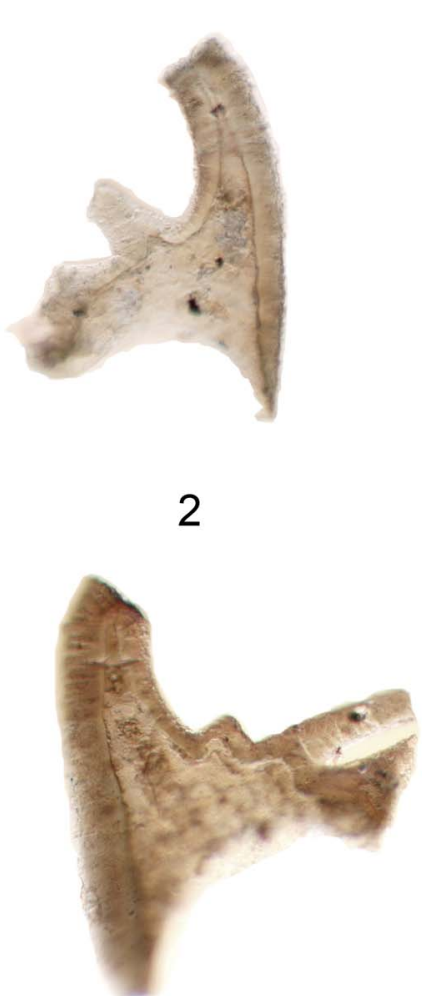

6

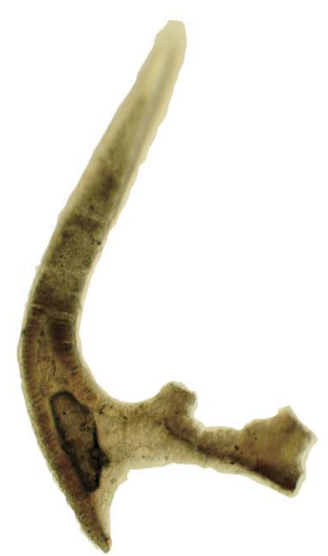

10

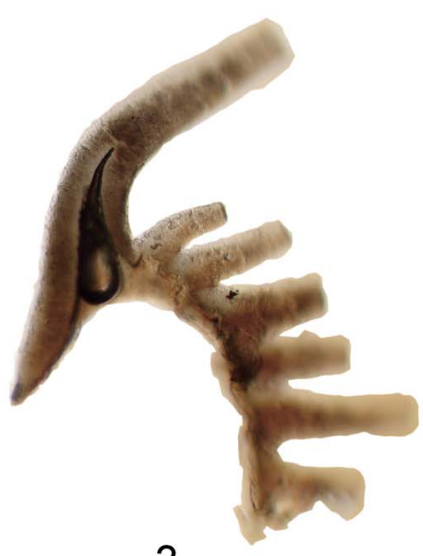

3

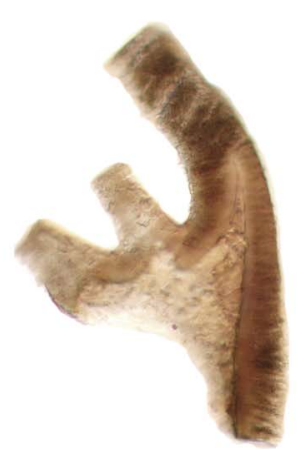

7

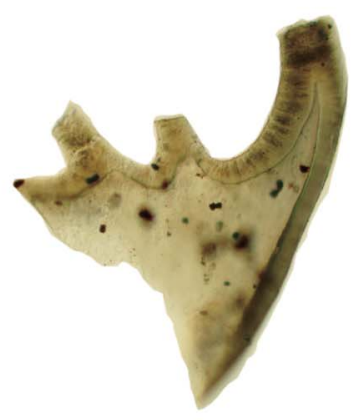

11

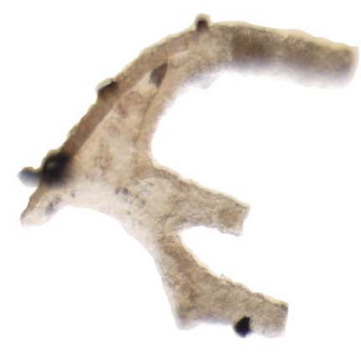

4

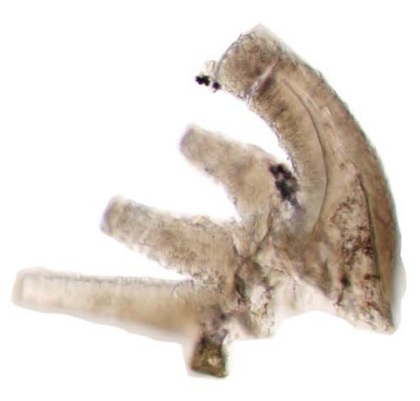

8
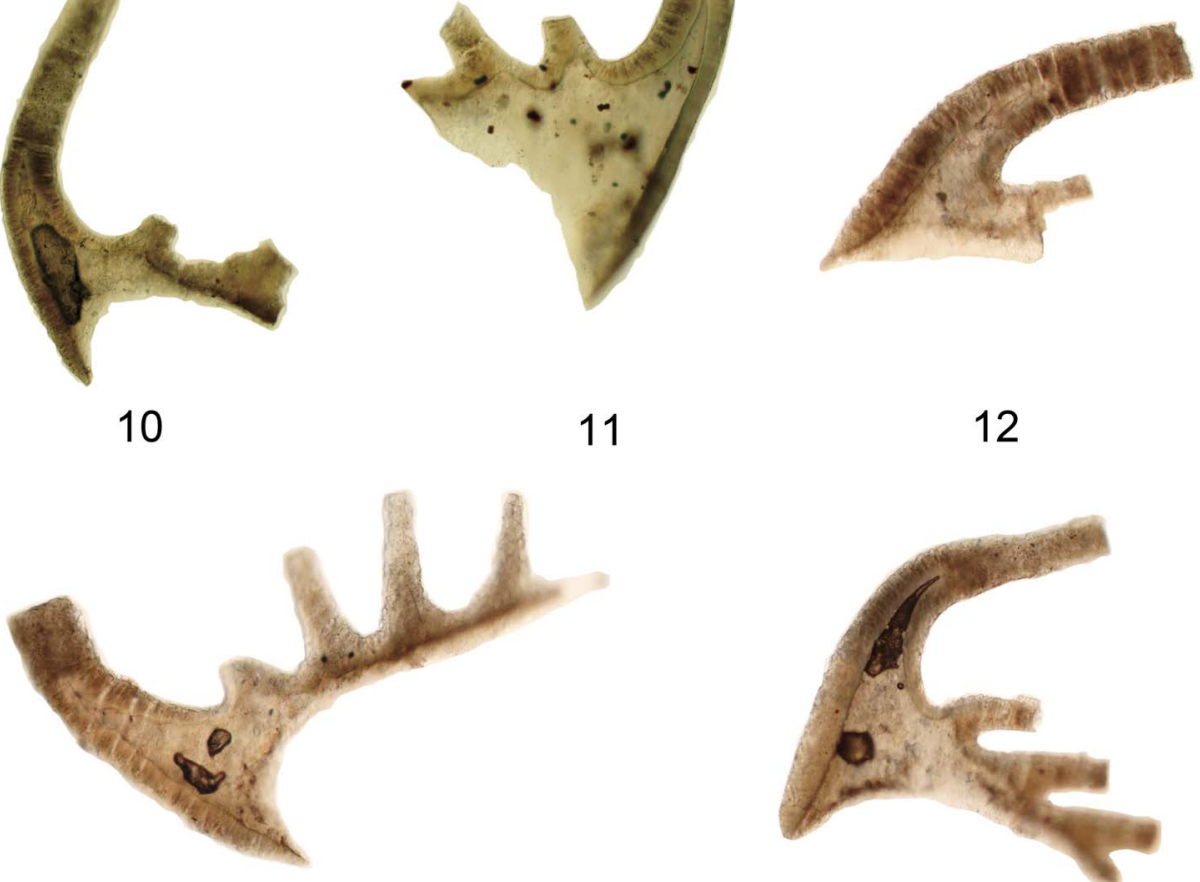

14

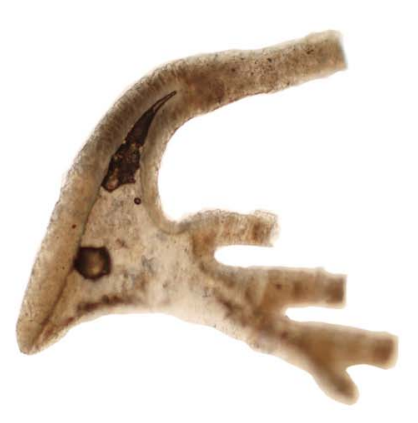

15 
1969 Cordylodus oklahomensis Müller; Miller, p. 423, 2002 text-fig. 3, I, pl. 65, figs. 46-53.

1971 Cordylodus proavus Müller; Druce and Jones, p. 70, pl. 1, figs. 2-6 (not 1), text-fig. 23q, r (not p). (part)

1971 Cordylodus cf. C. proavus Müller; Druce and Jones, p. 71 , pl. 1 , figs. 10,11 (?), 12, text-fig. $23 \mathrm{~s}$.

1971 Cordylodus proavus Müller; Ethington and Clark, pl. 1, fig. 19.

1971 Cordylodus oklahomensis Müller; Ethington and Clark, pl. 1, fig. 24.

1973 Cordylodus proavus Müller; Müller, p. 35, textfigs. 2A, 9, pl. 9, figs. 1-9.

1973 Cordylodus oklahomensis Müller; Müller, p. 33, textfigs. 2b, 7a, b, pl. 9, figs. 12, 13 .

1974 Cordylodus angulatus Pander; van Wamel, pl. 1, fig. 5 (not figs. 6, 7). (part)

1980 Cordylodus proavus Müller; Miller, p. 19-20, textfigs. $4 \mathrm{G}, \mathrm{H}$, pl. 1 , figs. 14,15 .

1983 Cordylodus proavus Müller; An et al., p. 87-88, pl. 7, figs. $1-5,8,11$.

1983 Cordylodus aff. C. proavus Müller; An et al., p. 88, pl. 7, figs. 6, 7, 9, 10, text-fig. 10 (3).

1985 Cordylodus proavus Müller; Dong, p. 395-396, pl. 1, figs. 1, 2, text-figs. 1 (A, B).

1985 Cordylodus proavus Müller; Wang, p. 217, pl. 1, figs. $10,18-23$, pl. 7, figs. 15-20, pl. 9, figs. 9-12, pl. 11, figs. $2-4,19-21$, figs. $2-4,19-21$, pl. 13, figs. 26, 31, pl. 14, figs. 11-16.

1986 Cordylodus proavus Müller; Chen and Gong, p. 130, pl. 35, figs. 1, 4-5, 7-8, 10-14, pl. 36, figs. 1-6, 8-24, pl. 37 , figs. $9,12,14$, pl. 38 , figs. $1,4,6,9,11-12,14$, 16-18, text-fig. 40.

1987 Cordylodus proavus Müller; Dong, p. 155, pl. 1, figs. 7-10, text-fig. 3D.

1990 Cordylodus proavus Müller; Nicoll, p. 550, figs. 3 (1b-d only, not 1a), 19 (2-4 only, not 1), 20-22. (part)

1993 Cordylodus proavus Müller; Landing, p. 14, figs. 8, 16, figs. 9, 14.

1996 Cordylodus proavus Müller; Lee et al., p. 97, pl. 1, figs. 4-5, 9-10.

? 1999 Cordylodus proavus Müller; Parsons and Clark, p. 7, fig. 5 (24-25).

2000 Cordylodus proavus Müller; Dubinina, p. 190, pl. 9, figs. 1-4, 6, 8-10, 14, 19, 20.

2000 Cordylodus proavus Müller; Zhao et al., p. 195, pl. 37, figs. 18-20.

2001 Cordylodus proavus Müller; Lee, p. 451, fig. 7 (20-23).

2002a Cordylodus proavus Müller; Lee, p. 165, pl. 2, figs. 31, 32 .

2002b Cordylodus proavus Müller; Lee, p. 27, pl. 2, figs. 5, 6.
Cordylodus proavus Müller; Pyle and Barnes, p. 49, pl. 5, figs. 4-6.

2003 Cordylodus proavus Müller; Landing et al., p. 86, figs. 7, 11-13.

2003 Cordylodus proavus Müller; Heinsalu et al., p. 147, text-fig. 5 (1-4).

2004 Cordylodus proavus Müller; Lee, p. 60, fig. 5, BB-CC.

2004c Cordylodus proavus Müller; Dong et al., pl. 2, figs. 11, 12, 15, 20, 29, pl. 4, figs. 3, 11.

2006 Cordylodus proavus Müller; Miller et al., p. 394, fig. 9 A, B.

2007 Cordylodus proavus Müller; Landing et al., p. 917, fig. 5 (h-l).

2007 Cordylodus proavus Müller; Pyle et al., p. 1733, fig. 10 (1-2).

Description.-Bimembrate apparatus of rounded and compressed elements, possessing deep basal cavities, the anterior edge of basal cavities is convex, with the tips of basal cavities extending higher than the base of most posterior denticles up to near the apex of the element. Rounded element symmetrical or subsymmetrical. Cusp and denticles round or oval in cross section, composed of white matter. Denticles separated from one another at base. Compressed element asymmetrical due to lateral bending of cusp and due to a carina near the base of inner side. Cusp and denticles composed of white matter, compressed laterally, with keeled anterior and posterior edges. Denticles fused at bases.

Materials.—600 specimens.

Occurrence.-Known from the Wa'ergang section, where it ranges from the Cordylodus proavus Zone through the Cordylodus lindstromi Zone (upper part).

Cordylodus prolindstromi Nicoll, 1991

Figures 14.24-14.30, 15.1-15.35, 16.1-16.26

1991 Cordylodus prolindstromi Nicoll, p. 233, figs. 2 (4), 13 (3-4 only, not 1-2), 14-16.

Materials.-250 specimens.

Occurrence.-Known from Wa'ergang section where it ranges from the Cordylodus intermedius Zone through the Cordylodus lindstromi Zone.

Remarks.-Nicoll (1991) erected Cordylodus prolindstromi and suggested it is the ancestor of Cordylodus lindstromi. The main difference between them is the shape of the second apex of basal cavity. According to Nicoll (1991), in C. lindstromi the

Figure 13. Conodont images using oil immersion techniques (Dong et al., 2005c) with Differential Interference Contrast (Nomarski) illumination, showing the shapes of the biapical basal cavities. (1-15) Cordylodus lindstromi Druce and Jones, 1971; (1) the same specimen as Figure 12.10; (2) the same specimen as Figure 12.8; (3) the same specimen as Figure 12.11; (4), the same specimen as Figure 12.13; (5) the same specimen as Figure 12.12; (6) the same specimen as Figure 12.14; (7) the same specimen as Figure 12.23; (8) the same specimen as Figure 12.15; (9) the same specimen as Figure 12.16; (10) the same specimen as Figure 12.17; (11) the same specimen as Figure 12.19; $(\mathbf{1 2})$ the same specimen as Figure 12.18: (13) the same specimen as Figure 12.20; $(\mathbf{1 4})$ the same specimen as Figure 12.24; $(\mathbf{1 5})$ the same specimen as Figure 12.25 . Relative scale bar represents $80 \mu \mathrm{m}(\mathbf{1}, \mathbf{5}-7, \mathbf{1 1}, \mathbf{1 3}), 67 \mu \mathrm{m}(\mathbf{2}), 121 \mu \mathrm{m}(\mathbf{3}, \mathbf{9}, \mathbf{1 0}, \mathbf{1 2}, \mathbf{1 5}), 92 \mu \mathrm{m}$ (4), $58 \mu \mathrm{m}(\mathbf{8}), 103 \mu \mathrm{m}(\mathbf{1 4})$. 


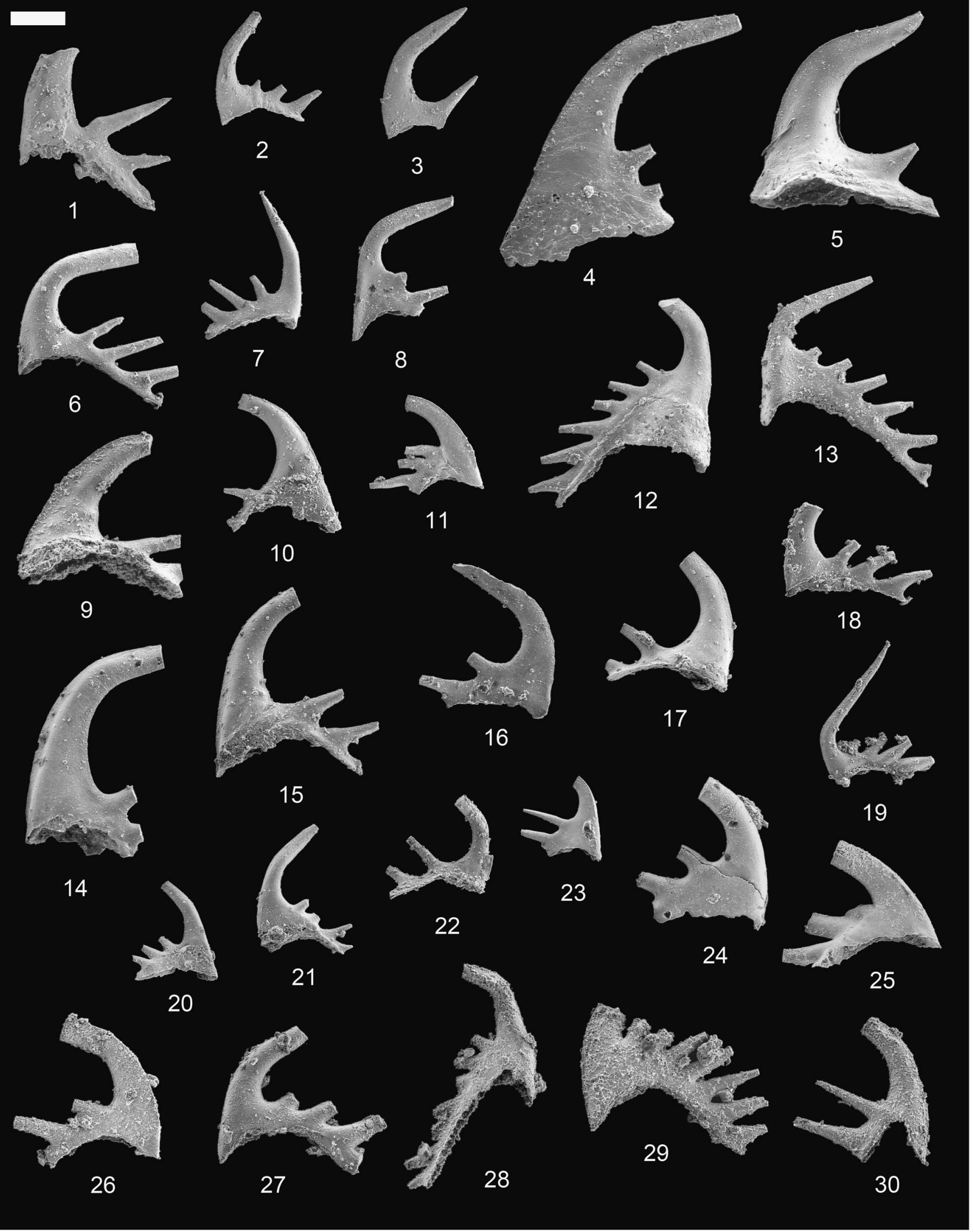


secondary apex of the basal cavity is pointed, whereas in C. prolindstromi, it is truncated by a flat top. In many specimens of $C$. prolindstromi, the tip of the secondary apex of the basal cavity appears to be truncated by a flat top when observed under the ordinary binocular microscope. However, specimens from Hunan have been examined using the oil immersion technique (Dong et al., 2005c). Photomicrographs of these specimens taken with a differential interference contrast (Nomarski) microscope indicate that the shape of the secondary apex is irregular, i.e, it is neither pointed nor truncated by a flat top (Fig. 15). So, the truncated, flat-top shape of the secondary apex may be a preservational artifact. In light of this, $C$. prolindstromi may be a junior synonym of $C$. lindstromi. Nevertheless, because the type specimens of $C$. prolindstromi from Australia have not been examined using the oil immersion technique, we provisionally retain the name of this species.

$$
\text { Genus Dasytodus Chen and Gong, } 1986
$$

Type species.-Proconodontus transmutatus $\mathrm{Xu}$ and Xiang in An et al., 1983.

Dasytodus transmutatus (Xu and Xiang in An et al., 1983) Figure 17.1, 17.2

1983 Proconodontus transmutatus Xu and Xiang in An et al., p. 128, pl. 3, figs. 14-16, pl. 33, fig. 3, text-fig. 9 (22).

1986 Dasytodus transmutatus (Xu and Xiang); Chen and Gong, p. 135, pl. 28, figs. 1, 3-8, 11, text-fig. 43.

2000 Hirsutodontus transmutatus (Xu and Xiang); Duninina, p. 187, pl. 6, figs. 3, 3a, not 6. (part)

2001 Teridontus transmutatus (Xu and Xiang); Lee, p. 449, fig. 6.27, 6.28.

2002a Dasytodus transmutatus (Xu and Xiang); Lee, p. 165, pl. 2, fig. 17.

2002b Teridontus transmutatus (Xu and Xiang); Lee, p. 27, pl. 2, fig. 2.3.

2008a Dasytodus transmutatus (Xu and Xiang); Lee, p. 228, fig. 1 (6).

Description.-Coniform elements, proclined and asymmetrical. Cusp short with rounded cross section. Base long and flaring downwards. Small spines scattered mainly on the base but also on the cusp. Basal cavity deep, with the apex extending up to slightly below the point of flexure of the cusp.
Comparison.-Dasytodus transmutatus differs from Granatodontus ani mainly in the spiny surface ornamentation in the former rather than tiny nodular surface ornamentation in the latter.

Materials.-Six specimens.

Occurrence.-Known from the Wangcun and Wa'ergang sections, where it ranges from the Proconodontus Zone through the Cordylodus proavus Zone.

Remarks.-The specimens at hand agree closely with those illustrated and described by Chen and Gong (1986), except that spines are scattered also on the cusp in the Hunan material. This difference is considered here to represent intraspecific variation.

Genus Eoconodontus Miller, 1980

Type species._Proconodontus notchpeakensis Miller, 1969.

\section{Eoconodontus notchpeakensis (Miller, 1969)}

Figure 17.3-17.17

1967 Oneotodus nakamurai Nogami, p. 216, text-fig. 3D, E (not text-fig. 3A-C), pl. 1, figs. 10, 11 (not figs. 9, 12, 13). (part)

1969 Proconodontus notchpeakensis Miller, p. 438, textfig. 5G, pl. 66, figs. 21-29.

1969 Proconodontus carinatus Miller, p. 437, text-fig. 5I, pl. 66, figs. 15-20 (not figs. 13, 14). (part)

1971 Oneotodus nakamurai Nogami; Druce and Jones, p. 82, text-fig. 26j, pl. 10, figs. 1, 2, 5, 6 (not figs. 3, 4, 7, 8). (part)

1973 Proconodontus notchpeakensis Miller; Müller, p. 43, pl. 4, fig. 6.

1975 Oneotodus nakamurai Nogami; Lee, p. 81, text-figs. 2E, G, pl. 1, figs. 6, 9, 10.

1977 Oneotodus nakamurai Nogami; Abaimova and Markov, p. 92, pl. 14, figs. 12-14, 16.

1980 Eoconodontus notchpeakensis (Miller); Miller, p. 22, pl. 1, figs. 10-12, text-figs. 3D, E.

1982 Proconodontus notchpeakensis Miller; An, p. 142, pl. 8, fig. 2, pl. 13, figs. 1-11.

1983 Proconodontus notchpeakensis Miller; An et al., p. 127, pl. 5, figs. 10-12 (not figs. 19, 20). (part)

Figure 14. (1-23) Cordylodus proavus Müller, 1959; (1) Shenjiawan Formation, Wa'ergang section, GMPKU2505, lateral view; (2) Shenjiawan Formation, Wa'ergang section, GMPKU2506, lateral view; (3) Shenjiawan Formation, Wa'ergang section, GMPKU2507, lateral view; (4) Panjiazui Formation, Wa'ergang section, GMPKU2508, lateral view; (5) Panjiazui Formation, Wa'ergang section, GMPKU2509, lateral view; (6) Panjiazui Formation, Wa'ergang section, GMPKU2510, lateral view; (7) Panjiazui Formation, Wa'ergang section, GMPKU2511, lateral view; (8) Panjiazui Formation, Wa'ergang section, GMPKU2512, lateral view; (9) Panjiazui Formation, Wa'ergang section, GMPKU2513, lateral view; (10) Panjiazui Formation, Wa'ergang section, GMPKU2514, lateral view; (11) Panjiazui Formation, Wa'ergang section, GMPKU2515, lateral view; (12) Panjiazui Formation, Wa'ergang section, GMPKU2516, lateral view; (13) Panjiazui Formation, Wa'ergang section, GMPKU2517, lateral view; (14) Panjiazui Formation, Wa'ergang section, GMPKU2518, lateral view; (15) Panjiazui Formation, Wa'ergang section, GMPKU2519, lateral view; (16) Panjiazui Formation, Wa'ergang section, GMPKU2520, lateral view; (17) Panjiazui Formation, Wa'ergang section, GMPKU2521, lateral view; (18) Panjiazui Formation, Wa'ergang section, GMPKU2522, lateral view; (19) Panjiazui Formation, Wa'ergang section, GMPKU2523, lateral view; (20) Panjiazui Formation, Wa'ergang section, GMPKU2524, lateral view; (21) Panjiazui Formation, Wa'ergang section, GMPKU2525, lateral view; (22) Panjiazui Formation, Wa'ergang section, GMPKU2526, lateral view; (23) Panjiazui Formation, Wa'ergang section, GMPKU2527, lateral view; (24-30) Cordylodus prolindstromi Nicoll, 1991; (24) Panjiazui Formation, Wa'ergang section, GMPKU2528, lateral view; (25) Panjiazui Formation, Wa'ergang section, GMPKU2529, lateral view; (26) Panjiazui Formation, Wa'ergang section, GMPKU2530, lateral view; (27) Panjiazui Formation, Wa'ergang section, GMPKU2531, lateral view; (28) Panjiazui Formation, Wa'ergang section, GMPKU2532, lateral view; (29) Panjiazui Formation, Wa'ergang section, GMPKU2533, lateral view; (30) Panjiazui Formation, Wa'ergang section, GMPKU2534, lateral view. Relative scale bar represents $145 \mu$ m (1, 3-10, 12-16, 19, 21, 22, 24, 27, 29), $136 \mu \mathrm{m}(2,11,17,18,20,23,25,26,28,30)$. 


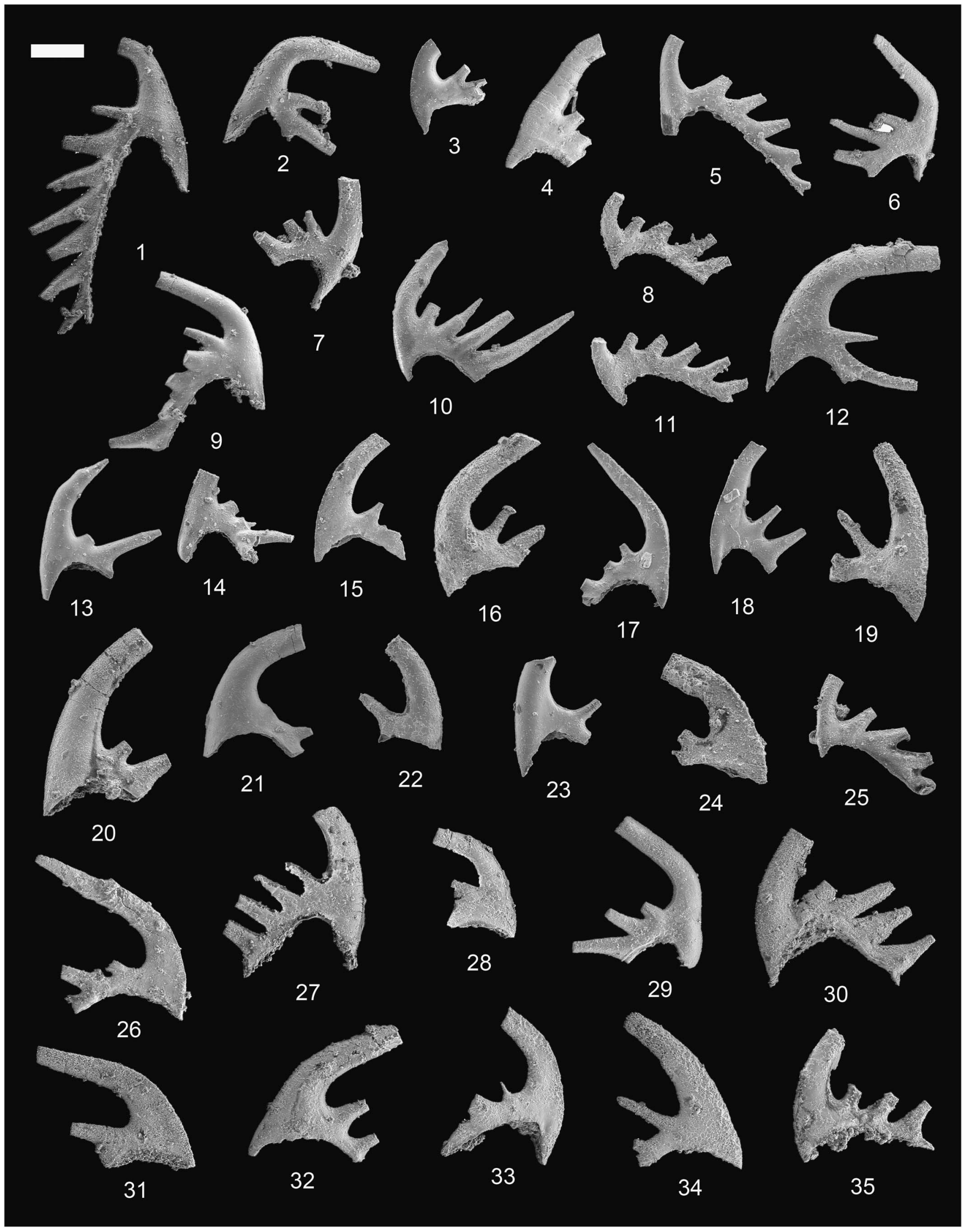


1985 Eoconodontus notchpeakensis (Miller); Wang, p. 223, pl. 3, figs. $8-10$, pl. 4, figs. 10, 11, pl. 7, figs. 1-3, pl. 13, figs. 4, 13, 14, pl. 14, fig. 18 .

1985 Eoconodontus notchpeakensis (Miller); Dong, p. 399, pl. 1, figs. 3, 4, text-figs. 1C-D.

1986 Eoconodontus notchpeakensis (Miller); Chen and Gong, p. 140, pl. 19, fig. 13, pl. 31, figs. 2, 6, 8, pl. 32, figs. 2, 4, 6-7, 9, 11, pl. 33, figs. 2, 8, text-fig. 48 .

1987 Eoconodontus notchpeakensis (Miller); Dong, p. 163, pl. 1, figs. 1, 2, pl. 3, figs. 20, 21.

1993 Eoconodontus notchpeakensis (Miller); Landing, p. 6, fig. $4(4,6,9)$.

1996 Eoconodontus notchpeakensis (Miller); Lee et al., p. 97, pl. 1, figs. 6-7.

2000 Eoconodontus notchpeakensis (Miller); Dubinina, p. 192, pl. 7, figs. 8-12, 16-20, ?figs. 14-15, pl. 8, figs. 2-7, 14, ?fig. 1, pl. 9, figs. 11-13.

2001 Eoconodontus notchpeakensis (Miller); Lee, p. 451, fig. $7(17,19,24)$.

2002 Eoconodontus notchpeakensis (Miller); Lee, p. 165, pl. 2, figs. 28, 29.

2002 Eoconodontus notchpeakensis (Miller); Lee, p. 27, pl. 2, figs. 17, 19 .

2003 Eoconodontus notchpeakensis (Miller); Heinsalu et al., p. 147, text-figs. 9, 10.

2004c Eoconodontus notchpeakensis (Miller); Dong et al., p. 1204, pl. 2, figs. 1, 3.

2004 Eoconodontus notchpeakensis (Miller); Lee, p. 60, fig. $5(\mathrm{~V}-\mathrm{W})$.

2006 Eoconodontus notchpeakensis (Miller); Miller et al., p. 394, fig. 9 (O, P).

2007 Eoconodontus notchpeakensis (Miller); Landing et al., p. 918, fig. 6 (q, r).

2011 Eoconodontus notchpeakensis (Miller); Miller et al., p. 604 , fig. 7 , K-N.

Description.-Bimembrate apparatus of rounded and compressed elements. Both elements proclined to erect; basal cavity variable, from moderately large to very deep; cusp short to long, composed of white matter; surface smooth. Rounded element symmetrical or subsymmetrical, oval in cross section, possessing or lacking anterior and posterior keels. Compressed element asymmetrical due to lateral bending of the cusp and to the presence of carina on inner side of the base; cusp strongly compressed laterally, with prominent anterior and posterior keels.

Materials.-226 specimens.

Occurrence.-Known from the Wa'ergang section, where it ranges from the Eoconodontus Zone through the Cordylodus lindstromi Zone (upper part).

Genus Eodentatus Nicoll, 1991

Type species.-Eodentatus bicuspatus Nicoll and Shergold, 1991.

Eodentatus bicuspatus Nicoll and Shergold, 1991

Figure 17.18, 17.19

1991 Eodentatus bicuspatus Nicoll and Shergold, p. 99, fig. 3.

Materials.-Two specimens.

Occurrence.-Known from the Wa'ergang section, where it occurs in the Cordylodus proavus Zone.

Remarks.-The present specimens agree in all respects with those described and illustrated by Nicoll and Shergold (1991). This species is characterized by ramiform elements with two denticles and an elongated ovate base.

Genus Granatodontus Chen and Gong, 1986

Type species.-Granatodontus ani (Wang, 1985).

Granatodontus ani (Wang, 1985)

Figure 18.1-18.29

1983 Hirsutodontus sp. aff. Hirsutodontus primitivus An et al., p. 104, pl. 4, figs. 22-23.

1985 Hirsutodontus primitivus An et al., pl. 1, figs. 1-2.

1985 Hirsutodontus? ani Wang in Chen et al., 1985, p. 92, pl. 26, figs. 4-6.

1986 Granatodontus ani (Wang); Chen and Gong, p. 149, pl. 26, fig. 8, pl. 27, figs. 1-5, 8-10, pl. 28, figs. 13, 14, pl. 31 , fig. 10 , text-fig. 53 .

Figure 15. (1-35) Cordylodus prolindstromi Nicoll, 1991; (1) Panjiazui Formation, Wa'ergang section, GMPKU2535, lateral view; (2) Panjiazui Formation, Wa'ergang section, GMPKU2536, lateral view; (3) Panjiazui Formation, Wa'ergang section, GMPKU2537, lateral view; (4) Panjiazui Formation, Wa'ergang section, GMPKU2538, lateral view; (5) Panjiazui Formation, Wa'ergang section, GMPKU2539, lateral view; (6) Panjiazui Formation, Wa'ergang section, GMPKU2540, lateral view; (7) Panjiazui Formation, Wa'ergang section, GMPKU2541, lateral view; (8) Panjiazui Formation, Wa'ergang section, GMPKU2542, lateral view; (9) Panjiazui Formation, Wa'ergang section, GMPKU2543, lateral view; (10) Panjiazui Formation, Wa'ergang section, GMPKU2544, lateral view; (11) Panjiazui Formation, Wa'ergang section, GMPKU2545, lateral view; (12) Panjiazui Formation, Wa'ergang section, GMPKU2546, lateral view; (13) Panjiazui Formation, Wa'ergang section, GMPKU2547, lateral view; (14) Panjiazui Formation, Wa'ergang section, GMPKU2548, lateral view; (15) Panjiazui Formation, Wa'ergang section, GMPKU2549, lateral view; (16) Panjiazui Formation, Wa'ergang section, GMPKU2550, lateral view; (17) Panjiazui Formation, Wa'ergang section, GMPKU2551, lateral view; (18) Panjiazui Formation, Wa'ergang section, GMPKU2552, lateral view; (19) Panjiazui Formation, Wa'ergang section, GMPKU2553, lateral view; (20) Panjiazui Formation, Wa'ergang section, GMPKU2554, lateral view; (21) Panjiazui Formation, Wa'ergang section, GMPKU2555, lateral view; (22) Panjiazui Formation, Wa'ergang section, GMPKU2556, lateral view; (23) Panjiazui Formation, Wa'ergang section, GMPKU2557, lateral view; (24) Panjiazui Formation, Wa'ergang section, GMPKU2558, lateral view; (25) Panjiazui Formation, Wa'ergang section, GMPKU2559, lateral view; (26) Panjiazui Formation, Wa'ergang section, GMPKU2560, lateral view; (27) Panjiazui Formation, Wa'ergang section, GMPKU2561, lateral view; (28) Panjiazui Formation, Wa'ergang section, GMPKU2562, lateral view; (29) Panjiazui Formation, Wa'ergang section, GMPKU2563, lateral view; (30) Panjiazui Formation, Wa'ergang section, GMPKU2564, lateral view; (31) Panjiazui Formation, Wa'ergang section, GMPKU2565, lateral view; (32) Panjiazui Formation, Wa'ergang section, GMPKU2566, lateral view; (33) Panjiazui Formation, Wa'ergang section, GMPKU2567, lateral view; (34) Panjiazui Formation, Wa'ergang section, GMPKU2568, lateral view; (35) Panjiazui Formation, Wa'ergang section, GMPKU2569, lateral view; Relative scale bar represents $150 \mu \mathrm{m}(\mathbf{1 - 3}, \mathbf{5 - 2 3}, \mathbf{2 5}-\mathbf{2 7}, \mathbf{3 0}-\mathbf{3 5}), 137 \mu \mathrm{m}(\mathbf{4}, \mathbf{2 4}, \mathbf{2 8})$, $120 \mu \mathrm{m}(29)$. 

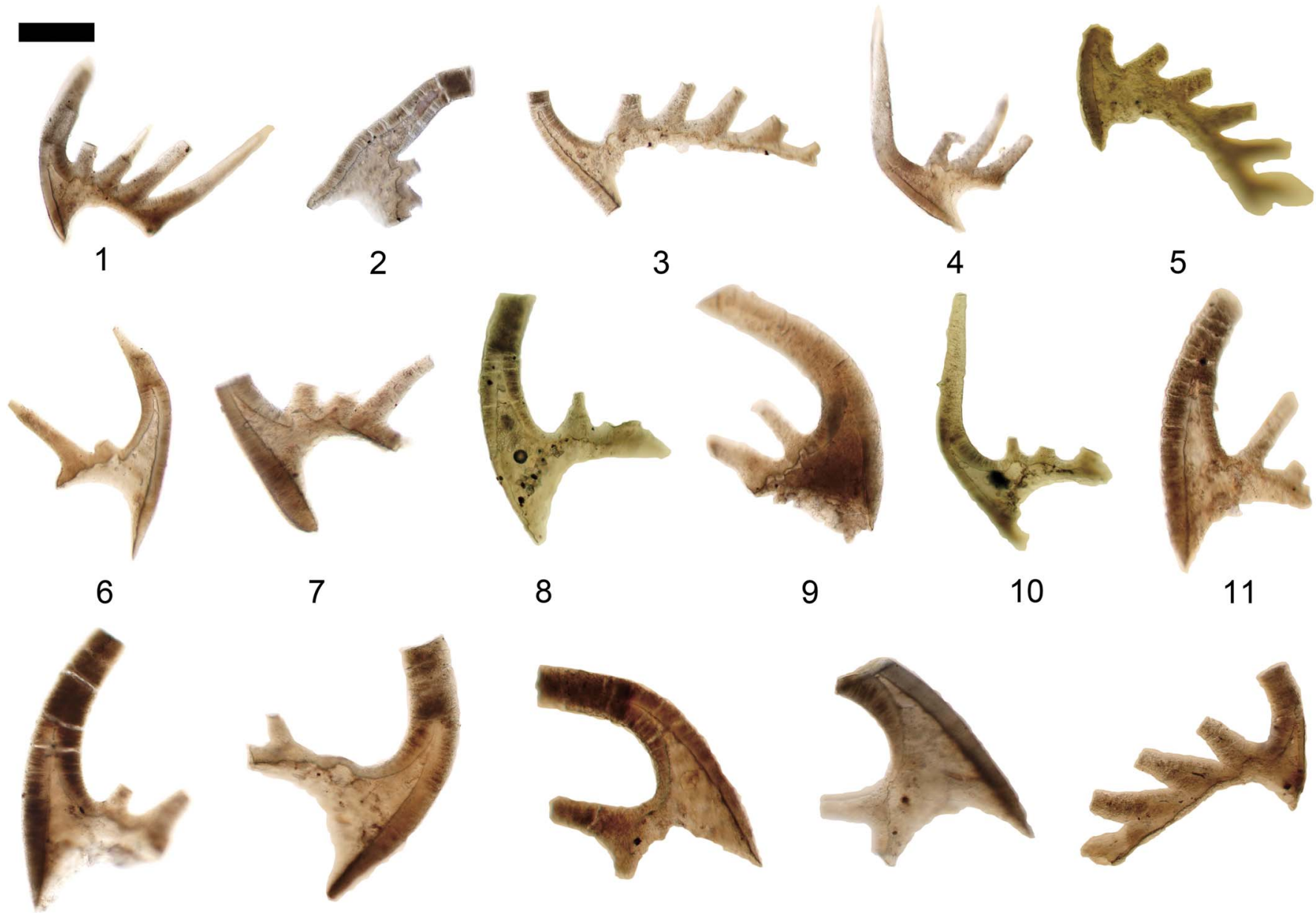

7

8

9

10

11

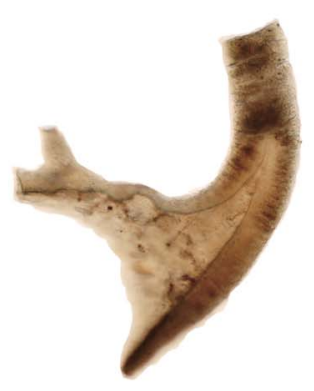

13

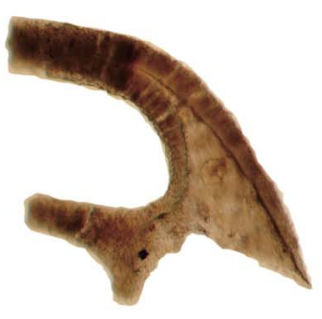

14

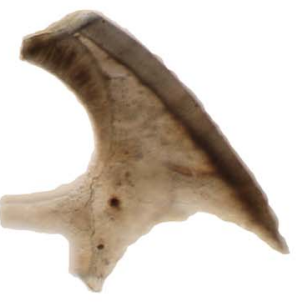

15

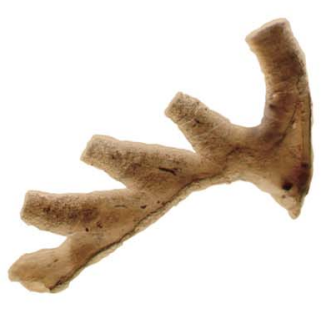

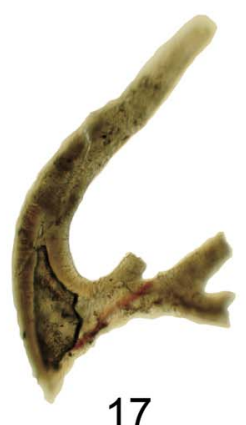

17

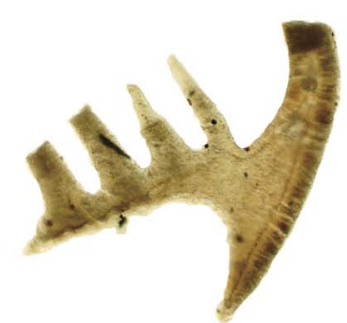

18

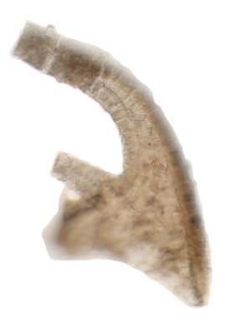

19

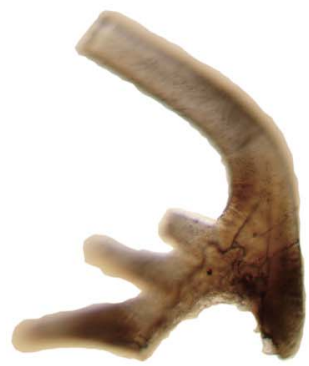

20

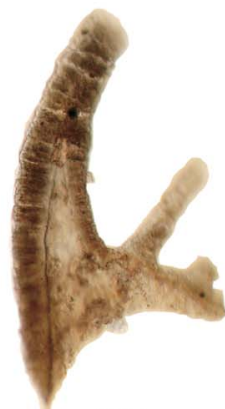

25

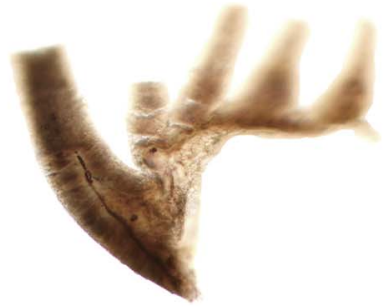

21

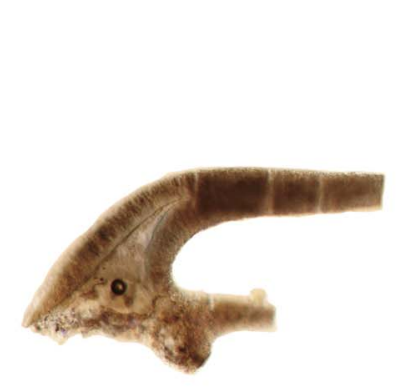

22

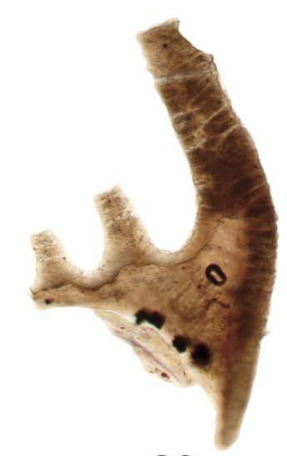

23

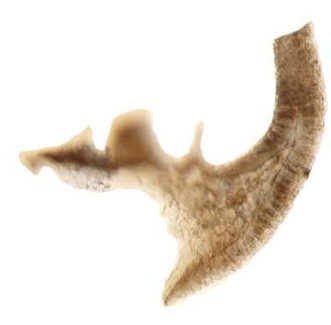

24

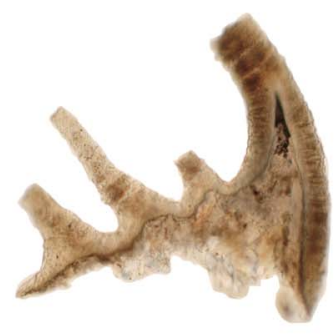

26 
2000 Hirsutodontus ani Wang; Dubinina, p. 186, pl. 6, fig. 1a. 2002 Granatodontus ani (Wang); Lee, p. 165, pl. 2, fig. 13.

2004 Granatodontus ani (Wang); Lee, p. 60, fig. 5 (P).

2004 Granatodontus ani (Wang); Wu and Dong, p. 230, pl. 1, figs. 1-4.

2008 Granatodontus ani (Wang); Lee, p. 228, fig. 1 (3-4), p. 229, pl. 1, fig. 1.

2008 Granatodontus asymmetrica Lee, p. 229, pl. 1, figs. 2, 3.

2008 Granatodontus muliticorrugata Lee, p. 229, pl. 1, figs. 4-6.

2009 Granatodontus ani (Wang); Lee et al., p. 423, fig. 7 (19), p. 425 , fig. 8 (2).

Description.-Coniform elements, erect to proclined and symmetrical, oval in cross section. Base large. Basal cavity large and deep, with apex extending beyond the point of flexure of cusp. The surface of the whole element is ornamented with numerous tiny nodes, rarely with a few tiny spines, except for the apex.

\section{Materials.-80 specimens.}

Occurrence.-Known from Wangcun section where it ranges from the Westergaardodina cf. calix-Prooneotodus rotundatus Zone through the Eoconodontus Zone.

Remarks.-Chen and Gong (1986) suggested that Granatodontus ani (Wang, 1985) is a paraconodont, based on its large basal cavity and lack of white matter. However, histological investigation verifies $G$. ani is a euconodont (Wu and Dong, 2004; Murdock et al., 2013). Conodont elements with conspicuous surface ornamentation, such as spines or nodes, should all be considered to be euconodonts rather than paraconodonts. This generalization can be made without histological study, based on a hypothesis proposed by Bengtson (1976).

\section{Genus Hirsutodontus Miller, 1969}

Type species.—Hirsutodontus hirsutus Miller, 1969.

Hirsutodontus nodus (Zhang and Xiang in An et al., 1983) Figure 19.4-19.13

1983 Teridontus nakamurai nodus Zhang and Xiang in An et al., p. 157, pl. 6, figs. 7, 8, text-fig. 14 (19).

1986 Dasytodus nodus (Zhang and Xiang); Chen and Gong, p. 135 , pl. 28 , fig. 10 , pl. 31 , fig. 9 , text-fig. 42 .
1991 Hirsutodontus nodus (Zhang and Xiang); Nicoll and Shergold, figs. 4, 5 (1).

2001 Hirsutodontus nodus (Zhang and Xiang); Lee, p. 449, fig. $6(19,26)$, p. 451, fig. 7 (3).

2002 Teridontus nodus (Zhang and Xiang); Lee, p. 27, pl. 2, fig. 20.

2002 Hirsutodontus nodus (Zhang and Xiang); Lee, p. 165, pl. 2, fig. 14.

2004 Hirsutodontus nodus (Zhang and Xiang); Lee, p. 60, fig. $5(\mathrm{~S}, \mathrm{X})$.

Materials._-20 specimens.

Occurrence.-Known from the Wangcun and Wa'ergang sections, where it occurs in the Eoconodontus Zone.

Remarks.-An et al. (1983) erected a new subspecies Teridontus nakamurai nodus Zhang and Xiang. Chen and Gong (1986) assigned this subspecies to Dasytodus. Having examined the published material and the new material from Hunan, we agree with Nicoll and Shergold (1991) that T. nakamurai nodus should be assigned to Hirsutodontus rather than Dasytodus. The morphological difference between Dasytodus transmutatus and Hirsutodontus nodus has been fully elucidated by Nicoll and Shergold (1991). The surface of the element of $H$. nodus is ornamented with only a few tiny nodes, so it differs from Hirsutodontus hirsutus Miller.

Genus Hispidodontus Nicoll and Shergold, 1991

Type species.—Hispidodontus discretus Nicoll and Shergold, 1991.

Hispidodontus resimus Nicoll and Shergold, 1991 Figure 19.17-19.19

1991 Hispidodontus resimus Nicoll and Shergold, p. 107, figs. 14, 15, 16 (1-2).

Materials._Three specimens.

Occurrence.-Known from the Wangcun section, where it occurs in the Westergaardodina cf. calix-Prooneotodus rotundatus Zone.

Remarks.-The specimens at hand agree well with Hispidodontus resimus described and figured by Nicoll and Shergold (1991). They are all S elements.

Figure 16. Conodont images using oil immersion techniques (Dong et al., 2005c) with Differential Interference Contrast (Nomarski) illumination, showing the shapes of the biapical basal cavities. (1-26) Cordylodus prolindstromi Nicoll, 1991; (1) the same specimen as Figure 15.10; (2) the same specimen as Figure 15.4; (3) the same specimen as Figure 15.5; (4) the same specimen as Figure $15.6 ;(\mathbf{5})$ the same specimen as Figure 15.11; (6) the same specimen as Figure 15.13; (7) the same specimen as Figure $15.14 ;(\mathbf{8})$ the same specimen as Figure 15.15; (9) the same specimen as Figure 15.16; (10) the same specimen as Figure 15.17; (11) the same specimen as Figure 15.19; (12) the same specimen as Figure 15.20; (13) the same specimen as Figure 15.21; (14) the same specimen as Figure 15.22; (15) the same specimen as Figure 15.23; (16) the same specimen as Figure 15.25; (17) the same specimen as Figure 15.26; (18) the same specimen as Figure 15.27; (19) the same specimen as Figure 15.28; (20) the same specimen as Figure 15.29; (21) the same specimen as Figure 15.30; (22) the same specimen as Figure 15.31; (23) the same specimen as Figure 15.32; (24) the same specimen as Figure 15.33; (25) the same specimen as Figure 15.34; (26) the same specimen as Figure 15.35. Relative scale bar represents $168 \mu \mathrm{m}(\mathbf{1}, \mathbf{4}), 149 \mu \mathrm{m}(\mathbf{2}, \mathbf{3}, \mathbf{6}, \mathbf{1 0}, \mathbf{1 2}, \mathbf{1 7}, \mathbf{1 8}, \mathbf{2 1}, \mathbf{2 2}, \mathbf{2 4}), 121 \mu \mathrm{m}(\mathbf{5}, \mathbf{8}, \mathbf{1 3}, \mathbf{1 6}, \mathbf{2 6})$, $109 \mu \mathrm{m}(\mathbf{7}, \mathbf{1 4}, \mathbf{1 9}), 134 \mu \mathrm{m}(\mathbf{9}, \mathbf{1 1}, \mathbf{2 3}, \mathbf{2 5}), 98 \mu \mathrm{m}(\mathbf{1 5}), 101 \mu \mathrm{m}(\mathbf{2 0})$. 


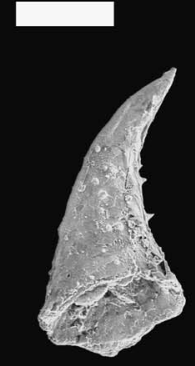

1

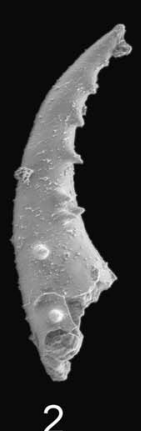

2

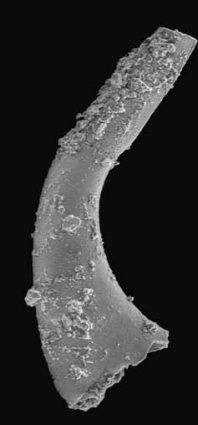

3

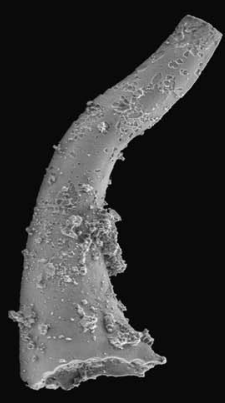

4

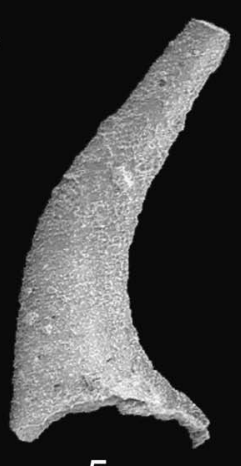

5

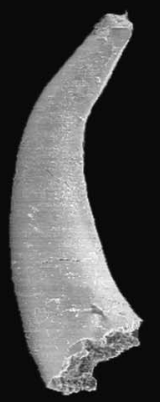

6
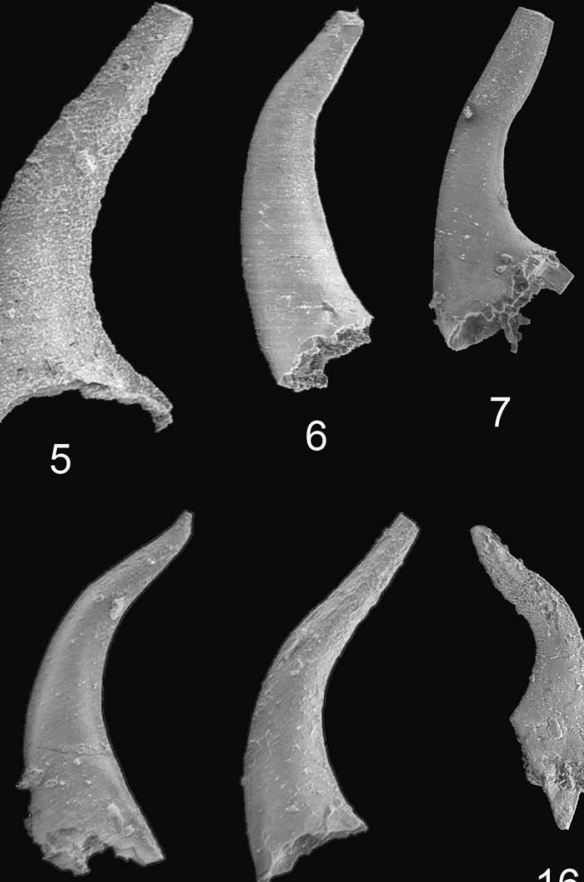

14

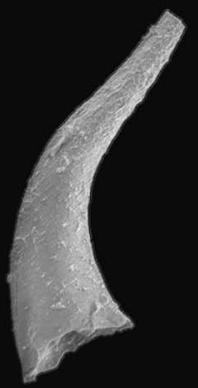

15

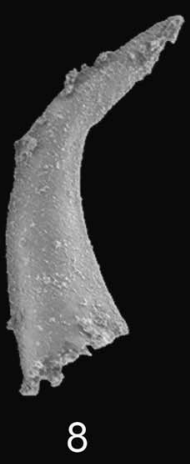

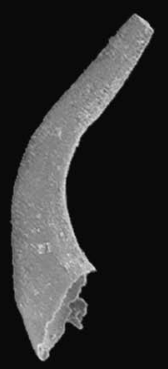

9

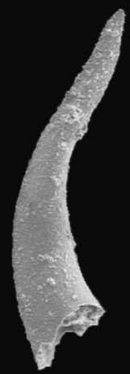

10

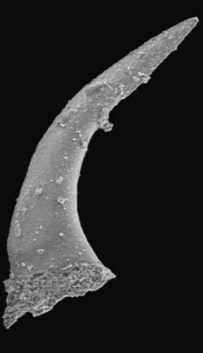

11

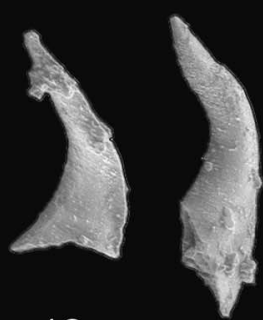

12

13

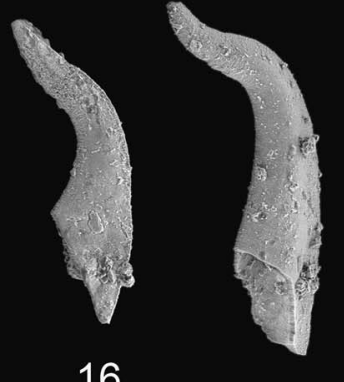

16

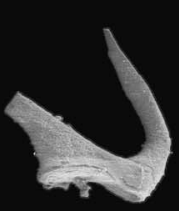

18

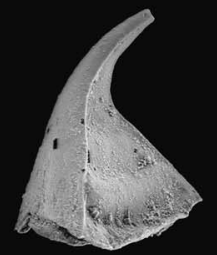

23

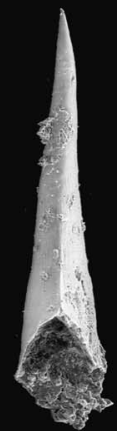

26

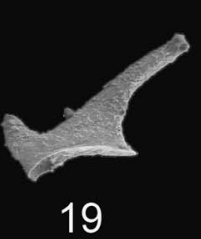

19

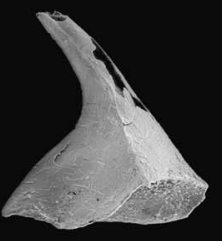

24

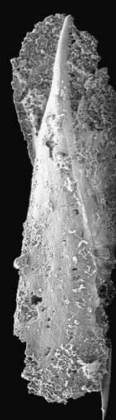

27
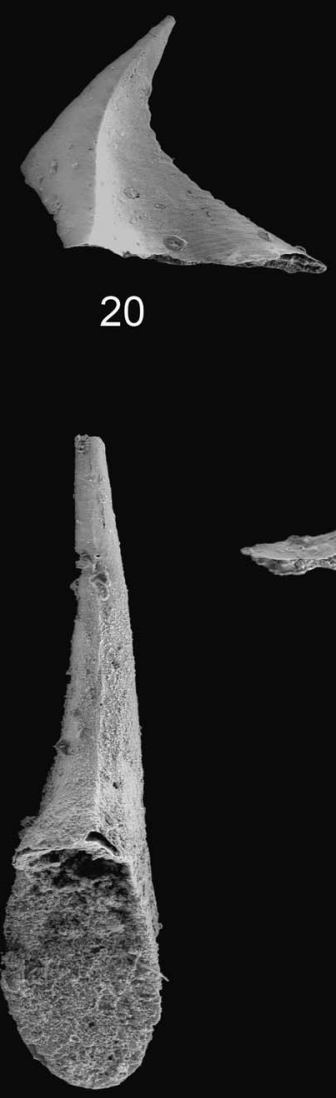

28
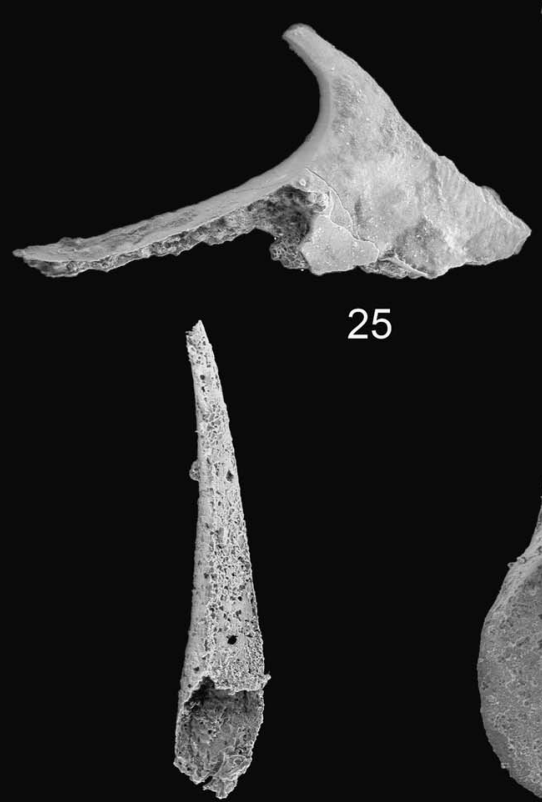

29
25

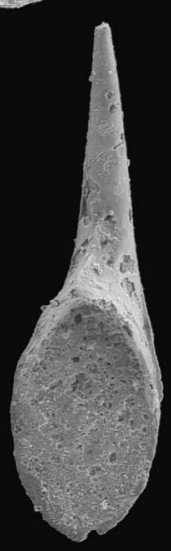

30

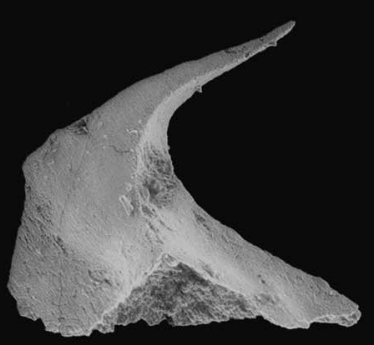

22 
Genus Iapetognathus Landing, 1982

Type species.—Pravognathus aengensis Lindström, 1955.

Iapetognathus aengensis (Lindström 1955)

Figure 20.11-20.17

1955 Pravognathus aengensis Lindström, p. 585, pl. 5. figs. 10-13.

1982 Iapetognathus preaengensis Landing in Fortey et al., p. 124-126, text-figs. 6 (B, C), 8 (B, C, H).

1986 Iapetognathus preaengensis Landing; Landing, Barnes, and Stevens, p. 1934, pl. 1, fig. 8.

1986 Iapetognathus sp. Kaljo et al., pl. 3, fig. 13.

1987 Iapetognathus aengensis (Lindström); Olgun, p. 60, fig. 30.

1988 Iapetognathus preaengensis Landing; Barnes, fig. 13cc only (not fig. $13 \mathrm{y}, \mathrm{z}, \mathrm{aa}, \mathrm{bb}, \mathrm{dd}$, ee). (part)

1988 Iapetognathus preaengensis Landing; Kaljo et al., figs. 4f, $5 f$.

1988 Iapetognathus sp. Kaljo et al., figs. 4bb, 5 bb only.

1993 Iapetognathus preaengensis Landing; Landing, p. 11, fig. $8(1, ? 2)$.

1993 Iapetognathus sp. aff. I. preaengensis Landing; Fåhraeus and Roy, pl. 2, fig. 26 only.

1996 Iapetognathus aengensis (Lindström); Löfgren, p. 173, fig. $8(\mathrm{G}, \mathrm{K})$.

1999 Iapetognathus aengensis (Lindström); Nicoll et al., p. 44 , pl. 1, figs. $1-5$, pl. 2 , figs. $1-4$, pl. 3 , figs. $1-4$, pl. 4, figs. 1-3, pl. 5, figs. 1-3.

2003 Iapetognathus aengensis (Lindström); Heinsalu et al., p. 147, text-fig. 5 (26-30).

2012 Iapetognathus aengensis (Lindström); Terfelt et al., p. 230, fig. 2, A-E.

Materials.—Five specimens.

Occurrence.-Known only from the Wa'ergang section, where it occurs in the Cordylodus angulatus Zone (lower part).

Remarks.-Nicoll et al. (1999) diagnosed multimembrate apparatus in which six element types have been identified, i.e., $\mathrm{Sc}, \mathrm{Sb}, \mathrm{Sd}, \mathrm{Xb}, \mathrm{Pb}$, and $\mathrm{Pa}$ elements. However, only five elements of Iapetognathus aengensis have been recovered from Hunan, and all are $\mathrm{S}$ elements.
Iapetognathus fluctivagus Nicoll et al., 1999

Figure 20.18-20.24

1970 New Genus A Miller, p. 110, pl. 1, figs. 32-34, text-fig. 11E.

1982 New Genus 2 (cordylodid) Miller et al., text-figs. 5, 6.

1987 Iapetognathus preaengesis Landing; Miller, fig. 3.

1988 Iapetognathus preaengesis Landing; Barnes, fig. 13z, aa only.

1995 Iapetognathus n. sp. Taylor and Repetski, p. 135.

1995 Iapetognathus n. sp. 1 Miller and Stitt, p. 108.

1995 Iapetognathus n. sp. 1 Miller and Taylor, p. 111.

1999 Iapetognathus fluctivagus Nicoll et al., p. 46, pl. 6, figs. $1-5$, pl. 7, figs. $1-4$, pl. 8, figs. 1-2, pl. 9, figs. 17, pl. 10, figs. 1-6, pl. 11, figs. 1-6.

2004c Iapetognathus fluctivagus Nicoll et al.; Dong et al., p. 1205, pl. 3, figs. 1-3.

non 2007 Iapetognathus fluctivagus Nicoll et al.; Pyle et al., 1656, p. 1733, fig. $10(8,9)$.

2012 Iapetognathus? fluctivagus Nicoll et al.; Terfelt et al., p. 230, fig. 2, F-G, H-K.

Materials.-Three specimens.

Occurrence.-Known only from the Wa'ergang section, where it occurs in the upper part of the Cordylodus lindstromi Zone.

Remarks.-Although Iapetognathus fluctivagus is widespread in North America, specimens of it are very rare in China. So far, only three specimens belonging to $\mathrm{P}$ elements have been recovered in western Hunan, South China, by means of sampling and processing on an extremely large scale. Cooper et al. (2001) established a stratotype for the base of the Ordovician based on the FAD of this species at Green Point in Newfoundland, Canada.

\section{Iapetognathus jilinensis Nicoll et al., 1999} Figure 20.25-20.28

1995 Iapetognathus n. sp. A Nowlan and Nicoll, p. 115-116.

1999 Iapetognathus jilinensis Nicoll et al., p. 48, pl. 12, figs. 1a-4f, pl. 13, figs. 1a-3f, pl. 14, figs. 1a-4b.

Figure 17. (1, 2) Dasytodus transmutatus (Xu and Xiang, 1983); (1) Shenjiawan Formation, Wangcun section, GMPKU2570, lateral view; (2) Shenjiawan Formation, Wa'ergang section, GMPKU2571, lateral view; (3-17) Eoconodontus notchpeakensis Miller, 1980; (3) Shenjiawan Formation, Wangcun section, GMPKU2572, lateral view; (4) Shenjiawan Formation, Wangcun section, GMPKU2573, lateral view; (5) Shenjiawan Formation, Wa'ergang section, GMPKU2574, lateral view; (6) Shenjiawan Formation, Wa'ergang section, GMPKU2575, lateral view; (7) Shenjiawan Formation, Wa'ergang section, GMPKU2576, lateral view; (8) Shenjiawan Formation, Wa'ergang section, GMPKU2577, lateral view; (9) Shenjiawan Formation, Wa'ergang section, GMPKU2578, lateral view; (10) Shenjiawan Formation, Wa'ergang section, GMPKU2579, lateral view; (11) Shenjiawan Formation, Wa'ergang section, GMPKU2580, lateral view; (12) Shenjiawan Formation, Wa'ergang section, GMPKU2581, lateral view; (13) Shenjiawan Formation, Wa'ergang section, GMPKU2582, lateral view; (14) Shenjiawan Formation, Wa'ergang section, GMPKU2583, lateral view; (15) Shenjiawan Formation, Wa'ergang section, GMPKU2584, lateral view; (16) Shenjiawan Formation, Wa'ergang section, GMPKU2585, lateral view; (17) Shenjiawan Formation, Wa'ergang section, GMPKU2586, lateral view; (18, 19) Eodentatus bicuspatus Nicoll and Shergold, 1991; (18) Shenjiawan Formation, Wa'ergang section, GMPKU2587, ramiform element, lateral view; (19) Shenjiawan Formation, Wa'ergang section, GMPKU2588, ramiform element, lateral view; (20-25) Furnishina bigeminata Dong, 1993; (20) Huaqiao Formation, Wangcun section, GMPKU2589, outer lateral view; (21) Huaqiao Formation, Wangcun section, GMPKU2590, inner lateral view; (22) Huaqiao Formation, Wangcun section, GMPKU2591, outer lateral view; (23) Chefu Formation, Wangcun section, GMPKU2592, outer lateral view; (24) Chefu Formation, Wangcun section, GMPKU2593, outer lateral view; (25) Bitiao Formation, Wangcun section, GMPKU2594, lateral view; (26-31) Furnishina dayangchaensis Chen and Gong, 1986; (26) Bitiao Formation, Wangcun section, GMPKU2595, posterior view; (27) Bitiao Formation, Wangcun section, GMPKU2596, cluster; (28) Bitiao Formation, Wangcun section, GMPKU2597, posterior view; (29) Bitiao Formation, Wangcun section, GMPKU2598, oblique posterior view; (30) Shenjiawan Formation, Wa'ergang section, GMPKU2599, posterior view; (31) Shenjiawan Formation, Wa'ergang section, GMPKU2600, oblique posterior view. Relative scale bar represents $126 \mu \mathrm{m}(\mathbf{1}, \mathbf{2 3}), 135 \mu \mathrm{m}(\mathbf{2 - 2 2 ,} \mathbf{2 4 - 3 1})$. 


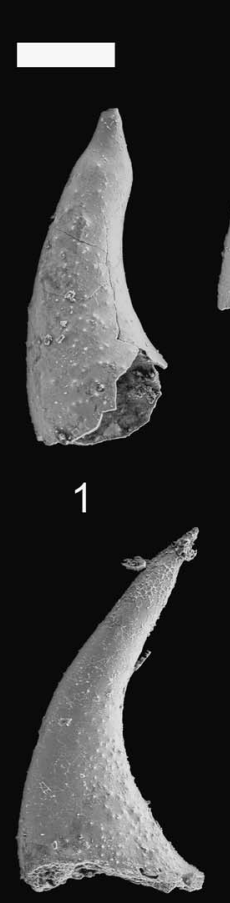

8
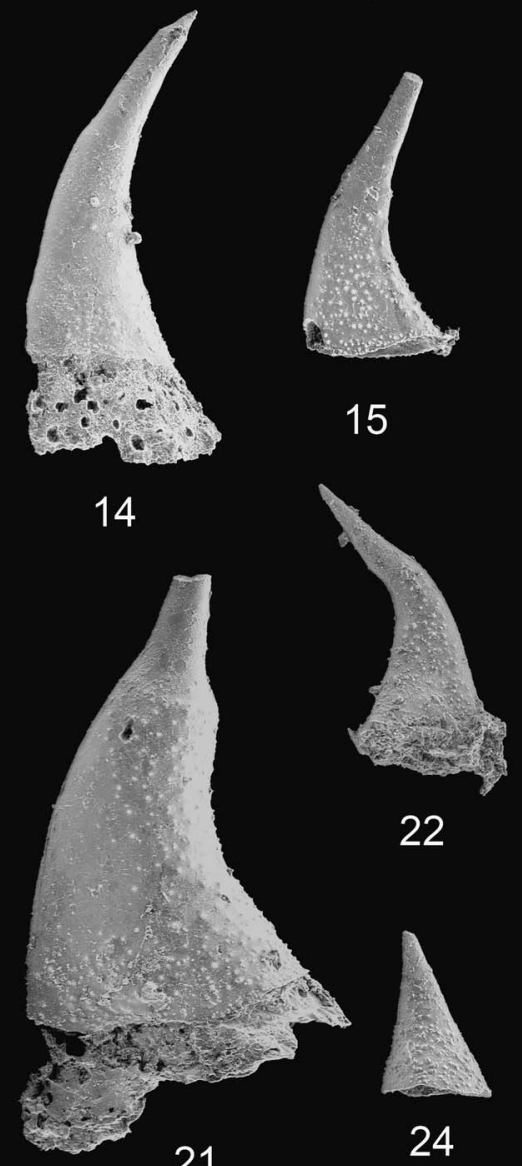

21

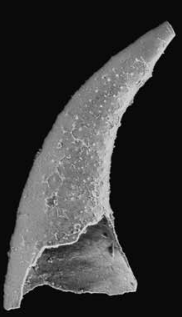

2

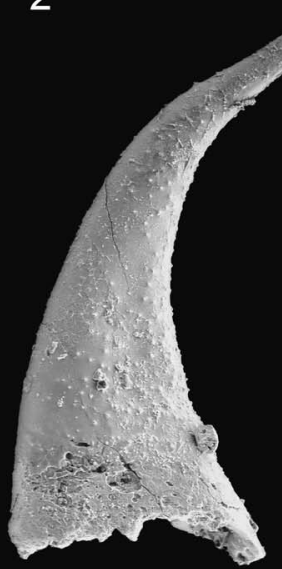

9

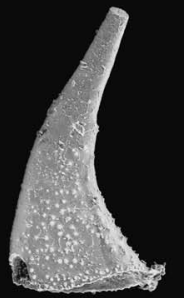

15

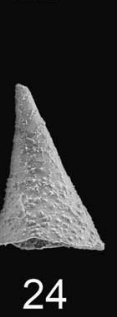

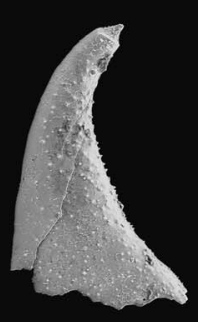

16
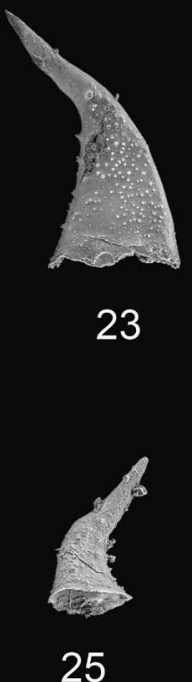

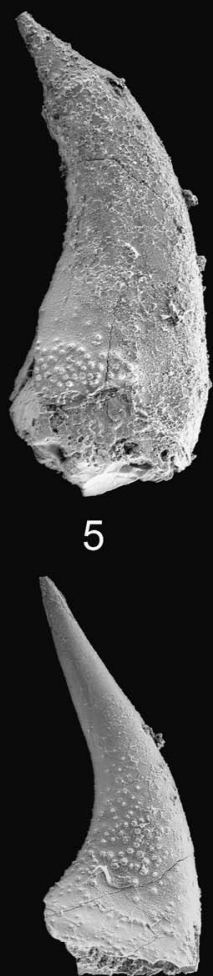

11

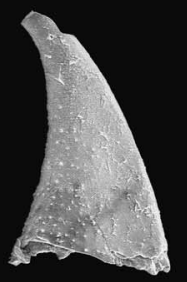

17

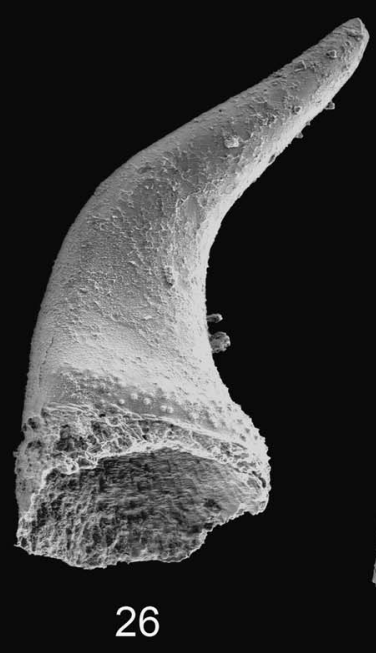

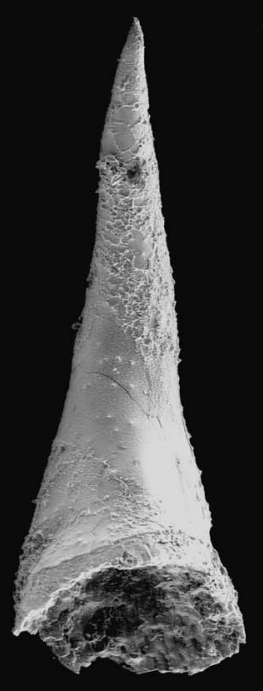

6

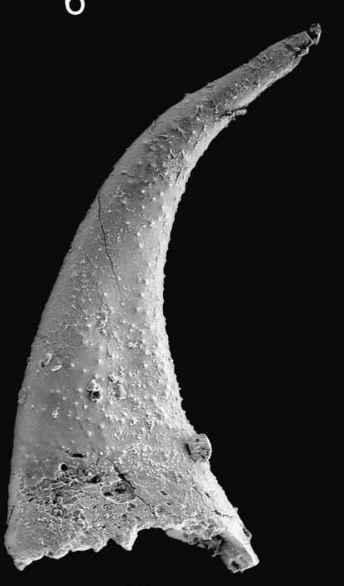

12
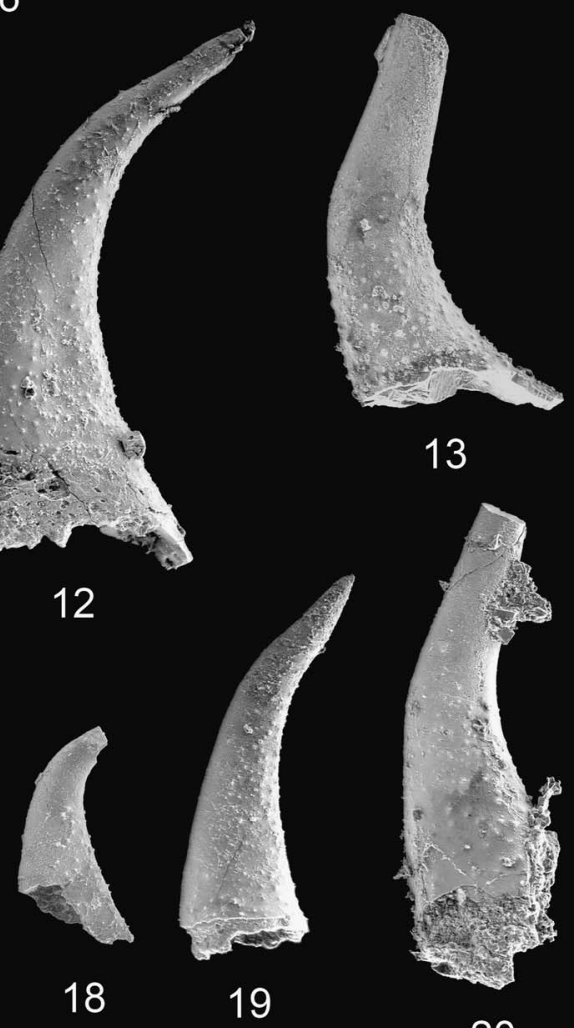

13
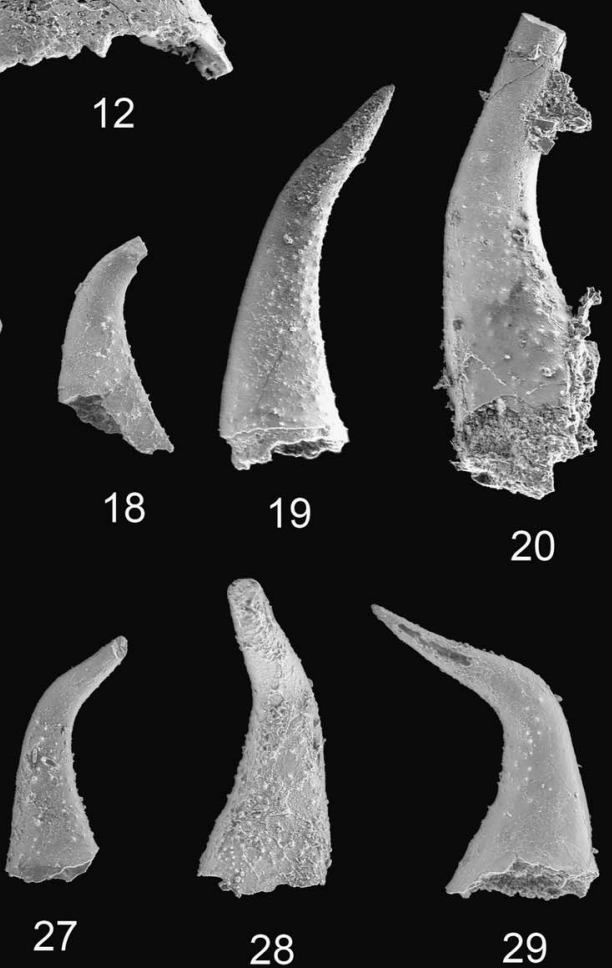
Materials.-Only one specimen.

Occurrence.-Known only from the Wa'ergang section, where it occurs in the Cordylodus lindstromi Zone (Upper Part).

Remarks.-Only a single specimen belonging to S element has been recovered from western Hunan.

Genus Mamillodus Abaimova, 1983

Type species.—Mamillodus tubularis Abaimova, 1983.

Mamillodus ruminatus Dubinina, 2000

Figure 21.7

2000 Mamillodus ruminatus Dubinina, p. 171, pl. 7, figs. 1-6.

Materials.—Only one specimen.

Occurrence.-Known from the Wa'ergang section, where it occurs in the Eoconodontus Zone.

Remarks.-The specimens at hand agree closely with Mamillodus ruminatus. Dubinina indicated it is a paraconodont. Based on its surface ornamentation, however, it is probably a euconodont (Bengtson, 1976).

\section{Genus Millerodontus new genus}

Type species.—Millerodontus intermedius $\mathrm{n}$. gen. $\mathrm{n}$. sp.

Diagnosis.-Coniform euconodont elements, proclined, symmetrical, with rounded cross section. Keels or costae are lacking. Basal cavity is very deep.

Etymology.-In honor of James F. Miller, Missouri State University, USA, the name is composed from Miller and a derivative of Greek, odon, tooth.

Millerodontus intermedius new genus new species

Figures 21.13, 21.14, 21.17-21.19, 22.1-22.8

Diagnosis.-As for genus.

Description.-Moderate to small coniform elements, proclined, and symmetrical. The apex is pointed. Both anterior and posterior sides are rounded, without keels or costae. Basal cavity is very deep, the apex of which extends nearly to the tip of the element. The cross section is circular. Crown tissues and the phenomenon of regeneration could be observed at the apical portion of element.

Etymology._intermedius, Latin, intermediate.

Types.-Holotype: GMPKU2252 from the Proconodontus tenuiserratus Zone, Shenjiawan Formation, Wa'ergang section, Wa'ergang village, Taoyuan county, Hunan Province.

Materials.—10 specimens.

Occurrence.-Known from the Wa'ergang and Wangcun sections, where it ranges from the Proconodontus tenuiserratus Zone through the Cordylodus proavus Zone.

Comparision.-In gross morphology, Millerodontus intermedius n. gen. n. sp. resembles Prooneotodus rotundatus, but it is recognized as euconodont in the light of histological investigation. $M$. intermedius is a representative of the model of early evolution of euconodonts proposed by Bengtson (1976), according to which euconodont elements originated from paraconodonts through acquisition of a crown. M. intermedius is probably the transitional form between $P$. rotundatus and Proconodontus tenuiserratus.

Remarks.-The majority of the specimens which resemble Prooneotodus rotundatus have thick sheaths, just like Miller's interpretation that a thin layer of apatite covers a massive white basal cone (Miller, 1980, p. 31-32). Not all specimens could be investigated by means of the oil immersion technique, and thin sectioning would ruin the specimens. Therefore, the number of specimens of Millerodontus intermedius n. gen. n. sp. is probably much more than ten.

Genus Monocostodus Miller, 1980

Type species.—Acodus sevierensis Miller, 1969.

Monocostodus sevierensis (Miller, 1969)

Figure 21.20-21.23

Figure 18. (1-29) Granatodontus ani (Wang, 1985); (1) Bitiao Formation, Wangcun section, GMPKU2652, lateral view; (2) Bitiao Formation, Wangcun section, GMPKU2653, lateral view; (3) Shenjiawan Formation, Wangcun section, GMPKU2654, lateral view; (4) Shenjiawan Formation, Wangcun section, GMPKU2655, lateral view; (5) Shenjiawan Formation, Wangcun section, GMPKU2656, lateral view; (6) Shenjiawan Formation, Wangcun section, GMPKU2657, posterior view; (7) Shenjiawan Formation, Wangcun section, GMPKU2658, lateral view; (8) Shenjiawan Formation, Wangcun section, GMPKU2659, lateral view; (9) Shenjiawan Formation, Wangcun section, GMPKU2660, lateral view; (10) Shenjiawan Formation, Wangcun section, GMPKU2661, lateral view; (11) Shenjiawan Formation, Wangcun section, GMPKU2662, lateral view; (12) Shenjiawan Formation, Wangcun section, GMPKU2663, lateral view; (13) Shenjiawan Formation, Wangcun section, GMPKU2664, lateral view; (14) Shenjiawan Formation, Wangcun section, GMPKU2665, lateral view; (15) Shenjiawan Formation, Wangcun section, GMPKU2666, lateral view; (16) Shenjiawan Formation, Wangcun section, GMPKU2667, lateral view; (17) Shenjiawan Formation, Wangcun section, GMPKU2668, lateral view; (18) Shenjiawan Formation, Wangcun section, GMPKU2669, lateral view; (19) Shenjiawan Formation, Wangcun section, GMPKU2670, lateral view; (20) Shenjiawan Formation, Wangcun section, GMPKU2671, lateral view; (21) Shenjiawan Formation, Wangcun section, GMPKU2672, lateral view; (22) Shenjiawan Formation, Wangcun section, GMPKU2673, lateral view; (23) Shenjiawan Formation, Wangcun section, GMPKU2674, lateral view; (24) Shenjiawan Formation, Wangcun section, GMPKU2675, lateral view; (25) Shenjiawan Formation, Wangcun section, GMPKU2676, lateral view; (26) Shenjiawan Formation, Wangcun section, GMPKU2677, lateral view; (27) Shenjiawan Formation, Wangcun section, GMPKU2678, lateral view; (28) Shenjiawan Formation, Wangcun section, GMPKU2679, lateral view; (29) Shenjiawan Formation, Wangcun section, GMPKU2680, lateral view. Relative scale bar represents 154 $\mu \mathrm{m}(\mathbf{1 , 2 , 5 - 2 4 , 2 6 , 2 8 , ~ 2 9 ) ,}$ $144 \mu \mathrm{m}(\mathbf{3}, \mathbf{4}, \mathbf{2 5}), 164 \mu \mathrm{m}(\mathbf{2 7})$. 


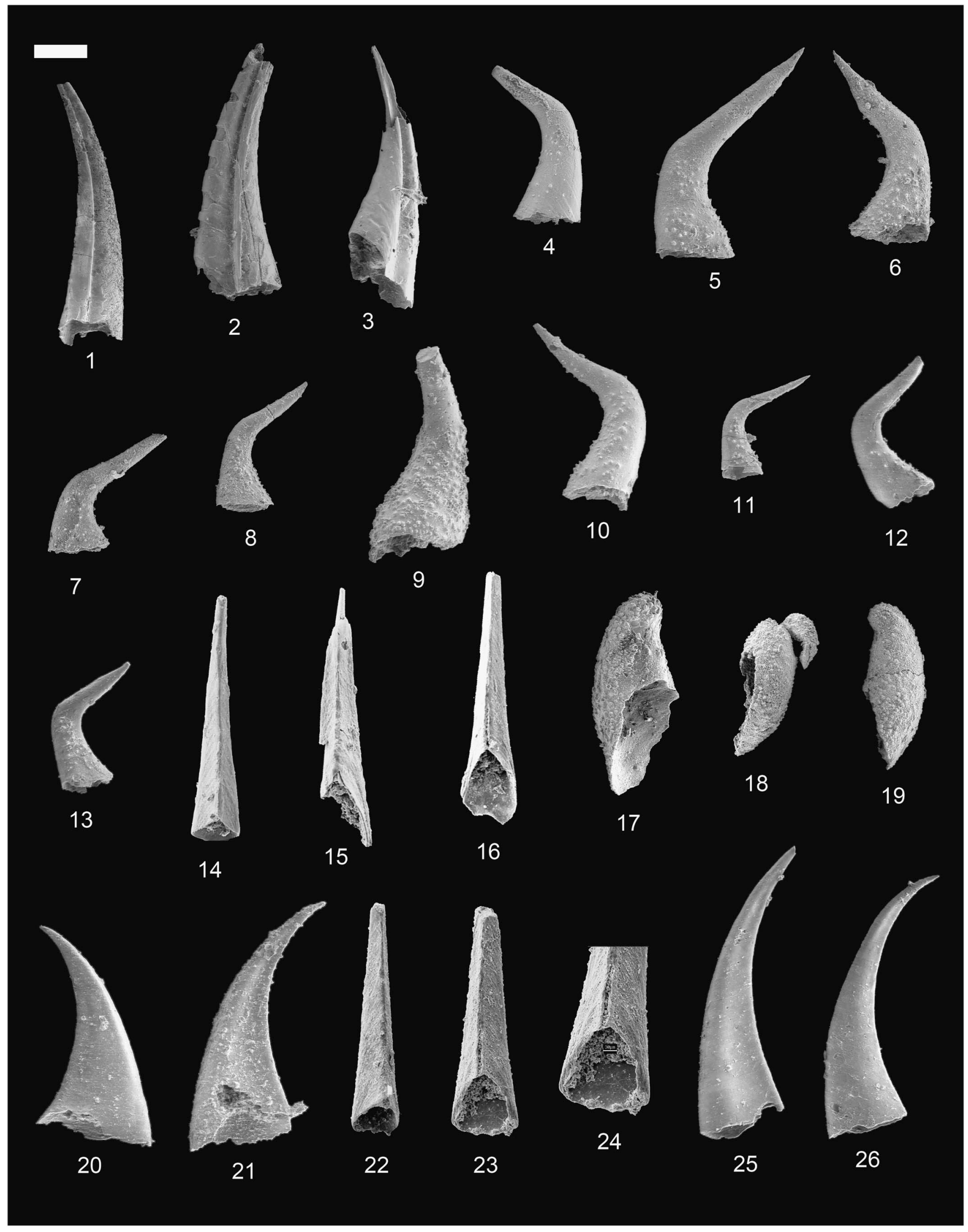


1969 Acodus sevierensis Miller, p. 418, pl. 63, figs. 25-31 (not figs. 21-24, 32). (part)

1969 Acontiodus (Semiacontiodus) unicostatus Miller, p. 421, pl. 64, figs. 19-54 (not figs. 46-48). (part)

1971 Drepanodus simplex Branson and Mehl; Druce and Jones, p. 74, text-fig. 24b, pl. 13, figs. 1-4.

1973 Semiacontiodus sevierensis (Miller), Lindström, p. $442-445$.

1980 Monocostodus sevierensis (Miller); Miller, p. 27, pl. 2, figs. 8-9, text-fig. $4 \mathrm{U}$.

1982 Monocostodus sevierensis (Miller); Landing in Fortey et al., p. 123, text-fig. 8 (Q, R).

1983 Monocostodus sevierensis (Miller); An et al., p. 108, pl. 6, figs. 19-23.

1985 Monocostodus sevierensis (Miller); Dong, p. 400, pl. 3, figs. 8, 11.

? 1985 Monocostodus sevierensis (Miller); Wang in Chen et al., p. 93, pl. 25, figs. 9-11, text-fig. 14 (7).

1987 Monocostodus sevierensis (Miller); Dong, p. 163, pl. 1, figs. 26, 32, pl. 2, figs. 1, 2 .

1993 Monocostodus sevierensis (Miller); Landing, p. 6, fig. $4(10,18,19)$.

1996 Drepanodus simplex Branson and Mehl; Lee et al., p. 97, pl. 1, fig. 17.

1998 Monocostodus sevierensis (Miller); Rao and Tortello, p. 43, pl. 1, figs. 13-18.

2000 Drepanodus simplex Branson and Mehl; Zhao et al., p. 198, pl. 9, figs. 1-9.

2000 Monocostodus sevierensis (Miller); Zhao et al., p. 206, pl. 8, figs. 1-7.

2003 Monocostodus sevierensis (Miller); Landing et al., p. 86 , fig. $7(14,18)$.

Description.-Slender coniform elements, erect to reclined, with short base and long cusp. Cross section is circular through base and the aboral half of the cusp, but it becomes extremely laterally compressed through the oral half of cusp. The anterior and posterior sides of the oral half of cusp are keeled. Basal cavity is shallow. The slender cusp is composed entirely of white matter.

\section{$?$ 27, pl. 8, f'igs. 17, 18, pl. 12, fig. 7, pl. 13, figs. 1, 6. (part)

1985 Proconodontus muelleri Miller; Wang, p. 231, pl. 9, Proconodontus muelleri $\mathrm{M}$.
figs. 16-18, pl. 13, fig. 25.

Materials._-12 specimens.

1986 Proconodontus muelleri Miller; Chen and Gong, p. 159, pl. 32, figs. 1, 3, 10, 12-14, 17, pl. 33,
Occurrence.-Known from the Wa'ergang section, where it ranges from the Cordylodus lindstromi Zone (upper part) through the Cordylodus angulatus Zone.

Genus Proconodontus Miller, 1969

Type species._Proconodontus muelleri Miller, 1969.

$$
\text { Proconodontus muelleri Miller, } 1969
$$

Figure 23.8-23.32

1969 Proconodontus mülleri mülleri Miller, p. 437, text-fig. 5H, pl. 66, figs. 30-40.

1970 Proconodontus mülleri mülleri Miller; Miller, pl. 2, fig. 18.

1971 Proconodontus mulleri mulleri Miller; Ethington and Clark, pl. 1, fig. 25.

1971 Coelocerodontus burkei Druce and Jones, p. 61, textfig. 22a (not text-fig. 22e), pl. 11, figs. 9-11 (not figs. 5-8, 12). (part)

? 1973 Proconodontus muelleri Miller; Müller, p. 42, pl. 3, figs. 4-7, ?10 (not fig. 8). (part)

1976 Proconodontus muelleri Miller; Miller and Paden, p. 595 , pl. 1, figs. 4,5 .

1978 Proconodontus muelleri muelleri Miller; Tipnis et al., pl. 1, figs. 13, 17.

1980 Proconodontus muelleri Miller; Miller, p. 29, text-fig. 4C, pl. 1, fig. 7 .

Proconodontus muelleri Miller; Miller in Robison, p. W146, fig. 95 (2a, b).

1982 Proconodontus muelleri muelleri Miller; Fortey et al., p. 125, text-fig. 9 (K).

1982 Proconodontus muelleri Miller; An, p. 141, pl. 12, figs. 8, 9, 11-13, pl. 16, figs. 10, 12.

1983 Proconodontus muelleri Miller; An et al., p. 126, pl. 5, fig. 21 only (not figs. 15, 16, 23, 24). (part)

1985 Proconodontus muelleri Miller; Nowlan, p. 114, fig. 5.1. 1985 Proconodontus muelleri Miller; Wang, p. 231, pl. 2, figs. 16-20 (not fig. 21), pl. 6, figs. 17-19, pl. 7, figs. 10,

Figure 19. (1-3) Gumella cuneata Müller and Hinz, 1991; (1) Huaqiao Formation, Wangcun section, GMPKU2681, lateral view; (2) Huaqiao Formation, Wangcun section, GMPKU2682, lateral view; (3) Chefu Formation, Wangcun section, GMPKU2683, lateral view; (4-13) Hirsutodontus nodus (Zhang and Xiang, 1983); (4) Shenjiawan Formation, Wangcun section, GMPKU2684, lateral view; (5) Shenjiawan Formation, Wangcun section, GMPKU2685, lateral view; (6) Shenjiawan Formation, Wangcun section, GMPKU2686, lateral view; (7) Shenjiawan Formation, Wangcun section, GMPKU2687, lateral view; (8) Shenjiawan Formation, Wangcun section, GMPKU2688, lateral view; (9) Shenjiawan Formation, Wa'ergang section, GMPKU2689, lateral view; (10) Shenjiawan Formation, Wa'ergang section, GMPKU2690, lateral view; (11) Shenjiawan Formation, Wa'ergang section, GMPKU2691, lateral view; (12) Panjiazui Formation, Wa'ergang section, GMPKU2692, lateral view; (13) Panjiazui Formation, Wa'ergang section, GMPKU2693, lateral view; (14-16, 22-24) Huayuanodontus tricornis (Dong, 1993); (14) Chefu Formation, Wangcun section, GMPKU2242, posterior view; (15) Chefu Formation, Wangcun section, GMPKU2694, posterior view; (16) Chefu Formation, Wangcun section, GMPKU2695, posterior view; (22) Chefu Formation, Paibi section, GMPKU2696, posterior view; (23) Chefu Formation, Paibi section, GMPKU2245, posterior view; (24) close-up of (23) posterior view; (17-19) Hispidodontus resimus Nicoll and Shergold, 1991; (17) Bitiao Formation, Wangcun section, GMPKU2697, posterolateral view; (18) Bitiao Formation, Wangcun section, GMPKU2698, broken specimen, outer lateral view; (19) Bitiao Formation, Wangcun section, GMPKU2699, anterolateral view; (20, 21, 25, 26) Lugnathus hunanensis n. gen. n. sp.; (20) Panjiazui Formation, Wa'ergang section, GMPKU2700, lateral view; (21) Panjiazui Formation, Wa'ergang section, GMPKU2701, lateral view; (25) Panjiazui Formation, Wa'ergang section, holotype, GMPKU2702, lateral view; (26) Panjiazui Formation, Wa'ergang section, GMPKU2703, lateral view. Relative scale bar represents $502 \mu \mathrm{m}(\mathbf{1}), 269 \mu \mathrm{m}(\mathbf{2}), 270 \mu \mathrm{m}(\mathbf{3}), 164 \mu \mathrm{m}(\mathbf{4 - 8}, \mathbf{1 0}-\mathbf{1 3}, \mathbf{1 7}, \mathbf{1 8}, \mathbf{2 0}, \mathbf{2 1}, \mathbf{2 5}, \mathbf{2 6}), 157 \mu \mathrm{m}(\mathbf{9}, \mathbf{1 4}, \mathbf{1 9}, \mathbf{2 3}), 146 \mu \mathrm{m}$

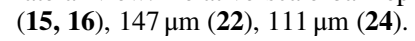




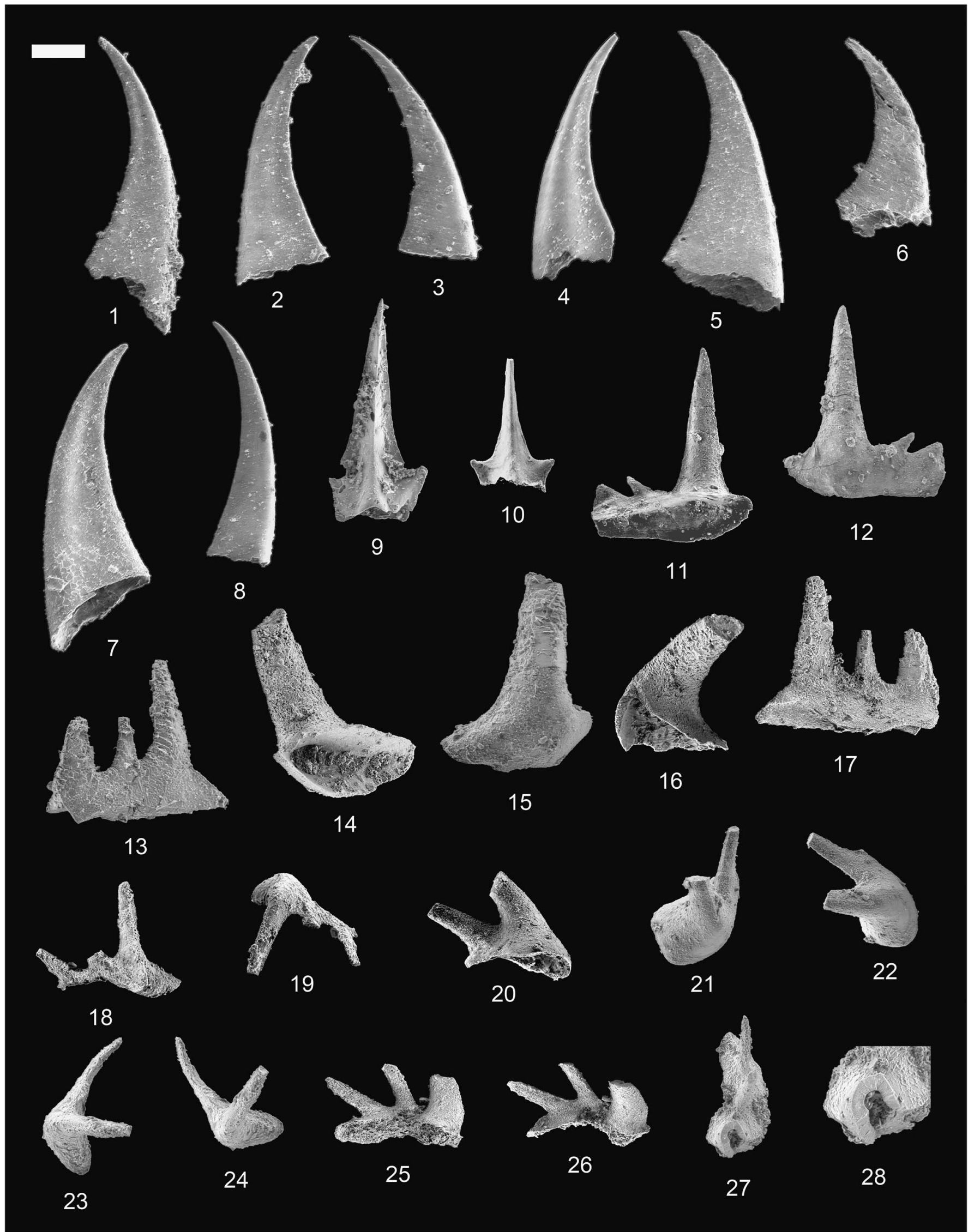


figs. 3-5, 11 (not pl. 19, fig. 6), text-fig. 60 (1-2; 4-6; not 3). (part)

1987 Proconodontus muelleri Miller; Dong, p. 169, pl. 1, figs. 3-5, text-figs. 3B, C, 4D.

1987 Proconodontus muelleri Miller; An, p. 109, pl. 2, figs. 4, 17.

1987 Proconodontus aff. muelleri Miller; An, p. 110, pl. 2, figs. 19-21.

1988 Proconodontus muelleri Miller; Andres, p. 125, pl. 10, figs. $1-8$, pl. 11, figs. $1-8$, pl. 12 , figs. $1-4$, text-figs. 20-25.

1988 Proconodontus muelleri Miller; Lee and Lee, pl. 2, figs. 27-29.

1991 Proconodontus muelleri Miller; Müller and Hinz, p. 56, pl. 42, figs. 1-16, text-figs. 22B, C.

1993 Proconodontus muelleri Miller; Landing, p. 6, fig. 4 (5).

1996 Proconodontus muelleri Miller; Lee et al., p. 97, pl. 1, fig. 3.

? 2000 Proconodontus muelleri Miller; Dubinina, p. 194, pl. 7 , fig. 7 .

2001 Proconodontus muelleri Miller; Lee, p. 451, fig. 7.15.

2002 Proconodontus muelleri Miller; Lee, p. 165, pl. 2, fig. 26.

2002 Proconodontus muelleri Miller; Lee, p. 27, pl. 2, fig. 15.

2004 Proconodontus muelleri Miller; Lee, p. 60, fig. 5 (H).

2006 Proconodontus muelleri Miller; Miller et al., p. 394, fig. 9 (S).

2007 Proconodontus muelleri Miller; Landing et al., p. 918, fig. $6(\mathrm{n}, \mathrm{o})$.

2009 Proconodontus muelleri Miller; Lee et al., p. 423, fig. 7 (8).

2011 Proconodontus muelleri Miller; Miller et al., p. 604, fig. 7, I, J.

Description.-Coniform elements, moderate to large, proclined and symmetrical or nearly so. The cross section is circular at the apical portion and it changes into an oval to moderately compressed outline toward the base. Basal cavity is very large and deep, with the apex extending nearly to the tip of it. Both anterior and posterior edges are characterized by sharp keels of variable extent. Usually, the posterior keel is more conspicuous and extends from the tip to the base, while the anterior keel extends from the tip to variable distances down toward the base of the element. Regeneration of the tip is often observed at the apical portion of the element.

Materials._-200 specimens.

Occurrence.-Known from the Wangcun and Wa'ergang sections, where it ranges from the Proconodontus Zone through the Eoconodontus Zone.

Remarks.-Miller (1980) believed white matter is lacking in Proconodontus. However, Müller and Hinz (1991) found white matter in the keel and in the regenerated part of the tip. Later, they verified this observation by histological investigation (Müller and Hinz, 1998, p. 108-110, fig. 18.3). Indeed, our histological study on many specimens of Proconodontus muelleri recovered from Hunan, South China also verified this conclusion (Xi-ping Dong and Philip C. J. Donoghue, unpublished data).

\section{Proconodontus posterocostatus Miller, 1980}

Figure 24.1, 24.2

1971 Coelocerodontus burkei Druce and Jones, p. 61, pl. 11, figs. 7, 8 (not figs. 5, 6, 9-12). (part)

1980 Proconodontus posterocostatus Miller, p. 30, textfig. 4B, pl. 1, figs. 4-6.

non 1982 Proconodontus posterocostatus Miller; An, p. 142, pl. 12, figs. 3, 4, 6, 7, 10 .

1986 Proconodontus posterocostatus Miller; Chen and Gong, p. 161, pl. 25, figs. 1, 6, pl. 30, figs. 1, 3-4, 8-13, pl. 32, fig. 8, pl. 33, figs. 7, 9 (not pl. 19, fig. 16), text-fig. 61 (1, 3-8, not 2). (part)

2002 Proconodontus posterocostatus Miller; Lee, p. 165, pl. 2, fig. 25.

2002 Proconodontus posterocostatus Miller; Lee, p. 27, pl. 2, fig. 12.

2004c Proconodontus posterocostatus Miller; Dong et al., pl. 1, fig. 3.

2004c Proconodontus serratus Miller; Dong et al., pl. 1, fig. 11.

? 2009 Proconodontus posterocostatus Miller; Lee et al., p. 423 , fig. $7(7,9)$.

Figure 20. (1-8) Lugnathus hunanensis n. gen. n. sp.; (1) Panjiazui Formation, Wa'ergang section, GMPKU2704, lateral view; (2) Panjiazui Formation, Wa'ergang section, GMPKU2705, lateral view; (3) Panjiazui Formation, Wa'ergang section, GMPKU2706, lateral view; (4) Panjiazui Formation, Wa'ergang section, GMPKU2707, lateral view; (5) Panjiazui Formation, Wa'ergang section, GMPKU2708, lateral view; (6) Panjiazui Formation, Wa'ergang section, GMPKU2709, lateral view; (7) Panjiazui Formation, Wa'ergang section, GMPKU2710, lateral view; (8) Panjiazui Formation, Wa'ergang section, GMPKU2711, lateral view; (9, 10) Hunanognathus tricuspidatus Dong, 1993; (9) Huaqiao Formation, Wangcun section, GMPKU2712, posterior view; (10) Huaqiao Formation, Wangcun section, GMPKU2141, posterior view; (11-17) Iapetognathus aengesis (Lindström, 1955); (11) Panjiazui Formation, Wa'ergang section, GMPKU2713, S element, aboral view; (12) The same specimen, anterior view; (13) Panjiazui Formation, Wa'ergang section, GMPKU2714, S element, anterior view; (14) Panjiazui Formation, Wa'ergang section, GMPKU2715, S element, aboral view; (15) The same specimen, anterior view; (16) Panjiazui Formation, Wa'ergang section, GMPKU2716, S element, oblique aboral-posterior view; (17) Panjiazui Formation, Wa'ergang section, GMPKU2717, S element, anterior view; (18-24) Iapetognathus fluctivagus Nicoll, Miller, Nowlan, Repetski and Ethington, 1999; (18) Panjiazui Formation, Wa'ergang section, GMPKU2718, P element, anterior view; (19) the same specimen, oral view; (20) Panjiazui Formation, Wa'ergang section, GMPKU2719, P element, oblique aboral-posterior view; (21) the same specimen, oblique lateral view; (22) the same specimen, oblique lateral view; (23) Panjiazui Formation, Wa'ergang section, GMPKU2720, P element, outer lateral view; (24) the same specimen, oblique anterior view; (25-28) Iapetognathus jilinensis Nicoll, Miller, Nowlan, Repetski and Ethington, 1999; (25) Panjiazui Formation, Wa'ergang section, GMPKU2721, S element, oblique aboral-posterior view; (26) the same specimen, posterior view; (27) the same specimen, oblique oral-lateral view; (28) close-up of (27) showing cusp cross-section. Relative scale bar represents $139 \mu \mathrm{m}(\mathbf{1 - 9}, \mathbf{1 1}, \mathbf{2 7})$, 123 $\mu \mathrm{m}$ (10), $72 \mu \mathrm{m}(\mathbf{2 8})$. 

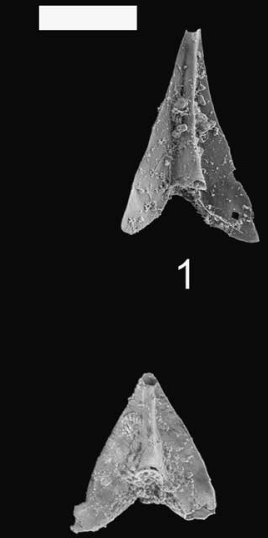

6
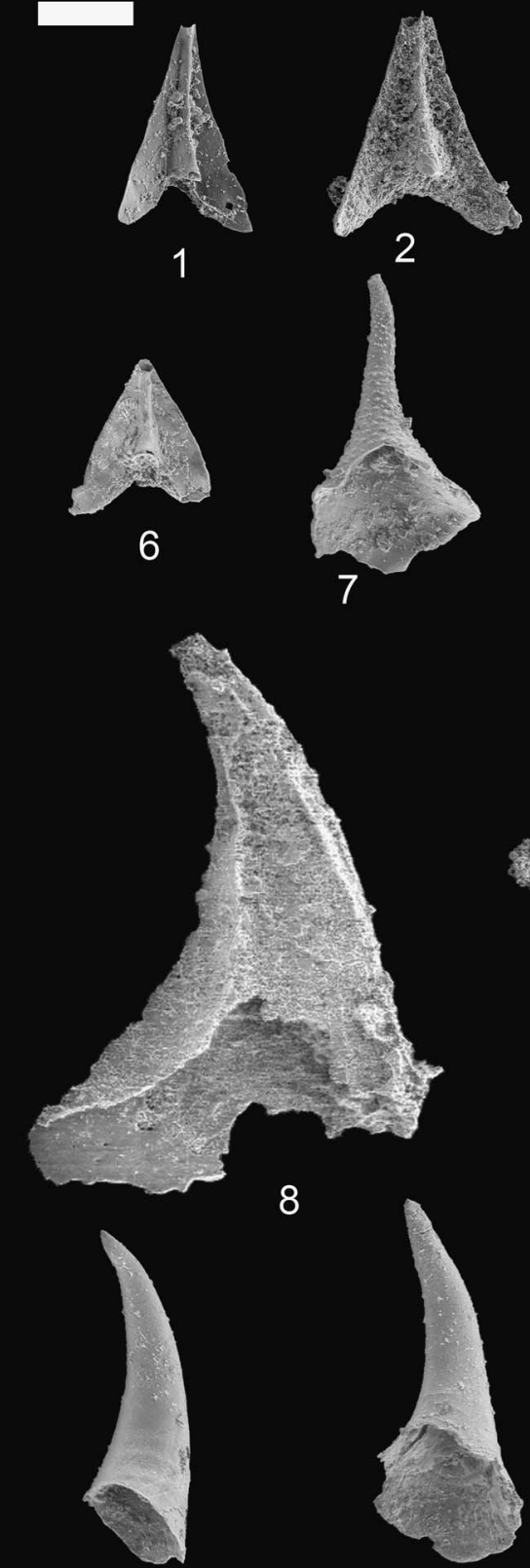

13

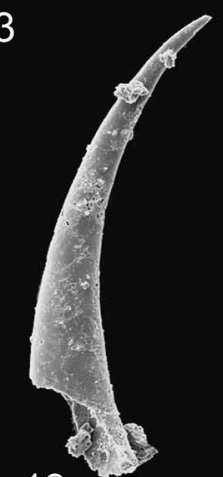

19

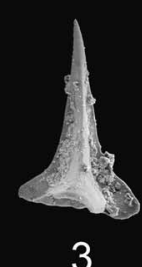

3

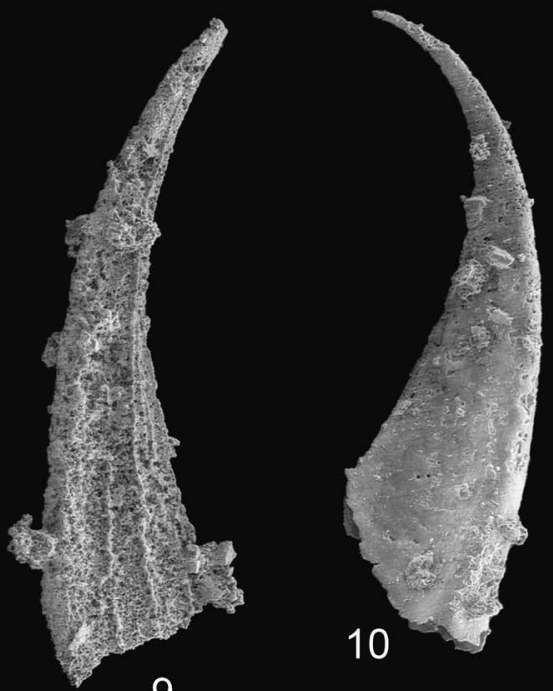

9

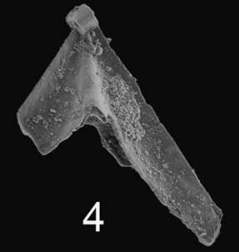

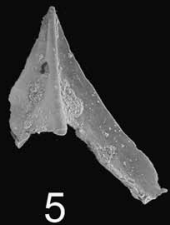
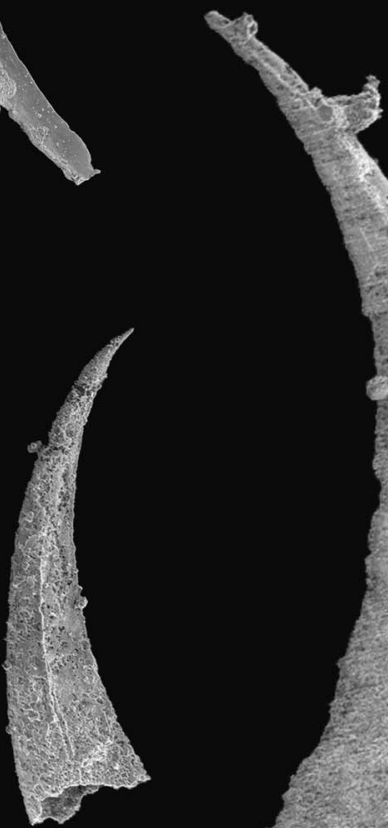

11

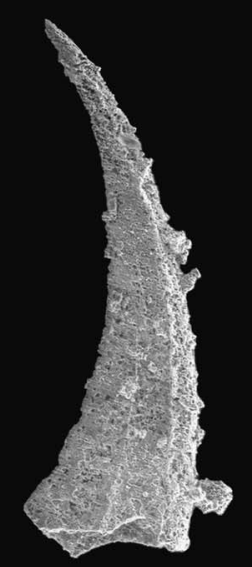

15

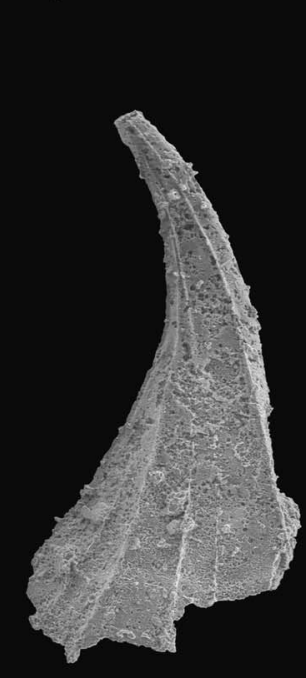

16

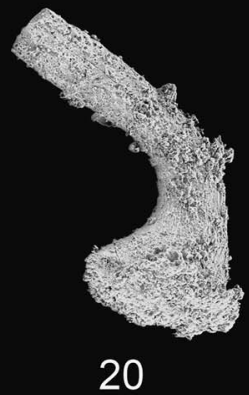

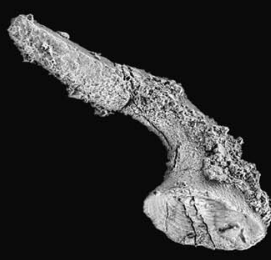

21

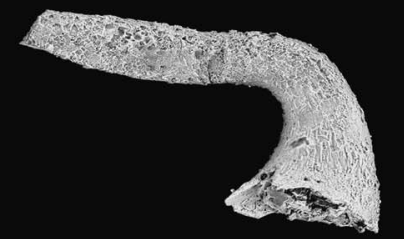

22

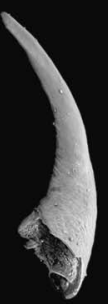

17

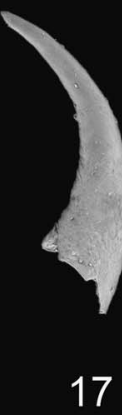

12

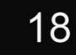



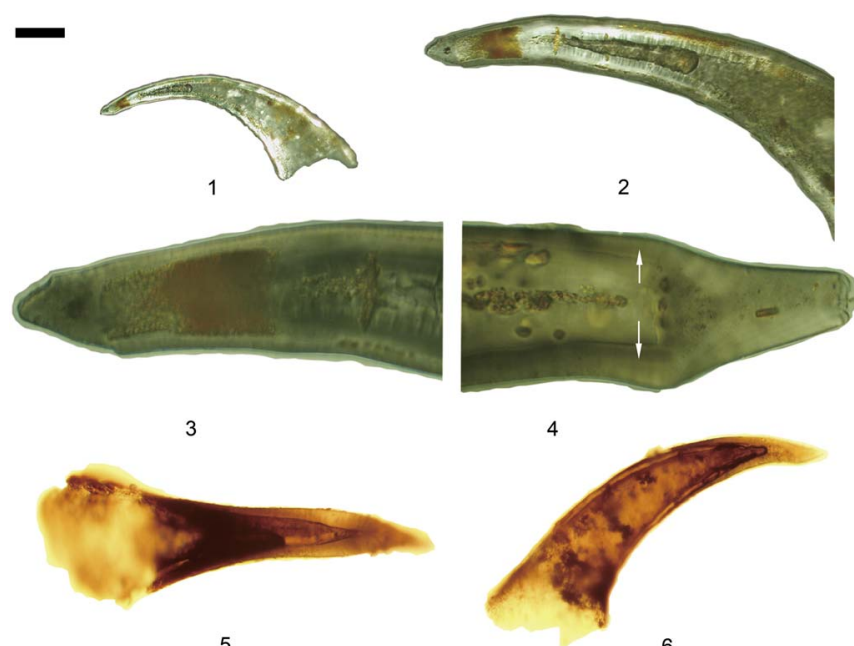

5
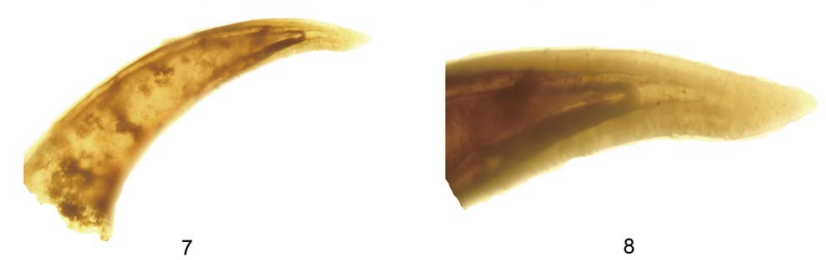

8

Figure 22. Conodont images using oil immersion techniques (Dong et al., 2005c) with Differential Interference Contrast (Nomarski) illumination, showing euconodont structure. (1-8) Millerodontus intermedius $\mathrm{n}$. gen. n. sp.; (1-4) The same specimen as Figure 21.17; (1) overview, showing the crown structure of euconodont; (2) close-up of the cusp of (1); (3) close-up of the tip of (2), showing the regeneration phenomena of euconodont; (4) close-up of of (3), showing the tiny phosphate crystals perpendicular to growth axis (shown by arrow); (5) the same specimen as Figure 21.14 overview, showing the crown structure of euconodont; (6-8) the same specimen as Figure 21.13; (6) overview; (7) close-up of of (6); (8) close-up of the tip of (7), showing the crown structure of euconodont. Relative scale bar represents $55 \mu \mathrm{m}(\mathbf{1}), 19 \mu \mathrm{m}$ (2), $14 \mu \mathrm{m}$ (3), $12 \mu \mathrm{m}$ (4), $71 \mu \mathrm{m}$ (5), $75 \mu \mathrm{m}$ (6), $62 \mu \mathrm{m}$ (7), $24 \mu \mathrm{m}$ (8).

Description.-Moderate to large coniform elements, erect to proclined and symmetrical or nearly so. The cross section is circular at the apical portion and changes to an oval outline toward the base. Basal cavity is very large and deep, the apex extends nearly to the tip of the element; posterior edges are characterized by a sharp keel that extends from apex to a variable distance down the posterior edge of the element and may be one-third of the total length of the element; anterior keel is lacking.

Materials.-Five specimens.
Occurrence.-Known from the Wa'ergang sections, where it ranges from the Proconodontus Zone through the Eoconodontus Zone.

Proconodontus serratus Miller, 1969

Figure 24.3-24.6

1969 Proconodontus muelleri serratus Miller, p. 438, pl. 66, figs. 41-44.

1971 Coelocerodontus burkei Druce and Jones, p. 61, pl. 11, fig. 12 (not figs. 5-11). (part)

1973 Proconodontus muelleri serratus Miller; Lindström, p. 409, pl. 1 , fig. 6.

1973 Proconodontus serratus Miller; Müller, p. 44, pl. 4, figs. 1, 2.

1980 Proconodontus serratus Miller; Miller, p. 31, pl. 1, fig. 13, text-fig. 4D.

1980 Proconodontus serratus Miller; Landing et al., p. 33, fig. 8I-L.

1982 Proconodontus muelleri serratus Miller; Fortey et al., p. 124, fig. 9 (L).

1983 Proconodontus muelleri Miller; An et al., p. 126, pl. 5, fig. 24a, b. (part)

1985 Proconodontus serratus Miller; Wang, p. 233, pl. 6, fig. 26.

1986 Proconodontus serratus Miller; Chen and Gong, p. 162, pl. 33, figs. 1, 6, 10, text-fig. 62 .

1988 Proconodontus serratus Miller; Lee and Lee, pl. 2, figs. 30, 31 .

1991 Proconodontus serratus Miller; Müller and Hinz, p. 56, pl. 42, figs. 17-21, pl. 43, figs. 1-3, 6, 7, text-fig. 22A.

2000 Proconodontus serratus Miller; Dubinina, p. 195, pl. 6, figs. 21, 21a.

2006 Proconodontus serratus Miller; Miller et al., p. 394, fig. 9 (Q, R).

2007 Proconodontus serratus Miller; Landing et al., p. 918, fig. $6(\mathrm{t})$.

2011 Proconodontus serratus Miller; Miller et al., p. 604, fig. 7C, D.

Description.-Moderate to large coniform elements, proclined and symmetrical. The cross section is laterally compressed. Basal cavity is very large and deep, with the apex extending nearly to the tip of the element. Anterior and posterior edges are characterized by prominent keels. The posterior keel is serrated except for the apical portion.

Materials.-Six specimens.

Figure 21. (1, 2) Laiwugnathus hunanensis n. sp.; (1) Huaqiao Formation, Wangcun section, holotype, GMPKU2722, posterior view; (2) Huaqiao Formation, Wangcun section, GMPKU2723, posterior view; (3) Laiwugnathus cf. kouzhenensis An, 1982, Chefu Formation, Wangcun section, GMPKU2724, posterior view; (4-6) Laiwugnathus transitans n. sp.; (4) Chefu Formation, Wangcun section, GMPKU2725, posterior view; (5) Chefu Formation, Wangcun section, holotype, GMPKU2726, posterior view; (6) Bitiao Formation, Wangcun section, GMPKU2727, lateral view; (7) Mamillodus ruminatus Dubinina, 2000, Shenjiawan Formation, Wa'ergang section, GMPKU2728, posterior view; (8-12, 15, 16) Miaognathus multicostatus n. gen. n. sp.; (8) Shenjiawan Formation, Wa'ergang section, GMPKU2729, lateral view; (9) Shenjiawan Formation, Wa'ergang section, GMPKU2730, lateral view; (10) Shenjiawan Formation, Wa'ergang section, GMPKU2731, lateral view; (11) Shenjiawan Formation, Wa'ergang section, GMPKU2732, lateral view; (12) Shenjiawan Formation, Wa'ergang section, holotype, GMPKU2733, lateral view; (15) Shenjiawan Formation, Wa'ergang section, GMPKU2734, lateral view; (16) Shenjiawan Formation, Wa'ergang section, GMPKU2735, lateral view; (13, 14, 17-19) Millerodontus intermedius n. gen. n. sp.; (13) Shenjiawan Formation, Wa'ergang section, GMPKU2736, lateral view; (14) Shenjiawan Formation, Wa'ergang section, GMPKU2737, lateral view; (17) Shenjiawan Formation, Wa'ergang section, holotype, GMPKU2252, lateral view; (18) the same specimen, posterior-lateral view; (19) Shenjiawan Formation, Wa'ergang section, GMPKU2167, lateral view; (20-23) Monocostodus sevierensis Miller, 1980; (20) Panjiazui Formation, Wa'ergang section, GMPKU2738, lateral view; (21) Panjiazui Formation, Wa'ergang section, GMPKU2739, lateral view; (22) Panjiazui Formation, Wa'ergang section, GMPKU2740, lateral view; (23) Panjiazui Formation, Wa'ergang section, GMPKU2741, lateral view; Relative scale bar represents 146 $\mu$ m $(\mathbf{1}, \mathbf{1 7}, \mathbf{2 3}), 156 \mu \mathrm{m}(\mathbf{2 - 1 6 , 1 8 , 2 0 - 2 2 )}, 103 \mu \mathrm{m}(\mathbf{1 9})$. 

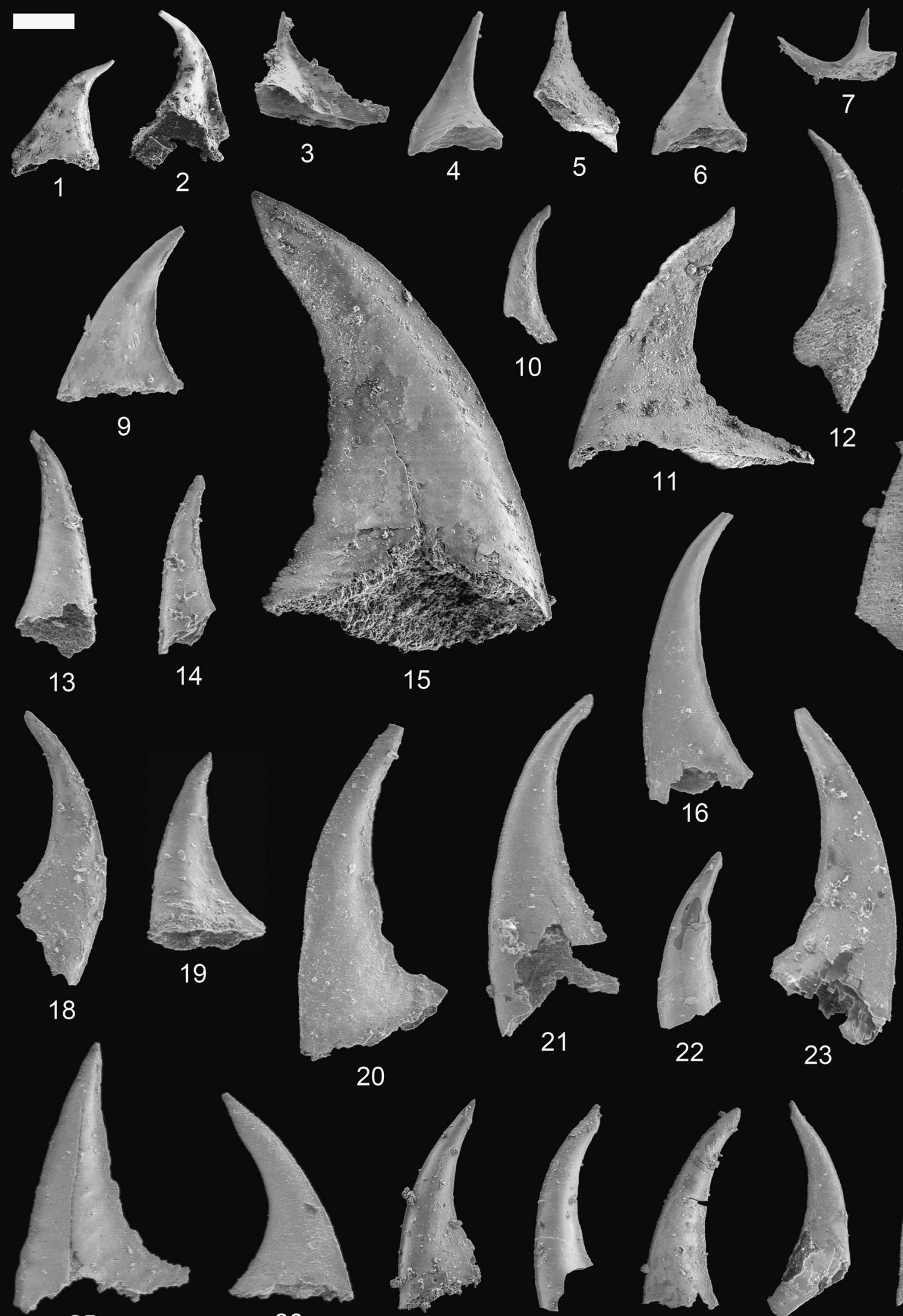

25
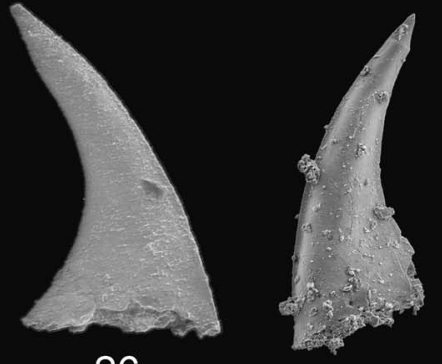

27

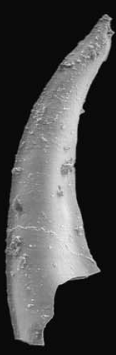

28
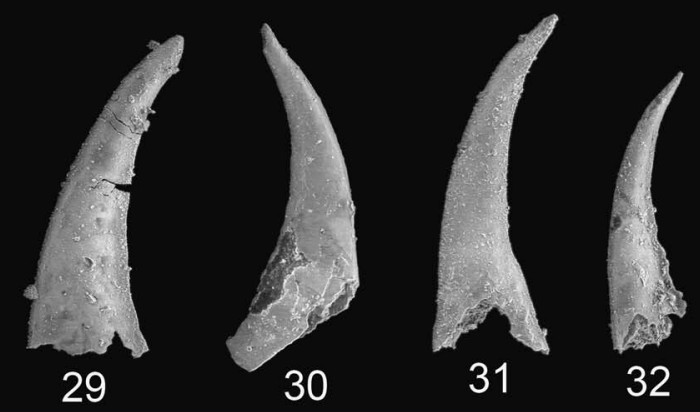
Occurrence.-Known from the Wa'ergang sections, where it ranges from the Proconodontus Zone through the Eoconodontus Zone.

\section{Proconodontus tenuiserratus Miller, 1980}

Figure 24.7, 24.8, 24.11

1971 Coelcerodontus burkei Druce and Jones, p. 61, text-fig. 22e, pl. 11, figs. 5, 6 (not figs. 7-12). (part)

1980 Proconodontus tenuiserratus Miller, p. 31, textfig. 4A, pl. 1, figs. 1-3.

1982 Proconodontus tenuiserratus Miller; An, p. 143, pl. 12, figs. 1, 2, 5 .

1985 Proconodontus tenuiserratus Miller; Wang, p. 233, pl. 8, fig. 7, ?pl. 12, fig. 8 .

1986 Proconodontus tenuiserratus Miller; Chen and Gong, pl. 29, figs. 1-16, pl. 30, figs. 2, 5-7, text-fig. 63.

2000 Proconodontus tenuiserratus Miller; Dubinina, p. 195, pl. 6, fig. 22.

2002a Proconodontus tenuiserratus Miller; Lee, p. 165, pl. 2, fig. 24.

2002b Proconodontus tenuiserratus Miller; Lee, p. 27, pl. 2, figs. 10, 11.

2004 Proconodontus tenuiserratus Miller; Lee, p. 60, fig. 5 (Y).

2004c Proconodontus tenuiserratus Miller; Dong et al., pl. 1, figs. 7, 12, pl. 2, fig. 26.

Description.-Moderate to small coniform elements, erect to proclined and symmetrical. The cross section is usually circular, rarely compressed laterally near the base. Basal cavity is very deep, with the apex extending nearly to the tip of the element. The posterior side is characterized by a keel that is small, finely serrated, and extends from tip about halfway to the base, but it extends from the tip nearly to the base in some advanced forms. Anterior keel is lacking.

Materials.—12 specimens.

Occurrence.-Known from the Wa'ergang section, where it ranges from the Proconodontus tenuiserratus Zone through the Proconodontus Zone.

Genus Teridontus Miller, 1980
Type species.—Oneotodus nakamurai Nogami, 1967.

Teridontus nakamurai (Nogami, 1967)

Figure 25.4, 25.5, 25.8-25.15, 25.17-25.22

1959 Oneotodus sp. A Müller, p. 458, pl. 13, fig. 17.

1967 Oneotodus nakamurai Nogami, p. 216, text-figs. 3A, B, C, ?D, ?E, pl. 1, figs. 9-13.

1969 Oneotodus nakamurai Nogami; Miller, p. 435, textfig. 5E, pl. 63, figs. 1-10.

1971 Oneotodus nakamurai Nogami; Druce and Jones, p. 82, text-fig. 26i, pl. 10, figs. 3, 4, 7, 8. (part)

1973 Oneotodus nakamurai Nogami; Müller, p. 41, pl. 5, fig. 4.

1971 Oneotodus datsonensis Druce and Jones, p. 80, textfig. 26c, pl. 14, figs. 1-3. (part)

1980 Teridontus nakamurai (Nogami); Miller, p. 34, pl. 2, figs. 15,16 , text-fig. $4(\mathrm{O})$.

1982 Teridontus nakamurai (Nogami); An, p. 150, pl. 14, figs. 1-11, pl. 15, fig. 11 .

1983 Teridontus nakamurai (Nogami); An et al., p. 156, pl. 6, figs. 1-6.

1985 Teridontus nakamurai (Nogami); Wang, p. 241, pl. 3, figs. 1, 2, 4, pl. 6, figs. 9-12, pl. 8, figs. 1-3, pl. 10, figs. 1-3, pl. 13, figs. 5, 11, 12 .

1985 Teridontus nakamurai (Nogami); Dong, p. 405, pl. 1, figs. 5, 18, text-fig. $1(\mathrm{H})$.

1986 Teridontus nakamurai (Nogami); Chen and Gong, p. 192, pl. 34, fig. 12, pl. 39, figs. 1, 3, 9, 11-13, pl. 40 , figs. $1,3,5,7,9,12-13$, pl. 47 , figs. 7,8 , pl. 48 , fig. 16, text-fig. $79(1-12,15,16)$.

1987 Teridontus nakamurai (Nogami); Dong, p. 175, pl. 1, figs. 27-28.

1996 Teridontus nakamurai (Nogami); Lee et al., p. 97, pl. 1, figs. $2,8$.

1999 Teridontus nakamurai (Nogami); Parsons and Clark, p. 7, fig. $5(17-18, ? 23)$.

2000 Teridontus nakamurai (Nogami); Dubinina, p. 196, pl. 6, figs. 2, 4, 5, 7, 8, 8a.

2000 Teridontus nakamurai (Nogami); Zhao et al., p. 227, pl. 9, figs. 19-26.

2001 Teridontus nakamurai (Nogami); Lee, p. 450, fig. 7 $(1,2,4-8,10-13)$.

Figure 23. (1-6) Proacodus pulcherus (An, 1982); (1) Bitiao Formation, Wangcun section, GMPKU2793, anterior view; (2) Bitiao Formation, Wangcun section, GMPKU2794, posterior view; (3) Bitiao Formation, Wangcun section, GMPKU2795, posterior view; (4) Shenjiawan Formation, Wa'ergang section, GMPKU2796, posterior view; (5) Bitiao Formation, Wangcun section, GMPKU2797, posterior view; (6) Shenjiawan Formation, Wa'ergang section, GMPKU2798, posterior view; (7) Proacodus cf. pulcherus (An, 1982) Bitiao Formation, Wangcun section, GMPKU2799, posterior view; (8-32) Proconodontus muelleri Miller, 1969; (8) Shenjiawan Formation, Wangcun section, GMPKU2800, lateral view; (9) Shenjiawan Formation, Wa'ergang section, GMPKU2801, lateral view; (10) Shenjiawan Formation, Wa'ergang section, GMPKU2802, lateral view; (11) Shenjiawan Formation, Wangcun section, GMPKU2803, lateral view; (12) Shenjiawan Formation, Wa'ergang section, GMPKU2804, lateral view; (13) Shenjiawan Formation, Wa'ergang section, GMPKU2805, lateral view; (14) Shenjiawan Formation, Wa'ergang section, GMPKU2806, lateral view; (15) Shenjiawan Formation, Wangcun section, GMPKU2807, lateral view; (16) Shenjiawan Formation, Wa'ergang section, GMPKU2808, lateral view; (17) Shenjiawan Formation, Wa'ergang section, GMPKU2809, lateral view; (18) Shenjiawan Formation, Wa'ergang section, GMPKU2810, lateral view; (19) Shenjiawan Formation, Wa'ergang section, GMPKU2811, lateral view; (20) Shenjiawan Formation, Wa'ergang section, GMPKU2812, lateral view; (21) Shenjiawan Formation, Wa'ergang section, GMPKU2813, lateral view; (22) Shenjiawan Formation, Wa'ergang section, GMPKU2814, lateral view; (23) Shenjiawan Formation, Wa'ergang section, GMPKU2815, lateral view; (24) Shenjiawan Formation, Wa'ergang section, GMPKU2816, lateral view; (25) Shenjiawan Formation, Wa'ergang section, GMPKU2817, lateral view; (26) Shenjiawan Formation, Wa'ergang section, GMPKU2818, lateral view; (27) Shenjiawan Formation, Wa'ergang section, GMPKU2819, lateral view; (28) Shenjiawan Formation, Wa'ergang section, GMPKU2820, lateral view; (29) Shenjiawan Formation, Wa'ergang section, GMPKU2821, lateral view; (30) Shenjiawan Formation, Wa'ergang section, GMPKU2822, lateral view; (31) Shenjiawan Formation, Wa'ergang section; GMPKU2823, lateral view; (32) Shenjiawan Formation, Wa'ergang section, GMPKU2824, lateral view. Relative scale bar represents $165 \mu \mathrm{m}(\mathbf{1 - 6}, \mathbf{8 - 2 1}, \mathbf{2 3}, \mathbf{2 4}, \mathbf{2 8}), 156 \mu \mathrm{m}(\mathbf{7}, \mathbf{2 7})$, $173 \mu \mathrm{m}(\mathbf{2 2}, \mathbf{2 5}, \mathbf{2 6}, \mathbf{2 9 - 3 2})$. 


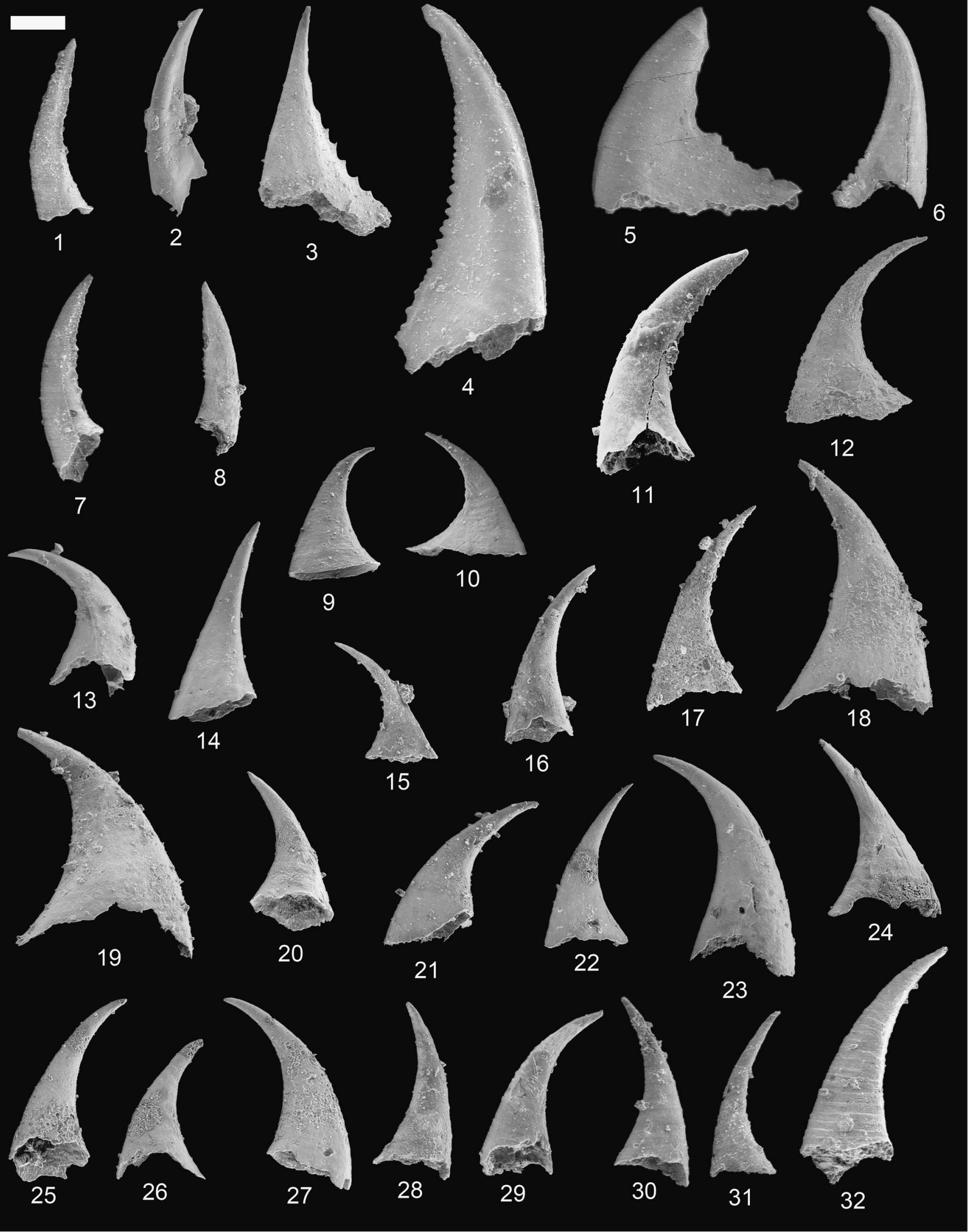


2002 Teridontus nakamurai (Nogami); Lee, p. 165, pl. 2, fig. 15.

2002 Teridontus nakamurai (Nogami); Lee, p. 27, pl. 2, fig. 21.

2003 Teridontus nakamurai (Nogami); Landing et al., p. 86, fig. 7 (3).

2005 Teridontus nakamurai (Nogami); Ortega and Albanesi, p. 365 , figs. $17-18$.

2007 Teridontus nakamurai (Nogami); Landing et al., p. 918, fig. 6 (i-1).

2007 Teridontus nakamurai (Nogami); Pyle et al., p. 1733, fig. $10(6,7)$.

2009 Teridontus nakamurai (Nogami); Lee et al., p. 423, fig. 7 (2).

Description.-Simple coniform elements with much morphological variation. Base is usually long but is short in advanced forms. Cusp is erect to reclined and is almost entirely composed of white matter that terminates in sharp boundary that is transverse to the cusp at a point slightly above the tip of basal cavity. Cross section is circular to oval. Fine lengthwise striae are usually preserved on the surface of the whole element.

Materials.—100 specimens.

Occurrence.-Known from the Wangcun and Wa'ergang sections, where it ranges from the Proconodontus Zone through the Cordylodus angulatus Zone.

\section{Genus Tujiagnathus new genus}

Type species.-Tujiagnathus gracilis $\mathrm{n}$. gen. $\mathrm{n}$. sp.

Diagnosis.-Slender, cylindrical coniform elements with a minute hook-like cusps. The posterior side is ornamented by numerous tiny nodes. Basal cavity is very deep.

Etymology.-Tujia, ethnic minority group in western Hunan, South China; gnathus, Greek, jaw.

\section{Tujiagnathus gracilis new genus new species}

Figure 25.16, 25.23

Diagnosis._As for the genus.
Description.-Coniform elements, moderate to small, and symmetrical. The cusp is small and hook-like. The base is slender and cylindrical. Both anterior and posterior sides are rounded. The posterior side is ornamented by numerous tiny nodes. Basal cavity is very deep, with the apex extending above the point of flexure of the element.

Etymology.—gracilis, Latin, gracile or slender.

Types.-Holotype: GMPKU2934 from the Westergaardodina cf. calix-Prooneotodus rotundatus Zone, Bitiao Formation, Wangcun section, Wangcun village, Yongshun county, Hunan Province.

Materials.—Nine specimens.

Occurrence.-Known from Wangcun section, where it occurs in the Westergaardodina cf. calix-Prooneotodus rotundatus Zone.

Comparison.-In gross morphology, the present species looks like Prooneotodus terashimai, but Tujiagnathus gracilis has conspicuous surface ornamentation, so it is a euconodont (Bengtson, 1976), whereas P. terashimai is a paraconodont.

Genus Wangcunella new genus

Type species.—Wangcunella conicus $\mathrm{n}$. gen. n. sp.

Diagnosis.-Coniform elements without differentiation between cusp and base. Basal cavity is shallow. Cross section is circular.

Etymology.-Named for the Wangcun section in Hunan Province.

Wangcunella conicus new genus new species Figure 25.24-25.28

Diagnosis.—As for the genus.

Description.-Elements with conical gross morphology. There is no differentiation between cusp and base. The large base tapers rapidly toward the tip. Basal cavity is shallow. Cross section is circular from the apex through the base.

Figure 24. (1, 2) Proconodontus posterocostatus Miller, 1980; (1) Shenjiawan Formation, Wa'ergang section, GMPKU2825, lateral view; (2) Shenjiawan Formation, Wa'ergang section, GMPKU2826, lateral view; (3-6) Proconodontus serratus Miller, 1969; (3) Shenjiawan Formation, Wa'ergang section, GMPKU2827, lateral view; (4) Shenjiawan Formation, Wa'ergang section, GMPKU2828, lateral view; (5) Shenjiawan Formation, Wa'ergang section, GMPKU2829, lateral view; (6) Shenjiawan Formation, Wa'ergang section, GMPKU2830, lateral view; (7, 8, 11) Proconodontus tenuiserratus Miller, 1980; (7) Shenjiawan Formation, Wa'ergang section, GMPKU2831, lateral view; (8) Shenjiawan Formation, Wa'ergang section, GMPKU2832, lateral view; (11) Shengjiawan Formation, Wangcun section, GMPKU2168, lateral view; (9, 10, 12-32) Prooneotodus gallatini Müller, 1959; (9) Bitiao Formation, Wangcun section, GMPKU2833, lateral view; (10) Bitiao Formation, Wangcun section, GMPKU2834, lateral view; (12) Bitiao Formation, Wangcun section, GMPKU2835, lateral view; (13) Bitiao Formation, Wangcun section, GMPKU2836, lateral view; (14) Bitiao Formation, Wangcun section, GMPKU2837, lateral view; (15) Bitiao Formation, Wangcun section, GMPKU2838, lateral view; (16) Bitiao Formation, Wangcun section, GMPKU2839, lateral view; (17) Bitiao Formation, Wangcun section, GMPKU2840, lateral view; (18) Bitiao Formation, Wangcun section, GMPKU2841, lateral view; (19) Bitiao Formation, Wangcun section, GMPKU2842, lateral view; (20) Bitiao Formation, Wangcun section, GMPKU2843, lateral view; (21) Bitiao Formation, Wangcun section, GMPKU2844, lateral view; (22) Bitiao Formation, Wangcun section, GMPKU2845, lateral view; (23) Bitiao Formation, Wangcun section, GMPKU2846, lateral view; (24) Bitiao Formation, Wangcun section, GMPKU2847, lateral view; (25) Bitiao Formation, Wangcun section, GMPKU2848, lateral view; (26) Bitiao Formation, Wangcun section, GMPKU2849, lateral view; (27) Bitiao Formation, Wangcun section, GMPKU2850, lateral view; (28) Bitiao Formation, Wangcun section, GMPKU2851, lateral view; (29) Bitiao Formation, Wangcun section, GMPKU2852, lateral view; (30) Bitiao Formation, Wa'ergang section, GMPKU2853, lateral view; (31) Bitiao Formation, Wa'ergang section, GMPKU2854, lateral view; (32) Shenjiawan Formation, Wa'ergang section, GMPKU2855, lateral view. Scale bar represents $138 \mu \mathrm{m}(\mathbf{1 - 3 2})$. 


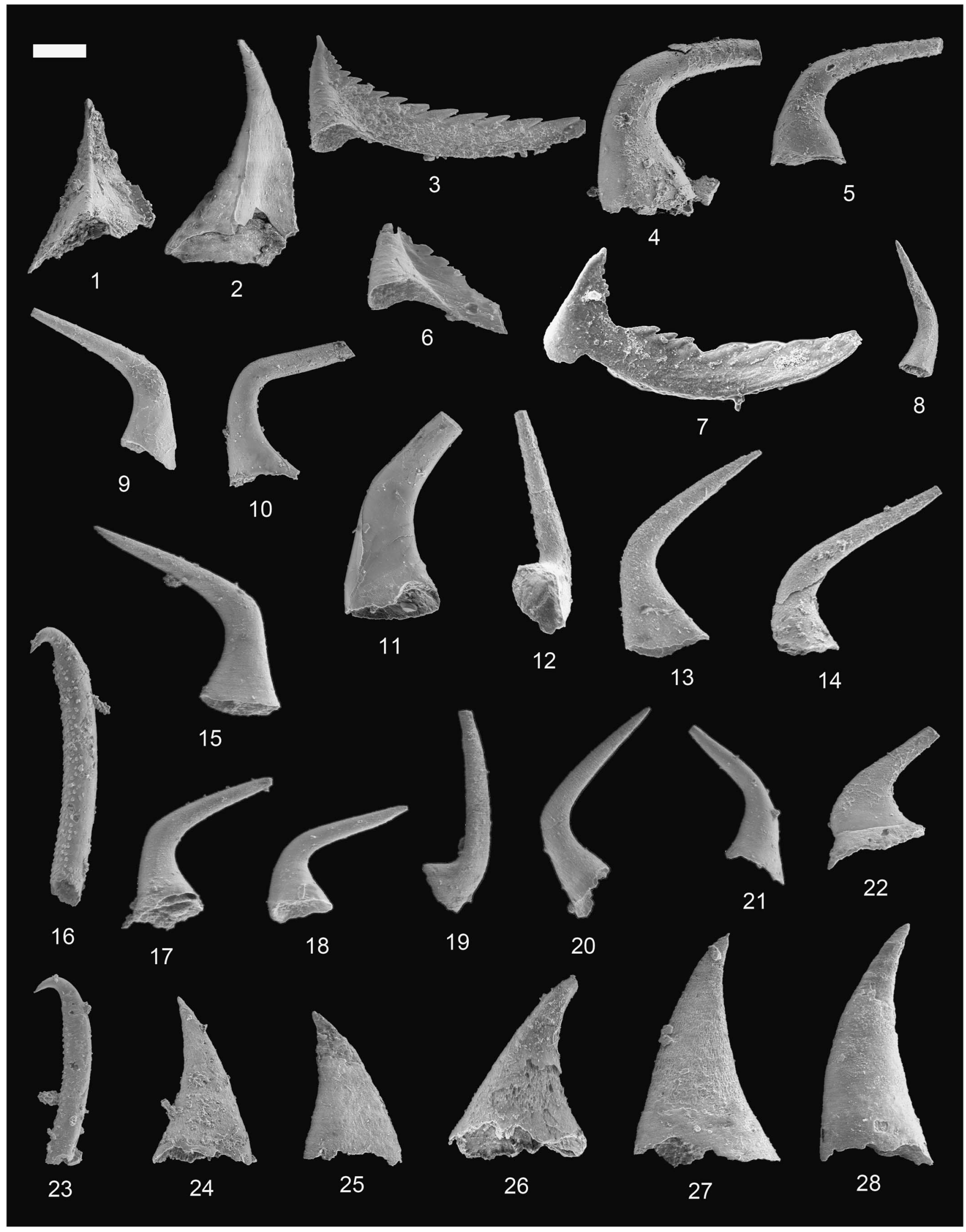


Etymology.-conicus, Latin, conical, referring to the gross morphology of the element.

Types.-Holotype: GMPKU2936, from the Westergaardodina cf. calix-Prooneotodus rotundatus Zone, Bitiao Formation, Wangcun section, Wangcun village, Yongshun county, Hunan Province.

Materials._-18 specimens.

Occurrence.-Known from the Wangcun and Wa'ergang sections, where it ranges from the Westergaardodina lui-Westergaardodina ani Zone through the Eoconodontus Zone.

\section{Paraconodonts}

Class Paraconodontida Müller, 1962

[nomen translatum (pro Order Paraconodontida Müller, 1962), emended Landing, 1995]

Genus Furnishina Müller, 1959

Type species._Furnishina furnishi Müller, 1959.

Furnishina cf. alata Szaniawski, 1971

Figure 26.29, 26.30

cf. 1971 Furnishina alata Szaniawski, p. 406, pl. 1, figs. 3, 4, pl. 3, figs. 3-5.

1987 Furnishina aff. furnishi Müller; An, pl. 3, fig. 8.

1991 Furnishina cf. alata Szaniawski; Müller and Hinz, p. 16, pl. 7, figs. 18, 20.

1993 Furnishina cf. alata Szaniawski; Dong, p. 350, pl. 2, figs. 11, 13, 15.

2001a Furnishina cf. alata Szaniawski; Dong and Bergström, p. 960, pl. 1, figs. 1, 3, 10.

2006 Furnishina cf. F. alata Szaniawski; Qi et al., p. 182, pl. 2, fig. 15.

2008 Furnishina cf. alata Szaniawski; Bagnoli et al., p. 112, fig. 3 (A).

Materials.—48 specimens.

Occurrence.-Present in the Paibi and Wangcun sections from the Shandongodus priscus-Hunanognathus tricuspidatus Zone through the Westergaardodina matsushita-Westergaardodina grandidens Zone.
Remarks.-The specimens at hand agree in gross morphology with Furnishina alata but differ in the posterior keel, which is not developed or present only along the cusp.

\section{Furnishina bigeminata Dong, 1993}

Figure 17.20-17.25

1993 Furnishina bigeminata Dong, p. 350, pl. 4, figs. 3, 4, 6, 14.

2001a Furnishina bigeminata Dong; Dong and Bergström, p. 960, pl. 3, fig. 17, pl. 5, fig. 14.

2006 Furnishina bigeminata Dong; Qi et al., p. 186, pl. 2, fig. 6.

2008 Furnishina bigeminata Dong; Bagnoli et al., p. 112, fig. 3 (B).

Materials._688 specimens.

Occurrence.-Present in the Paibi, Wangcun, and Wa'ergang sections, where it ranges from the Gapparodus bisulcatusWestergaardodina brevidens Zone through the Cordylodus proavus Zone.

Remarks.-The present specimens agree well with Furnishina bigeminata as described and figured by Dong and Bergström (2001a).

Furnishina dayangchaensis Chen and Gong, 1986 Figure 17.26-17.31

1986 Furnishina dayangchaensis Chen and Gong, p. 144, pl. 17, figs. 2, 3, 6, 8, 9, 14, pl. 19, fig. 11, text-fig. 50 (2).

2000 Furnishina furnishi Müller; Dubinina, p. 168, pl. 2, fig. 17. (part)

Materials._-78 specimens.

Occurrence.-Present in the Wangcun and Wa'ergang sections, where it ranges from the Westergaardodina lui-Westergaardodina ani Zone through the Cordylodus proavus Zone.

Remarks.-The present specimens agree well with Furnishina dayangchaensis as described and figured by Chen and Gong (1986).

Furnishina furnishi Müller, 1959

Figure 27.1-27.9

\footnotetext{
Figure 25. (1, 2) Prosagittodontus cf. eureka (Müller, 1959); (1) Bitiao Formation, Wangcun section, GMPKU2913, posterior view; (2) Shenjiawan Formation, Wa'ergang section, GMPKU2914, posterior view; (3, 6, 7) Serratocambria minuta Müller and Hinz, 1991; (3) Bitiao Formation, Wangcun section, GMPKU2915, posterior view; (6) Bitiao Formation, Wangcun section, broken specimen, GMPKU2916, posterior view; (7) Bitiao Formation, Wangcun section, GMPKU2917, anterior view; (4, 5, 8-15, 17-22) Teridontus nakamurai (Nogami, 1967); (4) Shenjiawan Formation, Wangcun section, GMPKU2918, lateral view; (5) Shenjiawan Formation, Wangcun section, GMPKU2919, lateral view; (8) Shenjiawan Formation, Wangcun section, GMPKU2920, lateral view; (9) Shenjiawan Formation, Wangcun section, GMPKU2921, lateral view; (10) Shenjiawan Formation, Wangcun section, GMPKU2922, lateral view; (11) Shenjiawan Formation, Wangcun section, GMPKU2923, lateral view; (12) Shenjiawan Formation, Wa'ergang section, GMPKU2924, lateral view; (13) Shenjiawan Formation, Wa'ergang section, GMPKU2925, lateral view; (14) Shenjiawan Formation, Wa'ergang section, GMPKU2926, lateral view; (15) Shenjiawan Formation, Wa'ergang section, GMPKU2927, lateral view; (17) Shenjiawan Formation, Wa'ergang section, GMPKU2928, lateral view; (18) Shenjiawan Formation, Wa'ergang section, GMPKU2929, lateral view; (19) Shenjiawan Formation, Wa'ergang section, GMPKU2930, lateral view; (20) Shenjiawan Formation, Wa'ergang section, GMPKU2931, lateral view; (21) Shenjiawan Formation, Wa'ergang section, GMPKU2932, lateral view; (22) Shenjiawan Formation, Wa'ergang section, GMPKU2933, lateral view; (16, 23) Tujiagnathus gracilis n. gen. n. sp.; (16) Bitiao Formation, Wangcun section, GMPKU2934, holotype, lateral view; (23) Bitiao Formation, Wangcun section, GMPKU2935, lateral view; (24-28) Wangcunella conicus n. gen. n. sp.; (24) Bitiao Formation, Wangcun section, GMPKU2936, lateral view; (25) Bitiao Formation, Wangcun section, GMPKU2937, lateral view; (26) Bitiao Formation, Wangcun section, GMPKU2938, lateral view; (27) Bitiao Formation, Wa'ergang section, GMPKU2939, lateral view; (28) Bitiao Formation, Wa'ergang section, GMPKU2940, holotype, lateral view. Scale bar represents $130 \mu \mathrm{m}(\mathbf{1 - 2 8})$.
} 


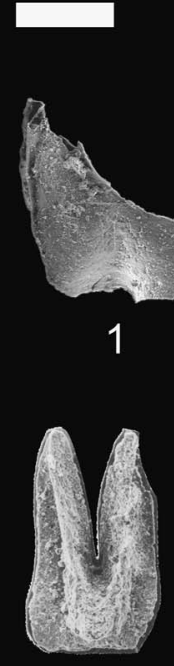

8

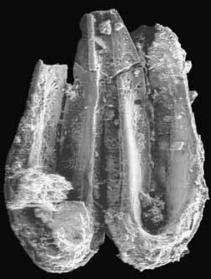

14

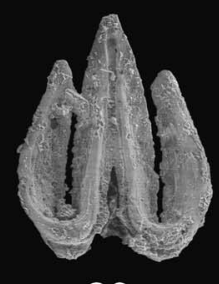

20
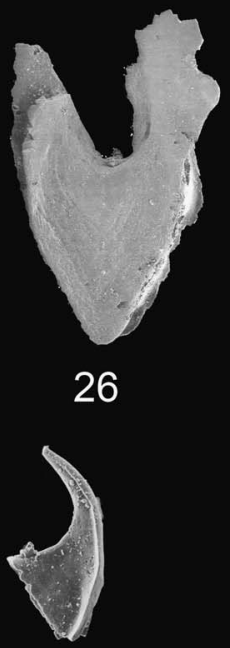

32
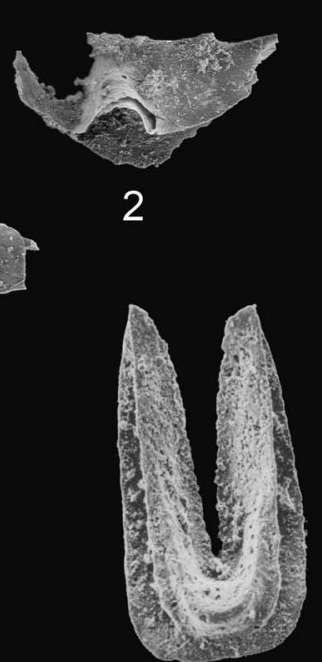

9

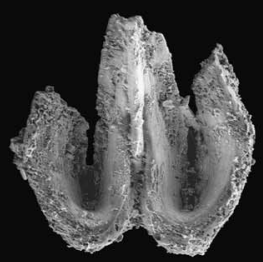

15
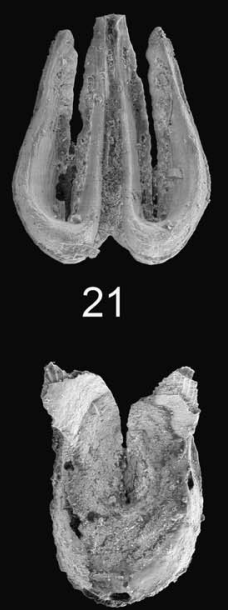

27

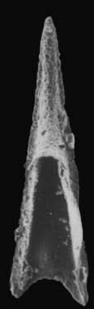

33

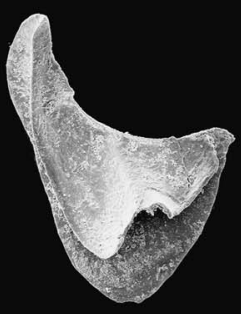

3

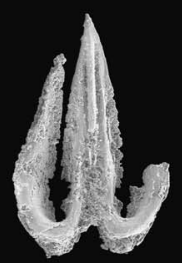

10

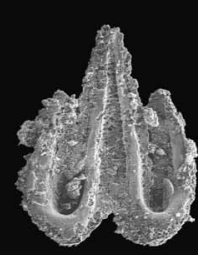

16
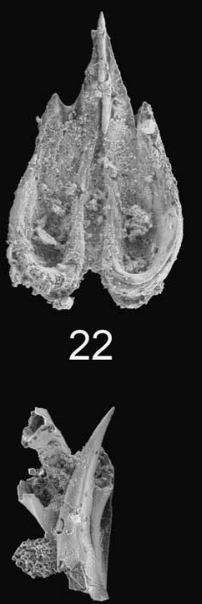

28

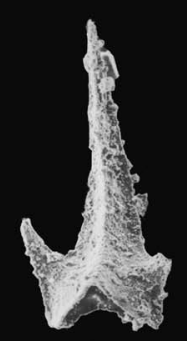

34
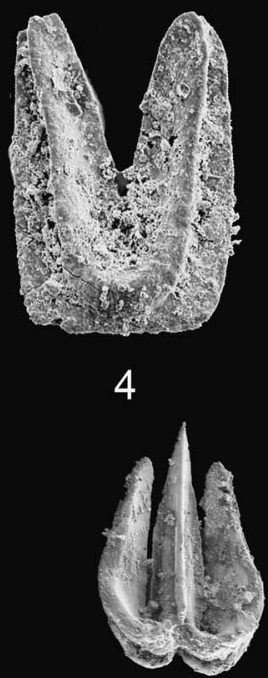

11
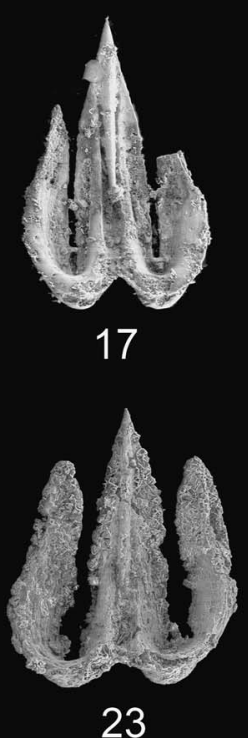

23

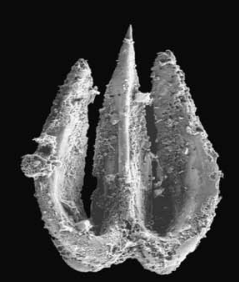

12

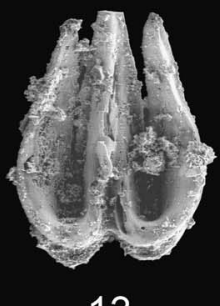

13

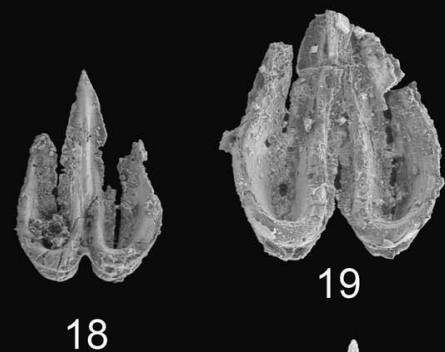

18
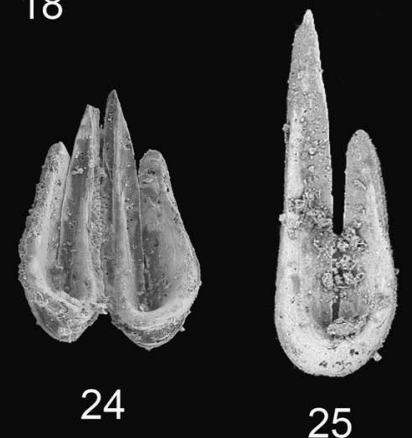
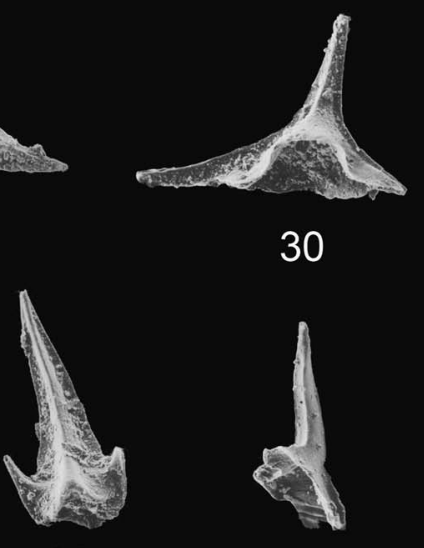

36
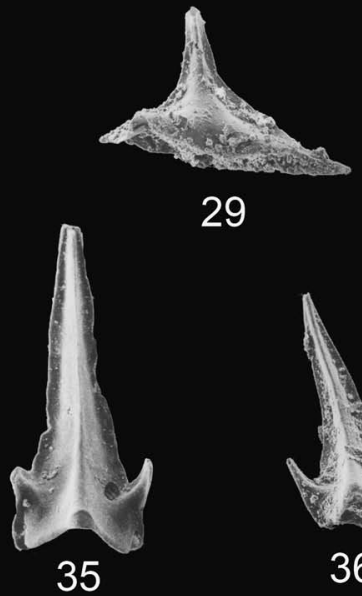

30
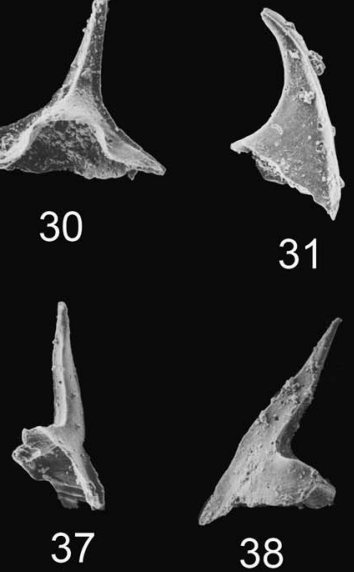
1959 Furnishina furnishi Müller, p. 452, pl. 11, figs. 5, 6, 9, 11-13, 15, text-fig. 6D.

1971 Furnishina asymmetrica Müller; Müller, p. 8, pl. 1, figs. 9, 12, 14-16.

1971 Furnishina furnishi Müller; Müller and Nogami, p. 14, pl. 1, fig. 5 .

1972 Furnishina furnishi Müller; Müller and Nogami, fig. $1 \mathrm{~A}$.

1973 Furnishina asymmetrica Müller; Müller, p. 39, pl. 1, figs. 6, 8.

? 1976 Furnishina furnishi Müller; Abaimova and Ergaliev, p. 391, pl. 14, figs. 1, 2.

? 1976 Furnishina furnishi Müller; Miller et al., p. 595, pl. 1, figs. 8-12.

1979 Furnishina furnishi Müller; Bednarczyk, p. 427, pl. 1, figs. 1-3, 5-9, 12, pl. 3, figs. 14, 20, 21.

1981 Furnishina furnishi Müller; Miller in Robison, p. W112, fig. 64, 7a, b.

1986 Furnishina furnishi Müller; Chen et al., p. 367, pl. 1, fig. 17.

1988 Furnishina furnishi Müller; Lee and Lee, pl. 1, figs. 16, 17.

1991 Furnishina furnishi Müller; Müller and Hinz, p. 17, pl. 13, figs. 1-7, 11, 12, text-fig. 8 (A).

? 2000 Furnishina furnishi Müller; Göncüoğlu and Kozur, p. 599, fig. 4 (h).

? 2000 Furnishina furnishi Müller; Dubinina, p. 168, pl. 3, figs. 9-10 (not pl. 1, figs. 8, 9, 26, pl. 3, figs. 2, 3, 12, 23, 25). (part)

2009 Furnishina furnishi Müller; Lee et al., p. 421, fig. 6 (17).

Materials.—30 specimens.

Occurrence.-Known from the Wangcun and Wa'ergang sections, where it ranges from the Westergaardodina luiWestergaardodina ani Zone through the Cordylodus proavus Zone.

Remarks.-Müller and Hinz (1991) emended the diagnosis of Furnishina furnishi. Previously, it was defined very broadly and included a variety of forms that could not be assigned properly to another species. The new diagnosis restricted the occurrence of $F$. furnishi, so that it ranges from the trilobite zone 3 through zone 5 in the upper Cambrian of Sweden. Accordingly, many elements previously refered to $F$. furnishi by different authors, especially Chinese authors, should be excluded from this species based on their characters and occurrences.

Furnishina cf. furnishi Müller, 1959

Figure 27.10-27.16

cf. 1959 Furnishina furnishi Müller, p. 452, pl. 11, figs. 5, 6, 9, 11-13, 15, text-fig. 6D.

cf. 1991 Furnishina furnishi Müller; Müller and Hinz, p. 17, pl. 13, figs. 1-7, 11, 12; text-fig. 8 (A).

2000 Furnishina furnishi Müller; Dubinina, p. 168, pl. 3, fig. 11. (part)

2007 Furnishina furnishi Müller; Landing et al., p. 922, fig. 9 (c).

2009 Furnishina furnishi Müller; Lee et al., p. 423, fig. 7 (16), p. 425 , fig. 8 (10).

Materials.—16 specimens.

Occurrence.-Known from the Wangcun and Wa'ergang sections, where it ranges from the Westergaardodina luiWestergaardodina ani Zone through the Eoconodontus Zone.

Remarks.-Similar to Furnishina furnishi but differs in the posterior side, which is not convexly domed, and the median keel is indistinct.

Furnishina gladiata Müller and Hinz, 1991

Figure 27.17

1959 Scandodus n. sp. b Müller, p. 464, pl. 12, fig. 5.

1991 Furnishina gladiata Müller and Hinz, p. 29, pl. 16, figs. $1-13,15$, text-fig. $8(\mathrm{~S})$.

Materials.-Three specimens.

Figure 26. (1-3) Westergaardodina sola n. sp.; (1) Chefu Formation, Wangcun section, GMPKU3031, posterior view; (2) Chefu Formation, Wangcun section, GMPKU3032, posterior view; (3) Chefu Formation, Paibi section, holotype, GMPKU3033, posterior view; (4-9) Westergaardodina tetragonia Dong, 1993; (4) Chefu Formation, Wangcun section, GMPKU3034, posterior view; (5) Chefu Formation, Wangcun section, GMPKU3035, posterior view; (6) Chefu Formation, Paibi section, GMPKU3036, posterior view; (7) Chefu Formation, Paibi section, GMPKU3037, posterior view; (8) Chefu Formation, Paibi section, GMPKU3038, posterior view; (9) Chefu Formation, Paibi section, GMPKU3039, posterior view; (10-24) Westergaardodina tricuspidata Müller, 1959; (10) Bitiao Formation, Wangcun section, GMPKU3040, posterior view; (11) Bitiao Formation, Wangcun section, GMPKU3041, posterior view; (12) Bitiao Formation, Wangcun section, GMPKU3042, posterior view; (13) Bitiao Formation, Wangcun section, GMPKU3043, posterior view; (14) Bitiao Formation, Wangcun section, GMPKU3044, posterior view; (15) Bitiao Formation, Wangcun section, GMPKU3045, posterior view; (16) Bitiao Formation, Wangcun section, GMPKU3046, posterior view; (17) Bitiao Formation, Wangcun section, GMPKU3047, posterior view; (18) Bitiao Formation, Wangcun section, GMPKU3048, posterior view; (19) Bitiao Formation, Wangcun section, GMPKU3049, posterior view; (20) Bitiao Formation, Wangcun section, GMPKU3050, posterior view; (21) Bitiao Formation, Wangcun section, GMPKU3051, posterior view; (22) Bitiao Formation, Wangcun section, GMPKU3052, posterior view; (23) Bitiao Formation, Wangcun section, GMPKU3053, posterior view; (24) Bitiao Formation, Wangcun section, GMPKU3054, posterior view; (25) Westergaardodina wimani Szaniawski, 1971, Bitiao Formation, Wangcun section, GMPKU2200, posterior view; (26) Westergaardodina sp. A, Bitiao Formation, Wangcun section, GMPKU3055, posterior view; (27) Westergaardodina sp. B, Bitiao Formation, Wa'ergang section, GMPKU3056, posterior view; (28) Yongshunella polymorpha Dong and Bergström, 2001a, Huaqiao Formation, Wangcun section, GMPKU3057, cluster; (29, 30) Furnishina cf. alata Szaniawski, 1971; (29) Huaqiao Formation, Paibi section, GMPKU3058, posterior view; (30) Huaqiao Formation, Paibi section, GMPKU3059, posterior view; (31-33) Furnishina pernica An, 1982; (31) Huaqiao Formation, Paibi section, GMPKU3060, lateral view; (32) Chefu Formation, Paibi section, GMPKU3061, lateral view; (33) Huaqiao Formation, Paibi section, GMPKU3062, posterior view; (34-36) Hunanognathus tricuspidatus Dong, 1993; (34) Huaqiao Formation, Paibi section, GMPKU3063, posterior view; (35) Huaqiao Formation, Paibi section, GMPKU3064, posterior view; (36) Huaqiao Formation, Paibi section, GMPKU3065, posterior view; (37, 38) Shandongodus priscus An, 1982; (37) Huaqiao Formation, Paibi section, GMPKU3066, posterolateral view;

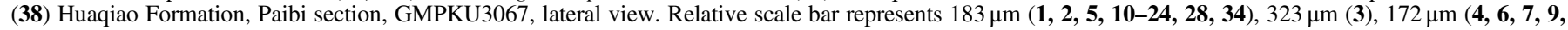
25, 29, 32, 33, 35, 36), $238 \mu \mathrm{m}(\mathbf{8}), 373 \mu \mathrm{m}(\mathbf{2 6}), 472 \mu \mathrm{m}(\mathbf{2 7}), 157 \mu \mathrm{m}(\mathbf{3 0}, \mathbf{3 1}), 139 \mu \mathrm{m}(\mathbf{3 7}, \mathbf{3 8})$. 


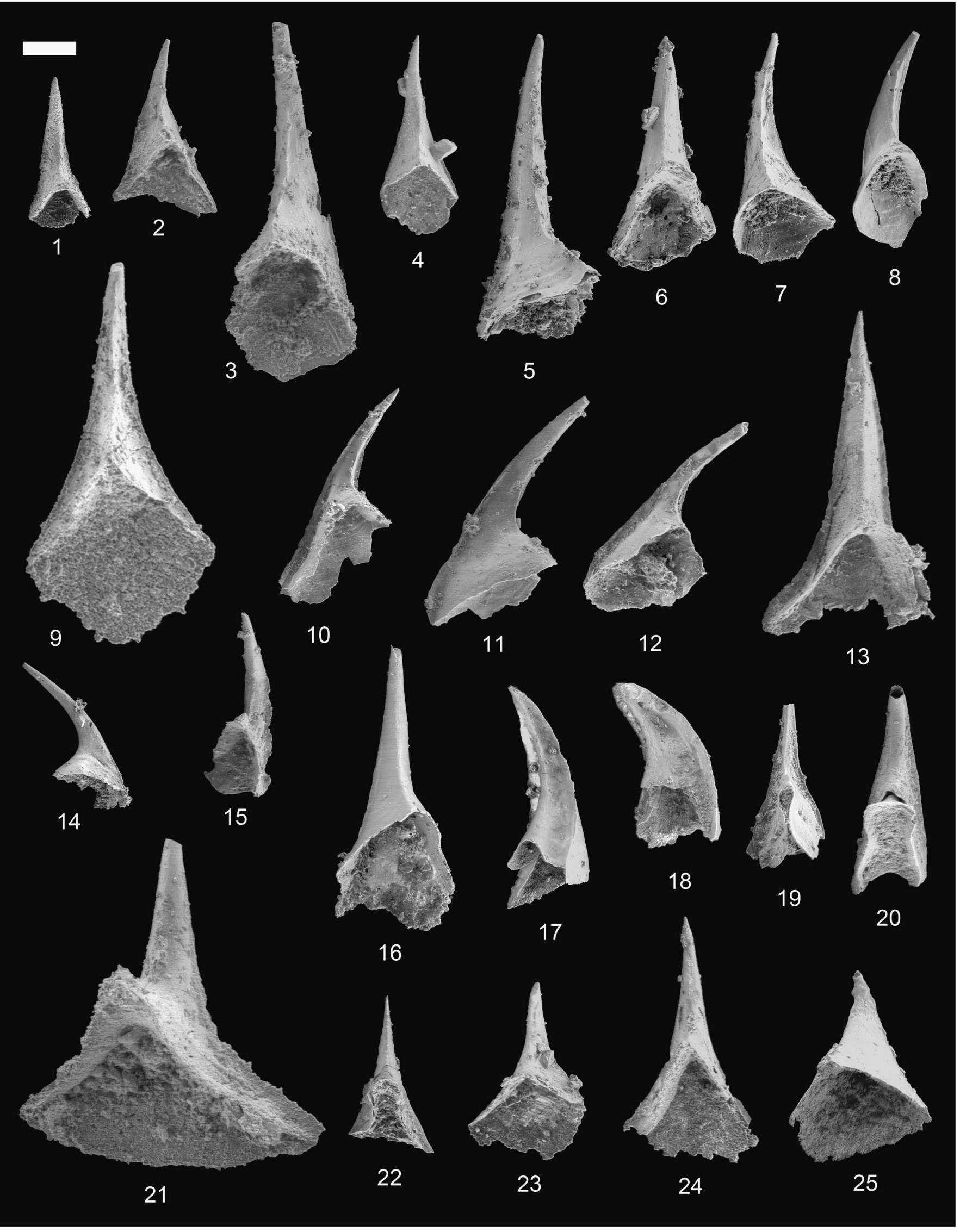


Occurrence.-Known from the Wangcun sections, where it occurs in the Westergaardodina lui-Westergaardodina ani Zone.

Remarks.-The specimens at hand agree in all respects with Müller and Hinz's (1991) species.

Furnishina cf. gladiata Müller and Hinz, 1991 Figure 27.18

cf. 1959 Scandodus n. sp. b Müller, p. 464, pl. 12, fig. 5.

cf. 1991 Furnishina gladiata Müller and Hinz, p. 29, pl. 16, figs. $1-13,15$, text-fig. 8 (S).

Materials.-Two specimens.

Occurrence.-Known from the Wangcun section, where it ranges from Shandongodus priscus-Hunanognathus tricuspidatus Zone through the Westergaardodina cf. calix-Prooneotodus rotundatus Zone.

Remarks.-Similar to Furnishina gladiata, but it differs in its anterolateral costae that do not appear as large laminae.

Furnishina kleithria Müller and Hinz, 1991

Figure 27.19, 27.20, 27.22

1991 Furnishina kleithria Müller and Hinz, p. 21, pl. 15, figs. 1-5, 7-10, 16, text-fig. 8 (P, Q).

2006 Furnishina kleithria Müller and Hinz; Qi et al., p. 186, pl. 2, fig. 7.

2008 Furnishina kleithria Müller and Hinz; Bagnoli et al., p. 112, fig. 3 (R).

Materials.-10 specimens.

Occurrence.-Known from the Wangcun section, where it ranges from the Gapparodus bisulcatus-Westergaardodina brevidens Zone through the Westergaardodina cf. calixProoneotodus rotundatus Zone.

Remarks.-The present specimens at hand agree with Furnishina kleithria as described and illustrated by Müller and Hinz (1991).

Furnishina kranzae Müller and Hinz, 1991

Figure 27.21, 27.23-27.25
1991 Furnishina kranzae Müller and Hinz, pl. 12, figs. 1, 2, 6, 8, 12-14, 18, fig. 8 (B).

Materials.-Nine specimens.

Occurrence.-Known from the Paibi and Wangcun sections, where it ranges from Westergaardodina lui-Westergaardodina ani Zone Zone through the Westergaardodina cf. calixProoneotodus rotundatus Zone.

Remarks.-The specimens at hand agree with Furnishina kranzae as described and figured by Müller and Hinz (1991).

Furnishina cf. kranzae Müller and Hinz, 1991

Figure 28.1

cf. 1991 Furnishina kranzae Müller and Hinz, pl. 12, figs. 1, 2, 6, 8, 12-14, 18, fig. 8 (B).

1993 Furnishina cf. kranzae Müller and Hinz; Dong, p. 350, pl. 4, figs. 1, 2, 5 .

2001a Furnishina cf. kranzae Müller and Hinz; Dong and Bergström, p. 961, pl. 5, fig. 9.

Materials._-18 specimens.

Occurrence.-Known from the Paibi, Wangcun and Wa'ergang sections, where it ranges from the Westergaardodina quadrata Zone through the Westergaardodina cf. calix-Prooneotodus rotundatus Zone.

Remarks.-Differs from the typical Furnishina kranzae in having indistinctly laterally deflected cusps and in the weakly developed posterior keels. Our specimens also occur in stratigraphically older strata than F. kranzae.

Furnishina longibasis Bednarczyk, 1979

Figure 28.2, 28.3

1979 Furnishina longibasis Bednarczyk, p. 427, pl. 1, figs. 1, 4.

1991 Furnishina longibasis Bednarczyk; Müller and Hinz, p. 21, pl. 11, figs. 10, 12.

2006 Furnishina longibasis Bednarczyk; Qi et al., p. 186, pl. 2, figs. 2, 4 (not 1, 3). (part)

2009 Furnishina longibasis Bednarczyk; Lee et al., p. 420, fig. 6 (3).

\footnotetext{
Figure 27. (1-9) Furnishina furnishi Müller, 1959; (1) Bitiao Formation, Wangcun section, GMPKU2601, posterior view; (2) Bitiao Formation, Wangcun section, GMPKU2602, posterior view; (3) Bitiao Formation, Wangcun section, GMPKU2603, posterior view; (4) Bitiao Formation, Wangcun section, GMPKU2604, posterior view; (5) Bitiao Formation, Wangcun section, GMPKU2605, posterior view; (6) Bitiao Formation, Wangcun section, GMPKU2606, posterior view; (7) Bitiao Formation, Wangcun section, GMPKU2607, posterior view; (8) Bitiao Formation, Wangcun section, GMPKU2608, posterior view; (9) Shenjiawan Formation, Wa'ergang section, GMPKU2609, posterior view; (10-16) Furnishina cf. furnishi Müller, 1959; (10) Bitiao Formation, Wangcun section, GMPKU2610, oblique posterior view; (11) Bitiao Formation, Wangcun section, GMPKU2611, lateral view; (12) Bitiao Formation, Wangcun section, GMPKU2612, lateral-posterior view; (13) Bitiao Formation, Wangcun section, GMPKU2613, posterior view; (14) Bitiao Formation, Wangcun section, GMPKU2614, lateral view; (15) Bitiao Formation, Wangcun section, GMPKU2615, posterior view; (16) Bitiao Formation, Wangcun section, GMPKU2616, posterior view; (17) Furnishina gladiata Müller and Hinz, 1991, Bitiao Formation, Wangcun section, GMPKU2617, oblique posterior view; (18) Furnishina cf. gladiata Müller and Hinz, 1991, Huaqiao Formation, Wangcun section, GMPKU2618, lateral-posterior view; (19, 20, 22) Furnishina kleithria Müller and Hinz, 1991; (19) Chefu Formation, Wangcun section, GMPKU2619, posterior view; (20) Chefu Formation, Wangcun section, GMPKU2620, posterior view; (22) Chefu Formation, Wangcun section, GMPKU2621, posterior view; (21) (23-25) Furnishina kranzae Müller and Hinz, 1991; (21) Bitiao Formation, Wangcun section, GMPKU2622, posterior view; (23) Bitiao Formation, Wangcun section, GMPKU2623, posterior view; (24) Bitiao Formation, Wangcun section, GMPKU2624, posterior view; (25) Bitiao Formation, Wangcun section, GMPKU2625, posterior view. Scale bar represents 132 $\mu \mathrm{m}(\mathbf{1 - 2 5})$.
} 


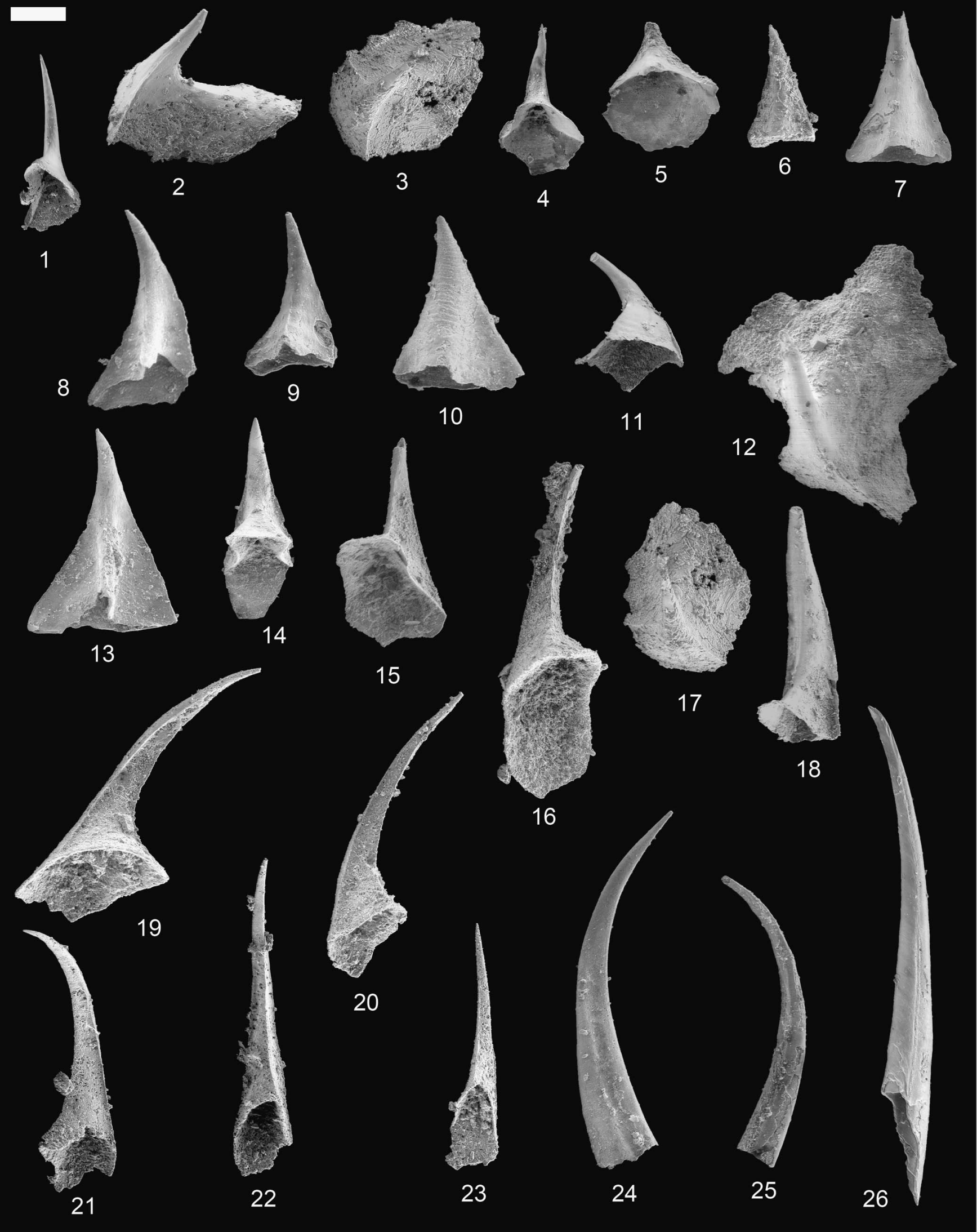


Materials.-Six specimens.

Occurrence.-Known from the Wangcun section, where it ranges from the Shandongodus priscus-Hunanognathus tricuspidatus Zone through the Westergaardodina cf. calix-Prooneotodus rotundatus Zone.

Remarks.-The specimens at hand agree in all respects with Furnishina longibasis.

Furnishina cf. ovata Müller and Hinz, 1991

Figure 28.4, 28.5

cf. 1991 Furnishina ovata Müller and Hinz, p. 22, pl. 8, figs. 7, 8, 10-22, text-fig. 8 (T).

Materials.-Four specimens.

Occurrence.- Known from the Wangcun and Wa'ergang sections, where it ranges from Westergaardodina lui-Westergaardodina ani Zone through the Eoconodontus Zone.

Remarks.-Similar to Furnishina ovata but differs in its anterolateral costae, which are not restricted to the base but extend to the cusp and are more pronounced.

\section{Furnishina pernica An, 1982}

Figure 26.31-26.33

1982 Furnishina pernica An, p. 133, pl. 4, figs. 1-4, pl. 8, fig. 4.

1993 Furnishina pernica An; Dong, pl. 5, figs. 4, 5, 9.

2001a Furnishina pernica An; Dong and Bergström, p. 961, pl. 5, figs. 1, 13.

? 2009 Furnishina pernica An; Lee et al., p. 425, fig. 8 (4).

Materials.—26 specimens.

Occurrence.-Known from the Paibi and Wangcun sections, where it ranges from the Shandongodus priscus-Hunanognathus tricuspidatus Zone through the Westergaardodina quadrata Zone.

Remarks.-The specimens at hand agree well with Furnishina pernica.

Furnishina primitiva Müller, 1959

Figure 28.6-28.10, 28.13
1959

1971

1976

1986

1987

1988

1991

text-fig. $8(\mathrm{C}, \mathrm{D})$

non. 1993 Furnishina primitiva Müller; Landing, p. 6, fig. 4 (3).

2009 Furnishina primitiva Müller; Lee et al., p. 421, fig. $6(2,4$, not 7$)$. (part)

Materials._-18 specimens.

Occurrence.-Known from the Wangcun and Wa'ergang sections, where it ranges from Westergaardodina lui-Westergaardodina ani Zone through the Cordylodus intermedius Zone.

Remarks.-The specimens at hand agree in all respects with Müller's species.

Furnishina quadrata Müller, 1959

Figure 28.12

1959 Furnishina quadrata Müller, p. 453, pl. 12, figs. 2, 4, 9, fig. 6C.

1966 Furnishina quadrata Müller; Nogami, p. 355, pl. 9, figs. 3, 4 .

1976 Furnishina quadrata Müller; Abaimova and Ergaliev, p. 392, pl. 14, figs. 3, 4, 6, 7 .

1979 Furnishina quadrata Müller; Bednarczyk, p. 428, pl. 1, figs. 15, 16.

1981 Furnishina quadrata Müller; Miller et al., fig. 4 (E).

? 1985 Furnishina quadrata Müller; Wang, p. 226, pl. 3, fig. 14, pl. 8, fig. 14 .

Figure 28. (1) Furnishina cf. kranzae Müller and Hinz, 1991, Bitiao Formation, Wangcun section, GMPKU2626, posterior view; (2, 3) Furnishina longibasis Bednarczyk, 1979; (2) Bitiao Formation, Wangcun section, GMPKU2627, lateral view; (3) Bitiao Formation, Wangcun section, GMPKU2628, lateral-anterior view; (4, 5) Furnishina cf. ovata Müller and Hinz, 1991; (4) Bitiao Formation, Wangcun section, GMPKU2629, posterior view; (5) Bitiao Formation, Wangcun section, GMPKU2630, posterior view; (6-10, 13) Furnishina primitiva Müller, 1959; (6) Bitiao Formation, Wangcun section, GMPKU2631, posterior view; (7), Shenjiawan Formation, Wa'ergang section, GMPKU2632, posterior view; (8) Shenjiawan Formation, Wa'ergang section, GMPKU2633, posterior view; (9) Shenjiawan Formation, Wa'ergang section, GMPKU2634, posterior view; (10) Shenjiawan Formation, Wa'ergang section, GMPKU2635, posterior view; (13) Shenjiawan Formation, Wa'ergang section, GMPKU2636, posterior view; (11, 14-17) Furnishina cf. quadrata Müller, 1959; (11) Bitiao Formation, Wangcun section, GMPKU2637, oblique posterior view; (14) Chefu Formation, Wangcun section, GMPKU2638, posterior view; (15) Bitiao Formation, Wangcun section, GMPKU2639, posterior view; (16) Bitiao Formation, Wangcun section, GMPKU2640, posterior view; (17) Bitiao Formation, Wangcun section, GMPKU2641, top view; (12) Furnishina quadrata Müller, 1959, Bitiao Formation, Wangcun section, GMPKU2642, top view; (18) Furnishina tortilis (Müller, 1959) Bitiao Formation, Wangcun section, GMPKU2643, posterior view; (19-23) Furnishina wangcunensis n. sp.; (19) Bitiao Formation, Wangcun section, GMPKU2644, lateral view; (20) Bitiao Formation, Wangcun section, GMPKU2645, lateral view; (21) Bitiao Formation, Wangcun section, GMPKU2646, lateral view; (22) Bitiao Formation, Wangcun section, holotype, GMPKU2647, lateral view; (23) Bitiao Formation, Wangcun section, GMPKU2648, posterior view; (24-26) Gapparodus bisulcatus (Müller, 1959); (24) Huaqiao Formation, Wangcun section, GMPKU2649, lateral view; (25) Huaqiao Formation, Wangcun section, GMPKU2650, lateral view; (26) Huaqiao Formation, Wangcun section, GMPKU2651, lateral view. Relative scale bar represents $154 \mu \mathrm{m}$ (1-26). 
? 1986 Furnishina quadrata Müller; Chen and Gong, p. 147, pl. 17, fig. 17, text-fig. 52 (2).

1991 Furnishina quadrata Müller; Müller and Hinz, p. 23, pl. 9, figs. 1-13.

2001a Furnishina quadrata Müller; Dong and Bergström, p. 961, pl. 3, fig. 16 .

? 2006 Furnishina quadrata Müller; Qi et al., p. 185, pl. 1, figs. 13-14.

Materials._Five specimens.

Occurrence.-Known only from the Wangcun section, where it occurs from the Westergaardodina quadrata Zone through the Westergaardodina lui-Westergaardodina ani Zone.

Remarks.-The specimens at hand agree closely with Müller's description.

Furnishina cf. quadrata Müller, 1959

Figure 28.11, 28.14-28.17

cf. 1959 Furnishina quadrata Müller, pl. 12, figs. 2, 4, 9, fig. 6C.

cf. 1991 Furnishina quadrata Müller; Müller and Hinz, pl. 9, figs. 1-13.

1993 Furnishina cf. quadrata Müller; Dong, p. 351, pl. 5, figs. 7, 8, 10, 18 .

2001a Furnishina cf. quadrata Müller; Dong and Bergström, p. 962 , pl. 3, fig. 13 .

Materials.—36 specimens.

Occurrence.-Known from the Paibi and Wangcun sections, where it is present in the Shandongodus priscusHunanognathus tricuspidatus Zone through the Westergaardodina cf. calix-Prooneotodus rotundatus Zone.

Remarks.-Differs from the type specimen of Furnishina quadrata in that the anterior sides of the element are not concave but slightly convex. Its first appearance also occurs stratigraphically lower than typical $F$. quadrata.

Furnishina tortilis (Müller, 1959)

Figure 28.18

1959 Scandodus tortilis Müller, p. 464, pl. 12, figs. 7, 8, 10, text-fig. 9.

1971 Scandodus tortilis Müller; Müller, pl. 2, fig. 1.

1979 Scandodus tortilis Müller; Bednarczyk, p. 434, pl. 4, fig. 15.

1981 Proscandodus tortilis (Müller); Miller in Robison, p. 113, fig. 64 (5).

1991 Furnishina tortilis (Müller); Müller and Hinz, p. 24, pl. 14, figs. 2-19, text-fig. 8 (N, O).

? 2006 Furnishina tortilis (Müller); Qi et al., p. 185, pl. 1, figs. 5-9.

2009 Furnishina tortilis (Müller); Lee et al., p. 425, fig. 8 (1, ?13).

Materials.-Three specimens.
Occurrence.-Known only from the Wangcun section, where it occurs in the Westergaardodina lui-Westergaardodina ani Zone.

Remarks. - The specimens at hand agree well with Furnishina tortilis.

Furnishina wangcunensis new species

Figure 28.19-28.23

Diagnosis.-Slender coniform elements. Cusp is distinctively recurved. The posterior costa and two anterolateral costae are sharp. Basal cavity is very deep.

Description.-Slender coniform elements with the cusp distinctively recurved toward the posterior side. Elements usually subsymmetrical but rarely asymmetrical due to lateral bending. Anterior side is convex, whereas the two posterolateral sides are concave. The posterior costa and two anterolateral costae are sharp, extending from the base up to a point that is above the recurved part of the cusp. The cross section is rounded apically and passes into subtriangular along the rest of the entire element, except for the base, where the cross section is subtriangular or irregularly rectangular. The basal cavity is very deep, with the apex above the recurved point of cusp.

Etymology.-Named for the Wangcun section in Hunan Province.

Types.-Holotype: GMPKU2647, from the Westergaardodina cf. calix-Prooneotodus rotundatus Zone, Furongian (upper Cambrian), Bitiao Formation, Wangcun section, Wangcun village, Yongshun County, Hunan Province.

Materials._-98 specimens.

Occurrence.-Known from the Wangcun section where it is present in the Westergaardodina cf. calix-Prooneotodus rotundatus Zone.

Comparison.-Furnishina wangcunensis n. sp. differs from Furnishina dayangchaensis in its more slender elements, distinctively recurved cusps, and sharp posterior costae and anterolateral costae.

Genus Hunanognathus Dong, 1993

Type species.-Hunanognathus tricuspidatus Dong, 1993.

Hunanognathus tricuspidatus Dong, 1993

Figures 20.9, 20.10, 26.34-26.36

? 1987 Westergaardodina amplicava (Müller); An, pl. 3, fig. 14.

1993 Hunanognathus tricuspidatus Dong, p. 352, pl. 3, figs. 1-3.

2001a Hunanognathus tricuspidatus Dong; Dong and Bergström, p. 965, pl. 4, figs. 2-4.

Materials.—60 specimens. 
Occurrence.-Known from the Paibi and Wangcun sections, where it ranges from the Shandongodus priscusHunanognathus tricuspidatus Zone through the Westergaardodina quadrata Zone.

Remarks.-The specimens at hand agree well with Hunanognathus tricuspidatus described and figured by Dong and Bergström (2001a). A single specimen referred to as Furnishina? sp. indet. by Müller and Hinz (1991, p. 25, pl. 14, fig. 1) was found in Zone 1 at Gum, Sweden, and a similar specimen was recovered in the present study in the lower part of the Westergaardodina quadrata Zone of the Chefu Formation. In gross mophology, both these specimens are simliar to H. tricuspidatus, but they differ from the latter in having only one small denticle. It is probable that these specimens are closely related to $H$. tricuspidatus, but additional specimens are needed to assess this possible relationship.

\section{Genus Laiwugnathus An, 1982}

Type species._Laiwugnathus laiwuensis An, 1982.

Laiwugnathus hunanensis new species Figure 21.1, 21.2

Diagnosis.-Coniform elements, triangular in outline. The anterior side is convex, whereas the posterior side is concave, with a prominent median keel. Both sides are fused along the upward arched basal margin.

Description.-Coniform elements, triangular in outline, without a clear boundary between cusp and base. Anterior side is slightly convex. Posterior side is concave and is characterized by a slender median keel ending with an opening. The keel tapers gradually upward. Both anterior and posterior sides are fused along the basal margin. No basal cavity could be observed. Lateral edge of element is straight and sharp. Basal margin is sharp and is arched upward. The end of the keel is higher than the highest part of the arched basal margin.

Etymology.-Named for its provenance in the Chinese Province of Hunan.

Types.-Holotype: GMPKU2722, from Gapparodus bisulcatusWestergaardodina brevidens Zone, middle Cambrian, Huaqiao Formation, Wangcun section, Wangcun village, Yongshun County, Hunan Province.

Materials.—Nine specimens.

Occurrence.-Present in the Wangcun section, where it occurs in the Gapparodus bisulcatus-Westergaardodina brevidens Zone.

Comparison.-Laiwugnathus hunanensis n. sp. differs from Laiwugnathus fenghuangesis An, 1982 in its much more slender median keel and the absence of a basal cavity. It differs from Laiwugnathus kouzhenensis An, 1982 in its much shorter median keel and upward-arched basal margin. The median keel of L. kouzhenensis is much longer, ending with an opening shaped like a loudspeaker and extending below the basal margin. L. hunanensis differs from Laiwugnathus graoilentus An and Mei, 1994 in that the keel of the latter is more slender and solid.

Remarks.-Specimens of various species of Laiwugnathus are very common in North China but are relatively rare in Hunan.

\section{Laiwugnathus cf. kouzhenensis An, 1982}

Figure 21.3

1982 Laiwugnathus cf. kouzhenensis An, 1982, p. 135, pl. 2, figs. 12-13.

Materials._-Five specimens.

Occurrence.-Present in the Wangcun section, where it occurs in the Westergaardodina matsushitai-Westergaardodina grandidens Zone.

Remarks.-Similar to Laiwugnathus kouzhenensis, but the specimens at hand differ in the longitudinal keel. In L. kouzhenensis, the median keel is prominent, ending with an opening shaped like a loudspeaker. In the present specimens, the boundary between the median keel and the posterior side of the upper part of the cusp is not distinct.

\section{Laiwugnathus transitans new species}

Figure 21.4-21.6

2001a Westergaardodina sp. Dong and Bergström, p. 963, pl. 1, fig. 21.

Diagnosis.-Coniform elements with a large cusp and small base. The anterior side is convex, whereas the posterior side is concave, with a prominent median rounded keel. Both sides are fused along the straight basal margin.

Description.-Coniform elements with a long, narrow cusp. The small base extends laterally, like a very short lateral projection typical of Westergaardodina. Anterior side is slightly convex. Posterior side is concave and is characterized by a rounded, median keel that is long and large that ends with cone shaped opening. Both anterior and posterior sides are fused along the basal margin. No basal cavity could be observed. Lateral edge of element is straight and sharp. Basal margin is sharp and almost straight. The end of the keel is near the basal margin.

Etymology.-_Latin, transitans, transitional.

Types.-Holotype: GMPKU2726, from Westergaardodina matsushitai-Westergaardodina grandidens Zone, middle Cambrian, Chefu Formation, Wangcun section, Wangcun village, Yongshun County, Hunan Province.

Materials._-Ten specimens.

Occurrence.-Present in the Paibi and Wangcun sections, where it ranges from the Westergaardodina matsushitai-Westergaardodina 
grandidens Zone through the Westergaardodina luiWestergaardodina ani Zone.

Comparison.-Laiwugnathus transitans $\mathrm{n}$. sp. differs from Laiwugnathus kouzhenensis in its base which inclines downwards like two short lateral projections of the genus Westergaardodina.

Remarks.-Laiwugnathus transitans $\mathrm{n}$. $\mathrm{sp}$. is probably the transitional form between Laiwugnathus and tricuspidate Westergaardodina.

\section{Genus Lugnathus new genus}

Type species.—Lugnathus hunanensis $\mathrm{n}$. gen. $\mathrm{n}$. sp.

Diagnosis.—Large, simple, coniform elements, proclined, asymmetrical and laterally compressed, with a carina on one lateral side. Anterior and posterior edges lack costae. Basal cavity is very deep, the apex of which extends nearly to the tip of the cusp.

Etymology.-In honor of the late Professor Lu Yan-hao, Nanjing Institute of Geology and Palaeontology, Chinese Academy of Sciences; Acadimician of Chinese Academy of Sciences, the name is composed from $\mathrm{Lu}$ and a derivative of Greek, gnathus, jaw.

Remarks.-In gross morphology, Lugnathus is somewhat similar to Proconodontus but differs from the latter in lacking either an anterior or posterior costa. Also, Lugnathus is a paraconodont, which is verified by our histological investigtion of specimens recovered from Hunan (Fig. 29).

Lugnathus hunanensis new genus new species

Figures 19.20, 19.21, 19.25, 19.26, 20.1-20.8, 29.1-29.4

Diagnosis.—As for the genus.

Description.-Large, hollow, coniform elements, proclined, asymmetrical, laterally compressed, with carina on one lateral side. The apex is pointed. The cusp is slender, with a pointed tip. Anterior and posterior edges lack costae. The basal cavity is very deep, the apex of which extends nearly to tip of cusp.

Etymology.-Named for Hunan Province.

Types.-Holotype: GMPKU2702, from Cordylodus intermedius Zone, Furongian (upper Cambrian), Panjiazui Formation, Wa'ergang section, Wa'ergang village, Taoyuan County, Hunan Province.

Materials.—120 specimens.

Occurrence.-Known from the Wa'ergang and Wangcun sections, where it ranges from the Eoconodontus Zone through the Cordylodus lindstromi Zone (upper part).

Genus Miaognathus new genus

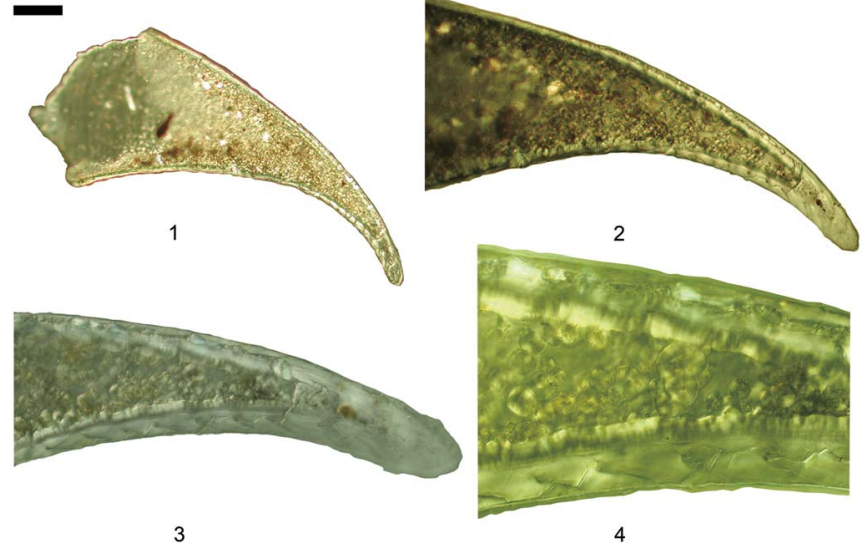

Figure 29. Conodont images using oil immersion techniques (Dong et al 2005c) with Differential Interference Contrast (Nomarski) illumination, showing pataconodont structure. (1-4) Lugnathus hunanensis n. gen. n. sp.; (1) overview, GMPKU3068; (2) close-up of (1), showing the growth lamellae of paraconodont; (3) close-up of the tip, showing the growth lamellae of paraconodont in detail; (4) close-up of (1) showing the structure of the basal tissue which intergrades with the core of calcosphere (dentine). Relative scale bar represents $46 \mu \mathrm{m}$ (1), $27 \mu \mathrm{m}$ (2), $11 \mu \mathrm{m}$ (3), $6 \mu \mathrm{m}$ (4).

Type species.—Miaognathus multicostatus $\mathrm{n}$. gen. n. sp.

Diagnosis.—Large coniform elements, proclined and asymmetrical. It is strongly laterally compressed. Basal cavity is very large and deep. The posterior edge has a costa, and the anterior edge is without costae. One to four costae are on each of the lateral sides.

Etymology.-Miao, ethnic minority group in werstern Hunan, South China; gnathus, Greek, jaw.

Miaognathus multicostatus new genus new species

Figure 21.8-21.12, 21.15, 21.16

Diagnosis.—As for the genus.

Description.—Large-sized coniform, proclined and asymmetrical. It is strongly laterally compressed. Basal cavity is very large and deep, the apex of which extends nearly to tip. The posterior edge is characterized by a sharp costa, whereas the anterior edge is without costa. One to four costae are on each of the lateral sides. Cross-section is sharp subtriangular except for the apex.

Etymology.-multicostatus, Latin, referring to the multiple costae.

Types.-Holotype: GMPKU2733 from the Eoconodontus Zone, Furongian (upper Cambrian), Shenjiawan Formation, Wa'ergang section, Wa'ergang village, Taoyuan County, Hunan Province.

Materials._20 specimens.

Occurrence.-Known from the Wa'ergang section, where it occurs in the Eoconodontus Zone.

Comparison.-Miaognathus multicostatus n. gen. n. sp. is more or less similar to species of Coelocerodontus in gross 
morphology, but it differs from the latter in its much larger size, lack of an anterior keel, and the presence of more than one costa on its lateral sides. Also, their stratigraphic ranges are different.

Remarks.-The species of Coelocerodontus are euconodonts, whereas Miaognathus multicostatus n. gen. n. sp. is probably a paraconodont.

$$
\text { Genus Muellerodus Miller, } 1980
$$

Type species.—Distacodus (?) cambricus Müller, 1959.

Remarks.-The name Muellerodus Miller, 1980 was proposed to replace Muellerina Szaniawski, 1971, which is a homonym of an ostracode genus proposed in 1965.

\section{Muellerodus cambricus (Müller, 1959)}

Figure 30.1-30.3, 30.6

1959 Distacodus (?) cambricus Müller, p. 450, pl. 14, figs. 1, 2, text-fig. 4.

1971 Oneotodus cambricus (Müller); Müller, pl. 2, fig. 3.

1979 Muellerina cambricus (Müller); Bednarczyk, p. 429, pl. 2, fig. 8 .

1981 Muellerodus cambricus (Müller); Miller in Robison, p. W112, fig. 64, 3a, b.

1982 Muellerodus pomeranensis An, p. 138, pl. 9, figs. 6, 8 (not 7).

1991 Muellerodus cambricus (Müller); Müller and Hinz, p. 29 , pl. 18, figs. 1-4, 6-13, 15, 17, text-fig. 10 (A, B).

2006 Muellerodus cambricus (Müller); Qi et al., p. 186, pl. 2, fig. 14.

2009 Muellerodus cambricus (Müller); Lee et al., p. 427, fig. 9 (3).

2011 Muellerodus cambricus (Müller); Bagnoli and Qi, p. 12, fig. $4(\mathrm{~J})$.

Materials.-Six specimens.

Occurrence.-Known from the Wangcun and Wa'ergang sections, where it ranges from the Westergaardodina luiWestergaardodina ani Zone through the Eoconodontus Zone.

Remarks.-The present specimens agree well with Muellerodus cambricus described and figured by Müller and Hinz (1991).

\section{Muellerodus guttulus Müller and Hinz, 1991}

Figure 30.4

1991 Muellerodus guttulus Müller and Hinz, p. 29, pl. 19, figs. 1-9, 11, text-fig. 10 (D).

Materials.-Two specimens.

Occurrence.-Known from the Wangcun section, where it occurs in the Westergaardodina lui-Westergaardodina ani Zone.
Remarks.-The specimens at hand agree well with those described and figured by Müller and Hinz (1991).

\section{Muellerodus? obliquus (An, 1982)}

Figure 30.5, 30.11, 30.12

1982 Proscandodus obliquus An, p. 148, pl. 9, figs. 1-5.

1993 Muellerodus? obliquus (An); Dong, pl. 5, figs. 3, 11, 17.

2001a Muellerodus? obliquus (An); Dong and Bergström, p. 968, pl. 4, fig. 10.

2006 Muellerodus? obliquus (An); Qi et al., p. 186, pl. 2, figs. 10-11.

Materials._-48 specimens.

Occurrence.-Known from the Paibi and Wangcun sections, where it ranges from the Shandongodus priscus-Hunanognathus tricuspidatus Zone through the Proconodontus Zone.

Remarks.-The present specimens are closely similar to An's species. Müller and Hinz (1991) considered Proscandodus to be a junior synonym of Furnishina. Our specimens are characterized by convex anterior and posterior sides, slender cusps, and one lateral costa that is more prominent than the other. These are features more characteristic of Muellerodus than Furnishina, and hence we refer this species to the former genus.

\section{Muellerodus? oelandicus (Müller, 1959)}

Figure 30.7-30.10

1959 Scandodus oelandicus Müller, p. 463, pl. 12, fig. 14, 15, text-fig. 10.

1983 Muellerodus oelandicus (Müller); An et al., p. 109, pl. 3, fig. 9.

1986 Proscandodus oelandicus (Müller); Chen and Gong, p. 171, pl. 34, fig. 13, text-fig. 67 (2).

1991 Muellerodus? oelandicus (Müller); Müller and Hinz, p. 29, pl. 20, figs. 1-13, fig. 10 (E, F).

1993 Muellerodus? oelandicus (Müller); Dong, pl. 3, figs. 6, 11 .

2001a Muellerodus? oelandicus (Müller); Dong and Bergström, p. 968, pl. 5, fig. 12, pl. 6, fig. 9.

2006 Muellerodus? oelandicus (Müller); Qi et al., p. 186, pl. 2, fig. 12.

2009 Muellerodus? oelandicus (Müller); Lee et al., p. 423, fig. 7 (10).

2011 Muellerodus? oelandicus (Müller); Bagnoli and Qi, p. 12 , fig. $4(\mathrm{~K})$.

Materials._-32 specimens.

Occurrence.-Known from Paibi, Wa'ergang and Wangcun sections, where it ranges from the Gapparodus bisulcatusWestergaardodina brevidens Zone through the Cordylodus intermedius Zone.

Remarks.-The specimens at hand agree closely with Müller's species.

Muellerodus pomeranensis (Szaniawski, 1971) Figure 30.13-30.21 


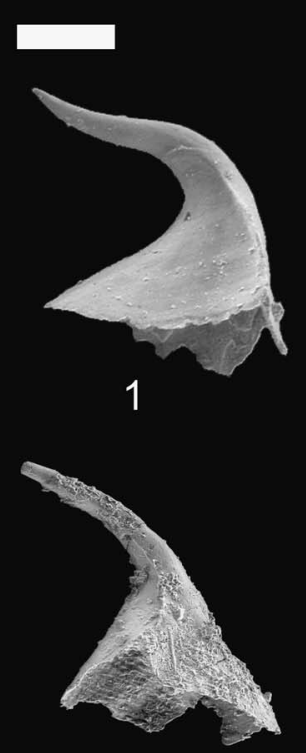

5

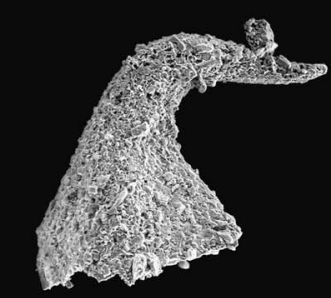

10

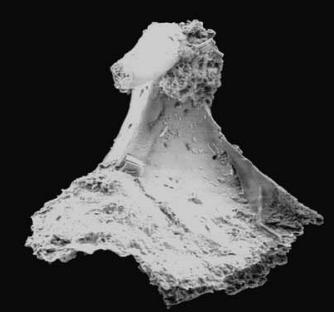

15

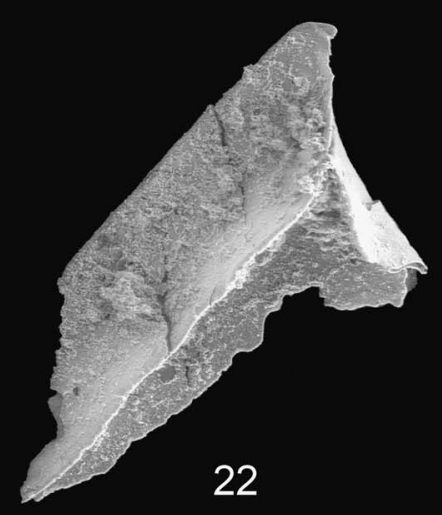

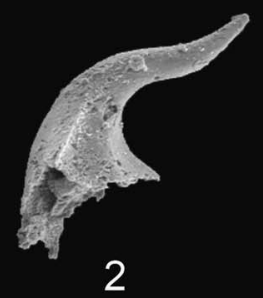
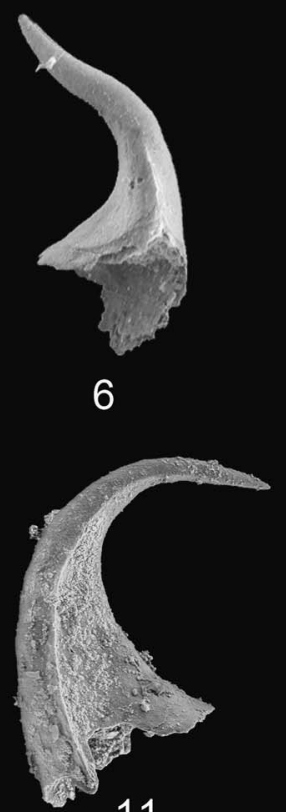

11

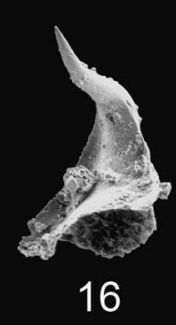

16

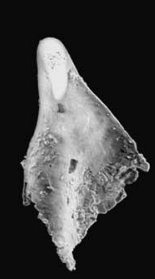

18

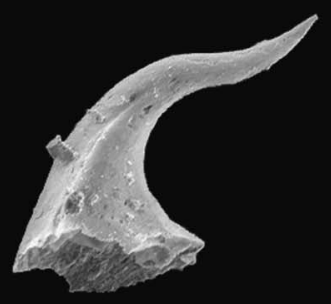

3
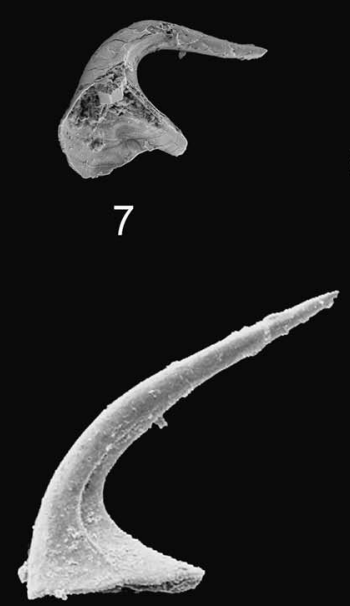

12

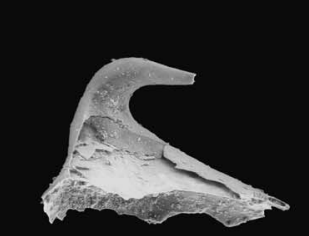

17
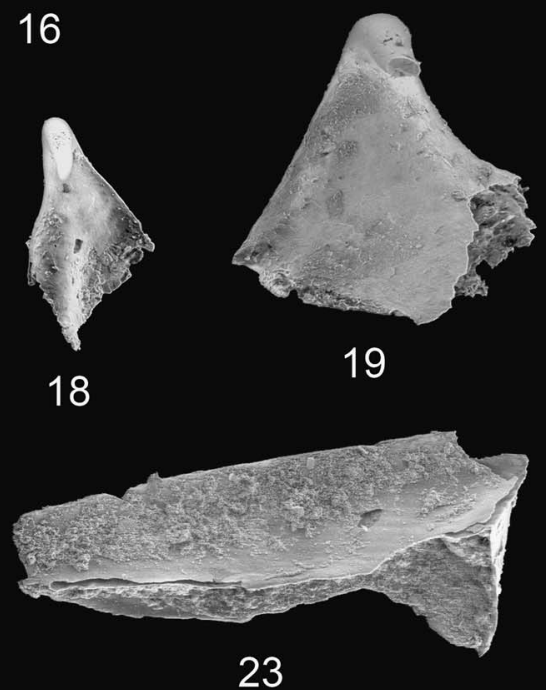
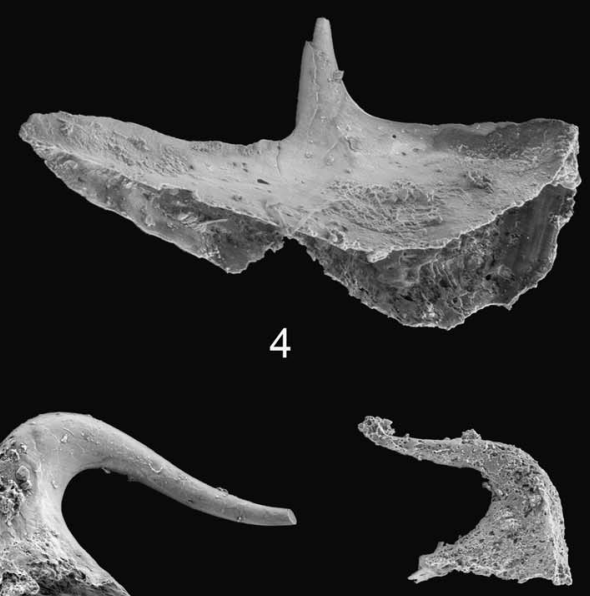

9

8
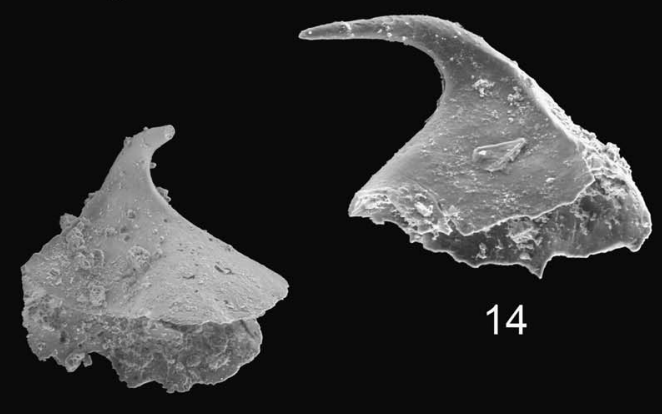

14
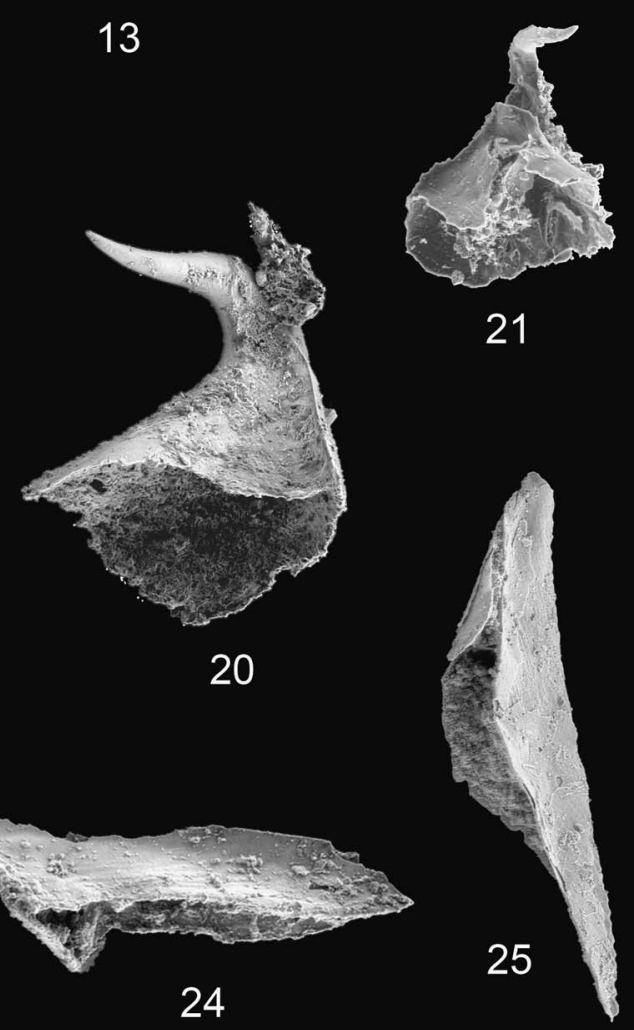
1971 Muellerina pomeranensis Szaniawski, p. 408, pl. 1, fig. 2, pl. 2, fig. 3, pl. 4, figs. 1-4.

1981 Muellerodus pomeranensis (Szaniawski); Miller et al., fig. 4 (I, J).

1982 Muellerodus pomeranensis (Szaniawski); An, p. 138, pl. 9, fig. 7 only (not figs. 6, 8), pl. 16, fig. 7, pl. 17, figs. 1, 3. (part)

1983 Muellerodus pomeranensis (Szaniawski); An et al., p. 110 , pl. 3, fig. 10 .

1987 Muellerodus pomeranensis (Szaniawski); An, p. 108, pl. 3, figs. 4, 17.

1991 Muellerodus pomeranensis (Szaniawski); Müller and Hinz, p. 30, pl. 18, figs. 5, 14, 16, 18-21, text-fig. 10 (C).

1993 Muellerodus pomeranensis (Szaniawski); Dong, pl. 2, fig. 8.

2001a Muellerodus pomeranensis (Szaniawski); Dong and Bergström, p. 968, pl. 3, fig. 12.

2006 Muellerodus pomeranensis (Szaniawski); Qi et al., p. 186, pl. 2, fig. 13.

2009 Muellerodus pomeranensis (Szaniawski); Lee et al., p. 425 , fig. 8 (3).

Materials.—24 specimens.

Occurrence.-Known from the Paibi and Wangcun sections where it ranges from the upper part of the Shandongodus priscus-Hunanognathus tricuspidatus Zone through the Westergaardodina cf. calix-Prooneotodus rotundatus Zone.

Remarks.-The specimens at hand agree closely with previously described elements of this species, except that the flank costae of some specimens are indistinct. We do not feel that this slight difference merits taxonomic separation of our specimens from Muellerodus pomeranensis.

Genus Nogamiconus Miller, 1980

Type species._Proacodus? sinensis (Nogami, 1966).

Nogamiconus sinensis (Nogami, 1966)

Figure 30.22-30.25

1966 Proacodus? sinensis Nogami, p. 356, pl. 10, figs. 12-14.

1971 Proacodus sinensis Nogami; Müller, fig. 1c.

1981 Nogamiconus sinensis (Nogami); Miller in Robison, p. W112, fig. 64 (6a, b).
1982 Gen et sp. indet. An, p. 156, pl. 8, fig. 7.

1983 Nogamiconus sinensis (Nogami); An et al., p. 110, pl. 30, fig. 11.

1991 Nogamiconus sinensis (Nogami); Müller and Hinz, p. 31, pl. 21, figs. 1-6, text-fig. 12 (A, B).

1993 Nogamiconus sinensis (Nogami); Dong, pl. 4, figs. 7-9.

2001a Nogamiconus sinensis (Nogami); Dong and Bergström, p. 969, pl. 4, figs. 11-12.

Materials._-178 specimens.

Occurrence.-Known from Paibi and Wangcun sections, where it ranges from the Shandongodus priscus-Hunanognathus tricuspidatus Zone through the Westergaardodina luiWestergaardodina ani Zone.

Remarks.-The present specimens compare well with previous descriptions and illustrations of this species. Our collections includes several clusters containing only one type of element.

Genus Proacodus Müller, 1959

Type species._Proacodus obliquus Müller, 1959.

Proacodus obliquus Müller, 1959

Figure 31.11-31.15, 31.17, 31.20-31.22, 31.25

1959 Proacodus obliquus Müller, p. 458, pl. 13, figs. 1, 4 (not fig. 2). (part)

1971 Proacodus obliquus Müller; Müller, pl. 2, fig. 2.

1979 Proacodus obliquus Müller; Bednarczyk, p. 433, pl. 1, figs. 11, 14.

1981 Proacodus obliquus Müller; Miller in Robison, p. W112, fig. 64 (4a, b).

1991 Proacodus obliquus Müller; Müller and Hinz, p. 34, pl. 22, figs. 12-23, fig. 13 (C).

Description.-Proclined, asymmetrical elements with a long lateral process. Both anterior and posterior sides are broadly rounded. The lateral process is very long and keeled on its upper side. Basal cavity is large and deep, the apex of which extends past the point of flexure of the element. Cross section is round at the apex and becomes an elongated oval at the base.

Materials.-30 specimens.

Figure 30. (1-3, 6) Muellerodus cambricus (Müller, 1959); (1) Shenjiawan Formation, Wa'ergang section, GMPKU2744, lateral view; (2) Shenjiawan Formation, Wa'ergang section, GMPKU2745, lateral view; (3) Shenjiawan Formation, Wa'ergang section, GMPKU2746, lateral view; (6) Shenjiawan Formation, Wa'ergang section, GMPKU2747, lateral view; (4) Muellerodus guttulus Müller and Hinz, 1991, Bitiao Formation, Wangcun section, GMPKU2748, posterior view; (5, 11, 12) Muellerodus? obliquus (An, 1982); (5) Bitiao Formation, Wangcun section, GMPKU2749, lateral view; (11) Bitiao Formation, Wangcun section, GMPKU2750, lateral view; (12) Huaqiao Formation, Paibi section, GMPKU2751, lateral view; (7-10) Muellerodus? oelandicus (Müller, 1959); (7) Huaqiao Formation, Wangcun section, GMPKU2752, lateral view; (8) Bitiao Formation, Wangcun section, GMPKU2753, lateral view; (9) Bitiao Formation, Wangcun section, GMPKU2754, lateral view; (10) Shenjiawan Formation, Wangcun section, GMPKU2755, lateral view; (13-21) Muellerodus pomeranensis (Szaniawski, 1971); (13) Bitiao Formation, Wangcun section, GMPKU2756, posterior view; (14) Bitiao Formation, Wangcun section, GMPKU2757, posterolateral view; (15) Bitiao Formation, Wangcun section, GMPKU2758, posterior view; (16) Bitiao Formation, Wangcun section, GMPKU2759, posterior view; (17) Bitiao Formation, Wangcun section, GMPKU2760, posterior view; (18) Bitiao Formation, Wangcun section, GMPKU2761, oblique posterior view; (19) Bitiao Formation, Wangcun section, GMPKU2762, posterior view; (20) Bitiao Formation, Wangcun section, GMPKU2763, posterior view; (21) Bitiao Formation, Wangcun section, GMPKU2764, posterior view; (22-25) Nogamiconus sinensis (Nogami, 1966); (22) Huaqiao Formation, Wangcun section, GMPKU2765, posterior view; (23) Chefu Formation, Wangcun section, GMPKU2766, posterior view; (24) Chefu Formation, Wangcun section, GMPKU2767, posterior view; (25) Chefu Formation, Wangcun section, GMPKU2768, posterior view. Relative scale bar represents $123 \mu$ m $(\mathbf{1}, \mathbf{2}, \mathbf{4}, \mathbf{6}, \mathbf{8}, \mathbf{1 1}, \mathbf{1 6}, \mathbf{1 7}, \mathbf{2 2}, \mathbf{2 5}), 117 \mu \mathrm{m}(\mathbf{3}, \mathbf{5}, \mathbf{7}, \mathbf{9}, \mathbf{1 0}, \mathbf{1 2 - 1 5}, \mathbf{1 8}-\mathbf{2 1}), 159 \mu \mathrm{m}(\mathbf{2 3}, \mathbf{2 4})$. 

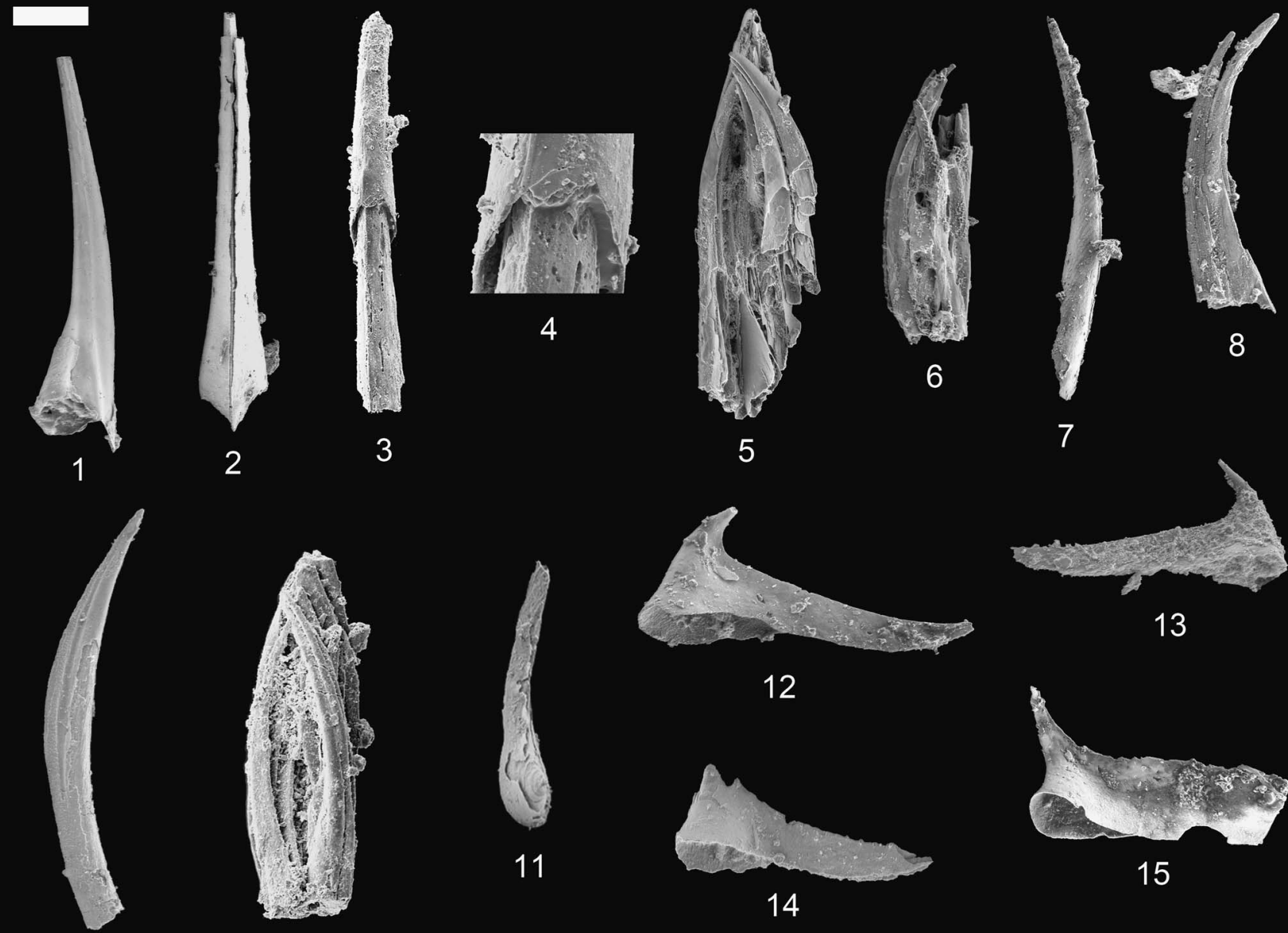

9
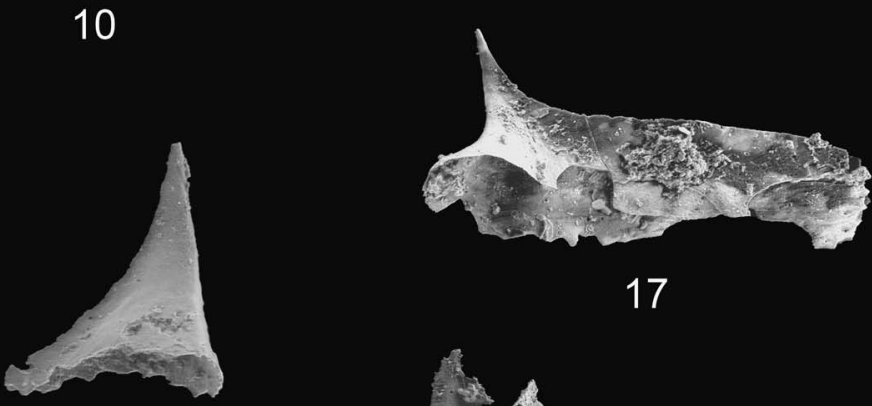

17

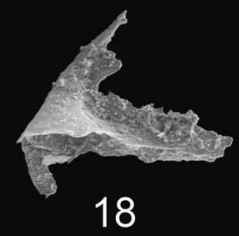

19
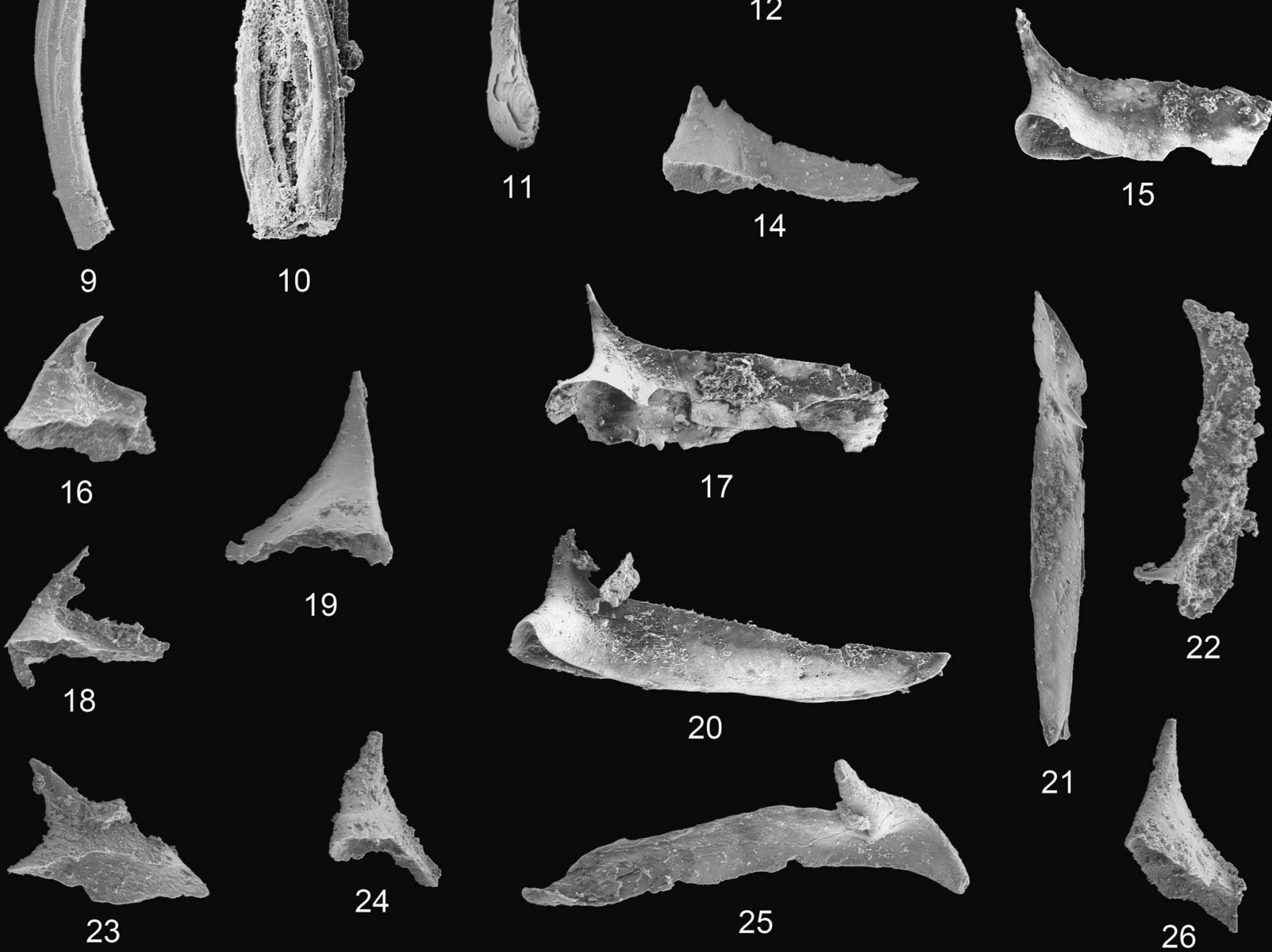
Occurrence.-Known from the Wangcun and Wa'ergang sections, where it ranges from the Westergaardodina luiWestergaardodina ani Zone through the Eoconodontus Zone.

Proacodus pulcherus (An, 1982)

Figures 23.1-23.6, 31.16, 31.18, 31.19, 31.23, 31.24, 31.26

1959 Proacodus obliquus Müller, p. 458, pl. 13, fig. 2 only. (part)

1982 Muellerodus pulcherus An, p. 139, pl. 9, figs. 13, 15, pl. 10, figs. 12, 14.

1991 Proacodus pulcherus (An); Müller and Hinz, p. 34, pl. 22, figs. 3-5, 7-11, text-fig. 13 (A, B).

2000 Proacodus obliquus Müller; Dubinina, p. 172, pl. 3, figs. 4-6.

2006 Proacodus pulcherus (An); Qi et al., p. 187, pl. 3, fig. 18.

2011 Proacodus pulcherus (An); Bagnoli and Qi, p. 12, fig. 4 (L).

Description.-Coniform elements, proclined, asymmetrical, with a short lateral process. Both anterior and posterior sides are broadly rounded. The lateral process is short and keeled on its upper side. Basal cavity is large and deep, with the apex extending past the point of flexure of the element. Cross section is round at the apex and becomes tear-shaped at the base.

Materials.—40 specimens.

Occurrence.-Known from the Wangcun and Wa'ergang sections, where it ranges from the Westergaardodina luiWestergaardodina ani Zone through the Proconodontus Zone.

\section{Proacodus cf. pulcherus (An, 1982)}

Figure 23.7

cf. 1959 Proacodus obliquus Müller, p. 458, pl. 13, fig. 2, only. (part)

cf. 1982 Muellerodus pulcherus An, p. 139, pl. 9, figs. 13, 15, pl. 10, figs. 12, 14.

cf. 1991 Proacodus pulcherus (An); Müller and Hinz, p. 34, pl. 22, figs. 3-5, 7-11, text-fig. 13 (A, B).

Description.-Coniform elements, proclined, asymmetrical, with a long lateral process. Both anterior and posterior sides are broadly rounded. The long lateral process extends horizontally and then upward and has a keel on its upper side. Basal cavity large and deep, with the apex extending past the point of flexure of the element. Cross section is round at the apex and becomes tear-shaped at the base.

Materials.-Three specimens.

Occurrence.-Known from Wa'ergang sections, where it occurs in the Proconodontus Zone.

Remarks.-This form is similar to Proacodus pulcherus, but it differs in its longer process, which extends upward. Also, the apex of the present species is straight, whereas the apex of $P$. pulcherus is twisted.

Genus Prooneotodus Müller and Nogami, 1971

Type species.—Oneotodus gallatini Müller, 1959.

Prooneotodus gallatini (Müller, 1959)

Figures 24.9, 24.10, 24.12-24.32, 32.1-32.15, 32.17-32.21

1959 Oneotodus gallatini Müller, p. 457, pl. 13, figs. 5-10, $12,18$.

1971 Oneotodus gallatini Müller; Druce and Jones, p. 81, pl. 9, figs. 9a-c, pl. 10, figs. 9a-10c, text-figs. 26f, g.

1973 Oneotodus gallatini Müller; Özgül and Gedik, p. 48, pl. 1, figs. 1, 20.

1980 Oneotodus gallatini Müller; Lee, pl. 1, fig. 4.

1981 Prooneotodus gallatini (Müller); Miller in Robison, p. W113, fig. 64 (2a-c).

1981 Prooneotodus gallatini (Müller); Miller et al., fig. $4 \mathrm{~K}-\mathrm{M}$.

1982 Prooneotodus gallatini (Müller); An, p. 144, pl. 11, figs. 5-6, 9-14, pl. 16, fig. 13.

1982 Prooneotodus gallatini (Müller); Fortey et al., p. 125, text-figs. $9(\mathrm{H}, \mathrm{O})$.

1983 Prooneotodus gallatini (Müller); An et al., p. 128, pl. 5, fig. 7.

1983 Prooneotodus gallatini (Müller); Azmi, p. 379, pl. 3, figs. 3, 5.

1985 Prooneotodus gallatini (Müller); Wang, p. 235, pl. 3, figs. 23-25, pl. 5, figs. 4, 5, pl. 8, figs. 12, 21, pl. 12, figs. 22, 26, pl. 13, fig. 10, pl. 14, fig. 5 .

1986 "Prooneotodus" gallatini (Müller); Chen and Gong, p. 166, pl. 22, figs. 13, 17 (not 15, 16), pl. 23, figs. 2-3,

Figure 31. (1-4) Paibiconus proarcuatus Dong, 1993; (1) Chefu Formation, Wangcun section, GMPKU2769, posterolateral view; (2) Chefu Formation, Wangcun section, GMPKU2770, anterior view; (3) Huaqiao Formation, Wangcun section, GMPKU2002, anterior view; (4) Close-up view of the broken surface of (3), showing protoconodont structure; (5-10) Phakelodus tenuis (Müller, 1959); (5) Chefu Formation, Wangcun section, GMPKU2771, cluster; (6) Bitiao Formation, Wangcun section, GMPKU2772, cluster; (7) Bitiao Formation, Wangcun section, GMPKU2773, lateral view; (8) Bitiao Formation, Wangcun section, GMPKU2774, cluster; (9) Shenjiawan Formation, Wa'ergang section, GMPKU2775, lateral view; (10) Shenjiawan Formation, Wa'ergang section, GMPKU2776, cluster; (11-15, 17, 20-22, 25) Proacodus obliquus Müller, 1959; (11) Bitiao Formation, Wangcun section, GMPKU2777, top view; (12) Bitiao Formation, Wangcun section, GMPKU2778, posterior view; (13) Bitiao Formation, Wangcun section, GMPKU2779, posterior view; (14) Bitiao Formation, Wangcun section, GMPKU2780, posterior view; (15) Bitiao Formation, Wangcun section, GMPKU2781, posterior view; (17) Bitiao Formation, Wangcun section, GMPKU2782, posterior view; (20) Bitiao Formation, Wangcun section, GMPKU2783, posterior view; (21) Bitiao Formation, Wangcun section, GMPKU2784, top view from anterior side; (22) Bitiao Formation, Wangcun section, GMPKU2785, posterior view; (25) Shenjiawan Formation, Wa'ergang section, GMPKU2786, top view from anterior side; $(\mathbf{1 6}, \mathbf{1 8}, \mathbf{1 9}, \mathbf{2 3}, \mathbf{2 4}, \mathbf{2 6})$ Proacodus pulcherus (An, 1982); (16) Bitiao Formation, Wangcun section, GMPKU2787, posterior view; (18) Bitiao Formation, Wangcun section, GMPKU2788, posterior view; (19) Bitiao Formation, Wangcun section, GMPKU2789, posterior view; (23) Bitiao Formation, Wangcun section, GMPKU2790, posterior view; (24) Bitiao Formation, Wangcun section, GMPKU2791, posterior view; (26) Bitiao Formation, Wangcun section, GMPKU2792, posterior view. Relative scale bar represents $311 \mu \mathrm{m}(\mathbf{1}), 362 \mu \mathrm{m}(\mathbf{2}), 227 \mu \mathrm{m}(\mathbf{3}), 71 \mu \mathrm{m}(\mathbf{4}), 130 \mu \mathrm{m}$ $(\mathbf{5 , 8 , 9 , 1 2 - 2 6 ) ,} 188 \mu \mathrm{m}(\mathbf{6}), 160 \mu \mathrm{m}(\mathbf{7}), 119 \mu \mathrm{m}(\mathbf{1 0}), 100 \mu \mathrm{m}(\mathbf{1 1})$. 
7, 10, 16-19, pl. 24, fig. 12, text-figs. 64 (2, 5, not 3). (part)

1987 Prooneotodus gallatini (Müller); An, p. 112, pl. 2, figs. 1, 2, 5, 6, 11, 15.

1987 Prooneotodus gallatini (Müller); Buggisch and Repetski, p. 159, pl. 8, fig. 2.

1991 Prooneotodus gallatini (Müller); Müller and Hinz, p. 37, pl. 24, figs. 1-28, 29.

2000 Prooneotodus gallatini (Müller); Dubinina, p. 178, pl. 4, figs. 22, 29, 30.

2000 "Prooneotodus" mitriformis Dubinina, p. 178, pl. 4, fig. 28.

2000 Prooneotodus rotundatus (Druce et Jones); Zhao et al., p. 216, pl. 23, figs. 25,28 .

2002a Prooneotodus gallatini (Müller); Lee, p. 165, pl. 2, fig. 10.

2002b Prooneotodus gallatini (Müller); Lee, p. 27, pl. 2, fig. 7.

2004 Prooneotodus gallatini (Müller); Lee, p. 60, fig. 5 (N).

2007 Prooneotodus gallatini (Müller); Landing et al., p. 922, fig. $9(\mathrm{~d}, \mathrm{e})$.

2009 Prooneotodus gallatini (Müller); Lee et al., p. 423, fig. 7 (12, 15), p. 425, fig. 8 (16), p. 427, fig. 9 (2).

2011 Prooneotodus gallatini (Müller); Bagnoli and Qi, p. 12, fig. 4 (C).

Description.-Moderate to small coniform elements, erect to proclined, symmetrical to asymmetrical. The apex is pointed. Both anterior and posterior sides are rounded. No keels or costae are present. Basal cavity is deep, with the apex extending past the point of flexure of the element or even nearly to its tip. The cross section is round at the apex and changes to variably oval at the base.

Materials.-300 specimens.

Occurrence.- Known from the Wangcun and Wa'ergang sections, where it ranges from the Westergaardodina lui-Westergaardodina ani Zone through the Cordylodus intermedius Zone.

Prooneotodus rotundatus (Druce and Jones, 1971) Figure 32.16, 32.22-32.29

1971 Coelocerodontus rotundatus Druce and Jones, p. 62, pl. 9, figs. 10-13, text-figs. 22c, d.

1973 Proconodontus cf. rotundatus (Druce and Jones); Müller, p. 43, pl. 3, figs. 1-3.
1976 Prooneotodus rotundatus (Druce and Jones); Miller and Paden, p. 596, pl. 1, figs. 24, 25.

1982 Prooneotodus rotundatus (Druce and Jones); An, p. 144, pl. 4, fig. 12, pl. 11, figs. 1-4, 7, 8 .

1982 Prooneotodus rotundatus (Druce and Jones); Fortey et al., p. 125, text-fig. 9 (J, M).

1983 Prooneotodus rotundatus (Druce and Jones); An et al., p. 129 , pl. 5, fig. 6 .

1985 Prooneotodus rotundatus (Druce and Jones); Wang, p. 236, pl. 3, figs. 5-7, pl. 6, fig, 13, pl. 7, figs. 7, 8, pl. 8 , fig. 6, pl. 9, fig. 2, pl. 10, fig. 9, pl. 12, fig. 6, pl. 13, figs. 8, ?32.

1986 "Prooneotodus" rotundatus (Druce and Jones); Chen and Gong, p. 167, pl. 22, figs. 1-4 (not 5), 6, 9-11, 18, 20, pl. 23, figs. 1, 9, 12, 14, 20 (not pl. 26, fig. 9), text-fig. 64 (1). (part)

1987 Prooneotodus rotundatus (Druce and Jones); s.f. Dong, p. 170, pl. 1, fig. 29, text-fig. 3M.

2000 Prooneotodus rotundatus (Druce and Jones); Dubinina, p. 179, pl. 4, figs. 26, 27.

2001 Prooneotodus rotundatus (Druce and Jones); Lee, p. 449, fig. 6 (5).

2002 Prooneotodus rotundatus (Druce and Jones); Lee, p. 165, pl. 2, fig. 8.

2002 Prooneotodus rotundatus (Druce and Jones); Lee, p. 27, pl. 2, fig. 8 .

2004 Prooneotodus rotundatus (Druce and Jones); Lee, p. 60, fig. 5 (I).

2009 Prooneotodus rotundatus (Druce and Jones); Lee et al., p. 427, fig. 9 (1).

Description.-Coniform elements, moderate to small, proclined and symmetrical. The apex is pointed. Both anterior and posterior sides are rounded. No keels or costae are present. Basal cavity is very deep, with the apex extending nearly to the tip of the element. The cross section is circular through the small cusp and base.

Materials._-90 specimens.

Occurrence.-Known from the Wangcun and Wa'ergang sections, where it ranges from Westergaardodina cf. calix-Prooneotodus rotundatus Zone through the Cordylodus intermedius Zone.

Figure 32. (1-15, 17-21) Prooneotodus gallatini Müller, 1959; (1) Shenjiawan Formation, Wa'ergang section, GMPKU2856, lateral view; (2) Shenjiawan Formation, Wa'ergang section, GMPKU2857, lateral view; (3) Shenjiawan Formation, Wa'ergang section, GMPKU2858, lateral view; (4) Shenjiawan Formation, Wa'ergang section, GMPKU2859, lateral view; (5) Shenjiawan Formation, Wa'ergang section, GMPKU2860, lateral view; (6) Shenjiawan Formation, Wa'ergang section, GMPKU2861, lateral view; (7) Shenjiawan Formation, Wa'ergang section, GMPKU2862, oblique posterior view from base; (8) Shenjiawan Formation, Wa'ergang section, GMPKU2863, lateral view; (9) Shenjiawan Formation, Wa'ergang section, GMPKU2864, lateral view; (10) Shenjiawan Formation, Wa'ergang section, GMPKU2865, lateral view; (11) Shenjiawan Formation, Wa'ergang section, GMPKU2866, lateral view; (12) Shenjiawan Formation, Wa'ergang section, GMPKU2867, lateral view; (13) Shenjiawan Formation, Wa'ergang section, GMPKU2868, lateral view; (14) Shenjiawan Formation, Wa'ergang section, GMPKU2869, lateral view; (15) Shenjiawan Formation, Wa'ergang section, GMPKU2870, lateral view; (17) Shenjiawan Formation, Wa'ergang section, GMPKU2871, lateral view; (18) Shenjiawan Formation, Wa'ergang section, GMPKU2872, lateral view; (19) Shenjiawan Formation, Wa'ergang section, GMPKU2873, lateral view; (20) Shenjiawan Formation, Wa'ergang section, GMPKU2874, lateral view; (21) Shenjiawan Formation, Wa'ergang section, GMPKU2875, lateral view; (16, 22-29) Prooneotodus rotundatus (Druce and Jones, 1971); (16) Bitiao Formation, Wangcun section, GMPKU2876, lateral view; (22) Shenjiawan Formation, Wa'ergang section, GMPKU2877, lateral view; (23) Shenjiawan Formation, Wa'ergang section, GMPKU2878, lateral view; (24) Shenjiawan Formation, Wa'ergang section, GMPKU2879, cluster, lateral view; (25) Shenjiawan Formation, Wa'ergang section, GMPKU2880, lateral view; (26) Shenjiawan Formation, Wa'ergang section, GMPKU2881, lateral view; (27) Shenjiawan Formation, Wa'ergang section, GMPKU2882, lateral view; (28) Shenjiawan Formation, Wa'ergang section, GMPKU2883, lateral view; (29) Shenjiawan Formation, Wa'ergang section, GMPKU2884, lateral view. Relative scale bar represents $130 \mu \mathrm{m}(\mathbf{1 - 1 3}, \mathbf{1 6 - 2 9})$, 138 $\mu \mathrm{m}(\mathbf{1 4}$, 15). 


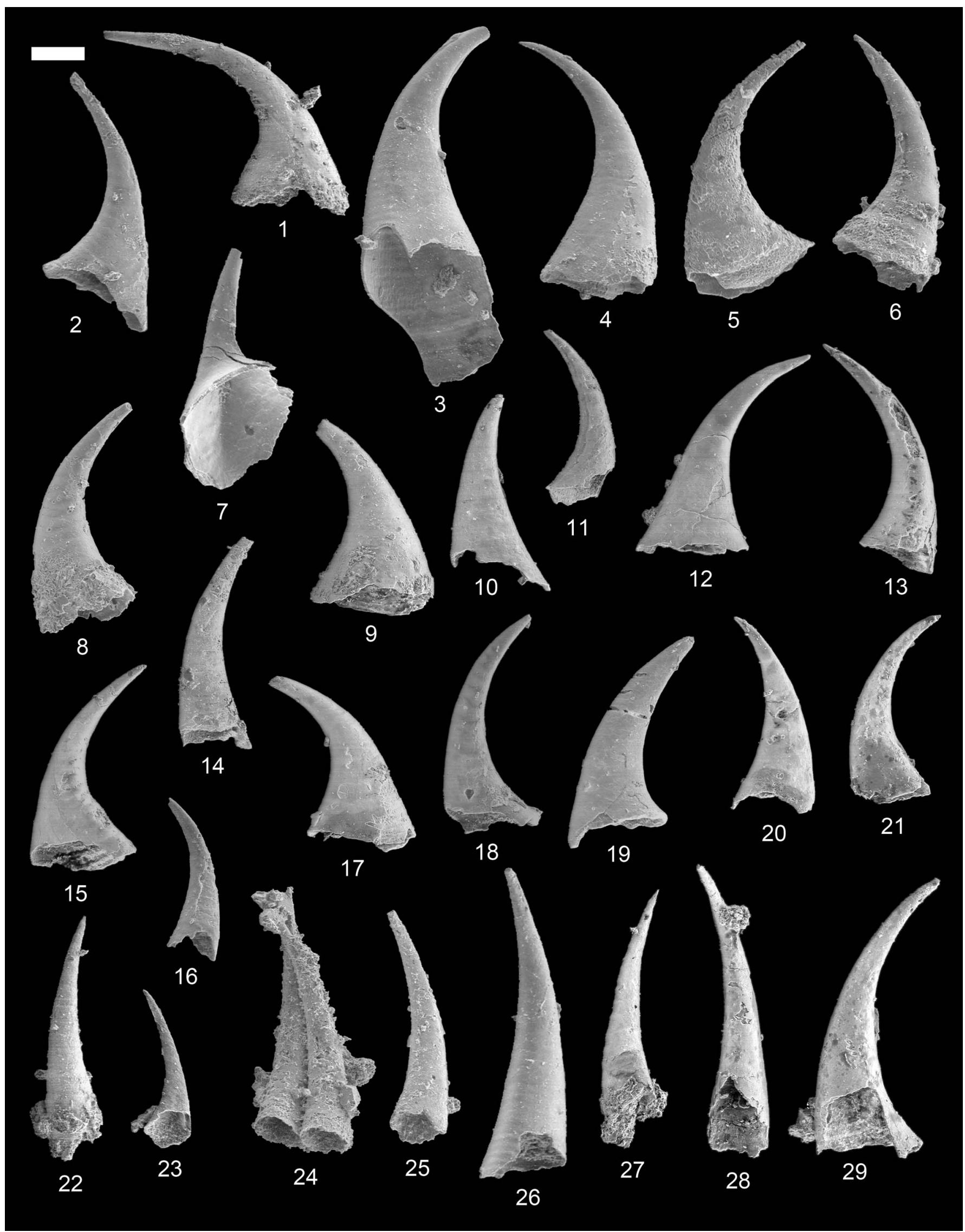


Remarks.-Prooneotodus rotundatus differs from Prooneotodus gallatini in its circular cross section and deeper basal cavity. In addition, elements of the former taper gradually, whereas elements of the latter taper relatively rapidly. In gross morphology, $P$. rotundatus resembles Millerodontus intermedius $\mathrm{n}$. gen. n. sp., but the latter is recognized as a primitive euconodont in the light of histological investigation. Accordingly, some published specimens previously assigned to $P$. rotundatus probably should be reassigned to $M$. intermedius, but this could only be done by means of histological investigation.

\section{Prooneotodus terashimai (Nogami, 1967)}

$$
\text { Figure 33.1-33.8 }
$$

1967 Oneotodus terashimai Nogami, p. 217, pl. 1, figs. 14-16.

1985 Prooneotodus terashimai cylindricum An and $\mathrm{Hu}$, pl. 1, fig. 1.

1987 Prooneotodus terashimai cylindricum $\mathrm{An}$ and $\mathrm{Hu}$; AN, p. 113, pl. 1, figs. 1-3.

2000 Prooneotodus terashimai kazakhstanica Dubinina, p. 179, pl. 4, figs. 19, 19a, 20, 20a.

2000 Phakelodus terashimai (Nogami); Göncüoğlu and Kozur, p. 599, fig. 4 (d).

? 2009 Prooneotodus terashimai (Nogami); Lee et al., p. 427, fig. 9 (11).

Description.-Coniform elements, moderate to small, and symmetrical. The cusp is small and hook-like. The base is slender and cylindrical. Both anterior and posterior edges are rounded. No keels or costae are present. Basal cavity is very deep, and the apex extends past the point of flexure of the element.

Materials._-20 specimens.

Occurrence.-Known from the Wangcun and Wa'ergang sections, where it ranges from the Westergaardodina luiWestergaardodina ani Zone through the Cordylodus proavus Zone.

Remarks.-Prooneotodus terashimai is characterized by the minute and hook-like cusp. An and Hu (1985) erected a new subspecies Prooneotodus terashimai cylindricum. The only difference between them is that the latter is much slender in gross morphology. It is considered as intraspecific variation herein.

\section{Prooneotodus? sp. A}

Figure 33.9

Description.-Large coniform element with pointed apex. There is no conspicuous junction between cusp and base. The anterior side is slightly convex, whereas the posterior side is strongly convex. Keels and costae are lacking. The cross-section is circular at the apex and becomes roundly triangular in the rest of the element. Basal cavity is large and extends nearly to tip.

Materials.-Only one specimen.

Occurrence.-Known from the Wa'ergang section, where it occurs in the Eoconodontus Zone.

Genus Prosagittodontus Müller and Nogami, 1971

Type species.—Sagittodontus dalmani Müller, 1959.

\section{Prosagittodontus compressus new species}

Figure 33.10, 33.11

1994 Laiwugnathus sagittatus An and Mei, p. 537, pl. 1, figs. 28, 29.

2001a Prosagittodontus? sp. Dong and Bergström, p. 963, pl. 1, figs. 17, 18.

Diagnosis.-A species of Prosagittodontus with two lateral projections inclining downward, with the outer parts strongly compressed. A third projection becomes a rounded median keel or an indistinct bulge. The basal cavity is moderately large and deep.

Description.-Coniform elements shaped like arrowheads in outline. The apical angle is less than $90^{\circ}$. From the pointed tip, the flanks diverge in an almost straight line, separating into two lateral projections that are strongly compressed in the outer parts, with sharp costae on the margins. A third projection becomes a rounded median keel or an indistinct bulge. The anterior side of elements is flattened, whereas the posterior side is concave. The basal cavity is moderately large and deep.

Etymology.—compressus, Latin, compressed.

Figure 33. (1-8) Prooneotodus terashimai (Nogami, 1967); (1) Bitiao Formation, Wangcun section, GMPKU2885, lateral view; (2) Bitiao Formation, Wangcun section, GMPKU2886, lateral view; (3) Bitiao Formation, Wangcun section, GMPKU2887, lateral view; (4) Bitiao Formation, Wangcun section, GMPKU2888, lateral view; (5) Bitiao Formation, Wangcun section, GMPKU2889, lateral view; (6) Bitiao Formation, Wangcun section, GMPKU2890, lateral view; (7) Bitiao Formation, Wa'ergang section, GMPKU2891, lateral view; (8) Shenjiawan Formation, Wa'ergang section, GMPKU2892, lateral view; (9) Prooneotodus? sp. A, Shenjiawan Formation, Wa'ergang section, GMPKU2893, posterior view; (10, 11) Prosagittodontus compressus n. sp.; (10) Chefu Formation, Wangcun section, holotype, GMPKU2894, anterior view; (11) Chefu Formation, Wangcun section, GMPKU2895, posterior view; (12-28) Prosagittodontus dalmani (Müller, 1959); (12) Bitiao Formation, Wangcun section, GMPKU2896, posterior view; (13) Bitiao Formation, Wangcun section, GMPKU2897, posterior view; (14) Bitiao Formation, Wangcun section, GMPKU2898, posterior view; (15) Bitiao Formation, Wangcun section, GMPKU2899, posterior view; (16) Bitiao Formation, Wangcun section, GMPKU2900, posterior view; (17) Bitiao Formation, section, Wa'ergang GMPKU2901, posterior view; (18) Shenjiawan Formation, Wa'ergang section, GMPKU2902, oblique posterior view; (19) Bitiao Formation, Wangcun section, GMPKU2903, posterior view; (20) Bitiao Formation, Wangcun section, GMPKU2904, posterior view; (21) Bitiao Formation, Wangcun section, GMPKU2905, posterior view; (22) Bitiao Formation, Wangcun section, GMPKU2906, oblique posterior view; (23) Shenjiawan Formation, Wa'ergang section, GMPKU2907, posterior view; (24) Shenjiawan Formation, Wa'ergang section, GMPKU2908, posterior view; (25) Shenjiawan Formation, Wa'ergang section, GMPKU2909, posterior view; (26) Shenjiawan Formation, Wa'ergang section, GMPKU2910, posterior view; (27) Shenjiawan Formation, Wa'ergang section, GMPKU2911, posterior view; (28) Shenjiawan Formation, Wa'ergang section, GMPKU2912, oblique posterior view. Relative scale bar represents $137 \mu \mathrm{m}$ (1-19, 21-28), 144 $\mu \mathrm{m}(\mathbf{2 0})$. 


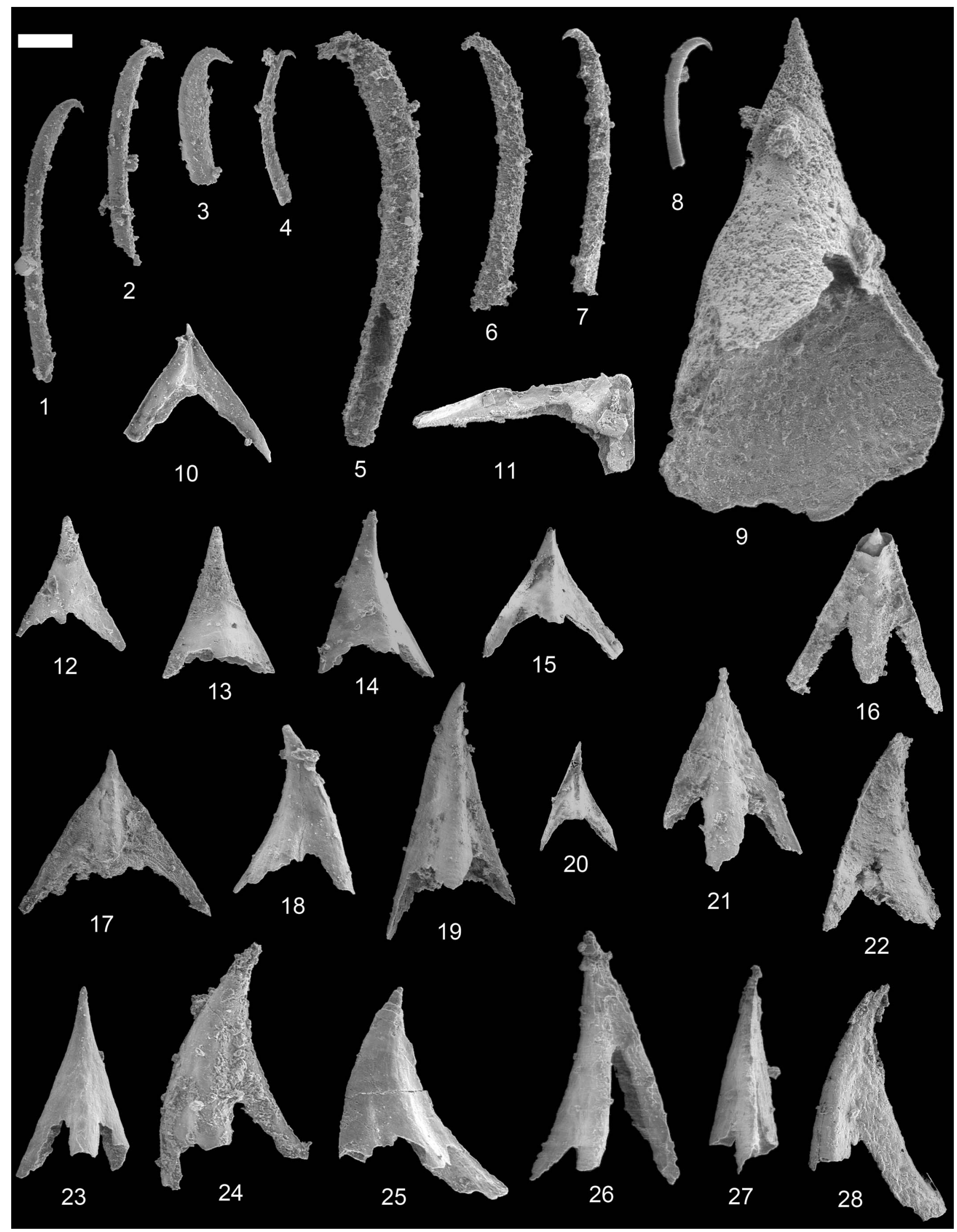


Types.-Holotype: GMPKU2894, from the Westergaardodina matsushitai-Westergaardodina grandidens Zone, Chefu Formation, Wangcun section, Wangcun village, Yongshun county, Hunan Province.

Materials.—Nine specimens.

Occurrence.-Known from the Wangcun and Paibi sections, where it ranges from the Westergaardodina quadrata Zone through the Westergaardodina lui-Westergaardodina ani Zone.

Remarks.-Prosagittodontus compressus $\mathrm{n}$. sp. appears to be the transitional form among Prosagittodontus, Laiwugnathus, and tricuspidate Westergaardodina. However, the outline of Laiwugnathus is triangular or subtriangular, while tricuspidate Westergaardodina has a median projection. Accordingly, this species is assigned to Prosagittodontus herein.

Prosagittodontus dalmani (Müller, 1959)

Figure 33.12-33.28

1959 Sagittodontus dalmani Müller, p. 460, pl. 14, figs. 5, 7, 10.

1971 Sagittodontus dalmani Müller; Müller, pl. 1, fig. 8.

1978 Prosagittodontus dalmani (Müller); Abaimova, p. 501, pl. 8, figs. 3, 5, 7 .

1981 Prosagittodontus dalmani (Müller); Miller in Robison, p. W114, fig. 65. 2a, b.

1982 Prosagittodontus dalmani (Müller); An, p. 147, pl. 5, fig. 6.

1986 Prosagittodontus dalmani (Müller); Chen et al., p. 369, pl. 2, figs. 14, 15.

1987 Prosagittodontus dalmani (Müller); An, p. 113, pl. 3, figs. 23, 24.

1991 Prosagittodontus dalmani (Müller); Müller and Hinz, p. 37, pl. 25, figs. 1-22, text-fig. 14 (B).

2002 Prosagittodontus dalmani (Müller); Lee, p. 25, pl. 1, fig. 15.

2009 Prosagittodontus dalmani (Müller); Lee et al., p. 427, fig. 9.6.

Materials.—90 specimens.

Occurrence.-Known from the Wangcun and Paibi sections, where it ranges from the Westergaardodina matsushitaiWestergaardodina grandidens Zone through the Cordylodus proavus Zone.

Remarks.-The specimens at hand agree well with those described and figured by Müller (1959) and Müller and Hinz (1991). The median projection of Prosagittodontus dalmani is prominent and extends posteriorly, resulting in a crudely triangular basal cross-section of the element. So, P. dalmani differs from Prosagittodontus compressus.

Prosagittodontus cf. eureka (Müller, 1959)

Figure 25.1, 25.2

1959 cf. Sagittodontus eureka Müller, p. 461, pl. 14, fig. 6.

1973 cf. Prosagittodontus eureka (Müller); Müller, p. 45, pl. 5, figs. 1-2.
1982 Prosagittodontus eureka (Müller); An, p. 147, pl. 5, figs. 1-2.

1982 Prosagittodontus aff. eureka (Müller); An, p. 148, pl. 5, figs. 4, 8.

2011 Prosagittodontus aff. eureka (Müller); Bagnoli and Qi, p. 12, fig. 4 (D, E).

Materials._Four specimens.

Occurrence.-Known from Wangcun section, where it occurs Westergaardodina lui-Westergaardodina ani Zone.

Remarks.-The specimens at hand are similar to those described and figured by Müller $(1959,1973)$, but the median keel on the posterior side of the present specimens is much less distinct than that of Prosagittodontus eureka s. s. An (1982) described and figured four specimens assigned to P. eureka or Prosagittodontus aff. eureka. Those specimens should be all assigned to Prosagittodontus cf. eureka.

Genus Serratocambria Müller and Hinz, 1991

Type species.—Serratocambria minuta Müller and Hinz, 1991.

Serratocambria minuta Müller and Hinz, 1991

Figure 25.3, 25.6, 25.7

1991 Serratocambria minuta Müller and Hinz, p. 38, pl. 27, figs. 1-17, text-fig. 15 (A, B).

1994 Serratocambria dacryoidea An and Mei, p. 538, pl. 2, figs. 25-26.

Description.-Ramiform elements, small and asymmetrical, with a long serrated lateral process. The small cusp is strongly recurved and spine-like. Both anterior and posterior sides are broadly rounded. The lateral process is long, compressed, and serrated on its upper edge. Basal cavity is moderate in size, with the apex extending nearly up to the point of flexure of the element. Cross section is round at the apex and changes into a variable outline at the base.

Materials._-12 specimens.

Occurrence.-Known only from the Wangcun section, where it occurs in the Westergaardodina cf. calix-Prooneotodus rotundatus Zone.

Remarks.-An and Mei (1994) erected a new species, Serratocambria dacryoidea. It differs from Serratocambria minuta in its short lateral process and the erect, serrated tiny denticles. The short lateral process is broken, and the shape of the denticles is considered to represent intraspecific variation. Thus, the two species are considered synonyms herein.

Genus Shandongodus An, 1982

Type species._-Shandongodus priscus An, 1982.

Shandongodus priscus An, 1982

Figure 26.37, 26.38 
1982 Shandongodus priscus An, p. 149, pl. 4, figs. 5-8, pl. 5, fig. 10.

1990 Shandongodus priscus An; Dong, pl. 1, figs. 10, 12, 13. 1993 Shandongodus priscus An; Dong, pl. 3, fig. 4.

1994 Shandongodus priscus An; An and Mei, pl. 2, figs. 17, 24.

2001a Shandongodus priscus An; Dong and Bergström, p. 972, pl. 3, fig. 14 .

2008 Shandongodus priscus An; Bagnoli et al., p. 112, fig. $3(\mathrm{~F}, \mathrm{G})$.

Materials._Eight specimens.

Occurrence.-Known from Paibi and Wangcun sections, where it occurs in the Shandongodus priscus-Hunanognathus tricuspidatus Zone.

Remarks.-The specimens at hand agree in all respects with those described and illustrated by An (1982).

Genus Wangcunognathus new genus

Type species.-Wangcunognathus elegans n. gen. n. sp.

Diagnosis.-Reclined coniform elements, with a short, adenticulate, posterior process which possesses a sharp oral costa with a conspicuous indentation. Anterior side of elements possess two sharp antero-lateral costae extending from apex to base. Posterior side of cusp possesses a sharp costa. Basal cavity deep, with a tip that ends higher than the top of posterior process.

Etymology.-Named for the Wangcun section in Hunan Province and gnathus, Greek, jaw.

Wangcunognathus elegans new genus new species

Figure 34.1-34.26

Diagnosis._As for the genus.

Description.--Reclined coniform elements with a short adenticulate, posterior process. It is asymmetrical due to lateral bending. The anterior sides of elements are slightly convex with two sharp anterolateral costae extending from apex to base. The posterior sides of cusps possess a sharp costa, which leads to the subtriangular cross-section of the cusp. The base is slightly either compressed or expanded laterally to a variable extent, so the cross-section of the base is variable in shape. The oral margin is characterized by a sharp costa with a conspicuous indentation. Basal cavity deep, with a tip that ends above the top of the posterior process.

Etymology._elegans, Latin, elegant.

Types.-Holotype: GMPKU2950 from the Westergaardodina lui-Westergaardodina ani Zone, Bitiao Formation, Wangcun section, Wangcun village, Yongshun county, Hunan Province.

Materials._-300 specimens.
Occurrence.-Known from the Wangcun section, where it occurs in the Westergaardodina lui-Westergaardodina ani Zone.

Remarks.-Wangcunognathus elegans n. gen. n. sp. probably is a paraconodont.

Genus Westergaardodina Müller, 1959

Type species.—Westergaardodina bicuspidata Müller, 1959.

Remarks.-The morphology of Westergaardodina is so different from that of other conodonts that some completely different morphological terms are used to describe these species. For example, there are two groups of species of Westergaardodina, those with two cusp-like features (bicuspidate) and those with three (tricuspidate). These cusp-like features are referred to as projections, two of which are lateral projections and the third (if present) is a median projection. The lateral projections may have a basal cavity or not. There may be a depression or groove around part or all of the outer perimeter of the lateral projections, referred to as a lateral cavity. In some species the projections are directed upward from the lower part of the element but then bend outward in the upper part; the turning point is where the bending begins. The morphology of elements described herein is based on the terms introduced or modified by Müller and Hinz (1991, p. 14-15).

Westergaardodina ahlbergi Müller and Hinz, 1991

Figure 35.3

? 1973 Westergaardodina muelleri (Nogami); Müller, p. 48, pl. 2, fig. 9 .

1982 Westergaardodina cf. muelleri (Nogami); An, p. 153, pl. 6, fig. 11.

1991 Westergaardodina ahlbergi Müller and Hinz, p. 41, pl. 38, figs. 1-11.

Materials.-Four specimens.

Occurrence.-Known from the Wangcun section, where it occurs in the Westergaardodina lui-Westergaardodina ani Zone.

Remarks.-The specimens at hand agree in all aspects with the species described and figured by Müller and Hinz (1991).

Westergaardodina ani Dong, Repetski, and Bergström, 2004c Figure 35.2, 35.4-35.6

2004c Westergaardodina ani Dong, Repetski, and Bergström, p. 1197, pl. 3, figs. 11-13, 16, 21.

Description.-Small, bicuspidate Westergaardodina. The anterior side is convex and characterized by deeply incised turning points, which may be indistinct due to the tiny, spinelike median projection. The median projection is absent in larger specimens. The posterior side is deeply concave. The two lateral projections are nearly of the same length, and the interspace between them is generally extremely narrow. The length/ width ratio is nearly three to one. The gross morphology of the unit looks like a slender spoon. Lateral cavities are absent or indistinctly developed along the upper four-fifths of the 


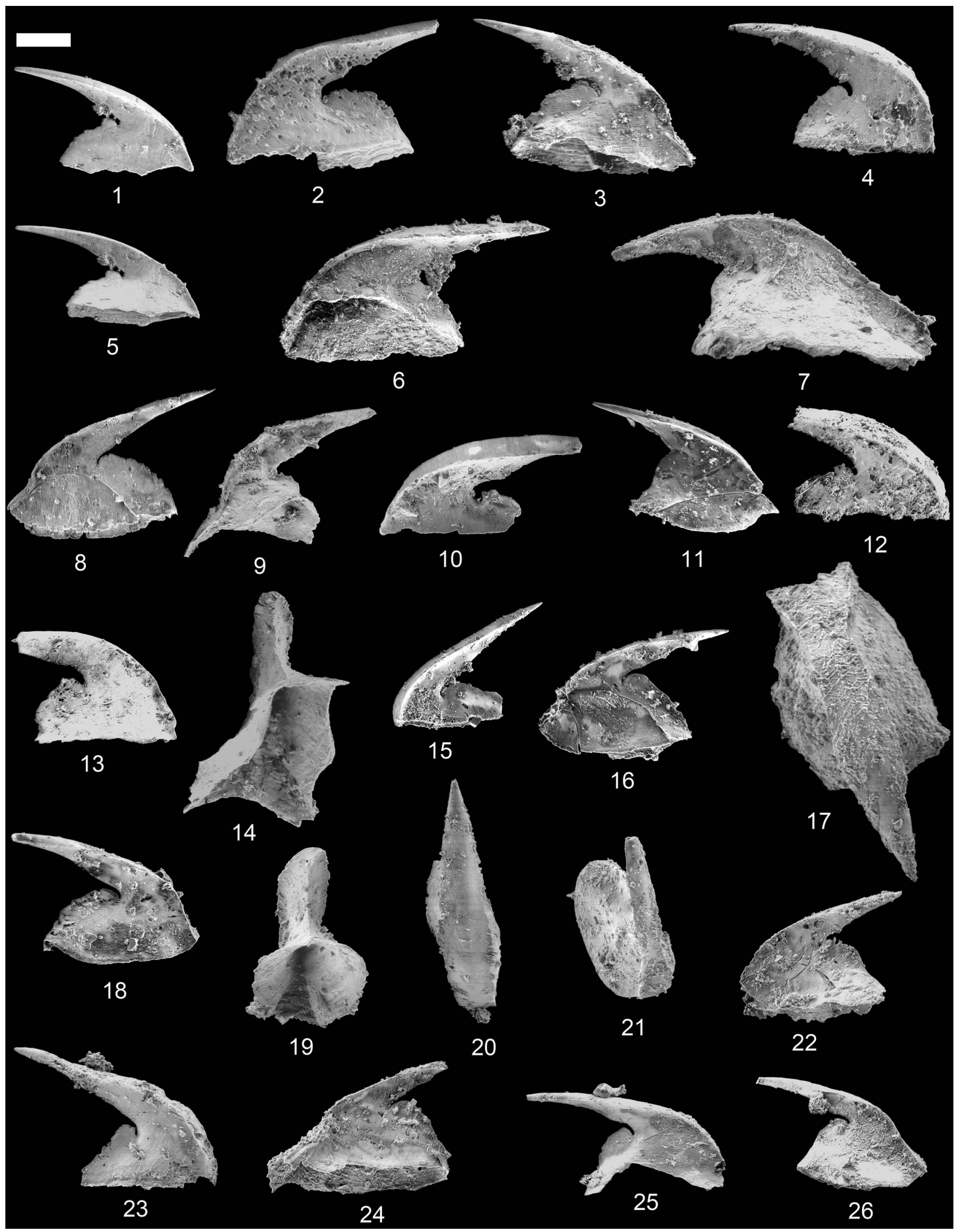


lateral projection. A basal cavity is absent, but a shallow furrow can be observed in some specimens.

Materials.—86 specimens.

Occurrence.-Known from Wangcun and Wa'ergang sections, where it ranges from the Westergaardodina luiWestergaardodina ani Zone through the Cordylodus lindstromi Zone (lower part).

Comparison.-The present species differs from Westergaardodina ligula in its slender appearance and the different lateral cavities. Moreover, it appears considerably lower stratigraphically than $W$. ligula.

Remarks.-The present species Westergaardodina ani was previously called Westergaardodina proligula, which is a nomen nudum (Dong, 1999, 2000).

Westergaardodina cf. behrae Müller and Hinz, 1991 Figure 35.9

1991 cf. Westergaardodina behrae Müller and Hinz, p. 42, pl. 37, figs. 1-6, 9, 10, 12, 13.

Materials.—12 specimens.

Occurrence.-Known from the Wangcun section, where it occurs in the Westergaardodina quadrata Zone.

Remarks.-The specimens at hand agree in gross morphology with Westergaardodina behrae but differ in its much larger size and the converging, shorter lateral projections.

\section{Westergaardodina brevidens Dong, 1993}

Figure 35.7, 35.8

1993 Westergaardodina brevidens Dong, p. 353, pl. 1, figs. 6, 7.

2001a Westergaardodina brevidens Dong; Dong and Bergström, p. 973, pl. 1, fig. 8, pl. 2, fig. 8, pl. 6, fig 6.

Materials.—28 specimens.

Occurrence.-Known from Paibi and Wangcun sections, where it ranges from the Gapparodus bisulcatus-Westergaardodina brevidens Zone through the Shandongodus priscus-Hunanognathus tricuspidatus Zone.

Remarks.-The present specimens agree well with those described and figured by Dong and Bergström (2001a).

Westergaardodina cf. calix Müller and Hinz, 1991 Figure 35.10-35.20

1991 cf. Westergaardodina cf. calix Müller and Hinz, p. 43, pl. 37, figs. 7, 8, 11, 14-16.

2004c Westergaardodina cf. calix Müller and Hinz; Dong et al., p. 1197, pl. 1, figs. 15-20, 22-25, 28.

Description.-Small- to medium-size, bilaterally symmetrical, tricuspidate elements. The profile is rather flat. The median projection is narrower and longer than the lateral ones. In relation to the total length, the turning points are fairly high. The anterior side is smooth, with a wide central depression. The posterior side is a little smaller than the anterior one, especially along the lateral margin. The median projection bears a distinct rod-like keel, which extends above the turning points but does not reach the basal margin. Lateral cavities are developed in most specimens along the upper part of the lateral projections. Basal cavity is absent.

Materials._78 specimens.

Occurrence.-Known from the Wangcun and Wa'ergang sections, where it ranges from the Westergaardodina cf. calix-Prooneotodus rotundatus Zone through the Cordylodus intermedius Zone.

Remarks.-This species includes specimens which are not well preserved and previously were included in Westergaardodina cf. behrae. The present form resembles Westergaardodina calix in gross morphology, but it differs in its narrower and longer median projection, and in being thicker. Moreover, it appears lower stratigraphically than W. calix. Because the majority of the specimens of Westergaardodina cf. calix are not completely preserved in that one, two, or three of the upper parts of the three projections are missing, we do not propose it as a new species. The main difference between Westergaardodina behrae and $W$. cf. calix is in the height of the turning points, the width of the median projection, and the relative lengths of the elements (Müller and Hinz, 1991, p. 42).

Westergaardodina dimorpha new species Figures 35.22-35.26, 36.1-36.4

Figure 34. (1-26) Wangcunognathus elegans n. gen. n. sp.; (1) Bitiao Formation, Wangcun section, GMPKU2941, lateral view; (2) Bitiao Formation, Wangcun section, GMPKU2942, lateral view; (3) Bitiao Formation, Wangcun section, GMPKU2943, lateral view; (4) Bitiao Formation, Wangcun section, GMPKU2944, lateral view; (5) Bitiao Formation, Wangcun section, GMPKU2945, lateral view; (6) Bitiao Formation, Wangcun section, GMPKU2946, lateral view; (7) Bitiao Formation, Wangcun section, GMPKU2947, lateral view; (8) Bitiao Formation, Wangcun section, GMPKU2948, lateral view; (9) Bitiao Formation, Wangcun section, GMPKU2949, lateral view; (10) Bitiao Formation, Wangcun section, holotype, GMPKU2950, lateral view; (11) Bitiao Formation, Wangcun section, GMPKU2951, lateral view; (12) Bitiao Formation, Wangcun section, GMPKU2952, lateral view; (13) Bitiao Formation, Wangcun section, GMPKU2953, lateral view; (14) Bitiao Formation, Wangcun section, GMPKU2954, posterior view; (15) Bitiao Formation, Wangcun section, GMPKU2955, lateral view; (16) Bitiao Formation, Wangcun section, GMPKU2956, lateral view; (17) Bitiao Formation, Wangcun section, GMPKU2957, oblique anterior view; (18) Bitiao Formation, Wangcun section, GMPKU2958, lateral view; (19) Bitiao Formation, Wangcun section, GMPKU2959, posterior view; (20) Bitiao Formation, Wangcun section, GMPKU2960, oblique anterior view; (21) Bitiao Formation, Wangcun section, GMPKU2961, lateral-anterior view; (22) Bitiao Formation, Wangcun section, GMPKU2962, lateral view; (23) Bitiao Formation, Wangcun section, GMPKU2963, lateral view; (24) Bitiao Formation, Wangcun section, GMPKU2964, lateral view; (25) Bitiao Formation, Wangcun section, GMPKU2965, lateral view; (26) Bitiao Formation, Wangcun section, GMPKU2966, lateral view. Scale bar represents $127 \mu \mathrm{m}$ (1-26). 


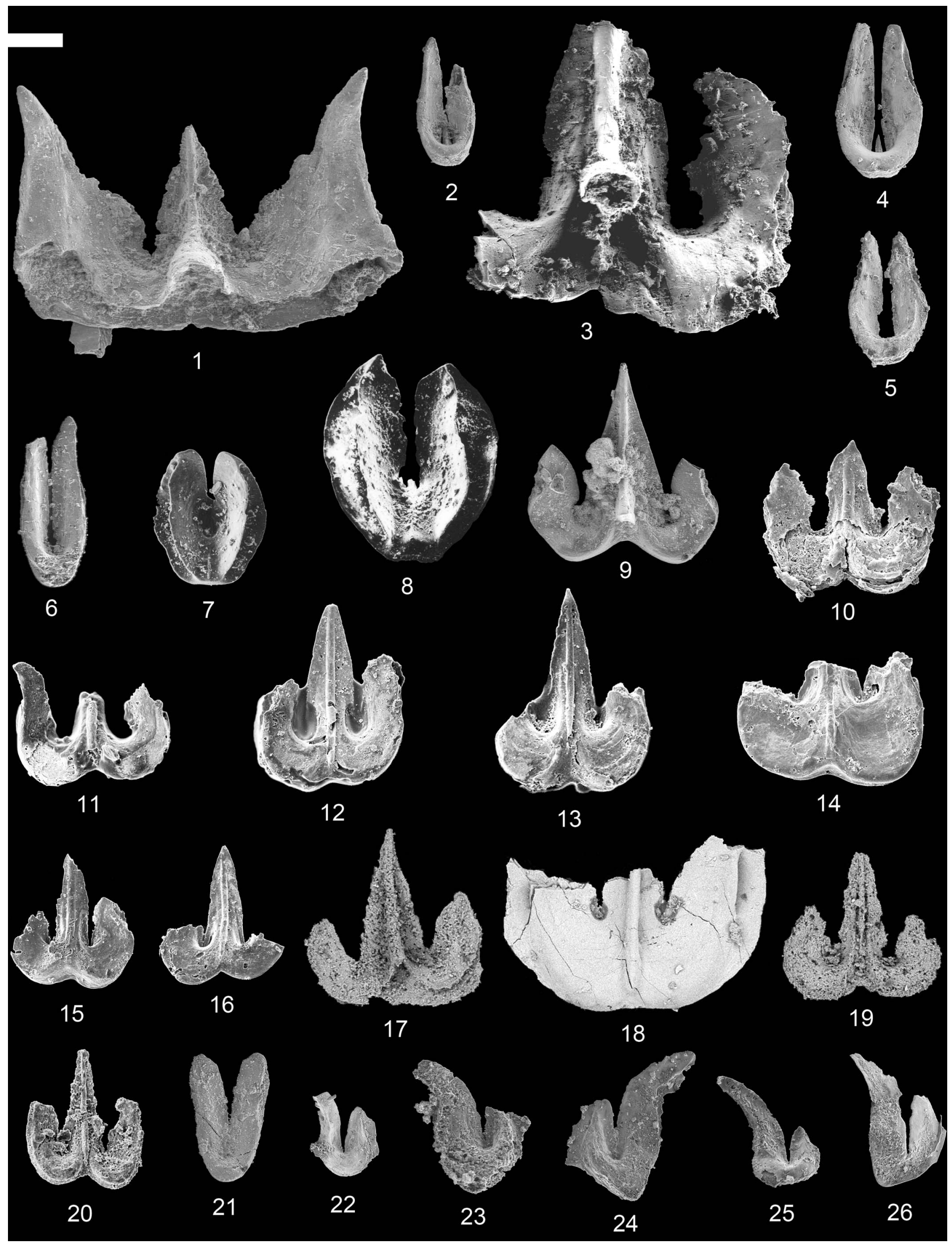


Diagnosis.-Small, asymmetrical, bicuspidate elements comprising left and right forms. One projection is much longer than the other. No basal cavity. The lateral cavities are very small or there are no lateral cavities.

Description.-Small-sized, asymmetrical, bicuspidate elements comprising left and right forms. The lateral projections are not of equal size; one is much longer than the other. They are subcircular in the lower part of elements and diverge at a very small angle at first, but the angle increases upward and the projections are recurved outward. The anterior side is flat or a little convex, whereas the posterior side is concave. Both projections are fused up to a level that is much higher than the turning points or are fused up to the tips of the projections, so there are no basal cavities. The very small lateral cavities are restricted only to the upper parts of the projections or there are no lateral cavities. A broad bulge may be developed in the basal region. Sometimes, the longer projection is broken and the recurved upper part is not preserved. Left and right forms occur in about equal numbers.

Etymology.—dimorpha, Latin, dimorphic.

Types.-Holotype: GMPKU2980 from the Westergaardodina lui-Westergaardodina ani Zone, Bitiao Formation, Wangcun section, Wangcun village, Yongshun county, Hunan Province.

Materials._-200 specimens

Occurrence.-Known from the Wangcun section, where it occurs in the Westergaardodina lui-Westergaardodina ani Zone.

Westergaardodina elegans Dong and Bergström, 2001a Figure 36.5-36.9, 36.13

1993 Westergaardodina sp. A. Dong, p. 355, pl. 2, figs. 1-4. 2001a Westergaardodina elegans Dong and Bergström, p. 973 , pl. 3, fig. 18, pl. 4, figs. 9, 15, pl. 6, fig. 7 .

2006 Westergaardodina elegans Dong and Bergström; Qi et al., p. 187, pl. 3, figs. 5, 7.

Materials._-266 specimens.
Occurrence.-Known from Paibi and Wangcun sections, where it ranges from the Shandongodus priscus-Hunanognathus tricuspidatus Zone through the Westergaardodina luiWestergaardodina ani Zone.

Remarks.-The present specimens agree well with those described and figured by Dong and Bergström (2001a).

\section{Westergaardodina gigantea new species}

Figure 36.10-36.12

Diagnosis.-Large, symmetrical, bicuspidate elements. The posterior side is much smaller than the anterior side. The turning point is located very high.

Description.-Large-sized, symmetrical, bicuspidate elements. The anterior side is convex, whereas the posterior side is concave. The posterior side is much smaller than the anterior side. Both projections are fused at the bases. The turning points are located very high. The lateral projections are of equal size. Tips of projections are directed slightly outward, beginning near the tops of the projections. The large lateral openings wrap around the base and are exposed on the anterior sides of the base.

Etymology.—gigantea, Latin, gigantic.

Types.-Holotype: GMPKU2994 from the Westergaardodina matsushitai-Westergaardodina grandidens Zone, Chefu Formation, Wangcun section, Wangcun village, Yongshun county, Hunan Province.

Materials.-12 specimens.

Occurrence.-Known only from Wangcun section, where it occurs in the Westergaardodina matsushitai-Westergaardodina grandidens Zone.

Remarks.-Westergaardodina gigantea $\mathrm{n}$. sp. is distinguished by its large size and by the turning points being located very high.

Westergaardodina grandidens Dong, 1993 Figure 36.14-36.17

Figure 35. (1) Westergaardodina sp. C, Shenjiawan Formation, Wa'ergang section, GMPKU2967, posterior view; (2, 4-6) Westergaardodina ani Dong, Repetski and Bergström, 2004c; (2) Bitiao Formation, Wangcun section, GMPKU2968, posterior view; (4) Bitiao Formation, Wangcun section, GMPKU2969, posterior view; (5) Bitiao Formation, Wangcun section, GMPKU2970, posterior view; (6) Panjiazui Formation, Wa'ergang section, GMPKU2971, posterior view; (3) Westergaardodina ahlbergi Müller and Hinz, 1991, Bitiao Formation, Wangcun section, GMPKU2972, posterior view; (7, 8) Westergaardodina brevidens Dong, 1993; (7) Huaqiao Formation, Paibi section, GMPKU2973, posterior view; (8) Huaqiao Formation, Paibi section, GMPKU2974, posterior view; (9) Westergaardodina cf. behrae Müller and Hinz, 1991, Bitiao Formation, Wangcun section, GMPKU2975, posterior view; (10-20) Westergaardodina cf. calix Müller and Hinz, 1991; (10) Bitiao Formation, Wangcun section, GMPKU2136, posterior view; (11) Bitiao Formation, Wangcun section, GMPKU2135, posterior view; (12) Bitiao Formation, Wangcun section, GMPKU2137, posterior view; (13) Bitiao Formation, Wangcun section, GMPKU2130, posterior view; (14) Bitiao Formation, Wangcun section, GMPKU2134, posterior view; (15) Bitiao Formation, Wangcun section, GMPKU2128, posterior view; (16) Bitiao Formation, Wangcun section, GMPKU2127, posterior view; (17) Bitiao Formation, Wangcun section, GMPKU2129, posterior view; (18) Shenjiawan Formation, Wa'ergang section, GMPKU2133, posterior view; (19) Bitiao Formation, Wangcun section, GMPKU2131, posterior view; (20) Bitiao Formation, Wangcun section, GMPKU2132, posterior view; (21) Westergaardodina sp. D, Huaqiao Formation, Wangcun section, GMPKU2976, posterior view; (22-26) Westergaardodina dimorpha n. sp.; (22) Bitiao Formation, Wangcun section, GMPKU2977, posterior view; (23) Bitiao Formation, Wangcun section, GMPKU2978, posterior view; (24) Bitiao Formation, Wangcun section, GMPKU2979, posterior view; (25) Bitiao Formation, Wangcun section, holotype, GMPKU2980, posterior view; (26) Bitiao Formation, Wangcun section, GMPKU2981, anterior view. Relative scale bar represents $171 \mu \mathrm{m}(\mathbf{1}, \mathbf{3}, \mathbf{6}, \mathbf{2 5}, \mathbf{2 6}), 165 \mu \mathrm{m}(\mathbf{2}, \mathbf{4}, \mathbf{5}, \mathbf{8}-\mathbf{1 3}, \mathbf{1 5}, \mathbf{1 8}, \mathbf{2 0}, \mathbf{2 1}, \mathbf{2 3}, \mathbf{2 4}), 156 \mu \mathrm{m}(\mathbf{7}, \mathbf{1 4}, \mathbf{1 6}, \mathbf{1 7}, \mathbf{1 9}), 264 \mu \mathrm{m}(\mathbf{2 2})$. 

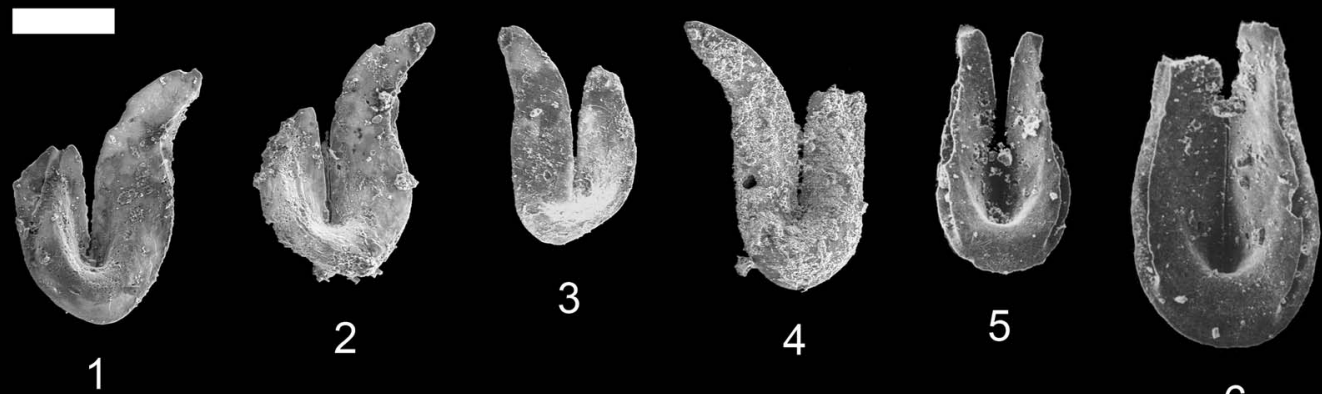

6
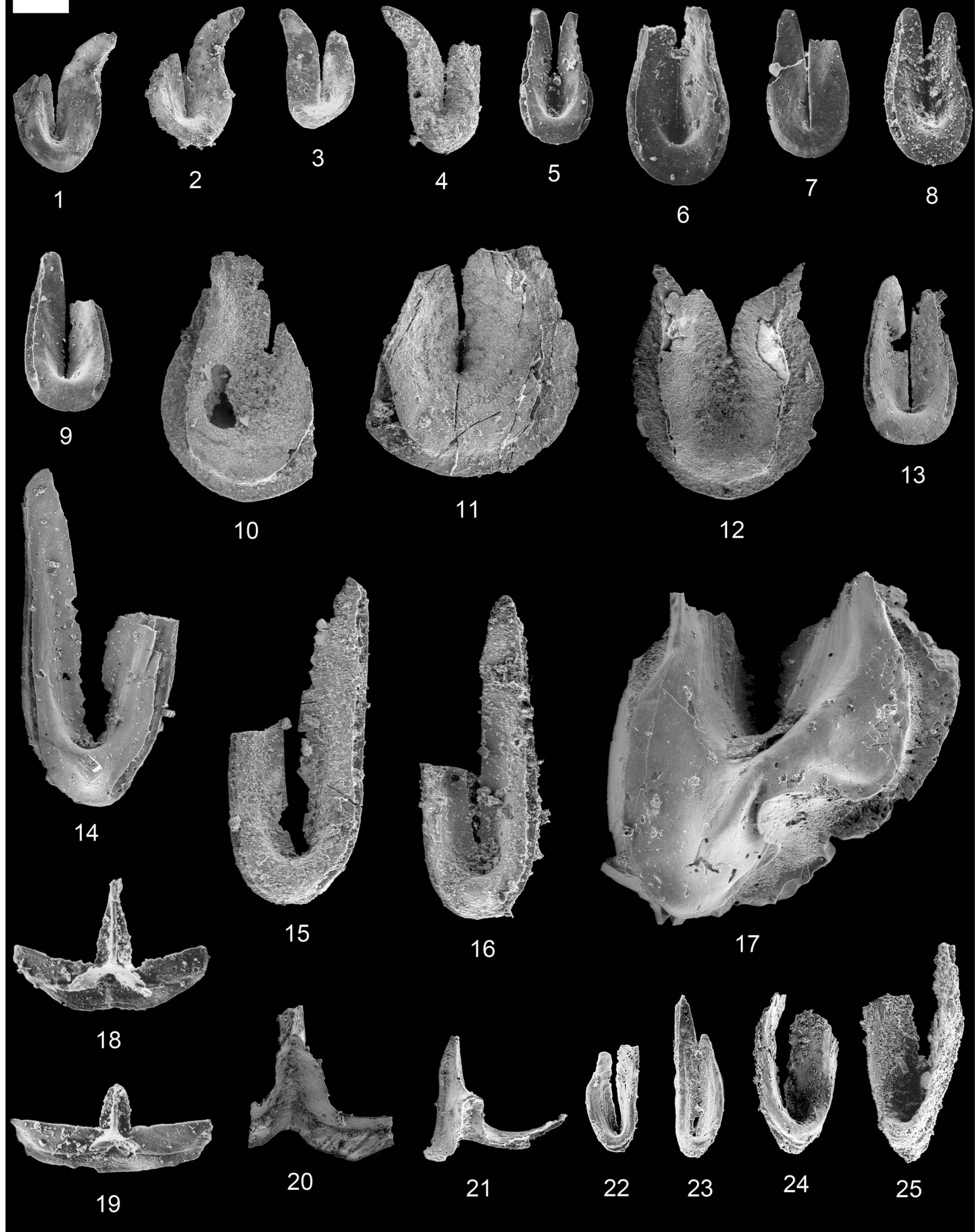
1978 Westergaardodina moessebergensis (Müller); Abaimova, p. 503, pl. 8, figs. 8, 10, ?11.

1991 Westergaardodina matsushita (Nogami); Müller and Hinz, pl. 28, fig. 17 only (not figs. 15-16, 18-20). (part)

1993 Westergaardodina grandidens Dong, p. 354, pl. 3, figs. 5, 8, 9 .

2001a Westergaardodina grandidens Dong; Dong and Bergström, p. 973, pl. 4, figs. 1, 5, 7.

2013 Westergaardodina grandidens Dong; Lee, p. 169, pl. 2, figs. 10, 23-27.

Materials.-66 specimens.

Occurrence.--known from the Paibi and Wangcun sections, where it occurs in the Westergaardodina matsushitai-Westergaardodina grandidens Zone.

Remarks.-The present specimens agree well with those described and figured by Dong and Bergström (2001a).

Westergaardodina horizontalis Dong, 1993

Figure 36.18, 36.19

1993 Westergaardodina horizontalis Dong, p. 354, pl. 1, figs. 13-14.

2001a Westergaardodina horizontalis Dong; Dong and Bergström, p. 974, pl. 6, figs. 13-14.

? 2008 Westergaardodina horizontalis Dong; Bagnoli et al., p. 112 , fig. 3 (M).

Materials._-12 specimens.

Occurrence.-Known from the Paibi and Wangcun sections, where it occurs in the Gapparodus bisulcatus-Westergaardodina brevidens Zone.

Remarks.-The present specimens agree well with those described and figured by Dong and Bergström (2001a).

Westergaardodina cf. horizontalis Dong, 1993

Figure 36.20, 36.21 cf. 1993 Westergaardodina horizontalis Dong, p. 354, pl. 1, figs. 13-14.

2001a Westergaardodina cf. horizontalis Dong; Dong and Bergström, p. 976, pl. 2, fig. 21.

Materials.-Six specimens.

Occurrence.-Known from the Wangcun secton, where it occurs in the Westergaardodina matsushitai-Westergaardodina grandidens Zone.

Remarks.-This form is similar to Westergaardodina horizontalis in having two horizontally extending, wing-like lateral projections, but the keel on the median projection is much shorter than in $W$. horizontalis s. s., and it is solid rather than hollow. The keel extends from the tip to a point approximately one-third of the length of the median projection, where the posterior side of the element is nearly perpendicular to the flat anterior side, forming deep and broad basal and lateral cavities.

Westergaardodina lui Dong, Repetski, and Bergström, 2004c Figures 36.22-36.25, 37.1-37.3, 37.7-37.9

2004c Westergaardodina lui Dong, Repetski, and Bergström, p. 1197, pl. 3. figs. 4-10, 18-20, 22-24, 27.

Description.-A small, bilaterally asymmetrical bicuspidate Westergaardodina. One lateral projection is longer than another, and there are right and left forms. The anterior side is strongly convex and is characterized by a deeply incised turning point. The posterior side is deeply concave, with the maximum depth at the turning point. Along the longer lateral projection, the posterior side is smaller than the anterior one, resulting in a shallow lateral cavity extending along most of the projection. The lateral cavity is missing or weakly developed within the upper one-third of the shorter lateral projection. The base is rather narrow.

Materials._98 specimens.

Occurrence.-Known from the Wangcun and Wa'ergang sections, where it ranges from the Westergaardodina lui-Westergaardodina ani Zone through the Cordylodus intermedius Zone.

Figure 36. (1-4) Westergaardodina dimorpha n. sp.; (1) Bitiao Formation, Wangcun section, GMPKU2982, posterior view; (2) Bitiao Formation, Wangcun section, GMPKU2983, posterior view; (3) Bitiao Formation, Wangcun section, GMPKU2984, anterior view; (4) Bitiao Formation, Wangcun section, GMPKU2985, posterior view; (5-9, 13) Westergaardodina elegans Dong and Bergström, 2001a; (5) Chefu Formation, Paibi section, GMPKU2986, posterior view; (6) Chefu Formation, Paibi section, GMPKU2987, posterior view; (7) Chefu Formation, Paibi section, GMPKU2988, anterior view; (8) Chefu Formation, Paibi section, GMPKU2989, posterior view; (9) Chefu Formation, Paibi section, GMPKU2990, posterior view; (13) Chefu Formation, Paibi section, GMPKU2991, posterior view; (10-12) Westergaardodina gigantea n. sp.; (10) Chefu Formation, Wangcun section, GMPKU2992, posterior view; (11) Chefu Formation, Wangcun section, GMPKU2993, posterior view; (12) Chefu Formation, Wangcun section, holotype, GMPKU2994, posterior view; (14-17) Westergaardodina grandidens Dong, 1993; (14) Chefu Formation, Paibi section, GMPKU2995, posterior view; (15) Chefu Formation, Wangcun section, GMPKU2996, posterior view; (16) Chefu Formation, Wangcun section, GMPKU2997, posterior view; (17) Chefu Formation, Paibi section, large broken basal part, GMPKU2998, posterior view; (18, 19) Westergaardodina horizontalis Dong, 1993; (18) Huaqiao Formation, Paibi section, GMPKU2999, posterior view; (19) Huaqiao Formation, Paibi section, GMPKU3000, posterior view; $(\mathbf{2 0}, \mathbf{2 1})$ Westergaardodina cf. horizontalis Dong, 1993; (20) Chefu Formation, Wangcun section, GMPKU3001, oblique posterior view; (21) Chefu Formation, Wangcun section, GMPKU3002, oblique posterior view; (22-25) Westergaardodina lui Dong, Repetski and Bergström, 2004c; (22) Bitiao Formation, Wangcun section, GMPKU2182, posterior view; (23) Bitiao Formation, Wangcun section, GMPKU2183, posterior view; (24) Shenjiawan Formation, Wangcun section, GMPKU3003, posterior view; (25) Shenjiawan Formation, Wangcun section, GMPKU3004, posterior view. Relative scale bar represents $156 \mu \mathrm{m}(\mathbf{1}, \mathbf{2}, \mathbf{4}, \mathbf{7}, \mathbf{1 3}-\mathbf{1 7}, \mathbf{1 9}, \mathbf{2 0}, \mathbf{2 4}, \mathbf{2 5}), 145 \mu \mathrm{m}(\mathbf{3 , 5}, \mathbf{9}, \mathbf{1 8}, \mathbf{2 2}, \mathbf{2 3})$ $136 \mu \mathrm{m}(\mathbf{6}, \mathbf{8}), 218 \mu \mathrm{m}(\mathbf{1 0 - 1 2}), 199 \mu \mathrm{m}(\mathbf{2 1})$. 
Comparison.- - The present species differs from Westergaardodina ligula in its narrow base and asymmetrical bicuspidate elements. It differs from Westergaardodina wimani in its narrow base, strongly convex anterior side, and deeply concave posterior side. Also, the lateral projections of $W$. wimani differ considerably in length.

\section{Westergaardodina matsushitai Nogami, 1966}

Figure 37.4-37.6, 37.10-37.12

1966 Westergaardodina matsushitai Nogami, p. 360, pl. 10, figs. 6-8.

1971 Westergaardodina matsushitai Nogami; Müller, fig. 1d.

1978 Westergaardodina matsushitai Nogami; Abaimova, p. 502, pl. 8, fig. 6 .

1981 Westergaardodina matsushitai Nogami; An, p. 219, pl. 1, fig. 4.

1982 Westergaardodina matsushitai Nogami; An, p. 153, pl. 6, figs. 1-4.

1983 Westergaardodina matsushitai Nogami; An et al., p. 163 , pl. 1, figs. 3, 4, 8 .

1991 Westergaardodina matsushitai Nogami; Müller and Hinz, p. 46, pl. 28, figs. 15, 16, 18-20 (not fig. 17). (part)

1993 Westergaardodina matsushitai Nogami; Dong, p. 354, pl. 1, figs. 4, 5.

2001a Westergaardodina matsushitai Nogami; Dong and Bergström, p. 976, pl. 6, figs. 10-12.

? 2002a Westergaardodina matsushitai Nogami; Lee, p. 164, pl. 1, fig. 1.

? 2002b Westergaardodina matsushitai Nogami; Lee, p. 25, pl. 1, fig. 3.

2006 Westergaardodina matsushitai Nogami; Qi et al., p. 187 , pl. 3 , fig. 4 .

Materials. -47 specimens.

Occurrence.-Known from the Paibi and Wangcun sections, where it occurs in the Westergaardodirna matsushitaiWestergaardodirna grandidens Zone.

Remarks.-The specimens at hand agree well with those described and illustrated by Nogami (1966) and Müller and Hinz (1991), except that their plate 8, figure 7 is assigned herein to Westergaardodina grandidens. Some specimens exhibit a smaller than typical angle of divergence between the lateral projections, but that is considered to represent intraspecific variation. Müller and Hinz's (1998, p. 105) experimented on elements of Westergaardidina polymorpha and concluded that the angle of divergence is not of taxonomic value. However, that is not known whether or not this conclusion can be applied to other species of Westergaardodina.

Westergaardodina microdentata Zhang in An et al., 1983 Figure 37.13, 37.14, 37.16

1983 Westergaardodina microdentata Zhang in An et al., p. 164, pl. 1, figs. 15-17; text-fig. 9 (7).

1991 Westergaardodina microdentata Zhang; Müller and Hinz, p. 47, pl. 40, figs. 8-15.

Materials._-Nine specimens.

Occurrence.-Known from the Wangcun section, where it occurs from the Westergaardodina lui-Westergaardodina ani Zone through the Westergaardodina cf. calix-Prooneotodus rotundatus Zone.

Remarks.-The present specimens agree in all aspects with the previous descriptions and illustrations of Westergaardodina microdentata.

Westergaardodina cf. nogamii Müller and Hinz, 1991

Figure 37.15

cf. 1991 Westergaardodina nogamii Müller and Hinz, p. 47, pl. 39, figs. 1-10.

Materials.-Only one specimen.

Occurrence.-Known from the Wa'ergang section, where it occurs in the Eoconodontus Zone.

Remarks. - The specimen at hand approximately agrees in gross morphology with Westergaardodina nogamii, but it differs in its much smaller size, diverging lateral projections, and shorter median projection. Nevertheless, the present specimen is insufficient to name a new species.

Westergaardodina quadrata (An, 1982)

Figure 37.18-37.26

\footnotetext{
Figure 37. (1-3, 7-9) Westergaardodina lui Dong, Repetski, and Bergström, 2004c; (1) Bitiao Formation, Wangcun section, GMPKU3005, posterior view; (2) Bitiao Formation, Wangcun section, GMPKU3006, posterior view; (3) Bitiao Formation, Wangcun section, GMPKU3007, anterior view; (7) Bitiao Formation, Wangcun section, GMPKU3008, posterior view; (8) Bitiao Formation, Wangcun section, GMPKU3009, posterior view; (9) Bitiao Formation, Wangcun section, GMPKU3010, posterior view; (4-6, 10-12) Westergaardodina matsushitai Nogami, 1966; (4) Chefu Formation, Wangcun section, GMPKU3011, posterior view; (5) Chefu Formation, Wangcun section, GMPKU3012, posterior view; (6) Chefu Formation, Wangcun section, GMPKU3013, posterior view; (10) Chefu Formation, Wangcun section, GMPKU3014, posterior view; (11) Chefu Formation, Wangcun section, GMPKU3015, posterior view; (12) Bitiao Formation, Wangcun section, GMPKU3016, posterior view; (13) (14, 16) Westergaardodina microdentata Zhang, 1983; (13) Bitiao Formation, Wangcun section, GMPKU3017, posterior view; (14) Bitiao Formation, Wangcun section, GMPKU3018, posterior view; (16) Bitiao Formation, Wangcun section, GMPKU3019, posterior view; (15) Westergaardodina cf. nogamii Müller and Hinz, 1991, Shenjiawan Formation, Wa'ergang section, GMPKU3020, posterior view; (17) Westergaardodina sp. E, Bitiao Formation, Wangcun section, GMPKU3021, posterior view; (18-26) Westergaardodina quadrata (An, 1982); (18) Chefu Formation, Paibi section, GMPKU3022, posterior view; (19) Chefu Formation, Paibi section, GMPKU3023, posterior view; (20) Chefu Formation, Paibi section, GMPKU3024, posterior view; (21) Chefu Formation, Paibi section, GMPKU3025, posterior view; (22) Chefu Formation, Paibi section, GMPKU3026, posterior view; (23) Chefu Formation, Wangcun section, GMPKU3027, anterior view; (24) Chefu Formation, Wangcun section, GMPKU3028, posterior view; (25) Chefu Formation, Wangcun section, GMPKU3029, posterior view; (26) Chefu Formation, Wangcun section, GMPKU3030, posterior view. Relative scale bar represents $143 \mu \mathrm{m}(\mathbf{1 - 3}, \mathbf{5}, \mathbf{6}, \mathbf{9 - 1 7}, \mathbf{1 9}, \mathbf{2 3 - 2 6}), 136 \mu \mathrm{m}(\mathbf{4}, \mathbf{7}, \mathbf{8}, \mathbf{1 8}, \mathbf{2 0}, \mathbf{2 1}), 219 \mu \mathrm{m}(\mathbf{2 2})$.
} 


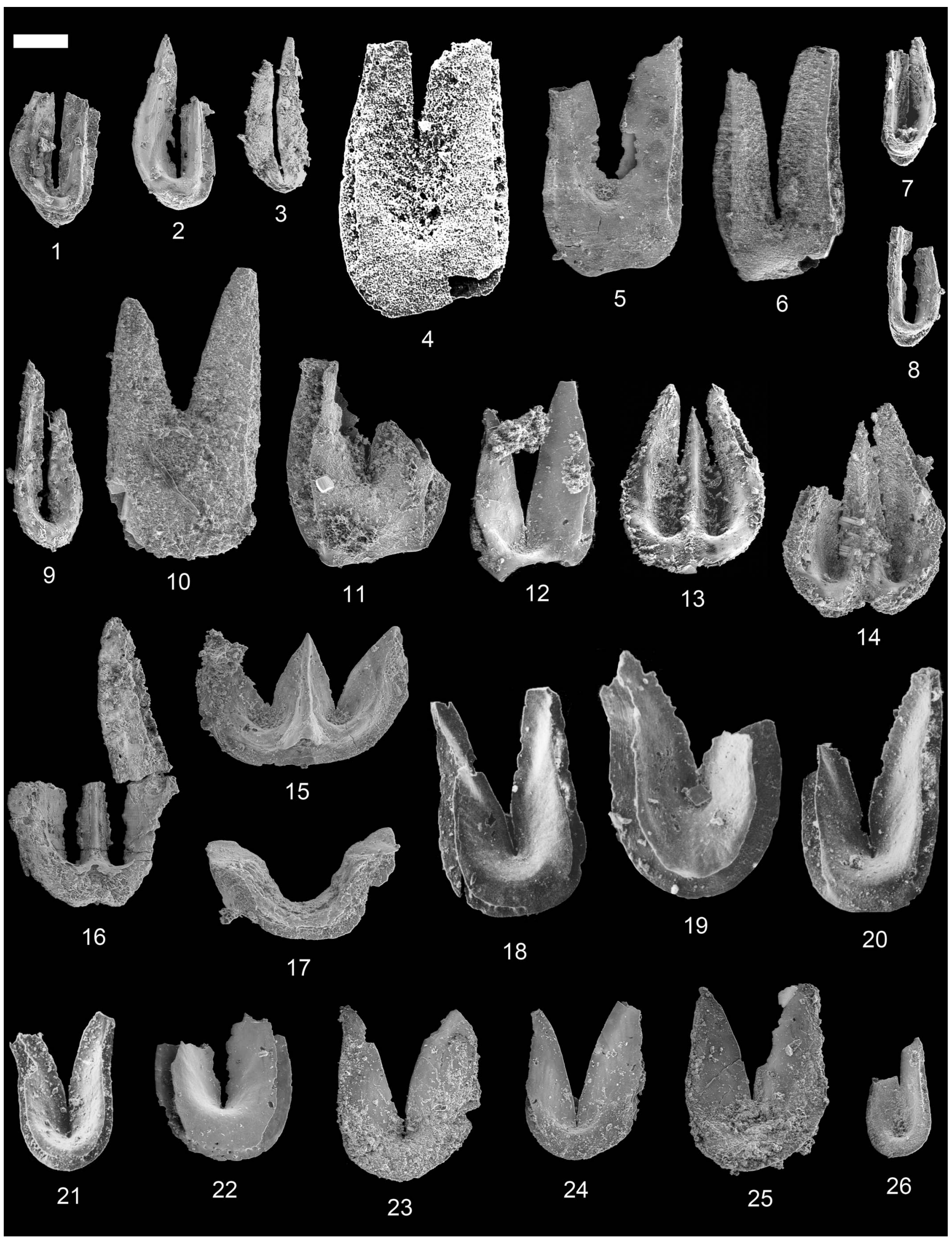


1982 Westergaardodina moessebergensis quadrata An, p. 153 , pl. 6, figs. 5-8, 10.

1983 Westergaardodina moessebergensis (An), An et al., p. 164, pl. 1, fig. 6 only.

1987 Westergaardodina bicuspidata (Müller); An, p. 115, pl. 3, figs. 13, 18.

1991 Westergaardodina quadrata (An); Müller and Hinz, p. 50, pl. 30, figs. 9, 11-21.

1993 Westergaardodina quadrata (An); Dong, pl. 2, figs. 6, $7,9,10,12$.

2001a Westergaardodina quadrata (An); Dong and Bergström, p. 978, pl. 1, fig. 14, pl. 3, fig. 15, pl. 6, figs. $4,8$.

2006 Westergaardodina quadrata (An); Qi et al., p. 187, pl. 3, fig. 1.

2009 Westergaardodina quadrata (An); Lee et al., p. 425, fig. 8 (19), p. 427, fig. 9 (16).

Materials._79 specimens.

Occurrence.-Known from the Paibi and Wangcun sections, where it ranges from the Westergaardodina quadrata Zone through the Westergaardodina matsushitai-Westergaardodina grandidens Zone.

Remarks.-The specimens at hand agree well with those described and illustrated by An (1982) and Müller and Hinz (1991).

Westergaardodina sola new species Figure 26.1-26.3

2001a Westergaardodina sp. Dong and Bergström, p. 967, pl. 2, fig. 18.

Diagnosis.-Medium-sized elements with unique outline. The posterior side is smaller than the anterior, with a prominent bulge on the posterior side. Both sides are fused along the upper margin, so that there is only one "projection." Basal cavity is large and connected with the "lateral cavity".

Description.-Element is medium-sized, with an outline that is unique among all known species of Westergaardodina. The anterior side is flat, whereas the posterior side is concave with a prominent bulge. The posterior side is smaller than the anterior. Both sides are fused along the upper margin, which is formed into a sharp costa. Both sides extend upward on the left part of the element, leading to the formation of a structure similar to a projection. Basal cavity is large and connected with the opening of the projection-like structure. The size of the posterior side and the length and shape of the "lateral projection" are variable.

Etymology.—sola, Latin, sole, referring to the unique outline of the element.

Types.-Holotype: GMPKU3033 from the Westergaardodina quadrata Zone, Chefu Formation, Paibi section, Paibi village, Huayuan county, Hunan Province.
Materials.-Nine specimens.

Occurrence.-Known from the Wangcun and Paibi sections, where it ranges from Westergaardodina quadrata Zone through the Westergaardodina matsushitai-Westergaardodina grandidens Zone.

\section{Westergaardodina tetragonia Dong, 1993}

Figure 26.4-26.9

1993 Westergaardodina tetragonia Dong, p. 355, pl. 1, figs. 1-3, 9 .

2001a Westergaardodina tetragonia Dong; Dong and Bergström, p. 979, pl. 6, figs. 1, 3.

non 2006 Westergaardodina tetragonia Dong; Qi et al., p. 187, pl. 3, fig. 6 .

Materials.—45 specimens.

Occurrence.-Known from the Paibi and Wangcun sections, where it ranges from the Shandongodus priscus-Hunanognathus tricuspidatus Zone through the Westergaardodina quadrata Zone.

Remarks.-The present specimens agree well with those described and figured by Dong and Bergström (2001a).

Westergaardodina tricuspidata Müller, 1959

Figure 26.10-26.24

1959 Westergaardodina tricuspidata Müller, p. 470, pl. 15, figs. 5, 6.

1965 Westergaardodina tricuspidata Müller; Grant, p. 145, pl. 15, fig. 31.

1979 Westergaardodina tricuspidata Müller; Bednarczyk, p. 436 , pl. 2 , fig. 5 .

1991 Westergaardodina tricuspidata Müller; Müller and Hinz, p. 50, pl. 36, figs. 1-4, 6.

Materials.—100 specimens.

Occurrence.-Known from the Wangcun and Wa'ergang sections, where it ranges from the Westergaardodina lui-Westergaardodina ani Zone through the Westergaardodina cf. calix-Prooneotodus rotundatus Zone.

Remarks.-The specimens at hand agree well with those described and illustrated by Müller (1959) and Müller and Hinz (1991).

Westergaardodina wimani Szaniawski, 1971

Figure 26.25

1971 Westergaardodina wimani Szaniawski, p. 409, pl. 1, fig. 5, pl. 5, figs. 7-9.

1982 Westergaardodina wimani Szaniawski; An, p. 156, pl. 9, fig. 9 only (not fig. 14). (part)

1991 Westergaardodina wimani Szaniawski; Müller and Hinz, p. 51, pl. 28, figs. 21-27.

2004c Westergaardodina wimani Szaniawski; Dong et al., p. 1205, pl. 3, fig. 29. 
Materials.—Eight specimens.

Occurrence.-Known from the Wangcun section, where it ranges from the Westergaardodina cf. calix-Prooneotodus rotundatus Zone through the Proconodontus Zone.

Remarks.-The present specimens agree well with those described and illustrated by Szaniawski (1971) and Müller and Hinz (1991). Müller and Hinz (1991) assigned Westergaardodina semitricuspidata An, 1982 to Westergaardodina wimani. However, An (1982) erected his species based on only two broken specimens. In the light of additional similar specimens recovered from Hunan, the characters of this species are much more evident.

\section{Westergaardodina sp. A}

Figure 26.26

Description.-Large-sized, symmetrical, bicuspidate element. The turning point is located very high. The anterior side is flat, whereas the posterior side is slightly concave. The lateral projections extend from the triangular lower part of the element and diverge greatly, leading to an anchor-shaped profile of the element. Large lateral cavities extend from tips to bases of projections and connect with the basal cavity.

Materials.—Only one specimen.

Occurrence.-Known from Wangcun section, where it occurs in the Westergaardodina cf. calix-Prooneotodus rotundatus Zone.

Remarks.—Westergaardodina sp. A is distinguished by its large size, very high turning point, and the anchor-shaped profile. Nevertheless, the present specimen is inadequate to name a new species.

\section{Westergaardodina sp. B}

Figure 26.27

Description.-Large-sized, symmetrical, bicuspidate element. The turning point is located relatively high. The anterior side is slightly convex, whereas the posterior side is concave. Both lateral projections are fused up to a level that is above the turning point. The lateral projections extend from the semicircular lower part of element and diverge slightly. Tips of projections directed slightly outward, and lateral openings are only in the upper parts of the projections. The lower part of element is very thick antero-posteriorly.

Materials.—Only one specimen.

Occurrence.-Known from the Wa'ergang sections, where it occurs in the Westergaardodina lui-Westergaardodina ani Zone.

Remarks.-Westergaardodina sp. B is distinguished by its large size, relatively high turning point, and antero-posteriorly thick, semicircular lower part of element. The present specimen is insufficient to name a new species.

\section{Westergaardodina sp. C}

Figure 35.1
Description.—Large subsymmetrical, tricuspidate element. The anterior side is convex, whereas the posterior side is concave. The median projection is smaller than the lateral ones. It is characterized by a long keel which extends from tip to base and ends with a conical opening. The tips of lateral projections are directed outward. The large basal cavity is continuously open near the base.

Materials.—Eight specimens, but only one specimen is well preserved.

Occurrence.-Known from the Wa'ergang sections, where it occurs in the Eoconodontus Zone.

Comparison.-The specimen at hand are somewhat similar to Westergaardodina amplicava Müller, 1959 in gross morphology. They differ from the latter in having a wider median projection that has a larger funnel-shaped keel. Also, there are no keels on the lateral projections of the present species.

\section{Westergaardodina sp. D}

Figure 35.21

Description.-Small-sized, symmetrical, bicuspidate elements. The lateral projections diverge at an acute angle. The turning points are located relatively high. The anterior side is convex, whereas the posterior side is concave. Both vertical projections are fused up to a level that is a little below the turning points. The lateral cavities are small and extend upward to just a little below the turning points. A broad bulge is developed in the basal region.

Materials.-Nine specimens, but only one specimen is well preserved.

Occurrence.-Known from the Wangcun section, where it occurs in the Shandongodus priscus-Hunanognathus tricuspidatus Zone.

\section{Westergaardodina sp. E}

Figure 37.17

Description.-Medium-sized, subsymmetrical, bicuspidate elements which are distinguished by the broad U-shaped or saddle-shaped profile. There is no conspicuous boundary between the base and the two lateral projections, which extend laterally. The anterior side is convex, whereas the posterior side is concave and smaller than the anterior side. Both sides are fused along the entire upper margin of the element. Basal cavity is shallow and connected with the lateral cavities in some specimens that have deep lateral cavities.

Materials.—Eight specimens, but only one specimen is well preserved.

Occurrence.-Known from Wangcun section, where it occurs in the Westergaardodina cf. calix-Prooneotodus rotundatus Zone. 
Comparison.-Westergaardodina sp. E differs from any konwn species of Westergaardodina in its peculiar profile.

Genus Yongshunella Dong and Bergström, 2001a

Type species.-Yongshunella polymorpha Dong and Bergström, 2001a.

Yongshunella polymorpha Dong and Bergström, 2001a Figure 26.28

1993 Hertzina? sp. A. Dong, p. 351, pl. 5, figs. 1, 2, 6.

2001a Yongshunella polymorpha Dong and Bergström, p. 980 , pl. 1 , fig. 20 , pl. 2 , figs. $1-7,14,22$, pl. 4 , figs. 8, 14.

2006 Yongshunella polymorpha Dong and Bergström; Qi et al., p. 187, pl. 3, fig. 16.

2008 Yongshunella polymorpha Dong and Bergström; Bagnoli et al., p. 112, Fig. 3 (C-E).

Materials.-120 specimens.

Occurrence.-Known from the Paibi and Wangcun sections, where it ranges from the Gapparodus bisulcatusWestergaardodina brevidens Zone through the Westergaardodina lui-Westergaardodina ani Zone.

Remarks.-The present specimens agree well with described and figured by Dong and Bergström (2001a).

\section{Protoconodonts}

Phylum Chaetognatha Leuckart, 1854

Order Protoconodontida Landing, 1995

Genus Gapparodus Abaimova, 1978

Type species.-Hertzina? bisulcatus Müller, 1959.

Gapparodus bisulcatus (Müller, 1959)

Figure 28.24-28.26

1959 Hertzina? bisulcatus Müller, p. 456, pl. 13, figs. 22, 23, 27.

1966 Hertzina? bisulcatus Müller; Poulsen, p. 8, pl. 1, fig. 9, text-fig. 3.

1969 Hertzina bisulcatus Müller; Clark and Robison, p. 1045 , fig. 1 (d).

1969 Hertzina bisulcatus Müller; Clark and Miller, fig. 1 (2-4).

1971 Hertzina bisulcatus Müller; Müller, p. 12, pl. 1, fig. 7.

1973 Hertzina bisulcatus Müller; Özgül and Gedik, p. 47, pl. 1 , fig. 8 .

1974 Hertzina bokononi Landing, p. 1246, text-fig. 1 (h, i).

1974 Hertzina bisulcatus Müller; Landing, p. 1246, textfig. 1 (c, d, e, f). (with var. 1 and 2)

1975 Hertzina bisulcatus Müller; Lee, p. 80, pl. 1, figs. 2c, 3. 1976 Hertzina? bisulcatus Müller; Bengtson, p. 191, figs. 5-9.

1976 Hertzina? bisulcatus Müller; Abaimova and Ergaliev, p. 392, pl. 14, figs. 12-15.
1978 Gapparodus heckeri Abaimova, p. 496, pl. 7, figs. 3, 4, text-fig. 1 (e).

1978 Gapparodus bellus Abaimova, p. 497, pl. 7, figs. 6, 7, text-fig. 1 (g).

1978 Gapparodus bisulcatus (Müller); Abaimova, p. 497, p. 7, fig. 8, text-fig. 1 (h).

1978 Gapparodus porrectus Abaimova, p. 497, p. 7, fig. 5, text-fig. 1 (i).

1987 Gapparodus bisulcatus (Müller); An, p. 106, pl. 1, figs. 6, 8-9, 26. (part)

1990 Gapparodus bisulcatus (Müller); An and Zheng, p. 159, pl. 2, figs. 2, 8 .

1991 Gapparodus bisulcatus (Müller); Müller and Hinz, p. 25, pl. 3, figs. 1-42.

1993 Gapparodus bisulcatus (Müller); Dong, pl. 6, figs. 1, 3, 9, 12.

1994 Gapparodus bisulcatus (Müller); An and Mei, pl. 1, fig. 30.

1998 Gapparodus bisulcatus (Müller); Müller and Hinz, p. 96, fig. 2 (1-11).

2001a Gapparodus bisulcatus (Müller); Dong and Bergström, p. 964, pl. 3, figs. 1, 3, pl. 5, fig. 11.

2006 Gapparodus bisulcatus (Müller); Qi et al., p. 187, pl. 3, fig. 15.

2008 Gapparodus bisulcatus (Müller); Bagnoli et al., p. 112, fig. $3(\mathrm{O})$.

2009 Gapparodus bisulcatus (Müller); Lee et al., p. 420, fig. $6(1,11,15,22)$.

Description.-Moderate to large, slender coniform elements, evenly recurved over their entire length, so there is no conspicuous junction between cusp and base. Both anterior and posterior sides are convex. The lateral sides are characterized by distinct furrows, the position of which is variable. Basal cavities are very deep, with the apex extending nearly to the tip of the element. The cross section is circular at the apical portion and changes into a variable outline toward the base.

Materials._Approximately 1200 specimens.

Occurrence.-Known from the Paibi, Wangcun and Wa'ergang sections, where it ranges from the Gapparodus bisulcatusWestergaardodina brevidens Zone through the Westergaardodina lui-Westergaardodina ani Zone. The species is common in South China, Sweden, Denmark, and Kazakhstan and it has also been found in Ordos, northwestern China and eastern New York State. It is rare in most of North China and in most of North America. Its distribution suggests that it most probably preferred cold-water environments.

Remarks.-The specimens at hand agree in all respects with the elements described by Müller and Hinz (1991).

Genus Gumella Müller and Hinz, 1991

Type species._Gumella cuneata Müller and Hinz, 1991.

Gumella cuneata Müller and Hinz, 1991

Figure 19.1-19.3 
1971 Hertzina elongata Müller, pl. 1, fig. 2.

1987 Gapparodus bisulcatus (Müller); An, p. 106, pl. 1, fig. 10. (part)

1991 Gumella cuneata Müller and Hinz, p. 26, pl. 4, figs. 1-25, pl. 5, figs. 1-28.

1998 Gumella cuneata Müller and Hinz; Müller and Hinz p. 97, figs. 3, 4 (1-7), 5 (1-5).

2001a Gumella cuneata Müller and Hinz; Dong and Bergström, p. 964, pl. 1, figs. 5-7, 11, 19.

2008 Gumella cuneata Müller and Hinz; Bagnoli et al., p. 112 , fig. $3(\mathrm{~N})$.

2009 Gumella cuneata Müller and Hinz; Lee et al., p. 421, fig. 6 (19-21), p. 425, fig. 8 (15).

Description.-Coniform elements, moderate to large, proclined, with no conspicuous junction between cusp and base. Anterior sides convex, posterior sides flattened. Lateral sides characterized by symmetrical posterolateral furrows, the posterior sides of which are reinforced by an additional unit. Basal cavity very large and deep, with its apex extending nearly to the tip of the element. The cross section is circular at the apical portion and it changes into a variable outline toward the base.

Materials.—280 specimens.

Occurrence.-Known from the Paibi, Wangcun, and Wa'ergang sections, where it ranges from the Gapparodus bisulcatusWestergaardodina brevidens Zone through the Westergaardodina lui-Westergaardodina ani Zone.

Remarks.-Gumella cuneata and Gapparodus bisulcatus are similar in gross morphology, but the former species has more distinct and deeper lateral furrows reinforced by an additional unit (Müller and Hinz, 1991, p. 26). Although the internal structure of the two species represents the same type, the structure of $G$. cuneata appears to be somewhat more complex. The fact that elements of $G$. cuneata and $G$. bisulcatus frequently occur together and are quite similar in external and internal morphology may indicate that they represent the same multi-element species.

Genus Huayuanodontus Dong and Bergström, 2001a

Type species.—Albiconus? tricornis Dong, 1993.

Huayuanodontus tricornis (Dong, 1993)

Figure 19.14-19.16, 19.22-19.24

1993 Albiconus? tricornis Dong, p. 349, pl. 6, figs. 4, 5, 11, 15, 20-22.

2001a Huayuanodontus tricornis (Dong); Dong and Bergström, p. 964, pl. 2, figs. 15-16, pl. 3, figs. 2, 4, 8, 11.

2006 Huayuanodontus tricornis (Dong); Qi et al., p. 187, pl. 3, figs. 13-14.

2008 Huayuanodontus tricornis (Dong); Bagnoli et al., p. 112 , fig. 3 (I).

2013 Huayuanodontus tricornis (Dong); Lee, p. 168, pl. 1, figs. 24-26.
Materials.-600 specimens.

Occurrence.-Present in the Paibi, Wangcun, and Wa'ergang sections, where it ranges from the Gapparodus bisulcatusWestergaardodina brevidens Zone through the Proconodontus tenuiserratus Zone.

Remarks.-The specimens at hand agree well with Huayuanodontus tricornis described and figured by Dong and Bergström (2001a). The present species differs from Albiconus postcostatus Miller in having a triangular, rather than roundly triangular, cross-section, and a more slender shape of the element which is not laterally compressed, as is Miller's species. The present species occurs in significantly older strata than A. postcostatus, which is present in strata near the CambrianOrdovician boundary. The present form looks like a protoconodont. However, preliminary histological investigation indicates it is neither a protoconodont nor a paraconodont. It is also not a euconodont (Dong, 2007a). Therefore, further detailed histological work is needed to substantiate the nature of the present genus, although it seems beyond the scope of this study.

Genus Paibiconus Dong, 1993

Type species._Paibiconus proarcuatus Dong, 1993.

Paibiconus proarcuatus Dong, 1993

Figure 31.1-31.4

1993 Paibiconus proarcuatus Dong, p. 353, pl. 5, figs. 12-16.

2001a Paibiconus proarcuatus Dong; Dong and Bergström, p. 969 , pl. 1, fig. 4 , pl. 2, fig. 11, pl. 3, figs. 5-7.

2008 Paibiconus proarcuatus Dong; Bagnoli et al., p. 112, fig. 3 (Q).

Materials._660 specimens.

Occurrence.-Known from the Paibi, Wa'ergang and Wangcun sections, where it occurs from the Gapparodus bisulcatusWestergaardodina brevidens Zone through the Westergaardodina matsushitai-Westergaardodina grandidens Zone.

Remarks.-The specimens at hand agree well with those described and figured by Dong and Bergström (2001a). Histological investigation verified that this form is a protoconodont (Dong, 2004).

Genus Phakelodus Miller, 1984

Type species._Oneotodus tenuis (Müller, 1959).

Remarks.-Müller and Hinz (1991, p. 32) separated specimens of Oneotodus tenuis into two taxa, Phakelodus tenuis and Phakelodus elongatus, stating "both $P$. elongatus and $P$. tenuis are long-ranging and widespread". Although they appear in strikingly similar clusters, they were not regarded as morphotypes of a single species. All recognized clusters are unimembrate. Further, the occurrence of these species is indeed overlapping but not 
consistent enough (Müller and Hinz, 1991, table 3) for them to represent different morphotypes of a single species.

We have numerous specimens of these taxa from Hunan, where both are long-ranging and co-occurring, and are found unimemberate clusters that contain either the Phakelodus tenuis type or the Phakelodus elongatus type. However, this fact does not prove that these forms represent different species because it is quite possible that a protoconodont animal could have possessed more than one type of cluster. It is also possible that this could be an example of sexual dimorphism. In this study, we consider both these two types of elements, $P$. tenuis type (morphotype A) and $P$. elongatus type (morphotype B) to represent $P$. tenuis.

No clusters of the stout species Phakelodus simplex Müller and Hinz, 1991 have been found anywhere. In gross morphology, that species is more reminiscent of the paraconodont Prooneotodus gallatini, except that $P$. simplex has a protoconodont internal structure. It may be that $P$. simplex should not be referred to Phakelodus.

Phakelodus tenuis (Müller, 1959)

Figure 31.5-31.10

1959 Oneotodus tenuis Müller, p. 457, pl. 13, figs. 11, 13, 14, 20.

1990 Prooneotodus tenuis (Müller); An and Zheng, p. 160, pl. 1, figs. 1, 6, 7 .

1991 Phakelodus tenuis (Müller); Müller and Hinz, p. 33, pl. 1, figs. 6, 10, 11, 15-21, 23, pl. 2, figs. 1-24. (including extensive synonymy to 1988).

1991 Phakelodus elongatus (An); Müller and Hinz, p. 32, pl. 1, figs. 1-5, 7-9, 12-14, 22. (including extensive synonymy to 1988).

1993 Phakelodus tenuis (Müller); Dong, pl. 4, figs. 12, 13, pl. 6, figs. 2, 8, 17.

1993 Phakelodus tenuis (Müller); Landing, p. 6, fig. 4 (1).

1993 Phakelodus elongatus (An); Dong, pl. 4, figs. 10, 11, pl. 6, figs. 6, 7 .

1994 Phakelodus tenuis (Müller); An and Mei, pl. 1, fig. 23.

1998 Phakelodus elongatus (An); Rao and Tortello, p. 45, pl. 2, figs. 16, 17.

1999 Phakelodus tenuis (Müller); Göncüoğlu and Kozur, p. 599, fig. 4 (B).

2000 Phakelodus tenuis (Müller); Dubinina, p. 166, pl. 1, fig. 7, pl. 2, figs. 10-12, 25.

2000 Phakelodus? cavatua Dubinina, p. 166, pl. 1, figs. 19, 19a, 27, 27a.

2001a Phakelodus tenuis (Müller); Dong and Bergström, p. 970, pl. 3, fig. 19, pl. 5, figs. 8, 10, pl. 6, fig. 5 .

2001 Phakelodus tenuis (Müller); Lee, p. 449, fig. 6 (1).

2002 Phakelodus elongatus (An); Lee, p. 25, pl. 1, fig. 1.

2002 Phakelodus tenuis (Müller); Lee, p. 25, pl. 1, fig. 2.

2002 Phakelodus tenuis (Müller); Lee, p. 164, pl. 1, fig. 8.

2004 Phakelodus elongatus (An); Lee, p. 60, fig. 5 (A).

2007 'Phakelodus elongatus' (Zhang in An et al., 1983); Landing et al., fig. $6(\mathrm{u})$.

2007 Phakelodus tenuis (Müller); Landing et al., fig. 6 (s).

2008 Phakelodus? sp. Bagnoli et al., p. 112, fig. 3 (H).
2009 Phakelodus tenuis (Müller); Lee et al., p. 420, fig. 6 $(12,14)$.

2009 Phakelodus elongatus (An); Lee et al., p. 420, fig. $6(9,10)$.

Materials.-Approximately 20,000 specimens.

Occurrence.-Phakelodus tenuis is present in the Paibi, Wangcun, and Wa'ergang sections. It ranges from the Gapparodus bisulcatus-Westergaardodina brevidens Zone through the Cordylodus lindstromi Zone (Lower Part).

Remarks.-Our specimens agree well with Phakelodus tenuis type (morphotype A) and Phakelodus elongatus type (morphotype B), respectively.

\section{Acknowledgments}

X.-P Dong thanks W.-C Lai and W. Guo for field assistance; S. M. Bergström, J. E. Repetski, and S. Stouge for their suggestions and comments; and P.C.J. Donoghue for his work on conodont histology and for his valuable advice on this manuscript. This manuscript is greatly improved by the substantive scientific and editorial comments of the reviewers J.E. Repetski and J.F. Miller. This work was supported by the National Natural Science Foundation of China (grant nos. 41372015, 41072006, 40772008, 40572003, 40372001, 40072007, 49772083, and 49272077 to X.P.D.; 41102003 and J1210006 to H.Z.), State Key Laboratory of Palaeobiology and Stratigraphy, Nanjing Institute of Geology and Palaeontology, Chinese Academy of Sciences (grant nos. 103102, 083101, 023106, 973103, and 913114 to X.P.D.; 20132107 to H.Z.), the Research Fund for Doctoral Program of High Education (grant nos. 20060001059 and 2000000127 to X.P.D.), and Peking University.

\section{References}

Abaimova, G.P., 1978, Late Cambrian conodonts of central Kazakhstan: Paleontological Journal, 1978, p. 493-504.

Abaimova, G.P., 1983, Conodonts and other Middle-Upper Cambrian remains of the Maly Karatau, in Apollonov, M.K., Bandaletov, S.M., and Ivshin, N.K., eds., The Lower Paleozoic Stratigraphy and Paleontology of Kazakhstan: Alma-Ata, USSR, Nauka SSR Publishing House, p. 96-104. [in Russian]

Abaimova, G.P., and Ergaliev, G.K., 1976, O nakhodke konodontov v srednem i verkhnem kembrii Malogo Karatau (On finds of conodonts in the Middle and Upper Cambrian of Malyi Karatau): Trudy Instituta Geologii i Geofiziki SO AN SSSR, v. 333, p. 390-394.

Abaimova, G.P., and Markov, E.P., 1977, Pervye nakhodki konodontov nizhneordovikskoi zony Cordylodus proavus na yuge Sibiriskoi Platformy (The first finds of conodonts in the Lower Ordovician Cordylodus proavus Zone in the south of the Siberian Platform), in Sokolov, B.S., and Kanygin, A.V., eds., Problemy Stratigrafii Ordovika i Sibiri: Trudy Instituta Geologii i Geofiziki SO AN SSSR, v. 372, Novosibirsk, p. 86-94.

Aldridge, R.J., 1987, Conodont palaeobiology: a historical review, in Aldridge, R.J., ed., Palaeobiology of Conodonts: Chichester, UK, Ellis Horwood, p. 11-34.

Aldridge, R.J., and Purnell, M.A., 1996, The conodont controversies: Tree, v. 11, p. $463-468$.

Aldridge, R.J., Briggs, D.E.G., Smith, M.P., Clarkson, E.N.K., and Clark, N.D.L., 1993, The anatomy of conodonts: Philosophical Transactions of the Royal Society of London Series B, v. 340, p. 405-421.

An, T.-X., 1981, Recent progress in Cambrian and Ordovician conodont biostratigraphy in China: Geological Society of America Special Paper, v. 187 , p. $209-224$

An, T.-X., 1982, Study on the Cambrian conodonts from North and Northeast China: Science Reports, Institute Geoscience University Tsukuba, Sec. B, v. 3, p. 113-159. 
An, T.-X., 1987, The Lower Paleozoic Conodonts of South China. The Publishing House of Peking University, Beijing, 238 p. [in Chinese]

An, T.-X., and Hu, J.M., 1985, The Cambrian and Ordovician conodonts from Northwest part of Hunan, Papers of Petroleum Geology and Paleontology: Beijing, Geological Publishing House, p. 15-26. [in Chinese]

An, T.-X., and Mei, S.L., 1994, On evolution of Cambrian conodonts: Acta Palaeontologica Sinica, v. 33, p. 525-544. [in Chinese with English summary]

An, T.-X., and Zheng, Z.C., 1990, The conodonts of the marginal areas around the Ordos Basin: Beijing, North China Science Press, 201 p. [in Chinese with English abstract]

An, T.-X., Du, G.-Q., Gao, Q.-Q., Chen, Q.-B., and Li, W.T., 1981, Conodont biostratigraphy of the Ordovician System of Yichang, Hubei: Selected papers on the First Convention of Micropalaeontological Society of China, p. 105-113. [in Chinese]

An, T.-X., Zhang, F., Xiang, W., Zhang, Y., Xu, W., Zhang, H.-J., Jiang, D.B., Yang, C.-S., Lin, L.D., Cui, Z.-T., and Yang, X.-C., 1983, The Conodonts of North China and the Adjacent Regions: Beijing, Science Press, 223 p. [in Chinese with English abstract]

Andres, D., 1988, Struktur, apparate und phylogenie primitiver conodonten: Paläontographica Abt. A, v. 200, p. 1-105.

Azmi, R.J., 1983, Microfauna and age of the lower Tal Phosphorite of Mussoorie Syncline, Gahwal Lesser Himalaya, India: Himalayan Geology, v. 11, p. 273-409.

Bagnoli, G., and Stouge, S., 2014, Upper Furongian (Cambrian) conodonts from the Degerhamn quarry road section, southern Öland, Sweden: GFF, http://dx.doi.org/10.1080/11035897.2013.858768

Bagnoli, G., and Qi, Y.-P., 2011, Conodonts from the proposed GSSP for the base of Cambrian Stage 9 at Duibian, Zhejiang, South China: a revision: Palaeoworld, v. 20, p. 8-14.

Bagnoli, G., Barnes, C.R., and Stevens, R.K., 1987, Lower Ordovician (Tremadocian) conodonts from Broom Point and Green Point, western Newfoundland: Estratto dal Bolletino Della Societá Italiana, v. 25, p. 145-158.

Bagnoli, G., Qi, Y.-P., and Wang, Z.H., 2008, Conodonts from the Global Stratotype section for the base of the Guzhangian Stage (Cambrian) at Luoyixi, Hunan, South China: Palaeoworld, v. 17, p. 108-114.

Barnes, C.R., 1988, The proposed Cambrian-Ordovician global boundary stratotype and point (GSSP) in Western Newfoundland, Canada: Geological Magazine, v. 125 , p. $381-414$

Bateson, W., 1886, The ancestry of the Chordata: Quarterly Journal of Microscopical Science, v. 26, p. 218-571.

Bednarczyk, W.. 1979, Upper Cambrian to lower Ordovician conodonts of Leba elevation, NW Poland, and their stratigraphic significance: Acta Geologica Polonica, v. 29, p. 409-422.

Bengtson, S., 1976, The structure of some Middle Cambrian conodonts, and the early evolution of conodont structure and function: Lethaia, v. 9, p. 185-206.

Bengtson, S., 1983, The early history of the Conodonta: Fossils and Strata, v. 15, p. 5-19.

Branson, E.B., 1938, Stratigraphy and paleontology of the Lower Mississippian of Missouri, part 1: University of Missouri Studies, v. 29, p. 1-208

Branson, E.B., and Mehl, M.G., 1933, Conodont from the Jeffeson city (Lower Ordovician) of Missouri: University Missouri Studies, v. 8, p. 53-64.

Briggs, D.E.G., Clarkson, E.N.K., and Aldridge, R.J., 1983, The conodont animal: Lethaia, v. 16, p. 1-14.

Buggisch, W., and Repetski, J.E., 1987, Uppermost Cambrian (?) and Tremadocian conodonts from Handler Ridge, Robertson Bay Terrane, North Victoria Land, Antarctica: Geologisches Jahrbuch, v. 66, p. 145-185.

Chen, F., and Dong, X.P., 2008, Middle Cambrian highly modified sponge spicules from Western Hunan, South China: Acta Scientiarum Naturlium Naturlium Universitatis Pekinensis, v. 44, p. 883-889. [in Chinese]

Chen, J.-Y., and Gong, W.-L., 1986, Conodonts, in Chen, J.-Y., ed., Contribution to Dayangcha International Conference on Cambrian-Ordovician Boundary: Beijing, China Prospect Publishing House, p. 93-223.

Chen, J.-Y., Qian, Y.-Y., Lin, Y.-K., Zhang, J.-M., Wang, Z.-H., Yin, L.-M., and Erdtmann, B.D., 1985, Study on the Cambrian-Ordovician boundary strata and its biota in Dayangcha, Hunjiang, Jilin, China: Beijing, China Prospecting Publishing House, $138 \mathrm{p}$.

Chen, M.-J., Zhang, J.H., and Yu, Q., 1986, Cambrian-Ordovician conodonts from the Jiangnan Region: Acta Micropalaeontologica Sinica, v. 3, p. 361-372.

Cheng, G., Peng, F., Duan, B.-C., and Dong, X.P., 2011, Internal structure of Cambrian fossil embryo Markuelia revealed in the light of synchrotron radiation X-ray tomographic microscopy: Acta Geologica Sinica, v. 85, p. 81-90.

Clark, D.L., and Miller, J.F., 1969, Early evolution of conodonts: Geological Society of America Bulletin, v. 80, p. 125-134.

Clark, D.L., and Robison, R.A., 1969, Oldest conodonts in North America: Palaeontology, v. 43, p. 1044-1046.

Cooper, R.A., Nowlan, G.S., and Williams, S.H., 2001, Global Stratotype Section and Point for base of the Ordovician System: Episodes, v. 42, p. 19-28.
Ding, L.-S., Cao, H.-H., Bao, D.-X., and Yang, Y.-L., 1993a, Cambrian conodont biostratigraphy and lithofacies paleogeography, in Wang, C.-Y., ed., Conodonts of the Lower Yangtze Valley - An Index to Biostratigraphy and Organic Metamorphic Maturity: Beijing, Science Press, p. 1-15. [in Chinese]

Ding, L.-S., Chen, M.-J., Zhang, J.-H., Cao, H.-H., Bao, D.-X., and Yang, Y.-L., 1993b, Ordovician conodont biostratigraphy and lithofacies paleogeography, in Wang, C.-Y., ed., Conodonts of the Lower Yangtze Valley - An Index to Biostratigraphy and Organic Metamorphic Maturity: Beijing, Science Press, p. 16-52. [in Chinese]

Dong, X.-P., 1983, On Cambrian-Ordovician boundary at Huanghuachang of Yichang, Hubei, in Nanjing Institute of Geology and Palaeontology, Academia Sinica, ed., Papers for the Symposium on the Cambrian-Ordovician and Ordovician-Silurian Boundaries, Nanjing, China: Hefei, Anhui Science and Technology Publishing House, p. 53-61.

Dong, X.-P., 1985, Conodont-based Cambrian-Ordovician boundary at Huanghuachang of Yichang, Hubei, in Nanjing Institute of Geology and Palaeontology, Academia Sinica, ed., Papers for the Symposium on the Cambrian-Ordovician and Ordovician-Silurian Boundaries, Nanjing, China: Hefei, Anhui Science and Technology Publishing House, p. 383-412.

Dong, X.-P., 1987, Late Cambrian and Early Ordovician conodonts from Chuxian, Anhui. in Nanjing Institute of Geology and Palaeontology, Academia Sinica, ed., Collection of Postgraduate Theses No. 1: Nanjing, Jiangsu Science and Technology Publishing House, p. 135-184. [in Chinese with English Abstract]

Dong, X.-P., 1990a, A potential candidate for the Middle-Upper Cambrian boundary stratotype - an introduction to the Paibi section in Huayuan, Hunan: Acta Geologica Sinica (Chinese version), v. 64, p. 62-79. (Acta Geologica Sinica [English version], 1990, v. 3, p. 309-327)

Dong, X.-P., 1990b, Both Agnostid and Conodont based Middle-Upper Cambrian boundary in Huayuan, Hunan: Third International Symposium on the Cambrian System, Novosibirsk, U. S. S. R., p. 86-88.

Dong, X.-P., 1991, Late Middle and early Late Cambrian Agnostids in Huayuan, Hunan: Acta Palaeontologica Sinica, v. 30, p. 439-457. [in Chinese with English abstract]

Dong, X.-P., 1992, The relationship between the relative values of the palaeotemperature indicated by ${ }^{18} \mathrm{O}$ and Cambrian conodont diversity: Geological Review, v. 38, p. 368-371. [in Chinese with English abstract]

Dong, X.-P., 1993, Late Middle and early Late Cambrian conodonts from Huayuan, Hunan: Acta Micropalaeontologica Sinica, v. 10, p. 345-362. [in English with Chinese title and abstract]

Dong, X.-P., 1997, Evolutionary trends of Paraconodonts: Geological Review, v. 43, p. 498-502. [in Chinese with English abstract]

Dong, X.-P., 1999a, Cambrian conodont biostratigraphy of South China: Geoscience, v. 13, p. 244-245. [in Chinese]

Dong, X.-P., 1999b, Succession of Cambrian conodonts from South China: Science in China Series D Earth Science (Chinese Version), v. 29, p. 339-346. [in Chinese]

Dong, X.-P., 2000, Succession of Cambrian conodonts from South China: Science in China Series D Earth Science (English Version), v. 43, p. $317-327$.

Dong, X.-P., 2001, Provincialism of the late Middle through Late Cambrian paraconodonts and protoconodonts: Chinese Science Bulletin (Chinese Version), v. 46, p. 158-163. [Chinese Science Bulletin (English Version), v. 46, p. $433-438]$

Dong, X.-P., 2004, On the evolution and histology of some Cambrian protoconodonts, paraconodonts and earliest euconodonts: Science in China Series D Earth Science, v. 47, p. 577-584.

Dong, X.-P., 2007a, Developmental sequence of Cambrian embryo Markuelia: Chinese Science Bulletin, v. 52, p. 929-935.

Dong, X.-P., 2007b, Study on histology and comparative histology of some protoconodonts, paraconodonts and earliest euconodonts: Acta Micropalaeontologica Sinica, v. 24, p. 113-124. [in Chinese with English abstract]

Dong, X.-P., 2009a, Cambrian fossil embryos from western Hunan, South China: Acta Geologica Sinica, v. 83, p. 429-439.

Dong, X.-P., 2009b, The anatomy, affinity and developmental sequences of Cambrian embryos: Acta Palaeontologica Sinica, v. 48, p. 390-401. [in Chinese with English abstract]

Dong, X.-P., and Bergström, S.M., 2000a, Paracondonts as guide fossils in the potential global stratotypes for the Middle-Upper Cambrian Series boundary in Hunan, China: The Geological Society of America, Abstracts with Programs, v. 32, p. A-11.

Dong, X.-P., and Bergström, S.M., 2000b, Protoconodonts and paracondonts as guide fossils in the proposed stratotypes of the global Middle-Upper Cambrian series boundary in Hunan, China: The Geological Society of America, Abstracts with Programs, v. 32, p. A-448.

Dong, X.-P., and Bergström, S.M., 2001a, Middle and Upper Cambrian protoconodonts and paraconodonts from Hunan, South China: Palaeontology, v. 44 , p. 949-985. 
Dong, X.-P., and Bergström, S.M., 2001b, Stratigraphic significance of Middle and Upper Cambrian protocondonts and paraconodonts from Hunan, South China: Palaeoworld, v. 13, p. 307-309.

Dong, X.-P., and Knoll, A.H., 1996, Middle and Late Cambrian sponge spicules from Hunan, China: Journal of Paleontology, v. 70, p. 173-184.

Dong, X.-P., Knoll, A.H., and Lipps, J.H., 1997, Late Cambrian radiolaria from Hunan, China: Journal of Paleontology, v. 71, p. 753-758.

Dong, X.-P., Repetski, J.E., and Bergström, S.M., 2001, A conodont biozonation for the Middle Cambrian through lowermost Ordovician in Hunan, South China: Palaeoworld, v. 13, p. 252-255.

Dong, X.-P., Bergström, S.M., and Repetski, J.E., 2004a, Conodont as useful guide fossil in the Cambrian: A conodont zonal succession from the Middle Cambrian to the lowermost Ordovician in Hunan, China: Geological Association of Canada, Abstract 29, p. 91.

Dong, X.-P., Donoghue, P.C.J., Cheng, H., and Liu, J.-B., 2004b, Fossil embryos from the Middle and Late Cambrian period of Hunan, south China: Nature, v. 427 , p. $237-240$.

Dong, X.-P., Repetski, J.E., and Bergström, S.M., 2004c, Conodont biostratigraphy of the Middle Cambrian through lowermost Ordovician in Hunan, South China: Acta Geologica Sinica, v. 78, p. 1185-1206.

Dong, X.-P., Donoghue, P.C.J., Cunningham, J.A., Liu, J.-B., and Cheng, H., 2005a, The affinity and phylogenetic significance of Markuelia: Evolution \& Development, v. 7, p. 468-482.

Dong, X.-P., Donoghue, P.C.J., Liu, Z., Liu, J., and Peng, F., 2005b, The fossils of Orsten-type preservation from Middle and Upper Cambrian in Hunan, China-Three-dimensionally preserved soft-bodied fossils (Arthropods) Chinese Science Bulletin, v. 50, p. 1352-1357.

Dong, X.-P., Donoghue, P.C.J., and Repetski, J.E., 2005c, Basal tissue structure in the earliest euconodonts: testing hypotheses of developmental plasticity in euconodont phylogeny: Palaeontology, v. 48, p. 411-421.

Dong, X.-P., Bengtson, S., Gostling, N.J., Cunningham, J.A., Harvey, T.H.P. Kouchinsky, A., Val'kov, A.K., Repetski, J.E., Stampanoni, M., Marone, F., and Donoghue, P.C.J., 2010, The anatomy, taphonomy, taxonomy and systematic affinity of Markuelia: Early Cambrian to Early Ordovician Scalidophorans: Palaeontology, v. 53, p. 1291-1314.

Donoghue, P.C.J., Forey, P.L., and Aldridge, R.J., 2000, Conodont affinity and chordate phylogeny: Biological Reviews, v. 75, p. 191-251.

Druce, E.C., and Jones, P.J., 1971, Cambro-Ordovician conodonts from the Burke River structural belt Queensland: Bureau of Mineral Resources, Geology and Geophysics, Bulletin, v. 110, p. 1-159.

Duan, B.-C., Dong, X.-P., and Donoghue, P.C.J., 2012, New palaeoscolecid worms from the Furongian (Upper Cambrian) of Hunan, South China: is Markuelia an embryonic palaeoscolecid? Palaeontology, v. 55, p. 613-622.

Dubinina, S.V., 2000, Conodonts and zonal stratigraphy of the CambrianOrdovician boundary deposits: Transactions, v. 517, p. 1-237. [in Russian]

Ethington, R.L., 1959, Conodonts from the Ordovician Galina Formation Journal of Paleontology, v. 33, p. 257-292.

Ethington, R.L., and Clark, D.L., 1971, Lower Ordovician conodonts in North America, in Sweet, W.C., and Bergström, S., eds., Conodont Biostratigraphy: Geological Society of America Memoir, v. 127, p. 63-82.

Fåhræus, L.E., and Roy, K., 1993, Conodonts from the Cambro-Ordovician Cooks Brook and Middle Arm formations, Bay of Islands, western Newfoundland: Geologica et Palaeontologica, v. 27, p. 1-153.

Fortey, R.A., Landing, E., and Skevington, D., 1982, Cambrian-Ordovician boundary sections in the Cow Head Group, Western Newfoundland, in Bassett, M.G., and Dean, W.T., eds., The Cambrian-Ordovician boundary: sections, fossil distribution, and correlations: National Museum of Wales, Geological Series 3, p. 95-129.

Furnish, W.M., 1938, Conodonts from the Prairie du Chien (Lower Ordovician) beds of upper Mississippi Valley: Journal of Paleontology, v. 12, p. 318-340.

Gabbott, S.E., Aldridge, R.J., and Theron, J.N., 1995, A giant conodont with preserved muscle tissue from the Upper Ordovician of South Africa: Nature, v. 374 , p. $800-803$

Göncüoğlu, Y., and Kozur, H.W., 2000, Upper Cambrian and Lower Ordovician conodonts from the Antalya Unit in the Alanya Tectonic Window, south Turkey: Neues Jahrbuch für Geologie und Paläontologie, Mh. v. 1999, p. 593-604.

Grant, R.E., 1965, Faunas and stratigraphy of the Snowy Range Formation (Upper Cambrian) in southwestern Montana and northwestern Wyoming: Geological Society of America Memoir, v. 96, p. 143-164.

Guo, W., Dong, X.-P., Zeng, X.-C., and Zhao, L., 2005a, Histological observation of some earliest euconodonts from Upper Cambrian in Liaoning: Progress in Natural Science, v. 15, p. 1084-1088.

Guo, W., Dong, X.-P., Zeng, X.-C., and Zhao, L., 2005b, Camparative histology of the earliest euconodonts: Acta Scientiarum Naturlium Universitatis Pekinensis, v. 41, p. 219-224.

Heinsalu, H., Kaljo, D., Kurvits, T., and Viira, V., 2003, The stratotype of the Orasoja Member (Tremadocian, Northeast Estonia): lithology, mineralogy, and biostratigraphy: Proceedings of Estonian Academy Science of Geology, v. 52 , p. $135-154$.

Heredia, S., and Bordonaro, O., 1988, Conodontes de la formacion La Gruz (Cambrian Superior), San Isidro, provincial de Mendoza, R. Argentina: IV Congressito Argentino de Paleontologia y Biostratigrafia, Actas 3, p. $189-202$.

Jegorova, L.I., Xiang, L.-W., Lee, S.-C., Nan, S.-J., and Kuo, C.-M., 1963, The Cambrian trilobite faunas of Guizhou and western Hunan: Special Paper, Institute of Geology and Mineral Resources, B, Stratigraphy and Palaeontology, v. 3, p. 1-117. [in Chinese]

Ji, Z., and Barnes, C.R., 1994, Lower Ordovician conodonts of the St. George Group, Port au Port Peninsula, western Newfoundland, Canada: Palaeontographic Canadiana, v. 11, p. 1-149.

Kalio, D., Borovko, N., Heinsalu, H., Hazanovits, K., Mens, K., Popov, L. Sergejeva, S., Sobolevskaja, R., and Viira, V., 1986, Kambriumi ja ordovitsiumi piir Balti-Laadoga klindi piirkonnas (Põhja-Eesti ja Leningradi oblast, NSV Liit) (The Cambro-Ordovician boundary in the Baltic Ladoga Clint Area [North Estonia and Leningrad Region, USSR]): Proceedings of the Academy of Sciences of Estonian SSSR: Geology, v. 35, p. $97-108$.

Kalio, D., Heinsalu, H., Mens, K., Puura, I., and Viira, V., 1988, CambrianOrdovician boundary beds at Tänismägi, Tallinn, North Estonia: Geological Magazine, v. 125, p. 457-463.

Kobayashi. 1935, The Cambro-Ordovician formations and faunas of South Chosen. Palaeontology, Pt. III, Cambrian faunas of South Chosen with a special study on the Cambrian trilobite genera and families: Journal of the Faculty of Science, Imperial University of Tokyo, v. 4, p. 49-344.

Landing, E., 1974, Early and Middle Cambrian conodonts from the Taconic allochthon, eastern New York: Journal of Paleontology, v. 48, p. 1241-1248.

Landing, E., 1979, Conodonts and biostratigraphy of the Hoyt Limestone (Late Cambrian, Trempealeauan), Eastern New York: Journal of Paleontology, v. 53, p. 1023-1029.

Landing, E., 1983, Highgate Gorge: Upper Cambrian and Lower Ordovician continental slope deposition and biostratigraphy, northwestern Vermont: Journal of Paleontology, v. 57, p. 1149-1187.

Landing, E., 1993, Cambrian-Ordovician boundary in the Taconic Allochthon, eastern New York, and its interregional correlation: Journal of Paleontology, v. 67 , p. $1-19$.

Landing, E., 1995, Upper Placentian-Branchian Series of mainland Nova Scotia (middle-upper Lower Cambrian): Faunas, paleoenvironments, and stratigraphic revision: Journal of Paleontology, v. 69, p. 475-495.

Landing, E., and Westrop, S.R., 2006, Early Ordovician faunas, stratigraphy, and sea-level history of the middle Beekmantown Group, northeastern New York: Journal of Paleontology, v. 80, p. 958-980.

Landing, E., Ludvigen, R., and von Bitter, P.H., 1980, Upper Cambrian to Lower Ordovician conodont biostratigraphy and biofacies, Rabbitikettle Formation, District of Mackenzie: Life Science Contribution, Royal Ontario Museum, v. 126, p. 1-42.

Landing, E., Barnes, C.R., and Stevens, R.K., 1986, Tempo of earliest Ordovician graptolite successions: conodont-based correlation from the Tremadocian of Quebec: Canadian Journal of Earth Science, v. 23, p. 1928-1949.

Landing, E., Westrop, S.R., and van Aller Hernick, L., 2003, Uppermost Cambrian-Ordovician faunas and Laurentian platform sequence stratigraphy, eastern New York and Vermont: Journal of Paleontology, v. 77, p. $78-98$

Landing, E., Westrop, S.R., and Keppie, J.D., 2007, Terminal Cambrian and Lowest Ordovician succession of Mexican West Gondwana: biotas and sequence stratigraphy of the Tiñu Formation: Geological Magazine, v. 146, p. 909-936.

Landing, E., Westrop, S.R., and Adrain, J.M., 2011, The Lawsonian Stage - the Eoconodontus notchpeakensis (Miller, 1969) FAD and HERB carbon isotope excursion define a globally correlatable terminal Cambrian stage: Bulletin of Geosciences, v. 86, p. 621-640.

Lee, B.-S., 2001, Conodont biostratigraphy of the Hwajeol Formation (Upper Cambrian) in northern Taegaeg City, Korea: Ameghiniana, v. 38 , p. $441-453$.

Lee, B.-S., 2002a, Conodonts from the Upper Cambrian Sesong and Hwajeol Formation in the Sabuk Area, South Korea: Acta Geologica Sinica, v. 76, p. $155-165$.

Lee, B.-S., 2002b, Revision of conodont zones of the Hwajeol Formation (Upper Cambrian-Lower Ordovician), Kangweon-Do, South Korea: Tikhooceanskaya geologiya (Geology of the Pacific Ocean), v. 21, p. 18-30. [in English]

Lee, B.-S., 2004, Late Cambrian conodonts from Cheungsan, Kangwon Province, Korea: Alcheringa, v. 28, p. 53-64.

Lee, B.-S., 2008a, Taxonomic revisions of Upper Cambrian Granatodontus Chen et Gong, 1986 of the Dasytodus Lineage (Conodonta): Geosciences Journal, v. 12, p. 227-231. 
Lee, B.-S., 2008b, Conodonts from the Hwajeol Formation (Upper Cambrian) in the Seokgaejae area, southeast margin of the Taebaeksan Basin: Geosciences Journal, v. 12, p. 233-242.

Lee, B.-S., 2013, Middle Cambrian (upper Series 3) protoconodonts and paraconodonts from the Machari Formation at Eodungol Section, Yeongwol, Korea: Journal of Earth Science, v. 24, p. 157-169.

Lee, B.-S., and Lee, H.-Y., 1988, Upper Cambrian conodonts from the Hwajeol Formation in the Southern limb of the Baegunsan Syncline, Eastern Yeongweol and Samcheog areas, Kangweon-Do, Korea: Journal of Geological Society of Korea, v. 24, p. 356-375.

Lee, B.-S., Lee, J.-D., and Ko, E.J., 1996, Lithostratigraphy and conodont biostratigraphy of the Choseon Supergroup (Cambro-Ordovician) in the eastern Danyang area: Journal of Paleontology Society of Korea, v. 12, p. 85-104.

Lee, B.-S., Lee, Y.-I., Miller, J.F., and Jeong, H., 2009, Conodont fauna of the Machari Formation (Middle and Upper Cambrian), Yeongweol area, Gangweon Province, Korea: Ameghiniana, v. 46, p. 407-430.

Lee, H.-Y., 1975, Conodonts from the Upper Cambrian Formation, KangweonDo, South Korea: Yonseinonchog, Yonsei Univisity Graduate School Bulletin, v. 12, p. 97-110.

Leuckart, R., 1854, Bericht über die Leistungen in der Naturgeschichte der niederen Thiere während der Jahre 1848-1853: Archiv für Naturgeschichte, v. 20 , p. $289-473$

Lin, H.-L., Wang, J.-G., and Liu, Y.R., 1966, Cambrian strata in Songtao, Tongren, and Luxi, Hunan: Acta Stratigraphica Sinica, v. 1, p. 4-23. [in Chinese]

Lin, T.-R., 1991, Middle Cambrian stratigraphy and trilobite fauna of Taoyuan, NW Hunan: Acta Palaeontologica Sinica, v. 30, p. 360-376. [in Chinese with English abstract]

Lindström, M., 1955, Conodonts from the lowermost Ordovician strata of south-central Sweden: Geologiska Föreningen i Stockolm Förhandlingar, v. 76, p. $517-604$.

Lindström, M., 1971, Lower Ordovician conodonts of Europe, in Sweet, W.C., and Bergström, S.M., eds., Symposium on Conodont Biostratigraphy: Geological Society of America Memoir, v. 127, p. 21-61.

Liu, J., and Dong, X.-P., 2007, Skara hunanensis, a new species of Skaracarida (Crustacea) from Upper Cambrian (Furongian) of Hunan, south China: Progress in Natural Sciences, v. 17, p. 934-942.

Liu, Z., and Dong, X.-P., 2009, Vestrogothia spinata the fossils of Orsten-type preservation (Phosphatocopina, Crustacean) from Upper Cambrian in Western Hunan, South China: Acta Geologica Sinica, v. 83, p. 471-478.

Liu, Z., and Dong, X.-P., 2010, The developmental trend of labrum and median eyes of Orsten-type preserved Phosphatocopina (Crustacea): Science China-Earth Science, v. 53, p. 18-26.

Löfgren, A., 1996, Lower Ordovician conodonts, reworking, and biostratigraphy of the Orrebolmen quarry, Västergötland, south-central Sweden: Geologiska Föreningen i Stockolm Förhandlingar, v. 118, p. 169-183.

Lu, Y.-H., 1956, Late Cambrian trilobites from Yuping, Eastern Guizhou: Acta Palaeontologica Sinica, v. 4, p. 365-380. [in Chinese with English abstract]

Miller, J.F., 1969, Conodont fauna of the Notch Peak Limestone (CambroOrdovician), House Range, Utah: Journal of Paleontology, v. 43, p. 413-439.

Miller, J.F., 1970, Conodont evolution and biostratigraphy of the Upper Cambrian and lowest Ordovician [Ph.D. thesis]: Madison, University of Wisconsin-Madison, $137 \mathrm{p}$.

Miller, J.F., 1980, Taxonomic revisions of some Upper Cambrian and Lower Ordovician conodonts with comments on their evolution: The University of Kansas Paleontological Contributions, v. 99, p. 1-39.

Miller, J.F., 1981, Paleozoogeography and biostratigraphy of Upper Cambrian and Tremadocian conodonts, in Taylor, M.E., ed., Short Papers for the Second International Symposium on the Cambrian System: U. S. Geological Survey, Open-File Report 81-743, p. 134-137.

Miller, J.F., 1984, Cambrian and earliest Ordovician conodont evolution, biofacies, and provincialism, in Clark, D.L., ed., Conodont Biofacies and Provincialism: Geological Society of America Special Paper 196, p. 34-68.

Miller, J.F., 1987, Upper Cambrian and basal Ordovician conodont faunas of the southwest flank of the Llano uplift, Texas, in Grayson, R.C.J., ed., Early and Late Paleozoic Conodont Faunas of the Llbno Uplift Region, Central TexasBiostratigraphy, Systemic Boundary Relationship, and Stratigraphic Importance: Guidebook for Field Trip 1, South-Central Section of Geological Society of America/Pander Society, p. 1-22.

Miller, J.F., 1988, Conodont as biostratigraphic tools for redefinition and correlation of the Cambrian-Ordovician boundary: Geological Magazine, v. 125, p. $349-362$.

Miller, J.F., and Stitt, J.H., 1995, Stratigraphic position and significance of Jujiuaspis and Iapetoganthus in the Wilberns Formation, Texas, in Cooper, J.D., ed., Ordovician Odyssey: Short Papers for the Seventh International Symposium on the Ordovician System: Pacific Section of Society for Sedimentary Geology (SEPM), Book 77, p. 105-108.
Miller, J.F., and Taylor, M.E., 1995, Biostratigraphic significance of Iapetognathus (Conodonta) and Jujuaspis (Trilobita) in the House Limestone, Ibex Area, Utah, in Cooper, J.D., ed., Ordovician Odyssey: Short Papers for the Seventh International Symposium on the Ordovician System: Pacific Section of Society for Sedimentary Geology (SEPM), Book 77, p. 109-112.

Miller, J.F., Taylor, M.E., Stitt, J.H., Ethington, R.L., Hintze, L.F., and Taylor, J.F., 1982, Potential Cambrian-Ordovician boundary stratotype sections in western United States, in Bassett, M.G., and Dean, W.T., eds., The Cambrian-Ordovician boundary: sections, fossil distribution, and correlations: National Museum of Wales Geological Series 3, p. 155-180.

Miller, J.F., Evens, K.R., Loch, J.D., Ethington, R.L., Stitt, J.H., Holmer, L., and Popov, L.E., 2003, Stratigraphy of the Sauk III Interval (CambrianOrdovician) in the Ibex Area, Western Millard County, Utah and Central Texas: BYU Geology Studies 2003, v. 47, p. 23-118.

Miller, J.F., Ethington, R.L., Evans, K.R., Holmer, L.E., Loch, J.D., Popov, L.E., Repetski, J.E., Ripperdan, R.L., and Taylor, J.F., 2006, Proposed stratotype for the base of the highest Cambrian stage at the first appearance datum of Cordylodus andresi, Lawson Cove section, Utah, USA: Paleoworld, v. 15, p. 384-405.

Miller, J.F., Evens, K.R., Freeman, R.L., Ripperdan, R.L., and Taylor, J.F., 2011, Proposed stratotype for the base of the Lawsonian Stage (Cambrian Stage 10) at the first appearance datum of Eoconodontus notchpeakensis (Miller) in the House Range, Utah, USA: Bulletin of Geosciences, v. 86, p. 595-620.

Miller, J.F., Evens, K.R., Freeman, R.L., Ripperdan, R.L., and Taylor, J.F., 2014a, The proposed GSSP for the base of Cambrian Stage 10 at the First Appearance Datum of the conodont Eoconodontus notchpeakensis (Miller, 1969) in the House Range, Utah, USA: GFF, v. 136, p. 189-192.

Miller, J.F., Repetski, J.E., Nicoll, R.S., Nowlan, G., and Ethington, R.L., 2014b, The conodont Iapetognathus and its value for defining the base of the Ordovician System: GFF, v. 136, p. 185-188.

Miller, R.H., and Paden, E.A., 1976, Upper Cambrian stratigraphy and conodonts from Eastern California: Journal of Paleontology, v. 50, p. 590-597.

Miller, R.H., Sundberg, F.A., Harma, R.H., and Wright, J., 1981, Late Cambrian stratigraphy and conodonts of southern Nevada: Alcheringa, v. 5, p. 183-197.

Müller, K.J., 1959, Kambrische Conodonten: Zeitschrift der Deutschen Geologischen Gesellschschaft, v. 111, p. 434-485.

Müller, K.J., 1962, Supplement to systematics of conodonts, in Moore, R.C., ed., Treatise on Invertebrate Paleontology, Part W, Miscellanea: New York, Lawrence, Kansas, Geological Society of America and University of Kansas, p. W246-W249.

Müller, K.J., 1971, Cambrian conodont faunas: Geological Society of America Memoir, v. 127, p. 5-20.

Müller, K.J., 1973, Late Cambrian and Early Ordovician conodonts from northern Iran: Geological Survey of Iran, Report 30, p. 1-77.

Müller, K.J., and Hinz, I., 1991, Upper Cambrian conodonts from Sweden: Fossils and Strata, v. 28, p. 1-153.

Müller, K.J., and Hinz, I., 1998, Internal structure of Cambrian conodonts: Journal of Paleontology, v. 72, p. 91-112.

Müller, K.J., and Nogami, Y., 1971, Über den Feinbau der Conodonten: Memoirs of the Faculty of Sciences, University of Kyoto, Series of Geology and Mineralogy, v. 38, p. $1-87$.

Müller, K.J., and Nogami, Y., 1972, Growth and function of conodonts: 24th International Geological Congress, Abstracts Section, v. 7, p. 20-27.

Murdock, D.J.E., Dong, X.-P., Repetski, J.E., Marone, F., Stampanon, M., and Donoghue, P.C.J., 2013, The origin of conodonts and of vertebrate mineralized skeletons: Nature, v. 502, p. 546-549.

Nicoll, R.S., 1990, The genus Cordylodus and a latest Cambrian-earliest Ordovician biostratigraphy: BMR Journal of Australia Geology \& Geophysics, v. 11, p. 529-558.

Nicoll, R.S., 1991, Differentiation of Late Cambrian-Early Ordovician species Cordylodus (Conodonta) with biapical basal cavities: BMR Journal of Australia Geology \& Geophysics, v. 12, p. 223-244.

Nicoll, R.S., and Shergold, J.H., 1991, Revised Late Cambrian (pre-PayntonianDatsonian) conodont biostratigraphy at Black Mountain, Georgina Basin, western Queensland, Australia: BMR Journal of Australia Geology \& Geophysics, v. 12, p. 93-118.

Nicoll, R.S., Miller, J.F., Nowlan, G.S., Repetski, J.E., and Ethington, R.L., 1999, Iapetonudus (n. gen.) and Iapetognathus Landing, unusual earliest Ordovician multielement conodont taxa and their utility for biostratigraphy: Brigham Young University Geology Studies, v. 44, p. 27-101.

Nogami, Y., 1966, Cambrian conodonten von China, Teil 1 Conodonten aus den oberkambrischen Kushan-schichten: Memoirs of College of Science, University of Kyoto, Sereis B, v. 32, p. 351-367.

Nogami, Y., 1967, Cambrian conodonten von China, Teil 2 Conodonten aus den hoch oberkambrischen Yencho-schichten: Memoirs of College of Science, University of Kyoto, Sereis B, v. 33, p. 211-219.

Nowlan, G.S., 1985, Late Cambrian and Early Ordovician conodonts from Franklinian Miogeosyncline, Canadian Arctic Island: Journal of Paleontology, v. 59, p. 96-122. 
Nowlan, G.S., and Nicoll, R.S., 1995, Re-examination of the conodont biostratigraphy at the Cambrian-Ordovician Xiaoyangqiao section, Dayangcha, Jilin Province, China, in Cooper, J.D., ed., Ordovician Odyssey: Short Papers for the Seventh International Symposium on the Ordovician System: Pacific Section of Society for Sedimentary Geology (SEPM), Book 77, p. 113-116.

Olgun, O., 1987, Komponenten-Analyse und Conodonten-Stratigraphie der Orthoceraten-kalksteine in Gebiet Falbygden, Västergöland, Mitteschweden: Sveriges geologiska undersöning, Ca 70, 79 p.

Ortega, G., and Albanesi, G.L., 2005, Tremadocian graptolite-conodont biostratigraphy of the South American Gondwana margin (Eastern Cordillera, NW Argentina): Geologica Acta, v. 3, p. 355-371.

Özgül, N., and Gedik, I., 1973, New data on the stratigraphy and the conodonts faunas of Caltepe Limestone and Seydischir Formation, Lower Paleozoic of Central Taurus Range: Turkish Geological Association Bulletin, v. 16, p. $39-52$.

Pander, C.H., 1856, Monographie der fossilen Fische des Silurischen Systtems der Russisch-Baltischen Governements: Königlische Akademie Wissenschaften, St Petersburg, 91 p.

Parsons, B.P., and Clark, D.L., 1999, Conodonts and the Cambrian-Ordovician boundary in Wisconsin: Geoscience Wisconsin, v. 17, p. 1-10.

Peng, S.-C., 1987, Early Late Cambrian stratigraphy and trilobite fauna of Taoyuan and Cili, Hunan, in Nanjing Institute of Geology and Palaeontology, Academia Sinica, ed., Collections of Postgraduate Theses No. 1: Nanjing, Jiangsu Science and Technology Publishing House, p. 53-134. [in Chinese with English abstract]

Peng, S.-C., 1992, Upper Cambrian biostratigraphy and trilobite faunas of the Cili-Taoyuan area, northwestern Hunan, China: Memoirs of the Association of Australiasian Palaeontologists, v. 13, p. 1-119.

Peng, S.-C., 2009a, Review on the studies of Cambrian trilobite faunas from Jiangnan slope belt, South China, with notes on Cambrian correlations between South and North China: Acta Palaeontologica Sinica, v. 48, p. 437-452.

Peng, S.-C., 2009b, The newly-developed Cambrian biostratigraphic succession and chronostratigraphic scheme for South China: Chinese Science Bulletin, v. 54, p. 4161-4170.

Peng, F., and Dong, X.-P., 2008, Application of synchrotron X-ray tomography microscopy in the research of fossil embryo Markuelia: Acta Scientiarum Naturalium Universitatis Pekinensis, v. 44, p. 447-451. [in Chinese]

Peng, S.-C., and Robison, R.A., 2000, Agnostid biostratigraphy across the Middle-Upper Cambrian boundary in Northwestern Hunan, China: Paleontological Society Memoir, v. 53, p. 1-104.

Peng, S.-C., Babcock, L.E., Robison, R.A., Lin, H.-L., Rees, M.N., and Saltzman, M.R., 2004, Global Standard Stratotype-section and Point (GSSP) of the Furongian Series and Paibi Stage (Cambrian): Lethaia, v. 37, p. 365-379

Peng, S.-C., Babcock, L.E., and Cooper, R.A., 2012, The Cambrian Period, in Gradsten, F.M., Ogg, G., Schmitz, M., and Ogg, G.J., eds., The Geologic Time Scale 2012: Boston, Elsevier, p. 451-502.

Poulsen, V., 1966, Early Cambrian distacodontid conodonts from Bornholm. Biologiske Meddelelser: Der Konggelige Danske Videnskabernes Selskab, v. 23 , p. $1-9$.

Purnell, M.A., Aldridge, R.J., Donoghue, P.C.J., and Gabbot, S.E., 1995, Conodonts and the first vertebrates: Endeavour, New Series, v. 19, p. $20-27$.

Pyle, L.J., and Barnes, C.R., 2001, Conodonts from the Kechika Formation and Road River Group (Lower to Upper Ordovician) of the Cassiar Terrane, northern British Columbia: Canadian Journal of Earth Sciences, v. 38, p. $1387-1401$

Pyle, L.J., and Barnes, C.R., 2002, Taxonomy, Evolution, and Biostratigraphy of the Kechika Formation, and Road River Group (Upper Cambrian to Lower Silurian), Northeastern British Columbia: NRC Research Press, Ottawa, 227 p.

Pyle, L.J., Barnes, C.R., and Mcanally, L.M., 2007, Conodont biostratigraphy of the latest Cambrian-Early Ordovician upper Mckay Group, southeastern British Columbia: Canadian Journal of Earth Sciences, v. 44, p. 1713-1740.

Qi, Y.-P., Bagnoli, G., and Wang, Z.H., 2006, Cambrian conodonts across the pre-Furongian to Furongian interval in the GSSP section at Paibi, Hunan, South China: Rivista Italiana di Paleontologia e Stratigrafia, v. 112, p. $177-190$.

Rao, R.I., and Tortello, M.F., 1998, Tremadoc conodonts and trilobites from the Cardonal Formation, Inacamayo Creek, Salta Province, northwestern Argentina, in Szaniawski, H., ed., Proceedings of the Sixth European Conodont Symposium (ECOS VI): Palaeontologia Polanica, v. 58, p. $31-45$.

Repetski, J.E., 1982, Conodonts from the El Paso Group (Lower Ordovician) of westernmost Texas and southern New Mexico: New Mexico Bureau of Mining and Mineral Research, Memoir, v. 40, p. 1-117.

Robison, R.A., 1981, Supplement 2, Conodonta, in Moore, R.C., and Teichert, C., eds., Treatise on Inverteberate Paleontology, Part W: Lawrence, Kansas, Geological Society of America and University of Kansas Press, p. W1-W202.
Ross, R.J.J., Hintze, L.F., Ethington, R.L., Miller, J.F., Taylor, M.E., and Repetski, J.E., 1997, The Ibexian, lowermost series in the North American Ordovician: U.S. Geological Survey Professional Paper, v. 1579-A, p. $1-150$.

Shergold, J.H., Nicoll, R.S., Laurie, J.R., and Radke, B.M., 1991, The CambroOrdovician boundary at Black Mountain, western Queensland, Guidebook for Field Excursion 2, Sixth International Symposium on the Ordovician System: Bureau of Mineral Resources, Geology and Geophysics, Record, v. 1991/48, p. $1-50$.

Szaniawski, H., 1971, New species of Upper Cambrian conodonts from Poland: Acta Palaeontologica Polonica, v. 16, p. 401-413.

Szaniawski, H., 1982, Chaetognath grasping spines recognized among Cambrian protoconodonts: Journal of Paleontology, v. 56, p. 806-810.

Szaniawski, H., 2002, New evidence for the protoconodont origin of chaetognaths: Acta Palaeontologica Polonica, v. 47, p. 405-419.

Szaniawski, H., 2005, Cambrian chaetognaths recognized in Burgess Shale fossils: Acta Palaeontologica Polonica, v. 50, p. 1-8.

Szaniawski, H., and Bengtson, S., 1993, Origin of euconodont elements: Journal of Paleontology, v. 67, p. 640-654.

Szaniawski, H., and Bengtson, S., 1998, Late Cambrian euconodonts from Sweden, in Szaniawski, H., ed., Proceedings of the sixth European Conodnt Symposium (ECOS VI): Palaeontologia Polonica, v. 58, p. 7-29.

Taylor, M.E., and Landing, E., 1982, Biostratigraphy of the Cambrian-Ordovician transition in the Bear River Range, Utah and Idaho, western United States, in Bassett, M.G., and Dean, W.T., eds., The Cambrian-Ordovician boundary: sections, fossil distribution, and correlations: National Museum of Wales Geological Series 3, p. 181-191.

Taylor, J.F., and Repetski, J.E., 1995, High-resolution trilobite and conodont biostrtigraphy across the Cambriam-Ordovician boundary in south-central New Mexico, in Cooper, J.D., ed., Ordovician Odyssey: Short Papers for the Seventh International Symposium on the Ordovician System: Pacific Section of Society for Sedimentary Geology (SEPM), Book 77, p. 133-136.

Terfelt, F., Bagnoli, G., and Stouge, S., 2012, Re-evaluation of the conodont Iapetognatus and implications for the Ordovician System GSSP: Lethaia, v. 45, p. $227-237$.

Tipnis, R.S., Chatterton, B.D.E., and Ludvigsen, R., 1978, Ordovician conodont biostratigraphy of the southern district of Mackenzie, Canada, in Stelck, C.R., and Chatterton, B.D.E., eds., Western and Arctic Canadian Biostratigraphy: Geological Association of Canada, Special Paper 18, p. 39-91.

Tullberg, S.A., 1880, Om Agnostus-arterna i de Kambriska afaringarne vid Andarum: Sveriges Geologiska Undersökning, Series C, v. 42, p. 1-37.

van Wamel, V.A., 1974, Conodont biostratigraphy of the Upper Cambrian and Lower Ordovician of northwestern Oland, southeastern Sweden: Utrecht Micropaleontological Bulletin, v. 10, p. 1-126.

Viira, V., Sergeeva, S., and Popovu, L., 1987, Samye rannie predstaviteili roda Cordylodus (Conodonta) iz severnoj Ehstonii i Leningradskoj Oblasti [Earliest representatives of the genus Cordylodus (Conodonta) from Cambro-Ordovician boundary beds of North Estonia and Leningrad Region]: Proceedings of the Academy of sciences of Estonian SSSR, Geology, v. 36, p. 145-153.

Wang, Z.-H., 1985, Late Cambrian and Early Ordovician conodonts from North and Northeast China with comments on the Cambrian-Ordovician boundary, in Nanjing Institute of Geology and Palaeontology, Academia Sinica, comp, Stratigraphy and Paleontology of Systemic Boundaries in China, Cambrian-Ordovician Boundary: Ho-fei shih, Anhui Science and Technology Publishing House, p. 195-238.

Wang, Z.-H., and Luo, K.-Q., 1984, Late Cambrian and Ordovician conodonts from the marginal area of the Ordos platform, China: Bulletin of Nanjing Institute of Geology and Palaeontology, Chinese Academy of Sciences, v. 8 , p. $237-304$

Wright, A.J., and Cooper, R.A., 1994, Cambrian and Ordovician faunas and stratigraphy, Mt Patriarch, New Zealand: New Zealand Journal of Geology and Geophysics, v. 37, p. 437-476.

Wu, G.-C., and Dong, X.-P., 2004, The histological study of Granatodontus: Acta Scientiarum Naturalium Universitatis Pekinensis, v. 40, p. 228-231.

Yang, J.-L., 1978, Middle and Upper Cambrian trilobites of Western Hunan and Eastern Guizhou Region: Professional Papers of Stratigraphy and Paleontology, v. 4, p. 1-82. [in Chinese with English abstract]

Yang, J.-L., 1981, The Cambrian System of Jiangnan Region, in Xiang, L.-W., and 11 others eds., The Cambrian System of China: Beijing, Geological Publishing House, p. 56-135. [in Chinese]

Yang, J.-L., 1984, The new zonation of trilobites in the Laochatian Formation: Journal of Wuhan College of Geology - Earth Science, v. 2, p. 23-31. [in Chinese]

Zhang, H.-Q., and Dong, X.-P., 2009, Two new species of Vestrogothia (Phosphatocopina, Crustacea) of Orsten-type preservation from the Upper Cambrian in western Hunan, South China: Science in China Series D: Earth Science, v. 52, p. 784-796. 
Zhang, H.-Q., Dong, X.-P., and Maas, A., 2011a, Hesslandona angustata (Phosphatocopida, Crustacea) from the Upper Cambrian of western Hunan, South China, with comments on phosphatocopid phylogeny: Neues Jahrbuch für Geologie und Paläontologie, Abhandlungen, v. 259, p. 157-175.

Zhang, H.-Q., Dong, X.-P., and Xiao, S., 2011b, Two species of Hesslandona (Phosphatocopida, Crustacea) from the Upper Cambrian of western Hunan, South China and the phylogeny of Phosphatocopida: Journal of Paleontology, v. 85 , p. $776-793$.

Zhang, H.-Q., Dong, X.-P., and Xiao, S., 2012, Three head-larvae of Hesslandona angustata (Phosphatocopida, Crustacea) from the Upper Cambrian of western Hunan, South China and the phylogeny of Crustacea. Gondwana Research, v. 21, p. 1115-1127.

Zhao, Z.-X., Zhang, G.-Z., and Xiao, J.-A., 2000, Palaeozoic strata and conodonts in Xinjiang: Petroleum Industry Press, Beijing, 340 p. [in Chinese]
Zhu, C.-F., and Dong, X.P., 2004, Affinities and functional morphology of the Middle Cambrian ornamented tubules from West Hunan, China: Progress in Natural Sciences, v. 14, p. 907-911.

Zhu, C.-F., Dong, X.-P., and Chen, M.E., 2003, Chancelloriids from late Middle Cambrian of Huayuan, Hunan, South China: Acta Scientiarum Naturalium Universitatis Pekinensis, v. 39, p. 716-726.

Zhu, C.-F., Li, G.-X., and Dong, X.P., 2004, Ornamented tubes from Middle Cambrian of Huayuan, West Hunan, China: Acta Scientiarum Naturalium Universitatis Pekinensis, v. 40, p. 193-202.

Accepted 1 May 2014 